\title{
EFEITO DE DOENÇAS FOLIARES NA EFICIÊNCIA FOTOSSINTÉTICA DO FEIJOEIRO (Phaseolus vulgaris L.) COMO CONTRIBUIÇÃO NA AVALIAÇÃO DE DANOS
}

\section{RENATO BEOZZo BASSANEZI}

Engenheiro Agrônomo

Orientadora: Prof ${ }^{\mathrm{a}}$. Dr ${ }^{\mathrm{a}}$. LILIAN AMORIM

Tese apresentada à Escola Superior de Agricultura "Luiz de Queiroz", Universidade de São Paulo. para obtenção do título de Doutor em Agronomia, Área de Concentração: Fitopatologia.

\section{PIRACICABA}

Estado de São Paulo - Brasil

Janeiro -2000 
Dados Internacionais de Catalogação na Publicação (CIP) DIVISÃO DE BIBLIOTECA E DOCUMENTAÇÃO - Campus "Luiz de Queiroz"/USP

Bassanezi, Renato Beozzo

Efeito de doenças foliares na eficiência fotossintética do feijoeiro (Phaseo/us vulgaris

L.) como contribuição na avaliação de danos / Renato Beozzo Bassanezi. - 2000.

233 p. : il.

Tese (doutorado) - Escola Superior de Agricultura Luiz de Queiroz, 2000.

Bibliografia.

1. Antracnose-do-feijoeiro 2. Doença de planta 3. Feijāo 4. Ferrugem-do-feijāo 5.

Fotossintese 6. Mancha-angular-do-feijoeiro 7. Relaçāo temperatura-meio-ambiente I.

Titulo

$\operatorname{CDD} 635.652$

"Permitida a copia total ou parcial deste documento, desde que citada a fonte - $\mathrm{O}$ autor" 


\begin{abstract}
Aos meus pais Rodney e Maria Sílvia, meus avós Albino, Isaltina, Izídio e Olivia e minhas irmãs Carla, Betina e Camila, pelos incentivos e apoio, DEDICO.
\end{abstract}

\author{
"Nunca tenha medo \\ de sentar-se um pouco e pensar" \\ (Lorraine Hansberry) \\ "A descoberta consiste em ver o que todos já viram \\ e pensar sobre o que ninguém jamais pensou" \\ (Albert Szent-Györgyi) \\ "Um dia em que você aprende alguma coisa \\ nunca é uma perda total" \\ (David Eddings) \\ "Na história de qualquer problema, \\ há um momento em que ele \\ é suficientemente grande para ser identificado, \\ mas pequeno demais para ser resolvido" \\ (Mike Leavitt)
}

À Celia pela imensa ajuda, paciência, dedicação, amor e companheirismo, OFEREÇO. 


\section{AGRADECIMENTOS}

Agradeço a todos que contribuíram de alguma forma para a realização deste trabalho, colegas, professores e funcionários do Setor de Fitopatologia do Departamento de Entomologia, Fitopatologia e Zoologia Agrícola da ESALQ/USP, em especial:

À Prof ${ }^{\mathrm{a}}$. Dr ${ }^{\mathrm{a}}$. Lilian Amorim, pela exemplar orientação, auxílio e dedicação, pelo apoio racional e emocional em todos momentos e pela amizade nesta longa caminhada desde a Iniciação Científica em 1990.

Ao Prof. Dr. Armando Bergamin Filho pelas idéias, sugestões, visão holística e facilidades logísticas para o desenvolvimento dos trabalhos em epidemiologia.

Aos professores e pesquisadores estrangeiros Bernhard Hau (Hannover Universitat), Bernard Genty (Université de Paris-Sud XI) e Richard D. Berger (University of Florida) que me receberam em seus laboratórios para experimentação, treinamento, discussão e análise de dados.

Aos demais professores do Setor de Fitopatologia do Departamento de Entomologia, Fitopatologia e Zoologia Agrícola da ESALQ/USP pelos ensinamentos e contribuições fornecidas à minha vida acadêmica e profissional.

Ao Sr. Pedro Arthuso, Robson, Renata, Nilceli, Cássia e Sílvia pelo auxílio na instalação e avaliação dos experimentos de campo, preparo de meio de cultura e repicagem dos fungos para o preparo de inóculo.

Aos colegas epidemiologistas Marilene T. Iamauti, Cláudia V. Godoy, Solange M. T. P. G. Carneiro e Leonardo Gianasi por concederem seus dados experimentais para o desfecho deste trabalho.

À Coordenação de Aperfeiçoamento de Pessoal de Nível Superior (CAPES) pelo auxílio financeiro no primeiro ano do curso de pós-graduação.

À Fundação de Amparo à Pesquisa do Estado de São Paulo (FAPESP) pela bolsa de estudo e reserva técnica concedida para a realização desta pesquisa nos 3 anos restantes do curso de pós-graduação. 


\section{SUMÁRIO}

Página

LISTA DE FIGURAS ......................................................................... vii

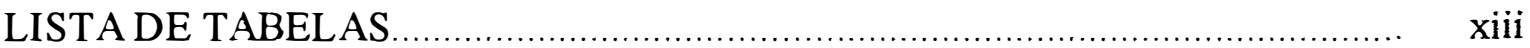

RESUMO

SUMMARY.

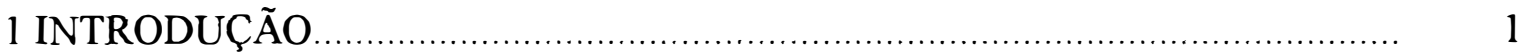

2 REVISÃO DE LITERATURA. ....................................................... 3

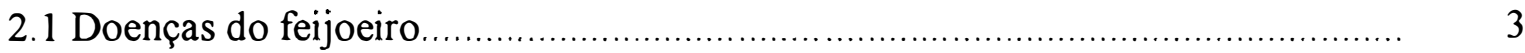

2.1.1 Importância da cultura e das doenças do feijoeiro.................................... 3

2.1.2 Antracnose do feijoeiro.............................................................. 4

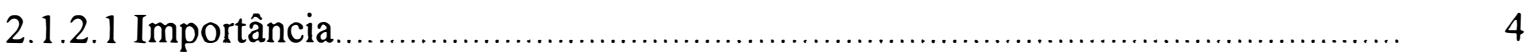

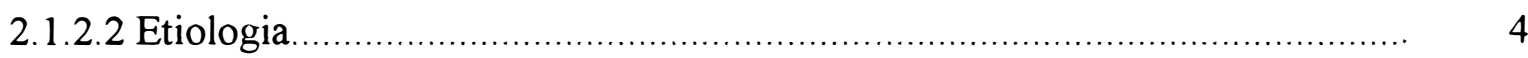

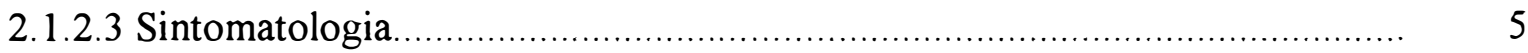

2.1.2.4 Fatores ambientais que interferem no desenvolvimento da doença.............. 6

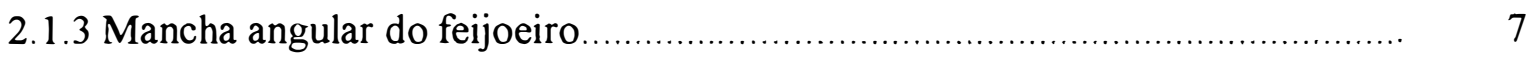

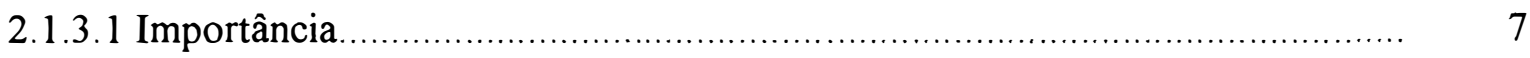

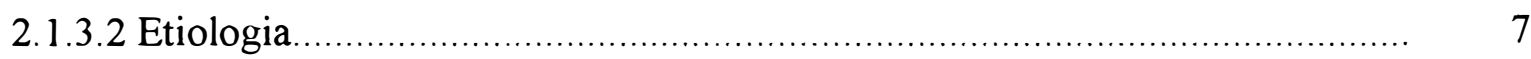

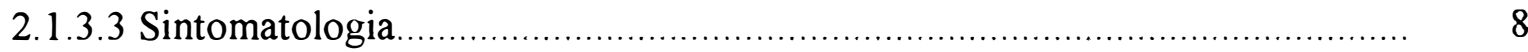

2.1.3.4 Fatores ambientais que interferem no desenvolvimento da doença............. 9

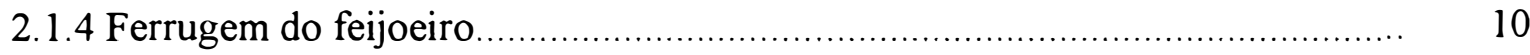

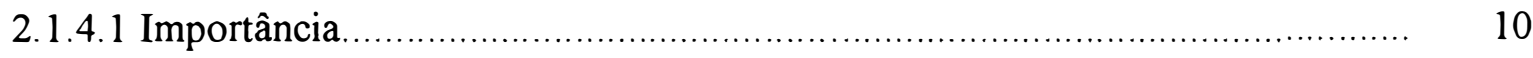

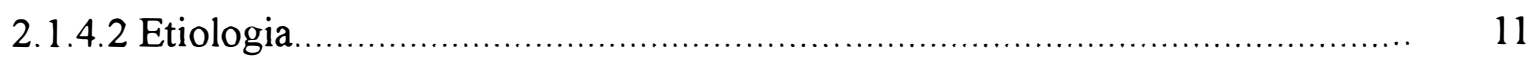

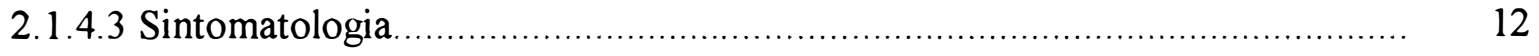

2.1.4.4 Fatores ambientais que interferem no desenvolvimento da doença............. 13

2.2 Doenças como fator de estresse e seu efeito em processos fisiológicos do

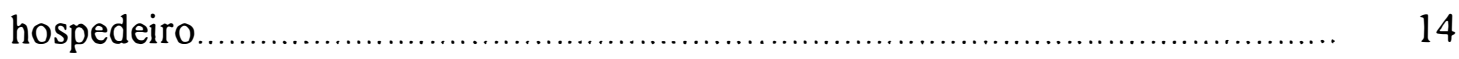

2.2.1 Alterações na fotossíntese de plantas doentes......................................... 15

2.2.1.1 Fungos hemibiotróficos e necrotróficos ......................................... 16 


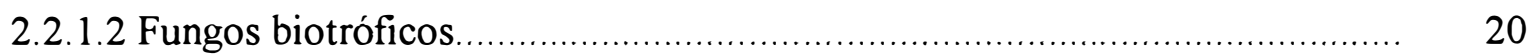

2.2.2 Alterações na respiração de plantas doentes................................................. 24

2.2.3 Alterações na transpiração e condutância estomática de plantas doentes......... 26

2.2.4 Avaliação da fotossíntese, respiração, transpiração e condutância estomática

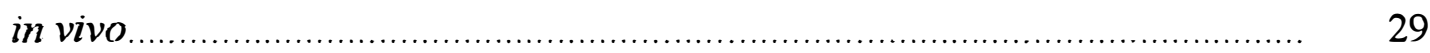

2.2.4.1 Sistema de trocas gasosas.................................................................. 30

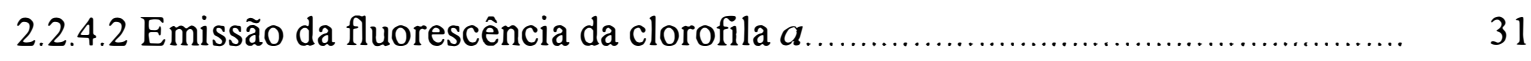

2.3 Avaliação de danos e eficiência fotossíntetica de plantas doentes ...................... 34

3 ALTERAÇÕES NA FOTOSSÍNTESE, RESPIRAÇÃO E TRANSPIRAÇÃO DAS FOLHAS DE FEIJOEIRO INFECTADAS COM Uromyces appendiculatus, Phaeoisariopsis griseola E Colletotrichum lindemuthianum DURANTE O DESENVOLVIMENTO DAS DOENÇAS................................. 39

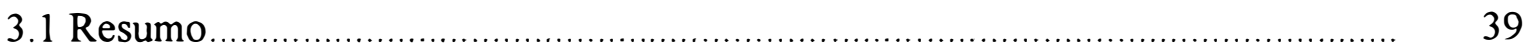

3.2 Introdução

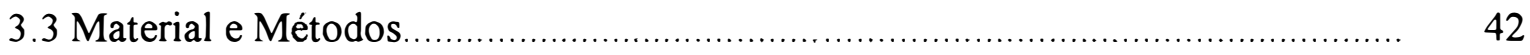

3.3.1 Material vegetal e preparo das plantas....................................................... 42

3.3.2 Obtenção e preparo de inóculo................................................................ 43

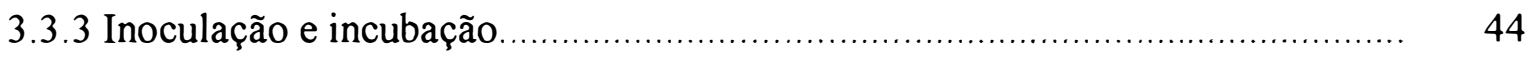

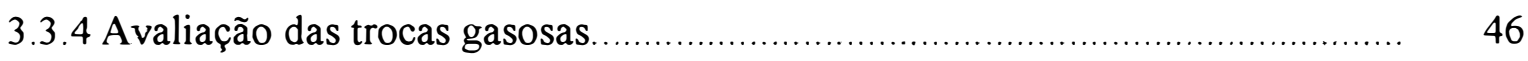

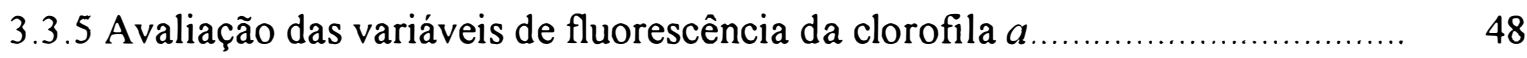

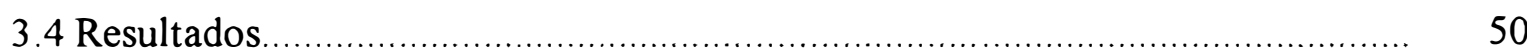

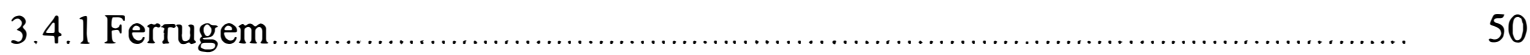

3.4.1.1 Progresso da doença ....................................................................... 50

3.4.1.2 Variáveis relacionadas com as trocas gasosas.......................................... 51

3.4.1.3 Variáveis relacionadas com a emissão de fluorescência da clorofila $a \ldots \ldots \ldots . . .58$

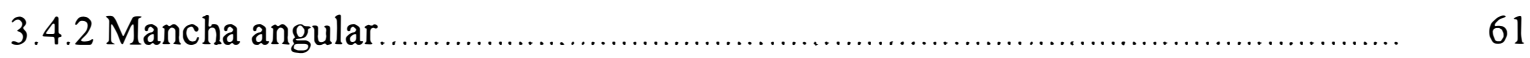

3.4.2.1 Progresso da doença ........................................................................... 61

3.4.2.2 Variáveis relacionadas com as trocas gasosas ......................................... 61

3.4.2.3 Variáveis relacionadas com a emissão de fluorescência da clorofila $a$......... 69

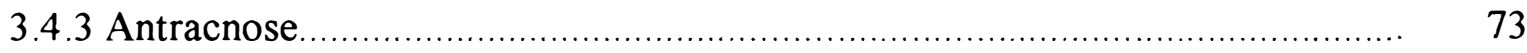


3.4.3.1 Progresso da doença

3.4.3.2 Variáveis relacionadas com as trocas gasosas............................................. 79

3.4.3.3 Variáveis relacionadas com a emissão de fluorescência da clorofila $a \ldots \ldots . . . . .80$

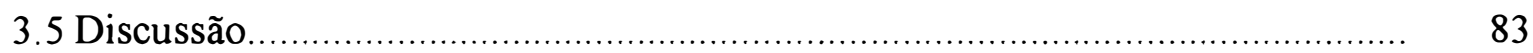

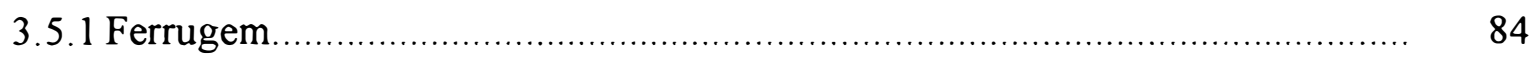

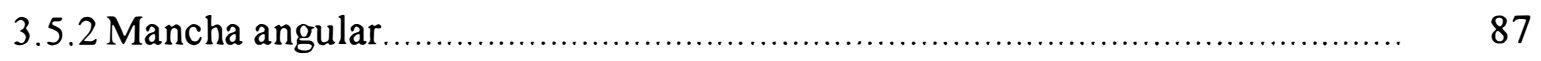

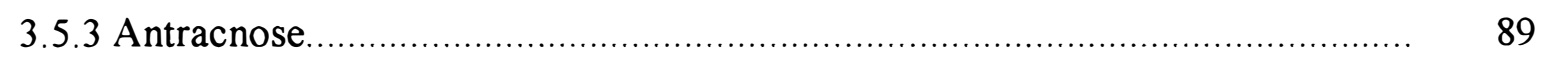

4 ANÁlISE DA FOTOSSÍNTESE PELAS CURVAS DA ASSIMILAÇÃO LÍQUIDA DE $\mathrm{CO}_{2}$ PELA CONCENTRAÇÃO INTERCELULAR DE $\mathrm{CO}_{2}$ $(\mathrm{A} / \mathrm{C} i)$ EM FOLHAS DE FEIJOEIRO INFECTADAS COM FERRUGEM, MANCHA ANGULAR E ANTRACNOSE .................................................... 92

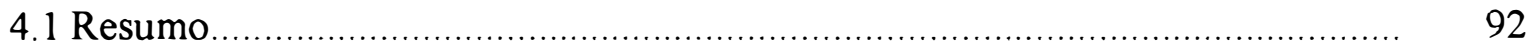

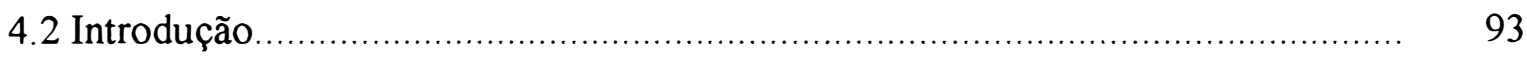

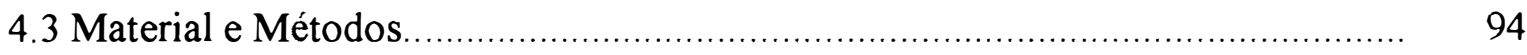

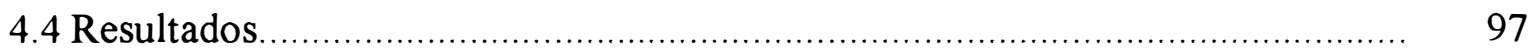

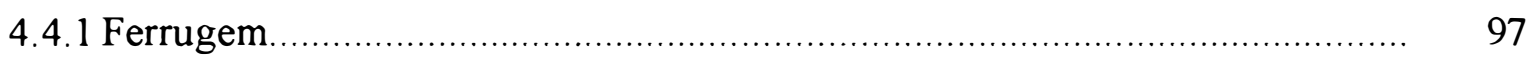

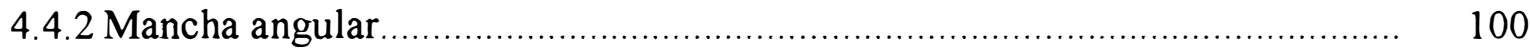

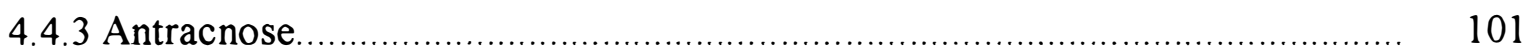

4.4.4 Comparação das cultivares de feijoeiro ..................................................... 102

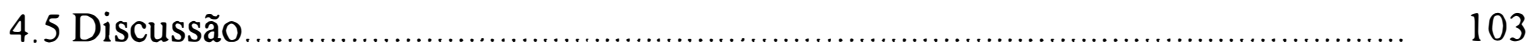

5 EFICIÊNCIA FOTOSSINTÉTICA DA ÁREA VERDE REMANESCENTE DE FOLHAS DE FEIJOEIRO COM FERRUGEM, MANCHA ANGULAR OU

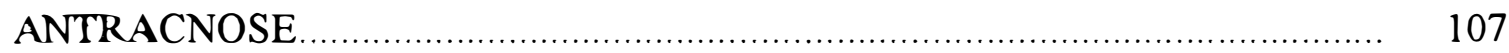

5.1 Resumo

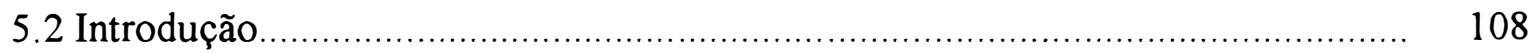

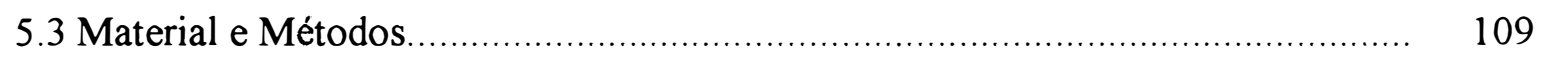

5.3.1 Experimentos em câmaras de crescimento .............................................. 109

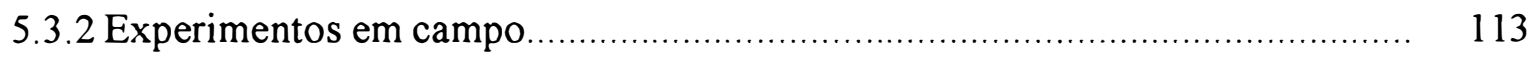

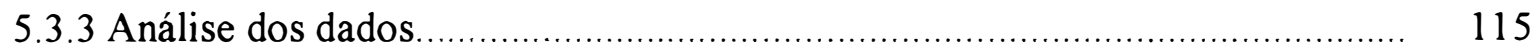

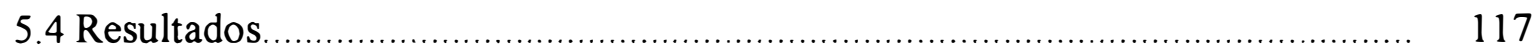


5.4.1 Experimentos em câmaras de crescimento.

5.4.2 Experimentos em campo.

5.5 Discussão

6 INCORPORAÇÃO DOS EFEITOS DA FERRUGEM, MANCHA ANGULAR E ANTRACNOSE NA EFICIÊNCIA FOTOSSINTÉTICA DE FOLHAS DOENTES DE FEIJOEIRO EM MODELOS DE AVALIAÇÃO DE DANOS....

6. 1 Resumo 136

6.2 Introdução. 137

6.3 Material e Métodos. 138

6.4 Resultados 142

6.5 Discussão 147 7 CONCLUSÕES. 151

REFERÊNCIAS BIBLIOGRÁFICAS 


\section{LISTA DE FIGURAS}

Página

\section{ALTERAÇÕES NA FOTOSSÍNTESE, RESPIRAÇÃO E TRANSPIRAÇÃO DAS FOLHAS DE FEIJOEIRO INFECTADAS} COM Uromyces appendiculatus, Phaeoisariopsis griseola E Colletotrichum lindemuthianum DURANTE O DESENVOLVIMENTO DAS DOENÇAS.

01 Etapas para a avaliação da severidade de doenças do feijoeiro por meio da análise de imagens em microcomputador pelo programa SIARCS 3.0: (a) seleção da área a ser avaliada; (b) seleção dos pixels correspondentes às lesões; (c) binarização.

02 Estádios de desenvolvimento da ferrugem do feijoeiro: (a) pontuações pequenas e "encharcadas"; (b) "flecks"; (c) início da esporulação nas pústulas; (d) esporulação em $100 \%$ das pústulas.

03 Valor médio (símbolo) e erro padrão (barra) da: (a) severidade de ferrugem (\%), (b) taxa de assimilação líquida de $\mathrm{CO}_{2}$ (\% do controle) e (c) taxa de respiração no escuro (\% do controle) de folhas doentes da cv. Rosinha G-2 crescidas em diferentes temperaturas após a inoculação.

04 Valor médio (símbolo) e erro padrão (barra) da: (a) condutância estomática, (b) taxa de transpiração e (c) concentração intercelular de $\mathrm{CO}_{2}$ de folhas com ferrugem da cv. Rosinha G-2 crescidas em diferentes temperaturas após a inoculação (valores em \% do controle)

05 Valor médio (símbolo) e erro padrão (barra) da: (a) severidade de ferrugem (\%), (b) taxa de assimilação líquida de $\mathrm{CO}_{2}$ (\% do controle) e (c) taxa de respiração no escuro (\% do controle) de folhas doentes da cv. Carioca Comum crescidas em diferentes temperaturas após a inoculação.

06 Valor médio (símbolo) e erro padrão (barra) da: (a) condutância estomática, (b) taxa de transpiração e (c) concentração intercelular de $\mathrm{CO}_{2}$ de folhas com ferrugem da cv. Carioca Comum crescidas em diferentes temperaturas após a 
inoculação (valores em \% do controle)

07 Valor médio (símbolo) e erro padrão (barra) da severidade de ferrugem (\%), fluorescência mínima $\left(F_{0}\right)$, fluorescência máxima $\left(F_{\mathrm{m}}\right)$ e máxima eficiência quântica do fotossistema II $\left(F_{\mathrm{v}} / F_{\mathrm{m}}\right)$ de regiões aparentemente sadias de folíolos doentes $(O)$ e regiões sintomáticas de folíolos doentes $(\mathbf{O}) \mathrm{da} \mathrm{cv}$. Rosinha G-2 crescidos a 23,19 e $15^{\circ} \mathrm{C}$ após a inoculação (as variáveis de fluorescência estão apresentadas em \% do controle)

08 Valor médio (símbolo) e erro padrão (barra) da severidade de ferrugem (\%), fluorescência mínima $\left(F_{0}\right)$, fluorescência máxima $\left(F_{\mathrm{m}}\right)$ e máxima eficiência quântica do fotossistema II $\left(F_{\mathrm{v}} / F_{\mathrm{m}}\right)$ de regiões aparentemente sadias de folíolos doentes $(\mathrm{O})$ e regiões sintomáticas de folíolos doentes $(\boldsymbol{O}) \mathrm{da} \mathrm{cV}$. Carioca Comum crescidos a 23,19 e $15^{\circ} \mathrm{C}$ após a inoculação (as variáveis de fluorescência estão apresentadas em \% do controle)

09 Estádios de desenvolvimento da mancha angular do feijoeiro: (a) pontuações pequenas e "encharcadas"; (b) pequenas manchas necróticas; (c) manchas angulares necróticas; (d) manchas angulares necróticas e início do amarelecimento entre as manchas; (e) manchas angulares necróticas e amarelecimento entre as manchas; ( $f$ ) amarelecimento e seca da folha.

10 Valor médio (símbolo) e erro padrão (barra) da: (a) severidade de mancha angular (\%), (b) taxa de assimilação líquida de $\mathrm{CO}_{2}(\%$ do controle) e (c) taxa de respiração no escuro (\% do controle) de folhas doentes da cv. Rosinha G-2 crescidas em diferentes temperaturas após a inoculação

11 Valor médio (símbolo) e erro padrão (barra) da: (a) condutância estomática, (b) taxa de transpiração e (c) concentração intercelular de $\mathrm{CO}_{2}$ de folhas com mancha angular da cv. Rosinha G-2 crescidas em diferentes temperaturas após a inoculação (valores em \% do controle)

12 Valor médio (símbolo) e erro padrão (barra) da: (a) severidade de mancha angular (\%), (b) taxa de assimilação líquida de $\mathrm{CO}_{2}$ (\% do controle) e (c) taxa de respiração no escuro (\% do controle) de folhas doentes da cv. 
Carioca Comum crescidas em diferentes temperaturas após a inoculação.

13 Valor médio (símbolo) e erro padrão (barra) da: (a) condutância estomática, (b) taxa de transpiração e (c) concentração intercelular de $\mathrm{CO}_{2}$ de folhas com mancha angular da cv. Carioca Comum crescidas em diferentes temperaturas após a inoculação (valores em \% do controle).

14 Valor médio (símbolo) e erro padrão (barra) da severidade de mancha angular $(\%)$, fluorescência mínima $\left(F_{0}\right)$, fluorescência máxima $\left(F_{\mathrm{m}}\right)$ e máxima eficiência quântica do fotossistema II $\left(F_{\mathrm{v}} / F_{\mathrm{m}}\right)$ de regiões aparentemente sadias de folíolos doentes $(O)$ e regiões sintomáticas de folíolos doentes (O) da cv. Rosinha G-2 crescidos a 25, 22 e $19{ }^{\circ} \mathrm{C}$ após a inoculação (as variáveis de fluorescência estão apresentadas em \% do controle).

15 Valor médio (símbolo) e erro padrão (barra) da severidade de mancha angular $(\%)$, fluorescência mínima $\left(F_{0}\right)$, fluorescência máxima $\left(F_{\mathrm{m}}\right)$ e máxima eficiência quântica do fotossistema II $\left(F_{\mathrm{v}} / F_{\mathrm{m}}\right)$ de regiões aparentemente sadias de folíolos doentes $(O)$ e regiões sintomáticas de folíolos doentes (O) da cv. Carioca Comum crescidos a 25,22 e $19^{\circ} \mathrm{C}$ após a inoculação (as variáveis de fluorescência estão apresentadas em \% do controle)

16 Fluorescência mínima $\left(F_{0}\right)$, fluorescência máxima $\left(F_{\mathrm{m}}\right)$, máxima eficiência quântica do fotossistema II $\left(F_{\mathrm{v}} / F_{\mathrm{m}}\right)$ em função da severidade de mancha angular.

17 Estádios de desenvolvimento da antracnose do feijoeiro: (a) pequenas lesões pardo-avermelhadas nas nervuras; (b) lesões pardo-avermelhadas nas nervuras; (c) lesões pardo-avermelhadas nas nervuras e áreas "encharcadas" com início de necrose; (d) lesões pardo-avermelhadas nas nervuras e murcha e seca da folha.

18 Valor médio (símbolo) e erro padrão (barra) da: (a) severidade de antracnose (\%), (b) taxa de assimilação líquida de $\mathrm{CO}_{2}$ (\% do controle) e (c) taxa de 
respiração no escuro (\% do controle) de folhas doentes da cv. Rosinha G-2 crescidas em diferentes temperaturas após a inoculação

19 Valor médio (símbolo) e erro padrão (barra) da: (a) condutância estomática, (b) taxa de transpiração e (c) concentração intercelular de $\mathrm{CO}_{2}$ de folhas com antracnose da cv. Rosinha G-2 crescidas em diferentes temperaturas após a inoculação (valores em \% do controle).

20 Valor médio (símbolo) e erro padrão (barra) da: (a) severidade de antracnose (\%), (b) taxa de assimilação líquida de $\mathrm{CO}_{2}$ (\% do controle) e (c) taxa de respiração no escuro (\% do controle) de folhas doentes da cv. Carioca Comum crescidas em diferentes temperaturas após a inoculação.

21 Valor médio (símbolo) e erro padrão (barra) da: (a) condutância estomática, (b) taxa de transpiração e (c) concentração intercelular de $\mathrm{CO}_{2}$ de folhas com antracnose da cv. Carioca Comum crescidas em diferentes temperaturas após a inoculação (valores em \% do controle)

22 Fluorescência mínima $\left(F_{0}\right)$, fluorescência máxima $\left(F_{\mathrm{m}}\right)$ e máxima eficiência quântica do fotossistema II $\left(F_{\mathrm{v}} / F_{\mathrm{m}}\right)$ em função da severidade de antracnose (\%) nos folíolos da primeira folha trifoliolada da cv. Rosinha G-2 (a) e Carioca Comum (b) crescidos a $19^{\circ} \mathrm{C}$ após a inoculação

4 ANÁlise DA FOtOSSÍNTESE PELAS CURVAS DA ASSIMLAÇÃO LÍQUIDA DE $\mathrm{CO}_{2}$ PELA CONCENTRAÇÃO INTERCELULAR DE $\mathrm{CO}_{2}(A / C i)$ EM FOLHAS DE FEIJOEIRO INFECTADAS COM FERRUGEM, MANCHA ANGULAR E ANTRACNOSE.

01 Exemplo de uma curva de resposta $A / C i$ mostrando a porção da curva usada para determinar a atividade da Rubisco e os pontos para determinar a limitação estomática da fotossíntese

02 Severidade (\%) na região avaliada, $A C e_{350}\left(\square \mathrm{mol} \mathrm{m}^{-2} \mathrm{~s}^{-1}\right), A R u b\left(\mathrm{~mol} \mathrm{~m}^{-2} \mathrm{~s}\right.$ $\left.{ }^{1}\right), g s_{350}\left(\mathrm{~mol} \mathrm{~m}^{-2} \mathrm{~s}^{-1}\right)$ e $L E F(\%)$ na área verde remanescente das folhas da $\mathrm{cv}$. 
Rosinha G-2 sadia (RS) e doente (RD) e Carioca Comum sadia (CS) e doente (CD) nos dois experimentos com ferrugem, mancha angular $\mathrm{e}$ antracnose (média \pm erro padrão de cinco observações)

5 EFICIÊNCIA FOTOSSINTÉTICA DA ÁREA VERDE REMANESCENTE DE FOLHAS DE FEIJOEIRO COM FERRUGEM, MANCHA ANGULAR OU ANTRACNOSE.................................................

01 Relação entre a taxa fotossintética líquida relativa $\left(P_{\mathrm{x}} / P_{0}\right)$ e a severidade de ferrugem, mancha angular e antracnose em folíolos de feijoeiro 


\section{LISTA DE TABELAS}

Página

3 ALTERAÇÕES NA FOTOSSÍNTESE, RESPIRAÇÃO E TRANSPIRAÇÃO DAS FOLHAS DE FEIJOEIRO INFECTADAS COM Uromyces appendiculatus, Phaeoisariopsis griseola E Colletotrichum lindemuthianum DURANTE O DESENVOLVIMENTO DAS DOENÇAS.

01 Estádios de desenvolvimento da ferrugem e o diâmetro médio das lesões $(\mathrm{mm})$ para cada temperatura em cada dia após a inoculação (dai) em que houve avaliação dos processos fisiológicos

02 Estádios de desenvolvimento da mancha angular e variação no tamanho das lesões $\left(\mathrm{mm}^{2}\right)$ para cada temperatura em cada dia após a inoculação (dai) em que houve avaliação dos processos fisiológicos.

03 Estádios de desenvolvimento da antracnose para cada temperatura em cada dia após a inoculação (dai) em que houve avaliação dos processos fisiológicos

4 ANÁlise DA FOTOSSÍNTESE PELAS CURVAS DA ASSIMILAÇÃO LÍQUIDA DE $\mathrm{CO}_{2}$ PELA CONCENTRAÇÃO INTERCELULAR DE $\mathrm{CO}_{2}(A / C i)$ EM FOLHAS DE FEIJOEIRO INFECTADAS COM FERRUGEM, MANCHA ANGULAR E ANTRACNOSE

01 Efeitos principais dos dados da análise de variância no efeito de Uromyces appendiculatus nas cultivares de feijoeiro nos dois experimentos (médias de 10 observações)

02 Efeitos principais dos dados da análise de variância no efeito de Phaeoisariopsis griseola nas cultivares de feijoeiro nos dois experimentos (médias de 10 observações).

03 Efeitos principais dos dados da análise de variância no efeito de 
Colletotrichum lindemuthianum nas cultivares de feijoeiro nos dois experimentos (médias de 10 observações).

5 EFICÊNCIA FOTOSSINTÉTICA DA ÁREA VERDE REMANESCENTE DE FOLHAS DE FEIJOEIRO COM FERRUGEM, MANCHA ANGULAR OU ANTRACNOSE.

01 Valores de $\beta$ estimados para a ferrugem do feijoeiro em cada experimento, envolvendo as cv. Rosinha G-2 e Carioca Comum em diferentes temperaturas em ${ }^{\circ} \mathrm{C}(\mathrm{T})$ e épocas de avaliação em dias após a inoculação (dai)

02 Valores de $\beta$ estimados para a mancha angular do feijoeiro em cada experimento, envolvendo as cv. Rosinha G-2 e Carioca Comum em diferentes temperaturas em ${ }^{\circ} \mathrm{C}(\mathrm{T})$ e épocas de avaliação em dias após a inoculação (dai).

03 Valores de $\beta$ estimados para a antracnose do feijoeiro em cada experimento envolvendo as cv. Rosinha G-2 e Carioca Comum em diferentes temperaturas em ${ }^{\circ} \mathrm{C}(\mathrm{T})$ e épocas de avaliação em dias após a inoculação (dai)

04 Valores de $\beta$ estimados para a ferrugem, mancha angular e antracnose do feijoeiro em cada temperatura em ${ }^{\circ} \mathrm{C}$ (T) testada dentro da cultivar independentemente da época de avaliação

05 Valores de $\beta$ estimados para a ferrugem, mancha angular e antracnose do feijoeiro em cada estádio fenológico da cultura (EF) avaliado dentro da cultivar.

6 INCORPORAÇÃO DOS EFEITOS DA FERRUGEM, MANCHA ANGULAR E ANTRACNOSE NA EFICIÊNCIA FOTOSSINTÉTICA DE FOLHAS DOENTES DE FEIJOEIRO EM MODELOS DE AVALIAÇÃO DE DANOS.......................................................................... 
01 Doença, código do experimento, cultivar, safra, data de semeadura, local e referência dos experimentos em cujos dados foram incorporados os efeitos das doenças na eficiência fotossintética da área verde remanescente das folhas infectadas.

02 Número de plantas avaliadas ( $n$ ), início da epidemia (dias após o plantio), duração da epidemia (dias), severidade máxima na planta (\%), severidade média nas plantas (\%), $A U D P C$ máxima por dia de epidemia e $A U D P C$ média por dia de epidemia dos experimentos em cujos dados foram incorporados os efeitos das doenças na eficiência fotossintética da área verde remanescente das folhas infectadas.

03 Número de plantas avaliadas (n), dias de avaliação, $A U D P C$ e $A U V D P C$ médias por dia de epidemia, $H A D, P A D, H A A$ e $P A A$ médias por dia de avaliação dos experimentos em cujos dados foram incorporados os efeitos das doenças na eficiência fotossintética da área verde remanescente das folhas infectadas.

04 Ponto de interseção ( \pm erro padrão) e coeficiente angular ( \pm erro padrão) das regressões lineares entre a produção (g/planta) e $A U D P C$ e entre a produção e $A U V D P C$ para plantas de feijoeiro com ferrugem (F), mancha angular (M) ou antracnose (A) em diferentes experimentos

05 Ponto de interseção ( \pm erro padrão) e coeficiente angular ( \pm erro padrão) das regressões lineares entre a produção (g/planta) e $H A D$ (dias) e entre a produção e $P A D$ (dias) para plantas de feijoeiro com ferrugem (F), mancha angular (M) ou antracnose (A) em diferentes experimentos.

06 Ponto de interseção ( \pm erro padrão) e coeficiente angular ( \pm erro padrão) das regressões lineares entre a produção (g/planta) e $H A A\left(\mathrm{MJ} \mathrm{m}^{-2}\right)$ e entre a produção e $P A A\left(\mathrm{MJ} \mathrm{m}^{-2}\right)$ para plantas de feijoeiro com ferrugem $(\mathrm{F})$, mancha angular (M) ou antracnose (A) em diferentes experimentos. 


\title{
EFEITO DE DOENÇAS FOLIARES NA EFICIÊNCIA FOTOSSINTÉTICA DO FEIJOEIRO (Phaseolus vulgaris L.) COMO CONTRIBUIÇÃO NA AVALIAÇÃO DE DANOS
}

\author{
Autor: RENATO BEOZZO BASSANEZI \\ Orientadora: Prof ${ }^{\mathrm{a}}$. Dr ${ }^{\mathrm{a}}$. LILIAN AMORIM
}

\section{RESUMO}

$\mathrm{O}$ efeito da ferrugem, mancha angular e antracnose do feijoeiro nos processos fisiológicos relacionados com a fotosintese de folhas das cultivares Rosinha G-2 e Carioca Comum foi observado por meio de experimentos em condições de ambiente controlado e de campo. Inicialmente, em condição de ambiente controlado, acompanhouse as mudanças provocadas pelos patógenos na fotossintese, respiração, transpiração, condutância estomática e variáveis relacionadas com a emissão de fluorescência da clorofila $a$ de folhas infectadas durante todo processo de desenvolvimento da doença sob diferentes temperaturas e nas duas cultivares. Em seguida, pela análise da curva de resposta da taxa de assimilação de $\mathrm{CO}_{2}$ versus a concentração intercelular de $\mathrm{CO}_{2}(\mathrm{~A} / \mathrm{C} i)$ de folhas doentes com cada patógeno, determinou-se quais foram os fatores responsáveis pela redução da taxa fotossintética líquida nestas folhas doentes. A fotossíntese diminuiu e a respiração aumentou a partir do aparecimento dos sintomas das doenças. A transpiração e a condutância estomática diminuíram com o aumento da severidade de mancha angular e antracnose, mas não nas folhas com ferrugem. Além disso, a taxa fotossintética líquida das folhas de feijoeiro com ferrugem, mancha angular e antracnose foi reduzida também na área foliar remanescente, sendo a resistência à carboxilação o principal fator desta redução nas folhas com ferrugem e com mancha angular e a resistência estomática o principal fator nas folhas com antracnose. 
Posteriormente, relações entre a severidade de cada doença e seu efeito na atividade fotossintética das folhas de feijoeiro doentes foram estabelecidas, aplicando-se $o$ conceito de lesão virtual proposto por Bastiaans (1991), em condições controladas e no campo. Valores de $\beta$ em torno de 2,4 e 8 , respectivamente para ferrugem, mancha angular e antracnose, mostraram-se constantes mesmo quando determinados em diferentes épocas de avaliação após a infecção e estádios fenológicos da cultura, temperaturas de desenvolvimento da doença e duas cultivares de feijoeiro. Estes valores também foram associados aos mecanismos pelos quais os patógenos se relacionam com o hospedeiro e aos diferentes sintomas provocados pelas doenças.

Finalmente, pela incorporação do valor de $\beta$ no cálculo da severidade de doença, a área sob a curva de progresso da doença virtual ( $A U V D P C)$ não mostrou relação com a produção, do mesmo modo que a área sob a curva de progresso da doença (AUDPC). Entretanto, as variáveis que consideram a área fotossinteticamente ativa ( $P A D$ e $P A A)$, explicaram melhor as variações na produção de plantas doentes de feijoeiro quando comparadas com as variáveis que consideram somente a área foliar verde remanescente (HAD e $H A A)$. 


\title{
EFFECT OF FOLIAR DISEASES ON PHOTOSYNTHETIC EFFICIENCY OF COMMON BEAN (Phaseolus vulgaris L.) AS A CONTRIBUTION TO YIELD LOSS ASSESSMENT
}

\author{
Author: RENATO BEOZZO BASSANEZI \\ Adviser: Prof ${ }^{a}$. Dr ${ }^{a}$. LILIAN AMORIM
}

\section{SUMMARY}

The effect of bean rust, angular leaf spot and anthracnose on physiological processes related to the leaf photosynthesis of cultivars Rosinha G-2 and Carioca Comum was observed in several experiments under controlled environment and field conditions. Initially, the changes caused by these diseases on photosynthesis, respiration, transpiration, stomatal conductance, and variables related to the chlorophyll $a$ fluorescence of infected leaves were measured during the disease development at different temperatures and two common bean cultivars under controlled environment conditions. Afterwards, the factors responsible for the reduction of net photosynthetic rate in the diseased leaves were determined by the analysis of the response curves of $\mathrm{CO}_{2}$ assimilation rate versus $\mathrm{CO}_{2}$ intercellular concentration $(\mathrm{A} / \mathrm{C} i)$. Photosynthesis decreased and respiration increased following the appearance of disease symptoms. Both transpiration and stomatal conductance decreased with the increasing severities of angular leaf spot and anthracnose. Transpiration and stomatal conductance did not change in leaves with rust. The net photosynthetic rate of bean leaves with rust, angular leaf spot and anthracnose was reduced in the remaining green leaf area, mainly due to carboxylation resistance in leaves with rust and angular leaf spot and due to stomatal resistance in leaves with anthracnose.

The relationships between the severity of each disease and their effect on photosynthetic activity of diseased bean leaves were established by applying the virtual 
lesion concept proposed by Bastiaans (1991), under controlled and field conditions. Values of $\beta$ around 2, 4 and 8 , for rust, angular leaf spot and anthracnose, respectively, were constant when determined at different evaluation times after infection and crop phenological stages, temperatures of disease development, and two bean cultivars. These values were dependent on the mechanisms by which the pathogens interact with the host and the different symptoms caused by diseases.

Finally, by the incorporation of $\beta$ value on disease severity estimates, the area under virtual disease progress curve (AUVPC) did not show relationship to yield like the area under disease progress curve $(A U D P C)$. However, variables that considered the active photosynthesizing area $(P A D$ e $P A A)$ explained better the variations on yield of diseased plants compared to variables that considered only the remaining green leaf area $(H A D$ e $H A A)$. 


\section{INTRODUÇÃO}

Entre as causas apontadas para a baixa produtividade nacional de feijão, algumas doenças foliares, como crestamento bacteriano, mosaico dourado, ferrugem, antracnose e mancha angular, têm se destacado em função da freqüência de aparecimento e dos danos causados à produção desta cultura (Menezes \& Menten, 1997).

A necessidade de dados confiáveis a respeito dos danos causados por estas doenças tem aumentado com a tendência de se adotarem práticas de manejo integrado de doenças. Sem estas estimativas de redução na produção dificilmente o agricultor poderá decidir quanto investir e quais medidas tomar para o controle econômico destas doenças. Apesar de terem sido realizadas várias tentativas de correlacionar a severidade de doenças foliares com a produção na cultura do feijoeiro, esta relação dano-doença ainda não está bem definida, pois a produção nesta cultura tem se correlacionado mais com a área foliar sadia, verde e fotossintetizante que com a área foliar doente e necrosada pelo patógeno (Bergamin Filho et al., 1997; Bianchini, 1998; Canteri, 1998; Carneiro et al., 1997; Gianasi, 1999; Iamauti, 1995; Nunes \& Bergamin Filho, 1996; Silva et al., 1998a; Silva et al., 1998b).

Entre os muitos fatores que tentam explicar esta falta de correlação entre severidade de doença e produção nesta cultura pode-se destacar a falta de um conhecimento mais acurado dos efeitos causados pelos patógenos na interceptação da radiação solar e na eficiência de uso desta radiação, fatores que determinam a produtividade (Johnson, 1987).

Diante do exposto, o objetivo deste trabalho foi analisar o efeito de três patógenos foliares (Uromyces appendiculatus, Colletotrichum lindemuthianum e 
Phaeoisariopsis griseola) nos processos fisiológicos de folhas de feijoeiro por meio de ensaios em condições controladas e de campo.

Primeiramente, utilizando-se câmaras de crescimento, foi feito um acompanhamento do efeito do patógeno na taxa de respiração no escuro, taxa líquida de fotossíntese, taxa de transpiração, condutância estomática e variáveis relacionadas com a emissão de fluorescência da clorofila $a$ de folhas infectadas, para se ter uma visão detalhada das mudanças causadas pelo patógeno no hospedeiro durante todo processo de desenvolvimento da doença sob diferentes temperaturas e em duas cultivares de feijoeiro. Em seguida, foi estudada a curva de resposta da taxa de assimilação de $\mathrm{CO}_{2}$ versus a concentração intercelular de $\mathrm{CO}_{2}(\mathrm{~A} / \mathrm{C} i)$ de folhas doentes com cada patógeno para determinar quais fatores são responsáveis pela redução da taxa fotossintética nestas folhas doentes. Posteriormente, como objetivo maior deste trabalho, foram estabelecidas relações entre a severidade de cada doença e o seu efeito na atividade fotossintética das folhas de feijoeiro doentes, aplicando-se o conceito de lesão virtual proposto por Bastiaans (1991), em condições controladas e no campo. Foram verificadas as influências de diferentes épocas de avaliação após a infecção e estádios fenológicos da cultura, temperaturas de desenvolvimento da doença e cultivares de feijoeiro na determinação desta relação entre severidade de doença e redução da taxa fotossintética líquida de folhas doentes de feijoeiro. Finalmente, com o estabelecimento destas relações, elas foram incorporadas no cálculo das variáveis de área sob a curva de progresso da doença $(A U D P C)$, duração da área foliar sadia $(H A D)$ e absorção da área foliar sadia $(H A A)$ para o estabelecimento de relações de danos na cultura do feijoeiro. 


\section{REVISÃO DE LITERATURA}

\subsection{Doenças do feijoeiro}

\subsubsection{Importância da cultura e das doenças do feijoeiro}

O feijoeiro comum, Phaseolus vulgaris L., tem se destacado como uma fonte de proteína na dieta alimentar do povo brasileiro e de boa parte da América Latina. A sua boa adaptação às mais variadas condições de clima e solo do Brasil faz com que seja cultivado ao longo do ano por todo o país, tanto para o consumo familiar dos pequenos e médios produtores, como em escala comercial por médios e grandes produtores (Yokoyama et al., 1996).

Considerando apenas o gênero Phaseolus, o Brasil é o maior produtor mundial de feijão e, nos últimos cinco anos, a produção nacional tem variado de 2,2 a 3,2 milhões de toneladas anuais provenientes de 4,0 a 5,4 milhões de hectares (Feijão, 1999).

A produtividade média da cultura do feijoeiro no Brasil, estimada em $665 \mathrm{~kg} / \mathrm{ha}$ na safra 98/99 (Feijão, 1999), é considerada baixa quando comparada com o potencial produtivo da espécie, superior a $3000 \mathrm{~kg} / \mathrm{ha}$, quando aplicadas todas tecnologias recomendadas (Portes, 1996). Os danos causados por doenças, entre inúmeros fatores, contribuem para a baixa produtividade nacional e merecem consideração.

Entre as mais de 300 doenças, causadas por vírus, bactérias, fungos e nematóides, que atacam o feijoeiro no Brasil, algumas doenças de solo, como o mofo branco, a mela e as podridões radiculares, e algumas doenças foliares, como o mosaico dourado, mosaic comum, o crestamento bacteriano comum, a antracnose, a mancha 
angular e a ferrugem, têm, atualmente, se destacado em função da freqüência de aparecimento e dos danos causados à produção do feijoeiro no Brasil (Cardoso et al., 1996; Faria et al., 1996; Menezes \& Menten, 1997; Sartorato et al., 1996).

\subsubsection{Antracnose do feijoeiro}

\subsubsection{Importância}

A antracnose do feijoeiro é considerada uma das doenças mais graves que atinge esta cultura no Brasil, uma vez que encontra-se amplamente distribuída. Pode atingir toda a parte aérea da planta e, ao encontrar condições favoráveis, causar grandes reduções na produção (Bianchini et al., 1997, Rava \& Sartorato, 1994).

Quando cultivares suscetíveis são utilizadas em regiões de temperaturas amenas e alta umidade, esta doença pode causar redução na produção de até $100 \%$, principalmente, quando sementes contaminadas são usadas para o plantio (Schwartz, 1991). Quanto mais precoce for o aparecimento da doença na lavoura maiores serão os danos em rendimento de grãos e na depreciação do produto, que se apresenta manchado (Rava \& Sartorato, 1994).

\subsubsection{Etiologia}

O agente causal da antracnose é o fungo ascomiceto Glomerella lindemuthiana Shear, entretanto a fase imperfeita, Colletotrichum lindemuthianum (Sacc. \& Magnus) Lams.-Scrib., é mais comumente encontrada no feijoeiro (Schwartz, 1991).

Este fungo é considerado um parasita facultativo, sobrevivendo de uma estação de cultivo para outra em restos de cultura ou em sementes contaminadas na forma de micélio dormente ou conídios e sendo disseminado pelas sementes, ar e respingos de água (Schwartz, 1991). Em condições favoráveis, entre 6 e 9 horas, os conídios podem germinar e formar o apressório, que se prende à superficie do hospedeiro e exerce uma 
pressão mecânica para a penetração através da cutícula e epiderme (Mordue, 1971). Numa fase inicial biotrófica, as hifas infectivas incham e crescem entre a parede celular e o protoplasto, com a produção de enzimas poligalacturonases, que degradam os polímeros de pectina (Wijesundera et al., 1989), durante 2-4 dias, sem causar danos aparentes às células do hospedeiro (Mordue, 1971). Em seguida, na fase necrotrófica, a parede das células vegetais é degradada pela ação de enzimas pectina-liases, levando ao surgimento de lesões aquosas que escurecem devido à alta concentração de taninos (Wijesundera et al., 1989). O micélio agrega-se dentro das lesões, formando os acérvulos que rompem a cutícula do hospedeiro (Mordue, 1971). Desta forma, este fungo pode ser classificado como hemibiotrófico, uma vez que no início do processo de infecção, apresenta uma fase biotrófica e, em seguida, uma fase necrotrófica (Luttrell, 1974; O'Connell et al., 1985; O’Connell \& Bailey, 1991).

\subsubsection{Sintomatologia}

Os sintomas da antracnose podem ocorrer em toda parte aérea do feijoeiro. Durante a germinação, sementes infectadas produzem lesões escuras nos cotilédones e hipocótilo, podendo causar podridão do colo da planta. No caule e em hastes mais velhas as lesões chegam a atingir 5-7 mm de comprimento (Schwartz, 1991).

As lesões características marrom-escuras ou pardas, alongadas e deprimidas ocorrem com maior frequência nos pecíolos e nas nervuras principais e secundárias da superficie inferior das folhas. Em casos de infecção severa, formam-se manchas necrosadas no limbo foliar adjacente às nervuras, podendo atingir a superficie superior das folhas (Bianchini et al., 1997; Schwartz, 1991; Zaumeyer \& Thomas, 1957).

Nas vagens, as manchas são arredondadas, deprimidas, pardo-escuras, circundadas por bordos salientes pardo-avermelhados. As vagens novas podem murchar e secar caso a infecção seja severa. A partir das vagens o fungo pode atingir o tegumento e os cotilédones da semente em desenvolvimento. As sementes infectadas apresentam-se 
freqüentemente descoloridas e com lesões na forma de cancros ligeiramente deprimidos (Bianchini et al., 1997; Schwartz, 1991).

A esporulação pode ocorrer nas lesões em pecíolos, nervuras principais e vagens. O centro destas lesões torna-se descolorido e durante períodos de baixa temperatura e alta umidade os conídios são produzidos numa matriz gelatinosa de coloração rosada que escurece quando seca (Schwartz, 1991).

\subsubsection{Fatores ambientais que interferem no desenvolvimento da doença}

A produção de conídios de $C$. lindemuthiamum e a infecção na planta são favorecidas por temperaturas de 13 a $26^{\circ} \mathrm{C}$, com um ótimo de $17{ }^{\circ} \mathrm{C}$ (Crispín et al., 1976; Dalla Pria, 1997; Schwartz, 1991; Tu, 1992). Temperaturas superiores a $28-30{ }^{\circ} \mathrm{C}$ e inferiores a $13{ }^{\circ} \mathrm{C}$ limitam tanto a infecção quanto o desenvolvimento do fungo (Crispín et al., 1976; Tu, 1982; Tu, 1992), não havendo desenvolvimento de antracnose nas temperaturas de 6 e $33^{\circ} \mathrm{C}$ (Dalla Pria, 1997).

Quanto maior a temperatura, menor o período de incubação da antracnose até uma temperatura ótima. Na cv. Rosinha, o menor período de incubação (105 horas) foi observado a $29{ }^{\circ} \mathrm{C}$, enquanto que na cv. Carioca o menor período de incubação (125 horas) foi observado a $25{ }^{\circ} \mathrm{C}$. Este período foi duas e três vezes mais longo na cv. Carioca e cv. Rosinha a $10^{\circ} \mathrm{C}$, respectivamente (Dalla Pria, 1997).

Para a germinação dos conídios, incubação e subseqüente esporulação, água livre ou umidade relativa superior a 92\% são necessárias (Schwartz, 1991). Chuvas moderadas a intervalos freqüentes, principalmente se acompanhadas de vento e de respingos, são essenciais para a disseminação a curta distância e desenvolvimento de severas epidemias (Crispín et al., 1976).

Períodos de molhamento foliar entre 18 a 24 horas proporcionam um acentuado aumento de tecido doente, mas períodos superiores a 24 horas não incrementam a severidade da antracnose do feijoeiro. Já períodos de molhamento foliar inferiores a 6 horas impedem o desenvolvimento da doença (Dalla Pria, 1997). 


\subsubsection{Mancha angular do feijoeiro}

\subsubsection{Importância}

A mancha angular do feijoeiro ocorre em todas as regiões em que se cultiva esta leguminosa, afetando com maior ou menor intensidade todas as variedades recomendadas (Sartorato, 1989; Sartorato \& Rava, 1994).

Por muito tempo, a mancha angular do feijoeiro foi considerada uma doença de importância secundária, de ocorrência tardia nas plantações e sem causar grandes danos à produção (Paradella Filho, 1972). Entretanto, nos últimos anos, com o plantio de materiais suscetíveis aliado às condições de ambiente favoráveis (Sartorato, 1989), especialmente nas safras da seca e de inverno em plantios irrigados por aspersão (Menezes, 1994), ela tem causado danos severos à produção, passando a ser considerada uma das principais doenças da cultura do feijoeiro (Sartorato \& Rava, 1994; Sartorato et al., 1996).

Os danos à cultura, no Brasil, são atribuídos ao desfolhamento e à maturação precoce das plantas e variam de 7 a $70 \%$ em função do grau de resistência das variedades, das condições ambientais e da patogenicidade dos isolados (Bergamin Filho et al., 1997; Carneiro et al., 1997; Issa et al., 1980; Mora Brenes, 1983; Rava et al., 1985; Sartorato \& Rava, 1992; Silva et al., 1998a; Silva et al., 1998b).

\subsubsection{Etiologia}

$\mathrm{O}$ agente causal da mancha angular do feijoeiro é o fungo deuteromiceto Phaeoisariopsis griseola (Sacc.) Ferraris, com os sinônimos Isariopsis griseola Sacc., Graphium laxum Ell., Isariopsis laxa (Ell.) Sacc., Cercospora columnare Ell. \& Ev., Cercospora sthulmanni Henn. e Lindaumyces griseola Gonz. Frag. (Ferraz, 1980; Llanos, 1957). 
O fungo é considerado um parasita facultativo e sobrevive de uma estação de cultivo para outra em restos de cultura sobre a superficie do solo (Cardona-Alvarez \& Walker, 1956; Sindhan \& Bose, 1979) ou em sementes contaminadas na forma de micélio dormente ou conídios (Diáz et al., 1965). Também pode ser classificado como hemibiotrófico, uma vez que se alimenta tanto de tecido vivo como de tecido necrosado do hospedeiro (Luttrell, 1974).

A liberação dos conídios é favorecida pelo clima seco e a disseminação ocorre, principalmente, pelo vento e água de chuva ou irrigação (Bianchini et al., 1997; Campos \& Zak, 1980; Cardona-Alvarez \& Walker, 1956; Saettler, 1991).

A infecção inicia com a germinação dos conídios sobre a superficie foliar e com a penetração do tubo germinativo através dos estômatos. As hifas, então, crescem intercelularmente através das células do mesófilo provocando a desintegração dos cloroplastos e a necrose destas células, três dias após a penetração. A desintegração das células se estende ao parênquima esponjoso, às células paliçádicas e às células da epiderme superior da folha. Nove dias após a penetração, o fungo se desenvolve intracelularmente através dos tecidos necrosados, mas é restrito pelos feixes vasculares (Cardona-Alvarez \& Walker, 1956). Sob condições de alta umidade, os conídios são, então, produzidos na superficie inferior da folha e servirão de inóculo secundário dentro da lavoura (Sartorato \& Rava, 1994)

\subsubsection{Sintomatologia}

Os sintomas da mancha angular manifestam-se principalmente nas folhas, podendo ocorrer nas hastes e vagens. As primeiras lesões podem aparecer nas folhas primárias com forma mais ou menos circular, com halos concêntricos e de cor castanhoescura. O sintoma característico manifesta-se nas folhas trifolioladas como lesões de forma angular delimitadas pelas nervuras, inicialmente de cor cinzenta e posteriormente castanha. Entretanto, devido à combinação isolado-hospedeiro, as lesões podem variar de irregulares a circulares (Bianchini et al., 1997; Menezes, 1994; Saettler, 1991; Sartorato, 
1990; Sartorato \& Rava, 1994; Sartorato et al., 1996). Quando as lesões atingem por volta de $20-30 \%$ da área foliar, elas coalescem causando o amarelecimento, necrose e queda prematura da folha (Ferraz, 1980; Godoy, 1995; Mora Brenes, 1983). Além disso, folhas com mancha angular apresentam uma redução do conteúdo de clorofila semelhante à severidade de doença, mas a redução na assimilação líquida de $\mathrm{CO}_{2}$ mostra-se proporcionalmente maior (Bassanezi, 1995). Vários autores (Bergamin Filho et al., 1997; Canteri, 1998; Carneiro et al., 1997) apontam a necessidade de estudos mais detalhados do efeito da mancha angular na fotossíntese de folhas de feijoeiro para avaliar se o efeito da doença é devido somente à redução do tecido foliar verde ou a um efeito na utilização da radiação interceptada pela planta.

Nas vagens, as lesões são superficiais, quase circulares, de cor castanhoavermelhada e bordos escuros. Nas hastes, as lesões são alongadas e de cor castanhoescura (Bianchini et al., 1997; Menezes, 1994; Saettler, 1991; Sartorato, 1990; Sartorato \& Rava, 1994; Sartorato et al., 1996).

\subsubsection{Fatores ambientais que interferem no desenvolvimento da doença}

A temperatura ótima para o crescimento de $P$. griseola é $24^{\circ} \mathrm{C}$, sendo a mínima $8{ }^{\circ} \mathrm{C}$ e a máxima entre 30 e $36^{\circ} \mathrm{C}$ (Campos \& Zak, 1980; Cardona-Alvarez \& Walker, 1956; Sartorato \& Rava, 1994). A germinação dos conídios ocorre a partir de $8^{\circ} \mathrm{C}$ até 32 ${ }^{\circ} \mathrm{C}$, com um ótimo entre 20 e $28^{\circ} \mathrm{C}$, não sendo observada germinação a $36^{\circ} \mathrm{C}$. A infecção ocorre desde $10^{\circ} \mathrm{C}$ até $28^{\circ} \mathrm{C}$, com um desenvolvimento mais rápido a $24^{\circ} \mathrm{C}$, não sendo observada a 6 e $29^{\circ} \mathrm{C}$ (Bassanezi, 1995; Cardona-Alvarez \& Walker, 1956; Dalla Pria, 1997; Saettler, 1991).

O período de incubação da doença varia com a temperatura, sendo de 5 a 23 dias. O menor período de incubação ocorre em temperaturas em torno de $22-28{ }^{\circ} \mathrm{C}$ (Campos \& Zak, 1980; Llanos, 1957; Olave, 1958; Sartorato \& Rava, 1994). Na faixa de temperatura ideal para o desenvolvimento da doença $\left(24-25^{\circ} \mathrm{C}\right)$ o período de incubação varia de 8 a 10 dias, (Bassanezi, 1995; Dalla Pria, 1997). 
A severidade da doença, o desfolhamento e a clorose devida à infecção ocorrem mais rapidamente em plantas mantidas a $24-30{ }^{\circ} \mathrm{C}$ do que a $16{ }^{\circ} \mathrm{C}$ (Llanos, 1957). Da mesma forma, Inglis \& Hagedorn (1986) observaram 100\% de desfolha quando a infecção ocorreu a 24 e $28{ }^{\circ} \mathrm{C}$ e as plantas permaneceram em 20 e $24{ }^{\circ} \mathrm{C}$; 60-67\% quando a infecção ocorreu a $20{ }^{\circ} \mathrm{C}$ e as plantas permaneceram em 20 e $24{ }^{\circ} \mathrm{C}$; muito pouca desfolha quando tanto a infecção quanto a pós-incubação foram a 16 ou $28{ }^{\circ} \mathrm{C}$. A temperatura também afeta a taxa de crescimento das lesões, atingindo um máximo à medida que se aproxima do ponto ótimo para o desenvolvimento da doença, $25^{\circ} \mathrm{C}$ (Dalla Pria, 1997).

Aliados a temperaturas moderadas em torno de $24{ }^{\circ} \mathrm{C}$, períodos chuvosos ou longos períodos de alta umidade relativa (95 a 100\%), alternados por baixa umidade, são os fatores climáticos mais importantes no desenvolvimento das epidemias de mancha angular (Cardona-Alvarez \& Walker, 1956; Diáz et al., 1965). A produção de conidióforos só ocorre na presença de alta umidade relativa (Cardona-Alvarez \& Walker, 1956; Sartorato \& Rava, 1994), mas a germinação dos conídios só ocorre com a presença de água livre na superficie da folha (Sartorato \& Rava, 1994).

A severidade da doença depende do período de câmara úmida em que as plantas são mantidas após a inoculação. Com 3 horas de câmara úmida já ocorre a infecção, mas a severidade da doença aumenta com o aumento deste período de câmara úmida, havendo um máximo em torno de 40 a 56 horas (Campos \& Zak, 1980; Cardona-Alvarez \& Walker, 1956; Dalla Pria, 1997; Llanos, 1957). É proposto um tempo de 48 a 72 horas de câmara úmida para testes de variedades com o patógeno (Sartorato \& Rava, 1994).

\subsubsection{Ferrugem do feijoeiro}

\subsubsection{Importância}

Considerada uma das mais importantes doenças da parte aérea do feijoeiro, a ferrugem pode causar limitação na produção, principalmente quando coincidem raças 
virulentas do fungo, variedades suscetíveis do hospedeiro e ambiente favorável para o desenvolvimento da doença. A produção pode ser reduzida em até $68 \%$ se as plantas forem infectadas na época de floração e enchimento de vagens, ao redor de 30-50 dias após a germinação (Almeida et al., 1977; Carrijo et al., 1979; Vieira, 1983; Zambolim et al., 1982).

\subsubsection{Etiologia}

O agente causal da ferrugem do feijoeiro é o fungo basidiomiceto, da ordem Uredinales, Uromyces appendiculatus (Pers.) Unger, anteriormente com os sinônimos, não mais válidos, Uromyces phaseoli var. phaseoli ou Uromyces phaseoli var. typica (Stavely, 1991).

Este fungo é um parasita obrigatório, isto é, depende do hospedeiro para sua sobrevivência, sendo também classificado como biotrófico uma vez que obtém seu alimento do tecido vivo no qual ele completa seu ciclo de vida (Luttrell, 1974). O fungo apresenta as fases de pícnio, écio, urédio e télio em um só hospedeiro, constituindo-se no que se chama de ferrugem autóica e macrocíclica (Bianchini et al., 1997; Rios, 1994; Stavely, 1991; Zambolim et al., 1982).

Os urediniósporos são disseminados facilmente pelo vento a curtas e longas distâncias e também pelo homem, animais, insetos e implementos agrícolas (Bianchini et al., 1997; Stavely, 1991).

A infecção inicia-se quando os urediniósporos, produzidos assexuadamente, germinam e entram em contato com as células-guardas dos estômatos formando o apressório, a vesícula subestomatal e a hifa de infecção (Staples, 1985; Vargas, 1980). O micélio formado no espaço intercelular não tem efeito sobre o hospedeiro, mas após a adesão da célula mãe do haustório à célula vegetal ocorre a invaginação celular junto ao haustório e a retirada de alimento para o fungo (Pring, 1980).

Durante o ciclo da cultura, ocorrem repetidas gerações de urediniósporos, caracterizando uma doença policíclica. O padrão de esporulação é do tipo intermitente 
com vários picos durante o período infeccioso (Aust et al., 1984; Imhoff et al., 1982; Mendes \& Bergamin Filho, 1990).

\subsubsection{Sintomatologia}

Os sintomas da ferrugem manifestam-se principalmente nas folhas, podendo ocorrer nas hastes e vagens. Inicialmente, surgem pequenas manchas esbranquiçadas, puntiformes, levemente salientes (“flecks"), após 5-6 dias da infecção. Posteriormente, ocorre o rompimento da epiderme foliar e a exposição dos urediniósporos, com coloração marrom-avermelhada, de aspecto ferruginoso. Ao redor dos soros pode haver a formação de halos amarelados e, também, o aparecimento de pequenas pústulas secundárias. A produção de urediniósporos nas pústulas cessa gradualmente em poucas semanas, podendo ocorrer a produção de teliósporos. As folhas severamente atacadas tornam-se amarelas, secam e caem (Bianchini et al., 1989; Bianchini et al., 1997; Menezes, 1994; Rios, 1994; Sartorato et al., 1996; Stavely, 1991; Vargas, 1980; Vieira, 1983; Zambolim et al., 1982). O fungo, ao redor da pústula, ocasiona a desorganização do mesófilo e grande redução no tamanho das células afetadas (Pring, 1980).

As folhas de feijoeiro com ferrugem podem ter a fotossintese inibida em relação às folhas sadias, expressa na redução do conteúdo de clorofila e redução da assimilação líquida de $\mathrm{CO}_{2}$ (Bassanezi, 1995). Uma folha primária sadia exporta para raízes e caule $50 \%$ do produto sintetizado, enquanto que uma folha doente, menos de $2 \%$ (Livne \& Daly, 1966). Livne (1964) concluiu que a diminuição da capacidade fotossintética de folhas de feijoeiro com ferrugem foi, provavelmente, devida à perda de clorofila. Entretanto, a redução da assimilação líquida de $\mathrm{CO}_{2}$ estaria também associada à presença do patógeno, que absorvendo os produtos fotossintetizados e acumulando carboidratos, inibe a translocação de fotossintetizados das folhas infectadas, limitando a disponibilidade de nutrientes às raízes e sementes em desenvolvimento (Livne \& Daly, 1966; Zaki \& Durbin, 1965). Isto, em parte, explicaria porque a redução na assimilação líquida de $\mathrm{CO}_{2}$ pelas folhas afetadas parece ser maior que a redução esperada pela simples perda da área 
foliar verde avaliada pela estimativa de severidade de ferrugem na folha (Bassanezi, 1995).

$\mathrm{Na}$ folha senescente, ocorre um aumento na síntese de clorofila nos sítios de infecção, podendo esta ser a explicação para o aparecimento de "ilhas verdes" ao redor das pústulas em folhas já amareladas (Sziráki et al., 1984).

\subsubsection{Fatores ambientais que interferem no desenvolvimento da doença}

Regiões tropicais, subtropicais e de clima temperado úmido, que apresentam temperaturas moderadas e alta umidade relativa são favoráveis à ocorrência da doença (Rios, 1994; Vieira, 1983).

A temperatura parece afetar todos os processos de desenvolvimento da doença. A melhor combinação temperatura diurna-noturna para o desenvolvimento da doença é de $26,6-21,1^{\circ} \mathrm{C}$. Em temperaturas mais elevadas $\left(32,2-26,6^{\circ} \mathrm{C}\right)$ há ausência de sintomas e em temperaturas mais baixas $\left(26,6-15,5^{\circ} \mathrm{C}\right)$ há um atraso no aparecimento dos sintomas (Schein, 1961). Temperaturas abaixo de $7{ }^{\circ} \mathrm{C}$ e acima de $27^{\circ} \mathrm{C}$ atrasam o desenvolvimento da ferrugem do feijoeiro, e podem paralisá-lo se ocorrerem por longo período de tempo (Bacchi, 1993; Bassanezi, 1995).

A germinação de urediniósporos apresenta como temperatura mínima e máxima, 4 e $27,5^{\circ} \mathrm{C}$, respectivamente. Entre 15 e $24^{\circ} \mathrm{C}$, a taxa de germinação se mostra similar, porém, a $24^{\circ} \mathrm{C}$, a penetração é prejudicada pela redução na formação de apressórios, e a $15^{\circ} \mathrm{C}$, o crescimento do tubo germinativo é retardado (Alten, 1983; Imhoff et al., 1981).

Temperaturas altas durante a fase de penetração resultam na desorientação dos tubos germinativos e conseqüente decréscimo na frequêencia de infeç̧ão (Alten, 1983). Na pré-penetração, as condições ambientais ótimas para o desenvolvimento da doença parecem estar entre $15-20^{\circ} \mathrm{C}$ e 24 horas de orvalho (Code et al., 1985). Na póspenetração, o desenvolvimento da doença é favorecido entre 20 e $26{ }^{\circ} \mathrm{C}$, o número de pústulas é maior, na faixa de $14-24^{\circ} \mathrm{C}$, e os menores períodos latentes, na faixa de $20-26$ ${ }^{\circ} \mathrm{C}$, não havendo doença na faixa de $28-38^{\circ} \mathrm{C}$ (Bacchi, 1993; Code et al., 1985). Neste 
patossistema enquanto os menores períodos de incubação e latência ocorrem a $21^{\circ} \mathrm{C}$, a maior freqüência de infecção ocorre a $17{ }^{\circ} \mathrm{C}$ (Bassanezi, 1995; Mendes \& Bergamin Filho, 1989). O período de incubação é de 7 dias na faixa de temperatura de $15-20{ }^{\circ} \mathrm{C}$ e o período latente, de 9 dias (Code et al., 1985). A maior produção de urediniósporos ocorre a $21^{\circ} \mathrm{C}$ e o período de esporulação e a capacidade germinativa dos urediniósporos produzidos diminuem ou cessam a temperaturas maiores (Imhoff et al., 1981). A taxa de crescimento das lesões varia com a temperatura, sendo as maiores taxas observadas entre 17 e $21{ }^{\circ} \mathrm{C}$ (Bassanezi, 1995; Imhoff et al., 1982).

O período mínimo de molhamento sobre a folha do feijoeiro necessário para a ocorrência da ferrugem é de 4 a 8 horas, dependendo da temperatura (Code et al., 1985; Imhoff et al., 1981; Mendes \& Bergamin Filho, 1989). Porém, não é observado um efeito sobre o período latente e a freqüência de infecção em períodos de molhamento acima de 15 ou 20 horas (Bacchi, 1993; Galvão \& Menten, 1987).

Quanto maior a umidade, maior a produção de esporos por U. appendiculatus, e um curto período de água livre (0,5 a 1 hora) aumenta o número de esporos liberados (Yarwood, 1961).

\subsection{Doenças como fator de estresse e seu efeito em processos físiológicos do hospedeiro}

Fator de estresse de plantas é considerado "qualquer condição desfavorável ou substância que afete ou bloqueie o metabolismo, crescimento e desenvolvimento da planta" (Lichtenthaler, 1996, p.4). Portanto, as doenças de plantas, "que resultam em mudanças adversas na forma, função ou integridade da planta e podem levar ao dano parcial ou morte da planta ou de suas partes” (Agrios, 1997, p.4), estão entre os vários fatores de estresse vegetal citados por Lichtenthaler (1996).

A invasão de plantas por um organismo estranho leva, cedo ou tarde, a mudanças nos diversos processos fisiológicos da planta hospedeira, incluindo a respiração, fotossíntese, translocação de nutrientes e água, transpiração e regulação de 
crescimento. Uma análise destas mudanças durante e após a infecção da planta hospedeira pelo patógeno pode esclarecer os modos pelos quais os patógenos causam doença e ajudar a elucidar os mecanismos pelos quais as plantas resistem ao ataque dos patógenos (Lucas, 1998).

Entre os processos fisiológicos da planta hospedeira alterados por patógenos foliares destacam-se a taxa fotossintética, a taxa de respiração no escuro (dark respiration), a taxa de transpiração e a resistência do mesófilo e dos estômatos à difusão do $\mathrm{CO}_{2}$.

\subsubsection{Alterações na fotossíntese de plantas doentes}

A fotossíntese é o processo pelo qual a energia luminosa captada pela clorofila é utilizada para síntese de ATP e NADPH, usados como fonte de energia para síntese de carboidratos a partir de $\mathrm{CO}_{2}$ e $\mathrm{H}_{2} \mathrm{O}$, com liberação simultânea de $\mathrm{O}_{2}$ para a atmosfera (Salisbury \& Ross, 1992). Pode-se dizer, então, que a quantidade de radiação solar interceptada pela área foliar verde e a eficiência do uso desta radiação são os fatores determinantes da produção de matéria seca e, conseqüentemente, da produção de grãos pela planta (Monteith, 1977; Monteith, 1981).

A maioria dos fatores de estresse vegetal, mesmo que não afetem diretamente a composição do aparato fotossintético e suas funções, irá afetar o processo fotossintético ao longo do tempo (Lichtenthaler, 1996). A despeito de sua fundamental importância como processo fisiológico chave determinante do potencial produtivo de uma cultura, comparativamente pouco é conhecido sobre os efeitos de patógenos na fotossíntese (Lucas, 1998).

Das poucas generalizações que podem ser feitas com respeito à maneira pela qual os patógenos afetam a fotossintese, pode-se dizer que na maioria das interações patógeno/hospedeiro as taxas fotossintéticas líquida e bruta diminuem com o progresso da infecção. Parece óbvio que a redução da interceptação da radiação solar pela planta doente, em razão da destruição, necrose, morte ou queda precoce dos tecidos 
fotossintetizantes da planta, é o principal resultado da invasão do patógeno na redução da capacidade fotossintética da planta. Contudo, não se pode ignorar a possibilidade de que existam efeitos nos tecidos foliares não infectados adjacentes, implicando numa mudança da eficiência fotossintética neste tecido remanescente (Agrios, 1997; Goodman et al., 1986; Leite \& Pascholati, 1995; Lucas, 1998; Scholes, 1992).

Nesta revisão, em razão do escopo deste trabalho, apenas os efeitos de fungos fitopatogênicos serão abordados. Os fungos fitopatogênicos podem ser divididos em dois grupos baseados na sua relação com o hospedeiro: parasitas obrigatórios e parasitas facultativos. Fungos parasitas obrigatórios, tais como ferrugens e oídios, dependem da viabilidade do tecido do hospedeiro para completar seu desenvolvimento, sendo também classificados de biotróficos uma vez que obtêm seu alimento do tecido vivo no qual completam seu ciclo de vida. Por sua vez, fungos parasitas facultativos, tais como os causadores de manchas foliares, murchas e podridões, requerem a planta hospedeira para parte do ciclo de vida, mas podem completar seu ciclo em restos de cultura morta. Estes últimos são, também, classificados como necrotróficos, se obtêm o alimento de tecidos necrosados e mortos do hospedeiro, ou como hemibiotróficos, se numa curta fase inicial obtêm o alimento de tecido vivo e posteriormente se comportam como necrotróficos (Agrios, 1997; Luttrell, 1974). Como o padrão de resposta à redução da fotossíntese está aparentemente relacionado ao tipo de relação trófica (Shtienberg, 1992), os fungos biotróficos são tratados separadamente dos hemibiotróficos e necrotróficos.

\subsubsection{Fungos hemibiotróficos e necrotróficos}

O principal efeito das doenças na redução da produção das culturas é pela redução na interceptação de luz pelas folhas, resultante de uma menor área foliar fotossinteticamente ativa (Haverkort \& Bicamumpaka, 1986; Madeira et al., 1988; Waggoner \& Berger, 1987), que ocorre claramente quando as folhas caem ou têm sua área tomada por manchas necróticas como resultado da infecção por um fungo necrotrófico ou hemibiotrófico. 
Alguns fungos necrotróficos reduzem a interceptação de luz pela planta e, conseqüentemente, a fotossíntese acelerando a senescência foliar e/ou induzindo a desfolha. Boote et al. (1980) observaram uma redução de $80 \%$ do índice de área foliar em plantas de amendoim atacadas por Cercospora arachidicola e Cercosporidium personatum devido à abscisão de folhas severamente atacadas. A desfolha induzida pelo patógeno seria neste patossistema o principal componente de redução da fotossíntese da planta (Bourgeois \& Boote, 1992). A aceleração da senescência das folhas foi apontada por Johnson et al. (1987) como uma das principais causas de redução da área foliar verde da cultura da batata infectada com Alternaria solani. Silva et al. (1998a) e Gianasi (1999) consideram a desfolha precoce de plantas de feijoeiro causada pela mancha angular e antracnose, respectivamente, um dos fatores que devem ser levados em consideração na avaliação dos danos causados por essas doenças nesta cultura.

Antes da desfolha, porém, o primeiro sintoma causado por parasitas facultativos nas folhas infectadas é a clorose, indicando uma redução no conteúdo de clorofila dos tecidos verdes. Esta redução, causada pela destruição e/ou inibição da síntese de clorofila ou redução no número de cloroplastos, resulta numa menor assimilação de $\mathrm{CO}_{2}$ pela plantas doentes (Agrios, 1997; Goodman et al., 1986; Leite \& Pascholati, 1995; Lucas, 1998; Scholes, 1992). Além da destruição das organelas celulares, inclusive os cloroplastos, por ação de enzimas degradadoras produzidas pelos patógenos, a redução no conteúdo de clorofila pode estar associada à produção de algum metabólito tóxico pelo fungo durante a infecção. Toxinas produzidas por espécies de Alternaria (Fulton et al., 1965; Janardhanan \& Husain, 1984) e Bipolaris (Navarre \& Wolpert, 1999; Rasmussen \& Scheffer, 1988) inibem a produção de clorofila em várias culturas e aceleram a senescência foliar. Também, toxinas como helminthosporal, produzida por Bipolaris sorokiniana, inibem o transporte de elétrons de cloroplastos isolados de trigo ao nível do fotossistema II e do complexo citocromo b/f (Tarabrin \& Bystrykh, 1990), inibindo a fotofosforilação não-cíclica e a mudança na regulação fisiológica das reações acumuladoras de energia (Tarabrin, 1995). 
Lesões necróticas, caracterizadas pela degeneração do protoplasma, seguida de morte de células e tecidos, são fotossinteticamente inativas. Entretanto, como relatado em alguns trabalhos, deve existir um efeito na fotossíntese nas áreas não infectadas de folhas doentes, em folhas assintomáticas de plantas doentes e em áreas infectadas antes de ocorrer a morte celular e a necrose dos tecidos, resultando numa menor eficiência do uso da radiação absorvida.

Boote et al. (1980) relataram que a fotossíntese de plantas de amendoim com manchas foliares de $C$. arachidicola e $C$. personatum foram reduzidas não apenas pela perda de folhas, que caíram como resultado da infecção, mas também porque as folhas doentes foram menos eficientes em fixar $\mathrm{CO}_{2}$. Para folhas de amendoim com $C$. personatum, Bourgeois \& Boote (1992) observaram que uma severidade de $15 \%$ causou uma redução de $65 \%$ na taxa fotossintética.

Em folhas de cevada infectadas com Rhynchosporium secalis, Martin (1986) também observou reduções na fotossíntese líquida máxima maiores que a esperada pela simples redução da área verde da folha, sugerindo uma menor taxa fotossintética tanto nas áreas verdes da folha como no tecido lesionado.

Efeito semelhante foi relatado por Ephrath et al. (1989) em folhas de algodoeiro infectadas com Alternaria alternata. Os autores sugeriram que uma possivel explicação seria a produção e secreção de um composto fitotóxico pelo patógeno que estaria difuso na área em torno de cada lesão provocando um halo invisível no qual a fotossíntese já estivesse comprometida.

Para Levy \& Leonard (1990), os efeitos observados da infecção de Exserohilum turcicum na eficiência fotossintética do tecido adjacente à lesão e na translocação de fotoassimilados de outras partes da folha para a lesão mostraram que o efeito desta doença na produção de milho doce foi maior que o que poderia ser esperado pela perda direta de área foliar pela necrose nas lesões.

A infecção de Pyricularia grisea, agente causal da brusone, também reduziu a fotossíntese líquida de folhas de arroz infectadas além daquela que seria explicada pela simples redução da área verde da folha (Bastiaans, 1991; Bastiaans, 1993; Bastiaans \& 
Roumen, 1993). Esta situação poderia ser resultante da produção e secreção de compostos tóxicos pelo fungo, que estariam difusos na área ao redor das lesões, ou da desintegração das células da lesão, que impediria o transporte de água e/ou assimilados afetando o tecido ao redor das lesões (Bastiaans, 1991).

Efeitos semelhantes foram obsevados ou sugeridos nos patossistemas Pestalotiopsis mangiferae-mangueira e Septoria tritici-trigo (Shtienberg, 1992), Ascochyta caulina-Chenopodium album (Kempenaar et al., 1996), Colletotrichum lindemuthianum-feijoeiro (Bassanezi et al., 1997; Lopes, 1999), Ascochyta pinodeservilha (Garry et al., 1998; Lucas et al., 1998), Alternaria solani-batata (Shah et al., 1998), Phaeoisariopsis griseola-feijoeiro (Bassanezi, 1995; Canteri, 1998) e Phaeosphaeria maydis-milho (Godoy et al., 1998; Godoy et al., 1999).

Contrariamente, van Oijen (1990) relatou que a fotossíntese não foi reduzida nos tecidos sadios de plantas de batata infectadas com Phytophthora infestans. Neste caso, diferentemente dos estudos previamente mencionados, a assimilação de $\mathrm{CO}_{2}$ foi medida em folhas assintomáticas de plantas doentes e não na área verde de folhas parcialmente doentes.

Fungos que infectam as plantas sistemicamente ocupam os vasos do xilema causam sintomas de murcha. Existem, porém, algumas evidências que, embora a condutância estomática seja reduzida em plantas infectadas com estes fungos, a redução na fotossíntese nem sempre é devida ao estresse hídrico induzido pelo patógeno. Em estudos com plantas de tomate infectadas com Fusarium oxysporum f.sp. lycopersici raça 1 foi observada uma redução na fotossíntese causada em parte pelo aumento da resistência estomática e em parte pelo grande aumento na resistência do mesófilo que ocorreram antes da detecção do déficit hídrico na folha. $\mathrm{O}$ aumento da resistência do mesófilo, neste caso, foi associado com as reduções na respiração e fotorrespiração, mas não com um decréscimo na atividade da RuBP carboxilase (Duniway \& Slatyer, 1971). Entretanto, da análise das curvas de resposta da assimilação de $\mathrm{CO}_{2}(A)$ versus a concentração intercelular de $\mathrm{CO}_{2}(\mathrm{C} i)$ tem sido mostrada que algumas murchas afetam diretamente a eficiência da carboxilação promovida pela enzima Rubisco (Hampton et al., 
1990; Pennypacker et al., 1990). Hampton et al. (1990) concluíram que a menor capacidade fotossintética das folhas de algodoeiro, resultante da infecção por Verticillium dahliae, foi produto de dois mecanismos distintos de patogenicidade. Inicialmente, antes do aparecimento dos sintomas visiveis, a redução da fotossíntese foi dada por processos não estomáticos não mediados diretamente pelo estresse de déficit hídrico. Ao contrário, folhas com sintomas exibiram uma fotossintese reduzida pela combinação dos efeitos de clorose, estresse hídrico e fechamento dos estômatos. Pennypacker et al. (1990), trabalhando com Verticillium albo-atrum em alfafa, indicaram que a redução na quantidade e na atividade da enzima carboxilase (Rubisco) foi o fator responsável pela redução na fotossintese liquida de plantas infectadas ao invés da redução da concentração intercelular de $\mathrm{CO}_{2}$ causada pela menor condutância estomática da folha.

Mouly et al. (1988) e Kombrink \& Hahlbrock (1990) verificaram que as infecções por Sclerotinia sclerotiorum em girassol e P. infestans em batata, respectivamente, ocasionaram a redução nos níveis de RNAm que codificam as subunidades pequenas da Rubisco e, conseqüentemente, a redução nos níveis da enzima nas áreas verdes remanescentes das folhas atacadas. Reduções na atividade inicial, atividade total e porcentagem de ativação da Rubisco em folhas de feijoeiro infectadas com Phaeoisariopsis griseola foram observadas por Stangarlin (1999).

\subsubsection{Fungos biotróficos}

Nem todos fungos biotróficos agem de modo similar em relação aos mecanismos de infecção. Fungos causadores de oídios formam haustórios apenas nas células da epiderme e, assim, carboidratos e outros nutrientes devem passar por estas células antes de serem absorvidos pelo fungo. Por sua vez, agentes causais das ferrugens parasitam as células da epiderme, mesófilo e bainha do feixe vascular e, portanto, têm um acesso mais direto às reservas de carboidratos. Tais diferenças no crescimento dentro da folha podem ter profundas conseqüências nos mecanismos de inibição da fotossíntese (Scholes, 1992). 
De maneira geral, os fungos biotróficos podem causar um estímulo inicial e temporário na taxa fotossintética com posterior declínio da mesma à medida que os sintomas se manifestam. Muitos mecanismos têm sido propostos para explicar a redução na taxa fotossintética em infecções por fungos obrigatórios (Goodman et al., 1986; Scholes, 1992; Shaw, 1963; Lucas, 1998).

A perda do conteúdo de clorofila e outros pigmentos e/ou alterações na função, tamanho ou número dos cloroplastos dos tecidos foliares são comumente relatados em plantas infectadas com patógenos biotróficos causadores de ferrugens (Ahmad et al., 1983; Berghaus \& Reisener, 1985; Berghaus et al., 1987; McGrath \& Pennypacker, 1990; Moerschbacher et al., 1994; Roberts \& Walters, 1988; Scholes \& Farrar, 1985; Scholes \& Farrar, 1986; Scholes \& Farrar, 1987; So \& Thrower, 1976; Stangarlin, 1999; Statler, 1988; Sziráki et al., 1984; Wang, 1961; Zitko et al., 1985), da ferrugem branca (Chou et al., 1995; Tang et al., 1996) e de oídios (Abo-Foul et al., 1996; Magyarosy et al., 1976; Minarcic et al., 1979; Yurina et al., 1993), sendo intimamente correlacionados com a diminuição na taxa fotossintética das folhas infectadas.

Contudo, estudos monitorando a fotossíntese em doenças causadas por fungos biotróficos têm mostrado uma situação mais complicada que a simples redução de clorofila. Reduções na taxa fotossintética proporcionalmente menores (Mignucci \& Boyer, 1979), iguais (Spitters et al., 1990) ou maiores (Bassanezi, 1995; Lopes, 1999; McGrath \& Pennypacker, 1990; Rabbinge et al., 1985; Shtienberg, 1992) que as esperadas pela redução da área foliar verde são relatadas em vários trabalhos envolvendo ferrugens e oídios.

Interferências no transporte de elétrons da membrana tilacóide de cloroplastos têm sido relatadas e associadas à inibição da fotofosforilação não-cíclica e indução da perda de componentes da cadeia de transporte de elétrons em folhas infectadas por ferrugens (Ahmad et al., 1985; Berghaus et al., 1987; Moerschbacher et al., 1994; Montalbini \& Buchanan, 1974; Montalbini et al., 1981; Scholes \& Farrar, 1985; Scholes $\&$ Rolfe, 1996) e oídios (Abo-Foul et al., 1996; Holloway et al., 1992; Magyarosy et al., 1976; Magyarosy \& Malkin; 1978; Yurina et al., 1993). Entretanto, medidas de 
fluorescência de clorofila em folhas de cevada com oídio, causado por Blumeria graminis f.sp. hordei, não mostraram um efeito direto do patógeno na capacidade de transporte de elétrons (Scholes et al., 1990).

A pouca ou nenhuma influência dos patógenos biotróficos no mecanismo de regulação dos estômatos, resistência da camada laminar e resistência do transporte de $\mathrm{CO}_{2}$ no mesófilo tem levado alguns pesquisadores a concluir que o aumento da resistência à carboxilação, causado por alterações metabólicas nos cloroplastos ou mudanças na quantidade do maquinário fotossintético, seja o principal responsável pela redução da taxa fotossintética em folhas de cevada com ferrugem da folha (Owera et al., 1981), soja com oídio (Mignucci \& Boyer, 1979), beterraba com oídio (Gordon \& Duniway, 1982) e trigo com oídio (Rabbinge et al., 1985).

A ribulose-1,5-bifosfato (RuBP) carboxilase/oxigenase, conhecida como Rubisco, e outras enzimas do ciclo de Calvin também podem ser afetadas. A infecção de cevada com B. graminis f.sp. hordei diminuiu a atividade da RuBP carboxilase por unidade de área, a qual foi atribuída a uma redução na quantidade e atividade da enzima (Scholes et al., 1994; Walters \& Ayres, 1984). A atividade de outras enzimas da via pentose fosfato (3-fosfoglicerato-kinase e gliceraldeído-3-fosfato dehidrogenase) foram também reduzidas após a inoculação com oídio. Como resultado desta redução na atividade das enzimas ocorreria, de acordo com Walters \& Ayres (1984), um decréscimo na regeneração da RuBP e, possivelmente, uma redução no armazenamento de vários carboidratos. Roberts \& Walters (1988) encontraram que a atividade da RuBP carboxilase foi reduzida nas áreas de pústulas de ferrugem de folhas de alho-poró infectadas com Puccinia allii. Perdas de proteínas solúveis totais e clorofila foram observadas dentro das áreas de pústulas, mas não nas regiões entre pústulas. Stangarlin (1999) observou uma redução na atividade inicial e total da Rubisco nas áreas entre as pústulas de ferrugem de folhas de feijoeiro infectadas com Uromyces appendiculatus, juntamente com um aumento no teor de clorofila.

$\mathrm{O}$ acúmulo de amido ao redor dos sítios de infecção tem sido observado em folhas de feijoeiro com U. appendiculatus (Sziráki et al., 1984; Wagner \& Boyle, 1995; 
Wang, 1961) e cevada com Puccinia hordei (Scholes \& Farrar, 1987). No caso da ferrugem do feijoeiro, o conteúdo de açúcares redutores, sacarose e amido aumentou nos tecidos infectados no estádio de fleck e depois diminuiu durante a esporulação do fungo (Inman, 1962; Wagner \& Boyle, 1995) estando diretamente relacionado com o aumento da atividade da invertase ácida neste período (Wagner \& Boyle, 1995). Além disso, folhas de feijoeiro com ferrugem apresentaram uma menor capacidade de exportar seus produtos da fotossíntese para outras partes da planta (Livne \& Daily, 1966; Zaki \& Durbin, 1965). Com relação às ferrugens da cevada e do trigo, causadas respectivamente por P. hordei e Puccinia graminis f.sp. tritici, a quantidade de sacarose diminuiu com o desenvolvimento da doença, enquanto a glicose e a frutose aumentaram inicialmente e então decaíram durante a esporulação (Mitchell et al., 1978; Owera et al., 1983). Moerschbacher et al. (1994), trabalhando com a ferrugem do colmo do trigo, assumiram que a invertase do fungo reverteria o metabolismo primário do hospedeiro, hidrolizando a sacarose em hexoses que não podem ser exportadas do tecido infectado da folha, mas podem ser absorvidas pelo fungo. Adicionalmente, criaria-se um dreno dentro da folha infectada redirecionando o fluxo de assimilados para o fungo e acumulando hexoses que por realimentação negativa inibiriam a fotossintese.

Mais recentemente, a inibição da fotossintese por realimentação negativa após o acúmulo de carboidratos tem sido investigada como um possível mecanismo de redução na fotossintese (Chou et al., 1995; Scholes, 1992; Scholes et al., 1994; Tang et al., 1996; Wright et al., 1995a; Wright et al., 1995b). Estudando os patossistemas B. graminis f.sp. hordei-cevada e B. graminis f.sp. tritici, respectivamente, Scholes et al. (1994) e Wright et al. (1995a) observaram um aumento na atividade da invertase ácida das folhas infectadas e, conseqüentemente, um acúmulo de glicose, frutose e sacarose. Estes eventos resultaram na inibição da taxa fotossintética nas folhas infectadas pela perda de atividade e quantidade das enzimas fotossintéticas do ciclo de Calvin (Scholes et al., 1994; Wright et al., 1995b). Estes pesquisadores sugeriram que o refreamento do ciclo de Calvin ocorreu como um resultado da inibição do produto final ou, mais provavelmente, como um efeito direto dos carboidratos na expressão dos genes que codificam as enzimas 
fotossintéticas. Como conseqüência, o transporte de elétrons seria refreado em resposta à reduzida demanda por ATP e NADPH, ocorrendo fotoinibição e acelerada perda de clorofila da folha. Em conclusão, estes patógenos alteraram as relações fonte-dreno na folha

A aumentada atividade da invertase ácida e o acúmulo de carboidratos foram também detectados em folhas de Arabidopsis thaliana infectadas com Albugo candida e estes foram intimamente correlacionados com o decréscimo na fotossíntese, conteúdo de clorofila e atividade da Rubisco nestas folhas (Chou et al., 1995; Scholes \& Rolfe, 1995; Tang et al., 1996).

Oídios parecem estimular a atividade da invertase do seu hospedeiro enquanto que as ferrugens comumente produzem sua própria invertase. As ferrugens, penetrando com seus haustórios nas células da epiderme e mesófilo, estão em contato mais íntimo com a atividade fotossintética das células do mesófilo, enquanto que os oídios, produzindo haustórios apenas nas células da epiderme, têm que redirecionar o fluxo de assimilados num tecido do hospedeiro não penetrado diretamente pelo micélio (Moerschbacher et al., 1994).

\subsubsection{Alterações na respiração de plantas doentes}

O termo respiração refere-se a uma série complexa de reações químicas pelas quais as células liberam energia numa forma que possa ser utilizada em vários processos celulares. A liberação da energia armazenada em carboidratos (amido e açúcares) e ácidos graxos se dá pela sua oxidação em compostos mais simples (Salisbury \& Ross, 1992).

A respiração de uma planta infectada por um patógeno geralmente aumenta, significando que os tecidos doentes passam a utilizar suas reservas de energia (ATP, $\mathrm{NADPH}$, carboidratos e ácidos graxos) mais rápido que o normal para suprir a demanda de energia pelo aumento da atividade metabólica das células da planta (Agrios, 1997; Lucas, 1998). Este aumento na atividade metabólica das células estaria relacionado, 
principalmente, à produção e mobilização de mecanismos de defesa das células, como a síntese de compostos fenólicos pela via pentose fosfato (estimulada em tecidos infectados) e deposição de lignina e suberina para proteção e regeneração de tecidos injuriados (Agrios, 1997; Leite \& Pascholati, 1995; Lucas, 1998). Além destes, Hutcheson \& Buchanan (1983) apontam outros mecanismos que estariam relacionados com o aumento da respiração em tecidos doentes como: (1) desacoplamento do transporte mitocondrial de elétrons da síntese de ATP (fosforilação oxidativa) por ação de toxinas produzidas pelo patógeno, causando o acúmulo de ADP que estimula a respiração; (2) perda da compartimentalização de enzimas e metabólitos-chaves, devido ao aumento da permeabilidade da membrana por ação de toxinas; (3) aumento dos níveis de alguns substratos, como amido e açúcares solúveis, que se acumulam, resultando em bloqueio de translocação.

Embora este aumento ocorra tanto em interações patógeno-hospedeiro compatíveis quanto em incompatíveis, existem evidências que sugerem que em tecidos suscetíveis este aumento na respiração deva ser parte do sistema promotor da doença, enquanto que em tecidos resistentes isto deve ter o efeito oposto, sendo parte do sistema de defesa da planta (Smedegaard-Petersen, 1984). Em geral, a taxa respiratória aumenta após o início da infecção, quando aparecem os sintomas visíveis, e continua aumentando até a fase de multiplicação e esporulação do patógeno, após a qual diminui até os níveis normais, ou abaixo dos observados, nos tecidos sadios (Goodman et al., 1986). Em plantas resistentes a respiração aumenta mais rápido que em plantas suscetíveis, mas também diminui rapidamente após atingir o máximo, enquanto que em plantas suscetíveis a respiração se mantém em níveis mais elevados por mais tempo (Agrios, 1997).

Do mesmo modo, diferentes comportamentos podem ser esperados em plantas infectadas por fungos de acordo com seu comportamento trófico (Lucas, 1998).

Com os fungos biotróficos, a taxa respiratória aumenta regularmente a medida que o patógeno esporula e permanece alta até a senescência dos tecidos. Estes fungos provavelmente agem como um dreno metabólico, causando um incremento no fluxo de nutrientes através da planta, como no caso das ferrugens do feijoeiro (Daly et al., 1961; 
Raggi, 1978; Raggi, 1980), da cevada (Scholes \& Farrar, 1986) e do alho-poró (Roberts $\&$ Walters, 1988) que causaram um aumento significativo na taxa respiratória das folhas infectadas com o início da esporulação do patógeno. Da mesma forma no caso da infecção de cevada por oídio houve um elevado aumento da respiração três dias após a inoculação, mantido até a senescência da folha (Smedegaard-Petersen, 1984). Entretanto, não foram observadas diferenças significativas na taxa de respiração de folhas de aveia infectadas com B. graminis f.sp. avenae (Haigh et al., 1991) e de $A$. thaliana infectadas com A. candida (Chou et al., 1995).

No caso de fungos hemibiotróficos e necrotróficos, o aumento da respiração ocorre logo após o aparecimento dos sintomas, rapidamente atinge um pico e depois diminui até níveis imensuráveis com o avanço da necrose dos tecidos da planta, como no caso da infecção por Pyrenophora teres em cevada na qual a ação de toxinas produzidas pelo fungo provavelmente causam o desacoplamento da fosforilação oxidativa com marcante efeito na permeabilidade das membranas celulares do hospedeiro (SmedegaardPetersen, 1984). Martin, (1986) encontrou semelhante comportamento para o patossistema $R$. secalis-cevada, no qual a respiração após aumentar nas folhas infectadas caiu com o aumento da área necrosada.

Freqüentemente tem sido sugerido que o aumento da taxa respiratória deve-se principalmente à respiração do hospedeiro e que a participação direta do patógeno é negligivel, apesar da extensão na qual o fungo participe não seja ainda clara (Agrios, 1997; Goodman et al., 1986, Lucas, 1998). O aumento da respiração pelas folhas doentes contribui para a diminuição da fotossintese líquida da folha e aumento do ponto de compensação no qual o balanço entre a assimilação e liberação de $\mathrm{CO}_{2}$ é nulo (Owera et al., 1981; Raggi, 1978 e 1980).

\subsubsection{Alterações na transpiração e condutância estomática de plantas doentes}

A transpiração é o processo em que a folha perde água na forma de vapor. Esta perda de água ajuda a controlar a temperatura foliar e gera uma força eletromotriz que 
movimenta a água dentro da planta. A cutícula foliar, quase que totalmente impermeável à passagem de água, praticamente impede a transpiração. Em torno de 90-95 \% da taxa de transpiração acabam sendo controlados pelos estômatos. A abertura dos estômatos, que representa a condutância estomática à difusão dos gases, é controlada por diversos fatores ambientais (luminosidade, temperatura, concentração externa e interna de $\mathrm{CO}_{2}$, umidade relativa do ar, disponibilidade de água no solo, vento), da planta (ritmos de abertura, fenologia, potencial hídrico da folha, fitohormônios, freqüência estomática, tamanho dos estômatos) e injúrias causadas por fatores bióticos e abióticos (Salisbury \& Ross, 1992).

Em doenças de plantas nas quais o patógeno infecta a folha, a transpiração pode aumentar, diminuir ou permanecer inalterada. $\mathrm{O}$ aumento da perda de água pode ser acelerado pela destruição de parte da proteção fornecida pela cutícula, pelo aumento da permeabilidade da membrana das células da folha e pela inibição do fechamento dos estômatos (Lucas, 1998; McGrath \& Pennypacker, 1990; Shtienberg, 1992). Se a absorção e translocação não conseguirem vencer a excessiva perda de água ocorrerá a perda de turgor e a murcha da folha. As forças de sucção de folha com transpiração excessiva são aumentadas anormalmente e podem levar ao colapso ou disfunção dos vasos pela produção de tiloses e gomas (Agrios, 1997). Por outro lado, a perda de água pode ser reduzida, resultante do fechamento induzido dos estômatos pela doença, redução dos espaços do mesófilo pelas hifas ou hipertrofia das células do mesófilo, obstrução dos tecidos condutores e estômatos, desfolha e/ou murcha e seca precoce das folhas transpirantes (McGrath \& Pennypacker, 1990; Shtienberg, 1992).

Cayon et al. (1996) atribuem a redução da condutância estomática de folhas de bananeira infectadas com Mycosphaerella fijiensis à perda da capacidade da folha regular a abertura e o fechamento dos estômatos pela penetração mecânica dos fungo através dos mesmos.

Plantas de cevada infectadas com $R$. secalis tiveram a transpiração aumentada em relação às plantas sadias quando no escuro ou em baixa luminosidade, porém em alta luminosidade a transpiração das plantas doentes foi menor que das sadias (Martin, 1986). 
Com a evolução dos sintomas, a condutância estomática diminuiu e a resistência do mesófilo à difusão de $\mathrm{CO}_{2}$ aumentou. Aumentos na resistência do mesófilo nas folhas doentes provavelmente resultam da interrupção de processos fotoquímicos e bioquímicos, bem como de outros processos relacionados à transferência física do $\mathrm{CO}_{2}$ ao nível celular.

Ephrath et al. (1989) observaram também uma redução na transpiração de folhas de algodoeiro infectadas com $A$. alternata, porém esta redução foi menor que a que seria esperada pelo tamanho da lesão necrótica sozinha, talvez pela perda incontrolada de água através dos estômatos que perderam sua capacidade de fechar ou pelo efeito de toxinas produzidas nas folhas doentes, que estariam além das lesões e afetariam a transpiração, assim como a fotossintese do restante da folha.

Comparando diversos patossistemas, Shtienberg (1992) observou reduções na taxa de transpiração das plantas hospedeiras para todas doenças consideradas. Reduções proporcionais à redução da área foliar verde foram observadas para todos patógenos necrotróficos causadores de manchas foliares (A. alternata, S. tritici e $P$. mangiferae). Resultado semelhante foi relatado por Godoy et al. (1999) no patossistema P. maydismilho. Nestes casos, a destruição das células é diretamente relacionada à presença do fungo e partes não colonizadas da folha permanecem normalmente ativas.

Entretanto, no patossistema $C$. lindemuthianum-feijoeiro, foi observada uma drástica redução da transpiração nas folhas doentes maior que a explicada pela área ocupada pelas lesões (Bassanezi et al., 1997). Neste caso, a ruptura e colapso dos vasos condutores pelo patógeno estaria afetando a transpiração em regiões da folha em que o patógeno ainda não estaria presente.

No caso de fungos biotróficos, tanto o aumento quanto a redução da transpiração de plantas infectadas são relatados. Shtienberg (1992) relata reduções proporcionalmente maiores que a esperada pela redução da área verde nas folhas infectadas por oídios, como B. graminis f.sp. tritici, Leveillula taurica, Sphaerotheca pannosa e Uncinula necator, enquanto que Mignucci \& Boyer (1979) observaram o oposto para folhas de soja com Microsphaera diffusa. No caso de ferrugens, reduções proporcionalmente menores que a esperada pela redução da área verde nas folhas 
infectadas foram observadas por Shtienberg (1992). No caso das ferrugens estudadas, causadas por Puccinia recondita f.sp. tritici e Puccinia sorghi, em severidades menores que $10 \%$, foram observadas taxas de transpiração maiores que as de folhas sadias. A intensificação das taxas de transpiração causadas por fungos causadores de ferrugens tem sido atribuída à ruptura da epiderme pelo patógeno e não por danos ao mecanismo de abertura e fechamento dos estômatos (Duniway \& Durbin, 1971; Owera et al., 1981). Entretanto, em níveis maiores de severidade, as folhas infectadas transpiraram menos que as folhas não infectadas, mas o declínio da transpiração foi menor que o que seria esperado com base na redução da área foliar sem sintomas (Shtienberg, 1992). Folhas de trigo com $P$. recondita e $P$. graminis f.sp. tritici apresentaram menores taxas de transpiração e maiores resistências estomáticas conforme o aumento da severidade de doença (McGrath \& Pennypacker, 1990).

Contudo, a contribuição do aumento da resistência estomática provocada por patógenos biotróficos na redução da fotossíntese líquida de folhas infectadas tem sido considerada muito baixa quando comparada com efeitos mais diretos no processo fotossintético como o aumento da resistência à carboxilação e redução do conteúdo de clorofila (McGrath \& Pennypacker, 1990; Mignucci \& Boyer, 1979; Owera et al., 1981; Rabbinge et al., 1985; Statler, 1988).

\subsubsection{Avaliação da fotossíntese, respiração, transpiração e condutância estomática in vivo}

Os métodos mais comumente usados para a avaliação da fotossíntese, respiração, transpiração e condutância estomática in vivo na última década são as medidas de trocas gasosas e a emissão de fluorescência da clorofila $\boldsymbol{a}$. 


\subsubsection{Sistema de trocas gasosas}

A avaliação da atividade fotossintética tem sido usualmente realizada pela avaliação da taxa de assimilação de $\mathrm{CO}_{2}$ pela folha mantida sob determinada condição de iluminação, que fornece uma medida direta da taxa líquida de fotossíntese. Quando a folha é mantida no escuro, ao invés da assimilação de $\mathrm{CO}_{2}$, o que se mede é a liberação de $\mathrm{CO}_{2}$ pela respiração da folha (Long \& Hällgren, 1993). Quanto maior a assimilação de $\mathrm{CO}_{2}$ pela folha, maior sua atividade fotossintética, e quanto maior a liberação de $\mathrm{CO}_{2}$ pela folha, maior sua atividade respiratória. Qualquer mudança na atividade fotossintética ou respiratória da folha será refletida na concentração final de $\mathrm{CO}_{2}$ medida.

A maioria do estudos de troca de $\mathrm{CO}_{2}$ tem envolvido métodos em que as folhas ficam confinadas em câmaras transparentes e a taxa de assimilação de $\mathrm{CO}_{2}$ é determinada pela medição da mudança da concentração de $\mathrm{CO}_{2}$ no ar que atravessa a câmara. Nos sistemas usados, o ar passa dentro de um analisador de gás a infra-vermelho (IRGA) que continuamente registra a concentração de $\mathrm{CO}_{2}$ no sistema, verificando a diferença entre o ar que atravessa a câmara com a folha e o ar que entra na câmara. A taxa de assimilação ou liberação de $\mathrm{CO}_{2}$ é expressa como a quantidade de $\mathrm{CO}_{2}$ assimilado ou liberado por unidade de área foliar e tempo $\left(\mu \mathrm{mol} \mathrm{CO}_{2} \mathrm{~m}^{-2} \mathrm{~s}^{-1}\right)$.

As variáveis que comumente são obtidas por sistemas de trocas gasosas são a taxa fotossintética (iluminada), taxa respiratória (no escuro), taxa de transpiração, concentração intercelular de $\mathrm{CO}_{2}$ e condutância ou resistência estomática. Os cálculos destas variáveis são baseados nos modelos desenvolvidos por Farquar e seu grupo (Farquar et al., 1980; Farquar \& von Caemmerer, 1982) e ainda são a base para a interpretação das avaliações de trocas gasosas. Relações entre a assimilação de $\mathrm{CO}_{2}(A)$ com fatores externos, como a intensidade de luz incidente, temperatura ambiente e concentração de $\mathrm{CO}_{2}$ ambiente, permitem avaliar quantitativamente os efeitos destes fatores em diferentes passos do processo de fotossintese. Por exemplo, o coeficiente angular inicial da curva de assimilação versus a concentração intercelular de $\mathrm{CO}_{2}(\mathrm{~A} / \mathrm{C} i)$ reflete a atividade da Rubisco; a assimilação de $\mathrm{CO}_{2}$ na luz saturante e na concentração 
de $\mathrm{CO}_{2}$ saturante é assumida ser limitada pela taxa potencial de regeneração do substrato da carboxilação (RuBP). Posteriormente, o coeficiente angular inicial da curva que relaciona $A$ versus a luz incidente é uma estimativa da eficiência máxima de uso da luz ou eficiência quântica da reação luminosa da fotossíntese. A taxa de assimilação na luz saturante é considerada uma medida da capacidade fotossintética da folha (Beyschlag \& Ryel, 1998; Farquar \& Sharkey, 1982; Long \& Hällgren, 1993).

\subsubsection{Emissão da fluorescência da clorofila $a$}

Como resultado do desenvolvimento de instrumentos e métodos mais modernos de análise da emissão de fluorescência, esta tornou-se uma opção muito atrativa para obter informações rápidas, semi-quantitativas e não invasivas sobre a atividade fotossintética das plantas (van Kooten \& Snel, 1990).

No aparato fotossintético, a molécula de clorofila $a$ absorve luz e se torna excitada a um estado maior de energia. A molécula excitada não é estável e os elétrons retornam rapidamente ao estado inicial de energia liberando a energia do fóton basicamente de três formas: (1) a energia de excitação destas moléculas pode ser transferida por ressonância à outra molécula aceptora, resultando no transporte de elétrons fotossintético; (2) pode liberar parte da energia de excitação como calor; (3) pode emitir o resto da energia como fluorescência (Krause \& Weis, 1991). Como os processos de de-excitação das moléculas de clorofila são competitivos, mudanças na taxa fotossintética e/ou na emissão de calor dissipado irão causar mudanças complementares na intensidade da fluorescência emitida (Bolhàr-Nordenkampf \& Öquist, 1993).

Sob condições de baixa luminosidade, aproximadamente $97 \%$ dos fótons ou quanta absorvidos são usados nas reações fotoquímicas, 2,5 \% são transformados em calor e $0,5 \%$ são reemitidos como luz vermelha fluorescente. Nesta situação, diz-se que todos os centros de reação estão abertos (oxidados) e a produção de fluorescência é mínima $\left(F_{0}\right)$. Se todos os centros de reação estão fechados (reduzidos), 95-97\% da energia absorvida pode ser eliminada via calor e 2,5-5,0 \% via fluorescência. Diz-se que, 
neste caso, a emissão de fluorescência é máxima $\left(F_{\mathrm{m}}\right)$ (Bolhàr-Nordenkampf \& Öquist, 1993). À temperatura ambiente, a maioria da fluorescência é emitida das moléculas de clorofila $a$ associadas com o fotossistema II (PSII) e assim a produção de fluorescência é relacionada à eficiência do transporte de elétrons pelo PSII (Krause \& Weis, 1991).

A produção de fluorescência in vivo é diminuída por fundamentalmente dois mecanismos diferentes denominados mecanismos de "quenching". Comumente a extensão do "quenching" é expressa por coeficientes de "quenching" que indicam a proporção diminuída da fluorescência máxima, variando o valor do "quenching" de 0 a 1 (Krause \& Weis, 1991).

O primeiro tipo de "quenching" ocorre devido à competição com as reações fotoquímicas, chamado de "quenching" fotoquímico ou $q P$. Para que ocorram as reações fotoquímicas, o primeiro aceptor de elétrons estável do PSII, a plastoquinona $A\left(Q_{A}\right)$, deve estar no estado oxidado. O $q P$ denota a proporção de "excitons" capturados e que são convertidos em energia química nos centros de reação do PSII. A re-oxidação da $\mathrm{Q}_{\mathrm{A}}$ causa, então, a diminuição na produção de fluorescência, pois neste estado, a $Q_{A}$ receberá os elétrons e diminuirá a quantidade de energia que será reemitida como fluorescência. $\mathrm{O}$ segundo tipo de "quenching", denominado de "quenching" não-fotoquímico ou qNP, é relacionado com a energização da membrana tilacóide e seus processos associados. A maior parte do $q N P$ é ligado à formação do gradiente transtilacóide de $\Delta \mathrm{pH}$ e à acidificação do lúmen da tilacóide que ocorre na luz, e é chamado de "quenching" dependente de energia ou $q E$. Outro importante componente do $q N P$ é o "quenching" fotoinibitório ou $q I$ relacionado com a fotoinibição da fotossíntese (Krause \& Weis, 1991).

A fluorescência da clorofila apresenta mudanças características na sua intensidade, denominadas de efeito Kautsky, que seguem a indução da fotossíntese em folhas pré-adaptadas no escuro. Após a iluminação, a assimilação de $\mathrm{CO}_{2}$ tem que ser ativada e inicia lentamente um período de indução que vai acelerando até uma taxa estável. Desta forma, no estágio inicial da indução da fotossíntese, a eficiência do PSII é muito baixa. Quando uma irradiação contínua é aplicada, a produção de fluorescência 
cresce rapidamente até um pico e diminui lentamente devido ao "quenching" da fluorescência pelos processos associados com a fotossíntese (Foyer, 1993). Com o uso da metodologia de Schrieber et al. (1986) é possível a determinação e o cálculo das várias variáveis de fluorescência.

$\mathrm{O}$ valor de $F_{\mathrm{v}} / F_{\mathrm{m}}$, obtido pela equação $\left(F_{\mathrm{m}}-F_{0}\right) / F_{\mathrm{m}}$, é a medida da eficiência máxima do PSII e representa a eficiência de captura da energia de excitação pelos centros de reação do PSII, variando de 0,75 a 0,85 entre folhas sadias e não estressadas de diferentes espécies e ecótipos (Bolhàr-Nordenkampf \& Öquist, 1993; Krause \& Weis, 1991). Efeitos ambientais de longa duração freqüentemente resultam em fotoinibição crônica (Osmond, 1994), que se manifesta pela redução da taxa $F_{\mathrm{v}} / F_{\mathrm{m}}$. Esta suscetibilidade intrínseca do PSII à fotoinibição fornece uma medida valiosa do grau de estresse ao qual a planta ou o fotossistema foi submetido e como a planta responde ao seu ambiente (Foyer, 1993).

Existe uma relação aproximadamente linear entre a produção quântica da evolução de $\mathrm{O}_{2}$ e a taxa $F_{\mathrm{v}} / F_{\mathrm{m}}$, e posteriormente foi demonstrada uma boa correlação entre a produção quântica do transporte de elétrons do PSII e a produção quântica da evolução de $\mathrm{O}_{2}$ (Genty et al., 1989). Finalmente, medições de fluorescência podem ser extrapoladas para dar estimativas de fluxo através da assimilação de carbono e outros ciclos (Cornic \& Briantais, 1991).

Desta forma, a fluorescência da clorofila $a$ tem fornecido informações sobre quase todos os aspectos da fotossíntese e respostas das plantas a vários fatores de estresse. Mais recentemente, os dados de emissão de fluorescência pela clorofila $a$ também têm sido usados para estudos da ação de patógenos sobre a atividade do PSII e mudanças no metabolismo fotossintético de folhas doentes (Abo-Foul et al., 1996; Ahmad et al., 1985; Berghaus et al., 1987; Lopes, 1999; Moll et al., 1995; Peterson \& Aylor, 1995; Raggi, 1995; Santos et al., 1998; Schnabel et al., 1998; Scholes \& Farrar, 1985; Scholes \& Rolfe, 1995; Scholes \& Rolfe, 1996; Wright et al., 1995b; Yurina et al., 1993; Yurina et al., 1996). 


\subsection{Avaliação de danos e eficiência fotossintética de plantas doentes}

Estimativas confiáveis dos prejuízos causados pelos patógenos são prérequisitos para o desenvolvimento de qualquer programa bem sucedido de controle de doenças, independentemente do método a ser utilizado (Zadoks \& Schein, 1979). A quantificação de danos é, portanto, um ponto chave na definição de qualquer estratégia ou tática de controle (Bergamin Filho et al., 1995).

Modelos empíricos de danos são comumente usados para estabelecer uma relação entre a intensidade de doença e a redução na produção. Entretanto, esta relação é comumente inconsistente, primeiramente porque a máxima produção possível varia para cada campo, localidade e estação de cultivo devido a diferenças nos fatores edafoclimáticos. Também, como apontam Waggoner \& Berger (1987), porque a severidade de doença, considerada isoladamente, interfere de modo diferente caso ocorra precoce ou tardiamente na plantação, ou porque não é considerada a desfolha, ou porque a área foliar das plantas é ignorada, ou porque a produção depende da área sadia, fotossintetizante, das folhas (Monteith \& Elston, 1983; Squire, 1990) e não da área doente ocupada pelo patógeno. Os métodos de quantificação de doença, ao contrário, têm colocado o hospedeiro num segundo plano e privilegiado o patógeno (Lopes et al., 1994).

Alternativamente, a abordagem mecanística para modelos de danos descreveria os vários processos fisiológicos do crescimento da planta e incorporaria os efeitos das doenças nestes processos, usualmente como modelos de simulação. O uso de modelos mecanísticos é de suma importância para um entendimento pleno da resposta da produção à doença (Gaunt, 1987; Loomis et al., 1979; Loomis \& Adams, 1983).

Boote et al. (1983), de acordo com o efeito nos processos relacionados ao fluxo de carbono na cultura, classificaram as pragas e patógenos em sete categorias: consumidores de tecidos, aceleradores da senescência foliar, redutores de estande, ladrões de luz, redutores da taxa fotossintética, consumidores de assimilados e redutores de turgor. As primeiras quatro categorias representariam os principais efeitos das pragas 
e patógenos na interceptação da radiação pelas folhas, e as três últimas representariam os principais efeitos na eficiência de uso da radiação absorvida (Johnson, 1987). A quantificação destes efeitos de patógenos no crescimento da cultura tornaria possível acoplá-los em simuladores para prever reduções na produção.

Watson (1947), em estudos fisiológicos no crescimento de culturas, encontrou alta correlação entre produção e a quantidade de área foliar disponível, mais especificamente com o índice de área foliar (LAI) e propôs, mais tarde (Watson, 1952), que a produção correlaciona-se ainda melhor com a duração da área foliar ( $L A D)$, definida como a integral em função do tempo do índice de área foliar. Pesquisas mais recentes observaram que a produção está mais diretamente relacionada com a quantidade de insolação que as plantas são capazes de usar durante a estação de cultivo (CharlesEdwards, 1982; Gallagher \& Biscoe, 1978; Monteith, 1972; Monteith, 1981). Mais correlacionada com a produção que a $L A D$ seria, portanto, a variável absorção da área foliar $(L A A)$ que considera a quantidade de luz realmente absorvida pela folhagem (Lopes et al., 1994).

Waggoner \& Berger (1987) propuseram juntar aos conceitos fisiológicos desenvolvidos por Watson (1947), Gallagher \& Biscoe (1978), Charles-Edwards (1982) e Monteith \& Elston (1983) os efeitos da doença sobre a folhagem das plantas hospedeiras. Para relacionar a curva de progresso da doença ao crescimento da planta é necessário subtrair a área foliar doente da $L A D$ por meio da integração da área foliar sadia e operacional durante o período de crescimento do hospedeiro $[(1-x) L A I]$. Esta integração resulta no que chamam de duração da área foliar sadia $(H A D)$. Adaptação semelhante pode ser feita com relação à variável $L A A$, excluindo a área foliar doente para calcular o que chamam de absorção da área foliar sadia (HAA).

Madden (1993) comenta que a substituição da severidade de doença $(x)$ pela duração da área foliar sadia $(H A D)$ ou pela absorção da área foliar sadia $(H A A)$, proposta por Waggoner \& Berger (1987), nos modelos de danos está levando a uma maior compreensão das relações doença-dano, sendo válida em diferentes patossistemas, tais como P. infestans em batata (Haverkort \& Bicamumpaka, 1986; Rotem et al., 1983a; 
Rotem et al., 1983b; van Oijen, 1990), A. solani em batata (Jonhson \& Teng, 1990; Shah et al., 1998), Aschochyta sp. em Vicia faba (Madeira et al., 1988), P. grisea em arroz (Pinnschmidt \& Teng, 1993), B. graminis f.sp. tritici em trigo (Daamen \& Jorritsma, 1990), C. lindemuthianum em feijão (Gianasi, 1999; Nunes \& Bergamin Filho, 1996; Silva et al., 1998a), U. appendiculatus em feijão (Iamauti, 1995; Silva et al., 1998a), $P$. griseola em feijão (Bergamin Filho et al., 1997; Canteri, 1998; Carneiro et al., 1997; Silva et al., 1998a) e vírus do mosaico dourado do feijoeiro em feijão (Bianchini, 1998).

Johnson (1987), depois de enfatizar o lado positivo da proposta de Waggoner \& Berger (1987) para quantificar danos, menciona que, para algumas doenças, não só as variáveis $H A D$ e $H A A$, que representam a quantidade de radiação interceptada pela porção verde da planta, são importantes para determinar a produção, mas também a eficiência de conversão desta radiação, chamada por ele de RUE (eficiência do uso da radiação). Para Johnson (1987), a produtividade de uma cultura $w$ pode ser expressa pela relação $w=R I \times R U E$ onde, $R I$ é chamada de interceptação da radiação solar e é equivalente à variável que, integrada, dá origem a $H A A[(1-x)(1-\exp (-k L A I)]$. Johnson (1987) argumenta que RUE é tão importante quanto $R I$ na determinação de $w$. No entanto, Daamen \& Jorritsma (1990) e Ayres (1992) advertem que uma eficiência de conversão menor fatalmente leva a um dossel menor que, por sua vez, interceptará menos luz, confundindo, assim, causas e efeitos.

É essencial, portanto, que um conhecimento detalhado deste aspecto fisiológico da interação patógeno-hospedeiro esteja disponível e seja incorporado em simuladores e em modelos de crescimento da cultura antes que recomendações baseadas em considerações econômicas possam ser prescritas. A despeito disso, no contexto do manejo integrado de doença, é importante identificar aqueles patógenos que causam uma redução da $R U E$ nos tecidos sadios de plantas doentes (Bastiaans, 1991).

De modo geral, a determinação da $R U E$ tem sido feita em condições de campo, utilizando-se parcelas com diferentes níveis de doença, por meio da estimativa do coeficiente angular da reta que relaciona $H A A$ e produção. Caso os coeficientes angulares forem constantes para as diversas situações, considera-se que a $R U E$ não é afetada pelo 
patógeno como nos mostram Aquino et al. (1992) Haverkort \& Bicamumpaka (1986) e Waggoner \& Berger (1987). Por outro lado, usando esta metodologia, o efeito na $R U E$ tem sido demonstrado para $A$. solani em batata (Shah et al., 1998) e $P$. griseola em feijoeiro (Canteri, 1998).

Van Oijen (1990), no entanto, considera que a constância dos coeficientes angulares não é evidência conclusiva para esta hipótese, uma vez que a produção de uma parcela é influenciada por muitos fatores alheios ao problema, como as variações sazonais na interceptação da luz, na fotossíntese das folhas, na respiração e na partição de assimilados, concluindo que somente medições diretas das taxas de fotossíntese em plantas sadias e doentes podem mostrar se a atividade da área foliar verde está sendo afetada pela doença.

Alguns trabalhos têm descrito a relação quantitativa entre intensidade de doença e mudança na taxa de fotossíntese. Os autores que adentraram neste tema observaram que nem sempre a estimativa visual da quantidade de doença indica adequadamente o efeito do patógeno na atividade fotossintética. Segundo Shtienberg (1992), três diferentes padrões de resposta do hospedeiro podem ser observados nas folhas doentes: o decréscimo na atividade fotossintética é proporcional, proporcionalmente maior, ou proporcionalmente menor que a redução correspondente da área foliar sadia devido à doença.

Reduções proporcionalmente menores na atividade fotossintética que a redução correspondente da área foliar sadia devido à doença foram relatadas para os patossistemas Peronospora tabacina-fumo (Cruickshank \& Rider, 1961) e M. diffusasoja (Mignucci \& Boyer, 1979). Somente $P$. recondita $\mathrm{f}$.sp. tritici foi relatada até o momento em não alterar a fotossíntese da área verde remanescente da folha doente, afetando apenas a $R I$ da folha (Spitters et al., 1990), mas trabalhos posteriores demonstraram que a $R U E$ também seria afetada por este patógeno (McGrath \& Pennypacker, 1990; Shtienberg, 1992). Na verdade, a grande maioria dos trabalhos tem relatado decréscimos proporcionalmente maiores na atividade fotossintética que a redução correspondente da área foliar sadia devido à doença. Redução de $R I$ e $R U E$ 
foram relatados para os patossistemas $C$. arachidicola e $C$. personatum-amendoim (Boote et al., 1980; Bourgeois \& Boote, 1992), R. secalis-cevada (Martin, 1986), A. alternata-algodoeiro (Ephrath et al., 1989; Shtienberg, 1992), B. graminis f.sp. triticitrigo (Rabbinge et al., 1985; Shtienberg, 1992), P. graminis f.sp. tritici-trigo (McGrath \& Pennypacker, 1990), E. turcicum-milho (Levy \& Leonard, 1990), P. grisea-arroz (Bastiaans, 1991; Bastiaans, 1993; Bastiaans \& Roumen, 1993), P. mangiferaemangueira, $S$. tritici-trigo, P. sorghi-milho, P. cubensis-abobrinha, L. taurica-pimenta, $U$. necator-videira, S. pannosa-pessegueiro (Shtienberg, 1992), Xanthomonas campestris pv. phaseoli-feijoeiro (Goodwin, 1992), A. caulina-Chenopodium album (Kempenaar et al., 1996), C. lindemuthiamum-feijoeiro (Bassanezi et al., 1997; Lopes, 1999), A. pinodes-ervilha (Garry et al., 1998; Lucas et al., 1998), P. maydis-milho (Godoy et al., 1998; Godoy et al., 1999), U. appendiculatus-feijoeiro (Lopes, 1999) e Xanthomonas campestris pv. oryzae-arroz (Elings et al., 1999).

Bastiaans (1991) propõe uma generalização interessante e útil que permite a classificação de patógenos de acordo com sua habilidade em afetar a $R U E$ de seus hospedeiros. O conceito é baseado na relação entre lesão visual (proporção de área foliar visualmente doente) e lesão virtual (proporção de área foliar imaginária, igual ou superior à visual, dependendo do efeito do patógeno na $R U E$ ). Esta relação é obtida pela equação $y=1-(1-x)^{\beta}$ onde, $y$ representa a lesão virtual, $x$, a lesão visual e $\beta$, a relação entre as proporções de área foliar visual e virtual. A determinação experimental de $\beta$ é conseguida por meio da fórmula $P_{x} / P_{o}=(1-x)^{\beta}$ onde, $P_{x}$ representa a fotossíntese de uma folha com $x$ de severidade de doença e $P_{o}$, a fotossíntese de uma folha sadia. Valores de $\beta$ não diferentes da unidade indicam que $R U E$ não é afetada pelo patógeno e valores superiores indicam, proporcionalmente, reduções em $R U E$.

Para Bastiaans (1991), a determinação da relação entre a RUE do tecido foliar verde e a severidade de doença, isto é, a quantificação de $\beta$ para os diferentes patossistemas, tem grande importância para a proteção de plantas quando a definição de funções de dano for o objetivo final. 


\section{ALTERAÇÕES NA FOTOSSÍNTESE, RESPIRAÇÃO E TRANSPIRAÇÃO DAS FOLHAS DE FEIJOEIRO INFECTADAS COM Uromyces appendiculatus, Phaeoisariopsis griseola E Colletotrichum lindemuthianum DURANTE O DESENVOLVIMENTO DAS DOENÇAS}

\subsection{Resumo}

Neste trabalho foram observadas e quantificadas as alterações na fotossíntese, respiração e transpiração nas folhas de feijoeiro, provocadas pela ferrugem, mancha angular e antracnose, durante o processo de desenvolvimento das doenças. Medidas relacionadas às trocas gasosas e emissão de fluorescência da clorofila $a$ foram tomadas em folhas de feijoeiro sadias e inoculadas com os agentes causais destas doenças foliares no decorrer do processo infeccioso. Os experimentos foram realizados em duas cultivares de feijoeiro sob condições de ambiente controlado, testando diferentes temperaturas. Todas as doenças causaram reduções na taxa fotossintética líquida e aumento da respiração nas folhas infectadas a partir do aparecimento dos primeiros sintomas. As diferenças entre as plantas sadias e doentes foram crescentes com o desenvolvimento das doenças. A taxa de transpiração e a condutância estomática tiveram o mesmo comportamento, sendo pouco alteradas nas folhas com ferrugem e reduzidas da mesma forma que a taxa fotossintética líquida nas folhas com mancha angular e nas folhas com antracnose. A resistência à carboxilação foi o principal fator relacionado com a redução da eficiência fotossintética nas áreas aparentemente sadias das folhas com ferrugem e das folhas com mancha angular, enquanto que a redução da concentração de $\mathrm{CO}_{2}$ intercelular devido à maior resistência estomática foi o principal fator nas folhas com antracnose. Decréscimos na emissão de fluorescência da clorofila $a$ foram observados nas folhas 
doentes para todas as doenças acompanhando a diminuição da assimilação de $\mathrm{CO}_{2}$ e o aumento da severidade das doenças. A fluorescência mínima só foi reduzida significativamente nas folhas com mancha angular, mas a fluorescência máxima foi reduzida nas folhas com qualquer uma das doenças, como também a eficiência quântica do fotossistema II. Uromyces appendiculatus causou alterações mais amenas nos mecanismos de regulação dos processos fisiológicos da folha doente, enquanto que Phaeoisariopsis griseola e Colletotrichum lindemuthianum foram mais agressivos.

\subsection{Introdução}

A invasão da planta hospedeira por um patógeno leva, cedo ou tarde, a alterações nos seus diversos processos fisiológicos, incluindo a respiração, fotossíntese, translocação de nutrientes e água, transpiração e regulação de crescimento. Uma análise destas mudanças durante e após a infecção da planta hospedeira pelo patógeno pode esclarecer os modos pelos quais os patógenos causam doença e ajudar a elucidar os mecanismos pelos quais as plantas resistem ao ataque dos patógenos (Lucas, 1998). Além disso, o conhecimento e a quantificação dos efeitos das doenças nos processos fisiológicos do hospedeiro vêm se tornando importantes para a sua incorporação em modelos de crescimento da cultura (McGrath \& Pennypacker, 1990) e para o desenvolvimento do manejo integrado de doenças (Shtienberg, 1992).

Um grande número de trabalhos, realizados com diversos patossistemas, vem mostrando que a redução na taxa fotossintética líquida da folha do hospedeiro, após sua infecção um patógeno fúngico, pode ser causada por um decréscimo na área foliar fotossintetizante e/ou pela redução na eficiência fotossintética desta área foliar (Abo-Foul et al., 1996; Ahmad et al., 1983; Ahmad et al., 1985; Bassanezi, 1995; Bassanezi et al., 1997; Bastiaans, 1991; Berghaus \& Reisener, 1985; Berghaus et al., 1987; Boote et al., 1980; Bourgeois \& Boote, 1992; Chou et al., 1995; Ephrath et al., 1989; Garry et al., 1998; Godoy et al., 1998; Godoy et al., 1999; Gordon \& Duniway, 1982; Holloway et al., 1992; Kempenaar et al., 1996; Levy \& Leonard, 1990; Livne, 1964; Lopes, 1999; 
Magyarosy et al., 1976; Magyarosy \& Malkin; 1978; Martin, 1986; McGrath \& Pennypacker, 1990; Mignucci \& Boyer, 1979; Minarcic et al., 1979; Moerschbacher et al., 1994; Montalbini \& Buchanan, 1974; Owera et al., 1981; Rabbinge et al., 1985; Raggi, 1978; Raggi, 1980; Roberts \& Walters, 1988; Scholes, 1992; Scholes et al., 1990; Scholes et al., 1994; Scholes \& Farrar, 1985; Scholes \& Farrar, 1986; Scholes \& Farrar, 1987; Scholes \& Rolfe, 1996; Shaw, 1963; Shtienberg, 1992; So \& Thrower, 1976; Spitters et al., 1990; Statler, 1988; Tang et al., 1996; Walters \& Ayres, 1984; Wright et al., 1995a; Wright et al.,1995b; Yurina et al., 1993).

A respiração da folha geralmente aumenta após a infecção, como observado em vários patossistemas (Daly et al., 1961; Hutcheson \& Buchanan, 1983; Martin, 1986; Owera et al., 1981; Raggi, 1978; Raggi, 1980; Roberts \& Walters, 1988; Scholes \& Farrar, 1986; Smedegaard-Petersen, 1984), indicando que os tecidos doentes passam a utilizar com maior rapidez as suas reservas de energia para suprir a demanda devido ao aumento da atividade metabólica das células da planta (Agrios, 1997; Lucas, 1998).

Em doenças de plantas nas quais o patógeno infecta a folha, o aumento da transpiração pode ser acelerado pela destruição de parte da proteção fornecida pela cutícula, pelo aumento da permeabilidade da membrana das células da folha e pela inibição do fechamento dos estômatos. Por outro lado, a redução da transpiração pode ser resultante do fechamento induzido dos estômatos pela doença, redução dos espaços do mesófilo pelas hifas ou hipertrofia das células do mesófilo, obstrução dos tecidos condutores e estômatos, desfolha e/ou murcha e seca precoce das folhas transpirantes (Bassanezi et al., 1997; Cayon et al., 1996; Duniway \& Durbin, 1971; Ephrath et al., 1989; Godoy et al., 1999; Martin, 1986; McGrath \& Pennypacker, 1990; Mignucci \& Boyer, 1979; Owera et al., 1981; Shtienberg, 1992).

Os métodos comumente usados, na última década, para a avaliação das alterações na fotossintese, respiração e transpiração causadas por patógenos in vivo são as medidas de trocas gasosas e a emissão de fluorescência da clorofila $a$. As variáveis normalmente obtidas por sistemas de trocas gasosas são a taxa de assimilação ou liberação de $\mathrm{CO}_{2}$, taxa de transpiração, concentração intercelular de $\mathrm{CO}_{2}$ e condutância 
estomática (Long \& Hällgren, 1993). Os dados de emissão de fluorescência pela clorofila $a$, por sua vez, têm sido usados para estudos da ação de patógenos sobre a atividade do fotossistema II e mudanças no metabolismo fotossintético de folhas doentes (Abo-Foul et al., 1996; Ahmad et al., 1985; Berghaus et al., 1987; Lopes, 1999; Moll et al., 1995; Peterson \& Aylor, 1995; Raggi, 1995; Santos et al., 1998; Schnabel et al., 1998; Scholes

\& Farrar, 1985; Scholes \& Rolfe, 1995; Scholes \& Rolfe, 1996; Wright et al., 1995b; Yurina et al., 1993; Yurina et al., 1996).

Com o objetivo de observar e quantificar as alterações na fotossintese, respiração e transpiração em folhas de feijoeiro provocadas pela ferrugem (Uromyces appendiculatus), mancha angular (Phaeoisariopsis griseola) e antracnose (Colletotrichum lindemuthianum), medidas relacionas às trocas gasosas e emissão de fluorescência da clorofila $a$ foram tomadas durante o processo de desenvolvimento das doenças.

\subsection{Material e Métodos}

Para a avaliação das alterações nos processos fisiológicos de folhas de feijoeiro durante o desenvolvimento das doenças foram realizados dois experimentos para ferrugem (F-i e F-ii), dois para mancha angular (M-i e M-ii) e dois para antracnose (A-i e A-ii). Os experimentos foram conduzidos em condição de ambiente controlado, testando a influência de diferentes temperaturas no desenvolvimento das doenças e nas mudanças provocadas pelos patógenos.

\subsubsection{Material vegetal e preparo das plantas}

Foram utilizadas duas cultivares de feijoeiro comum (Phaseolus vulgaris L.) com as seguintes características de resistência às doenças:

-Rosinha G-2: altamente suscetível a ferrugem, mancha angular e antracnose; -Carioca Comum: moderadamente suscetivel a ferrugem, mancha angular e antracnose. 
Sementes de feijoeiro das cultivares utilizadas foram pré-germinadas em placas de Petri por 48 horas no escuro ao redor de $25^{\circ} \mathrm{C}$. Em cada placa foram colocadas 10 sementes sobre duas folhas de papel de filtro embebidas em água destilada. Após a germinação, as plântulas foram transplantadas para vasos de alumínio com dois litros de mistura de terra argilosa, areia e esterco de curral, na proporção de $2: 2: 1$, e foram mantidas em condição de casa-de-vegetação até a inoculação. Em cada vaso foram transplantadas 4 plântulas e após 7 a 11 dias foi feito um desbaste deixando duas plantas por vaso. Todo este procedimento foi adotado para obter plantas bem homogêneas em relação à idade e tamanho de folhas.

\subsubsection{Obtenção e preparo de inóculo}

Urediniósporos do fungo Uromyces appendiculatus foram coletados de folhas com ferrugem no campo experimental do Setor de Fitopatologia, Departamento de Entomologia, Fitopatologia e Zoologia Agrícola da ESALQ/USP em Piracicaba/SP, e multiplicados em plantas da cv. Rosinha G-2 a $21{ }^{\circ} \mathrm{C}$ por inoculação dos folíolos com uma suspensão de urediniósporos em água+tween. Após a inoculação, as plantas foram cobertas com sacos plásticos para se formar uma câmara úmida e mantidas no escuro a $21{ }^{\circ} \mathrm{C}$ por 24 horas. Após este período, a câmara úmida foi retirada e as plantas incubadas em câmara de crescimento sob fotoperíodo de 12 horas. Os urediniósporos foram coletados logo após o início da esporulação das lesões de ferrugem e armazenados em cápsulas de gelatina colocadas em um frasco de vidro fechado contendo sílica gel sob condições de congelador $\left(-4^{\circ} \mathrm{C}\right)$.

O fungo Phaeoisariopsis griseola foi isolado de folhas de feijoeiro com mancha angular provenientes da região de Ponta Grossa/PR. Com auxílio de uma agulha foram transferidos conídios da face inferior das folhas para placas de Petri contendo meio ágarágua. As placas foram incubadas em estufas a $24{ }^{\circ} \mathrm{C}$ no escuro até que houvesse crescimento micelial e, a partir de então, o fungo isolado foi repicado para tubos de ensaio com meio de suco de tomate $(200 \mathrm{~mL}$ de suco de tomate integral $+15 \mathrm{~g}$ de ágar + 
4,5 g de $\mathrm{CaCO}_{3}+800 \mathrm{~mL}$ de água destilada) a $24{ }^{\circ} \mathrm{C}$ no escuro (Dalla Pria et al., 1997).

Quando iniciada a esporulação do fungo, após 10-14 dias da repicagem, foi adicionada água destilada esterilizada aos tubos, estes foram agitados e colocado $1 \mathrm{~mL}$ da suspensão resultante em placas de Petri contendo meio de suco de tomate. A suspensão foi espalhada por toda superficie do meio com auxílio de uma alça de Drigalski e depois a placa foi vedada com um filme plástico para evitar contaminação e manter a umidade. As placas foram mantidas nas mesmas condições anteriores e os conídios foram coletados, após 10 a 14 dias, no momento da inoculação, colocando água destilada sobre o meio e passando um pincel para a liberação dos conídios.

$\mathrm{O}$ isolado do fungo Colletotrichum lindemuthiamum, raça kappa, fornecido pela Estação Experimental do IAPAR, em Londrina, em meio de cultura BDA, foi repicado para tubos de ensaio contendo uma vagem de feijoeiro fixada em meio ágar-água a $2 \%$, autoclavados duas vezes, em condição de escuro a $24{ }^{\circ} \mathrm{C}$ para sua multiplicação (PioRibeiro \& Chaves, 1975). Para a inoculação, após duas a três semanas, quando ocorreu intensa esporulação do patógeno sobre a vagem, os conídios foram coletados colocando água destilada nos tubos e passando um pincel sobre a mucilagem produzida pelo fungo sobre a vagem.

Para as inoculações, foram feitas suspensões de esporos em água + tween 20 (uma gota por $100 \mathrm{~mL}$ ) com as concentrações ajustadas após contagem dos esporos em câmara de Neubauer.

\subsubsection{Inoculação e incubação}

Em todos experimentos, antes da inoculação das plantas, os vasos foram divididos em quatro grupos de quatro vasos com duas plantas cada um. Os dois primeiros grupos eram constituídos por plantas da cv. Rosinha G-2, sendo o primeiro com plantas sadias (RS) e o segundo com plantas doentes (RD). Da mesma forma, os dois últimos grupos eram constituídos por plantas da cv. Carioca Comum, sendo um com plantas sadias (CS) e o outro com plantas doentes (CD) 
As inoculações foram sempre realizadas nas duas faces das folhas das plantas dos grupos RD e CD por pulverização da suspensão de esporos até o início do escorrimento. Nos experimentos com ferrugem, aos 14 dias após o transplante (dat), quando a segunda folha trifoliolada tinha a maior largura do folíolo central entre 2 e 3 cm, a mesma foi inoculada com uma suspensão de $4,5 \times 10^{4}$ urediniósporos de $U$. appendiculatus por $\mathrm{mL}+$ espalhante no F-i e 5,5 x $10^{4}$ urediniósporos por $\mathrm{mL}$ no F-ii. No caso da mancha angular, aos 12 dat, quando a primeira folha trifoliolada tinha de 3,5$5,5 \mathrm{~cm}$ de maior largura no folíolo central, a mesma foi inoculada com uma suspensão de conídios de $P$. griseola + espalhante nas concentrações de $2,8 \times 10^{5}$ conídios por mL no M-i e $1,4 \times 10^{6}$ conídios por $\mathrm{mL}$ no $\mathrm{M}$-ii. Nos dois experimentos com antracnose (A-i e A-ii), a primeira folha trifoliolada foi inoculada com uma suspensão de $2,7 \times 10^{5}$ conídios de C. lindemuthianum por $\mathrm{mL}+$ espalhante quando, aos 14 dat, tinha a maior largura do folíolo central entre 3 e $5 \mathrm{~cm}$. Em todos os experimentos, a outra metade das plantas (RS e CS) recebeu somente a aplicação de água destilada + espalhante, permanecendo sadias.

Imediatamente após a inoculação, as plantas foram cobertas com um saco plástico umedecido e mantidas nesta condição de câmara úmida no escuro por 24 a 30 horas a $19^{\circ} \mathrm{C}$, no caso da ferrugem e antracnose, e a $24^{\circ} \mathrm{C}$, no caso da mancha angular. A temperatura neste período foi a mesma, independentemente da temperatura testada posteriormente, para que a infecção fosse a mesma em todas as plantas.

Após este período, os plásticos foram retirados e as plantas foram colocadas em câmaras de crescimento (Conviron E-7) sob diferentes temperaturas em regime

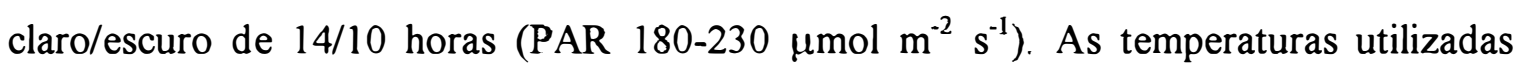
foram 15,19 e $23^{\circ} \mathrm{C}$, para ferrugem e antracnose, e 19,22 e $25^{\circ} \mathrm{C}$ para mancha angular.

Neste mesmo dia, para ferrugem, ou no dia seguinte, para antracnose e mancha angular, foi realizado o desponte e a desbrota das plantas retirando-se todas folhas acima da folha inoculada e todos brotos axilares para que não houvesse o sombreamento da folha a ser avaliada. As plantas foram adubadas após o desponte e a desbrota e após cinco dias com $100 \mathrm{~mL}$ de uma solução de nitrato de amônio na concentração de $0,35 \mathrm{~g}$ de $\mathrm{N}$ por litro de água. 


\subsubsection{Avaliação das trocas gasosas}

As avaliações dos processos fisiológicos taxa de respiração no escuro $(R e)$, taxa líquida de fotossintese com saturação da luz $(A)$, taxa de transpiração $(\operatorname{Tr})$ e condutância estomática $(g s)$ foram realizadas com o aparelho LI-6400 Portable Photosynthesis System $\left(\mathrm{Li}_{-\mathrm{Cor}}{ }^{\circledR}\right)$ no foliolo central das folhas inoculadas de plantas doentes e das folhas correspondentes das plantas sadias das duas cultivares. Apesar de terem duas plantas por vaso, apenas uma planta foi escolhida para as avaliações procurando obter a menor variabilidade entre as plantas avaliadas. Desta maneira, foram avaliadas 4 plantas por grupo ( $\mathrm{RS}, \mathrm{RD}, \mathrm{CS}$ e $\mathrm{CD}$ ) em cada tratamento (diferentes temperaturas).

Nos experimentos com ferrugem foram realizadas cinco avaliações, para cada temperatura, aos 5, 7, 9, 11 e 13 dias após a inoculação (dai). Para a mancha angular, também foram realizadas seis avaliações, para cada temperatura, aos 3, 5, 7, 9, 11 e 13 dai. No caso da antracnose, foram realizadas sete avaliações para cada temperatura, dos 2 aos 8 dai.

As condições durante as avaliações foram:

- Temperatura da folha dentro da câmara de análise: $25^{\circ} \mathrm{C}$;

-Intensidade da irradiação fornecida por uma fonte de luz 6400-02 LED light source (comprimento de onda entre 660 e $675 \mathrm{~nm}, \mathrm{PAR}$ ): $400 \mu \mathrm{mol} \mathrm{m}^{-2} \mathrm{~s}^{-1}$ (Apêndice 1);

-Fluxo de ar pela câmara de análise: $500 \mu \mathrm{mol} \mathrm{s}^{-1}$;

-Concentração de $\mathrm{CO}_{2}$ no ar entrando na câmara de análise: 360 a 380 ppm;

-Umidade relativa na câmara de análise: 30-50\%;

-Diferencial de pressão de vapor d'água na superficie foliar: 1,0-1,6;

-Razão estomática: 0,25 (Apêndice 2).

Para a avaliação da $A, \operatorname{Tr}$ e $g s$ o folíolo central da folha inoculada permaneceu na câmara de análise, em média, 5 minutos até a estabilização da leitura. Para a avaliação da $R e$ a fonte de luz foi desligada e a leitura feita após a estabilização da leitura ( 2 minutos em média). 
Após a primeira avaliação de cada folíolo, foi feita uma marca em torno da região que estava dentro da câmara de análise para que as próximas avaliações fossem feitas no mesmo local.

No final de cada avaliação, a região do folíolo central que estava dentro da câmara de análise $\left(6 \mathrm{~cm}^{2}\right)$ foi marcada com o auxílio de uma moldura e fotografada por uma câmara digital DC120 Zoom Digital Camera (Kodak DS ${ }^{\circledR}$ ) a $20 \mathrm{~cm}$ de distância, iluminada com 4 lâmpadas fluorescentes de $20 \mathrm{~W}$ (duas de cada lado). As imagens digitalizadas foram transferidas para um microcomputador e, posteriormente, foram processadas com o programa SIARCS 3.0. A análise das imagens foi feita da seguinte maneira: primeiramente a região a ser avaliada foi selecionada da imagem inicial (Figura $01 \mathrm{a})$, depois os pixels correspondentes às lesões foram selecionados pintando-os de uma só cor (Figura 01b). Em seguida a imagem foi binarizada, isto é, os pixels selecionados foram destacados em preto e o restante da imagem em branco, separando o objeto selecionado da cor do fundo (Figura 01c). Finalmente, foi feita a contagem dos pixels selecionados em preto (tecido doente) e dos pixels não selecionados em branco (tecido sadio) e determinada a proporção de tecido doente, isto é, a severidade de doença.

Nas folhas com ferrugem foi considerada na avaliação da severidade de doença a área ocupada pela pústula e pelo halo amarelado ao redor da pústula. Para mancha angular, foi considerado como tecido doente a área necrótica (cinza ou marrom) e a área amarelada ao seu redor, quando houvesse. No caso da antracnose, além da lesão vermelho-amarronzada nas nervuras, também foi considerado afetado e doente o tecido murcho e/ou seco ainda verde da folha infectada.

As variáveis relacionadas com as trocas gasosas foram relacionas entre si e com a severidade de doença por meio do coeficiente de Pearson ( $r$ ), sendo a relação significativa quando o nível de significância $(P)$ for menor que 0,05 . 


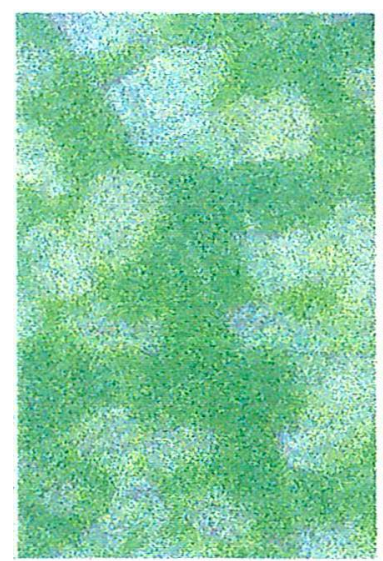

(a)

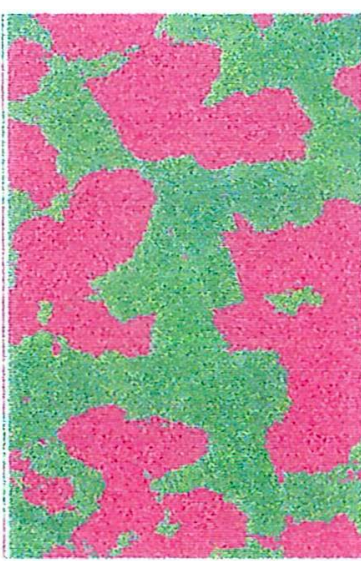

(b)

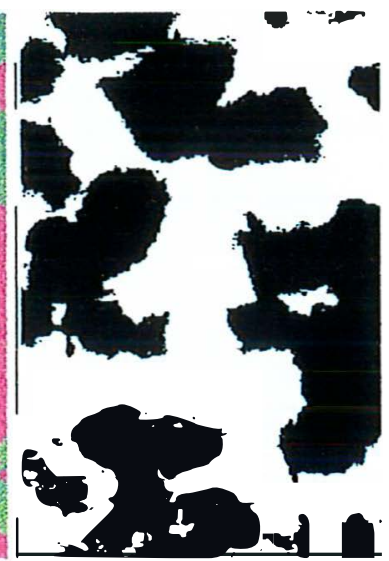

(c)

Figura 01. Etapas para a avaliação da severidade de doenças do feijoeiro por meio da análise de imagens em microcomputador pelo programa SIARCS 3.0: (a) seleção da área a ser avaliada; (b) seleção dos pixels correspondentes às lesões; (c) binarização.

\subsubsection{Avaliação das variáveis de fluorescência da clorofila $a$}

Os parâmetros $F_{0}$ (fluorescência mínima), $F_{\mathrm{m}}$ (fluorescência máxima) e $F_{\mathrm{v}} / F_{\mathrm{m}}$ (máxima eficiência quântica do fotossistema II) foram avaliados, com o fluorômetro PAM-2000, em regiões de folíolos sadios, regiões aparentemente sadias de folíolos doentes e em regiões sintomáticas de folíolos doentes das folhas inoculadas das duas cultivares nos experimentos $\mathrm{F}-\mathrm{i}$ com ferrugem e $\mathrm{M}-\mathrm{i}$ com mancha angular. No experimento A-ii com antracnose, foram avaliadas regiões de folíolos sadios, regiões aparentemente sadias de folíolos doentes, regiões apresentando necrose inicial das nervuras, regiões apresentando necrose adiantada das nervuras e início de murcha e regiões apresentando seca dos tecidos de folíolos da primeira folha trifoliolada das duas cultivares.

No experimento com ferrugem foram avaliadas 8 plantas por grupo em cada temperatura aos 4, 6, 8, 10 e 12 dai. Para mancha angular, foram avaliadas 4 plantas por 
grupo em cada temperatura aos 4,6, 8, 10, 12 e 13 dai. No caso da antracnose, foi realizada apenas uma avaliação aos 7 dai nas 4 plantas de cada grupo mantidas a $19{ }^{\circ} \mathrm{C}$.

Inicialmente, as regiões dos folíolos a serem avaliadas foram mantidas no escuro por 20 minutos com o uso de um clipe especial para este fim (Dark Leaf Clip DLC-8), que cobre uma área de aproximadamente $3,50 \mathrm{~cm}^{2}$ e permite o posicionamento da fibra óptica de leitura a $7 \mathrm{~mm}$ da superficie foliar, avaliando uma área de $0,385 \mathrm{~cm}^{2}$.

Em seguida, o valor de $F_{0}$ foi obtido pela emissão de uma luz com freqüência modulada de $600 \mathrm{~Hz}$ e intensidade 5. A seguir, com a emissão de um pulso de luz saturante de intensidade 8 por 0,6 segundos, obteve-se $F_{\mathrm{m}}$. Finalmente, o valor de $F_{\mathrm{v}} / F_{\mathrm{m}}$ era obtido pela eq. (1):

$$
F_{\mathrm{v}} / F_{\mathrm{m}}=\left(F_{\mathrm{m}}-F_{0}\right) / F_{\mathrm{m}}
$$

A severidade de doença na região avaliada $\left(0,385 \mathrm{~cm}^{2}\right)$ foi estimada através da contagem do número de lesões e da estimativa do tamanho médio destas lesões.

No experimento com mancha angular, foi realizado um segundo tipo de avaliação, na qual a influência de lesões individuais de diferentes tamanhos sobre as variáveis de fluorescência foi medida. Os valores de $F_{0}$ e $F_{\mathrm{m}}$ foram ajustados por regressão linear e, os valores de $F_{\mathrm{v}} / F_{\mathrm{m}}$, por regressão não-linear, em função da severidade de doença. 


\subsection{Resultados}

Para facilitar a interpretação e discussão dos resultados, os dados obtidos nos dois experimentos com cada doença foram analisados conjuntamente obtendo-se as médias dos valores de cada variável avaliada.

\subsubsection{Ferrugem}

\subsubsection{Progresso da doença}

Os principais estádios de desenvolvimento da ferrugem estão apresentados na Figura 02. As diferentes temperaturas atuaram de maneira distinta no progresso da doença (Tabela 01). A $23{ }^{\circ} \mathrm{C}$ a doença progrediu mais rapidamente e, a $15{ }^{\circ} \mathrm{C}$, mais lentamente, sendo o período de incubação maior e a velocidade de crescimento das lesões menor quanto menor a temperatura.

Não foram observadas diferenças entre as cultivares na velocidade de aparecimento dos sintomas e no crescimento das lesões, embora as pústulas de ferrugem produzidas na cv. Carioca Comum apresentassem um halo amarelo mais intenso e, na cv. Rosinha G-2, este halo amarelo fosse mais difuso. O início do aparecimento dos sintomas para as duas cultivares ocorreu entre 4 e 5 dai a 19 e $23{ }^{\circ} \mathrm{C}$ e entre 5 e 6 dai a $15{ }^{\circ} \mathrm{C}$. Com o aumento do tamanho das lesões (Tabela 01) a severidade aumentou a cada avaliação até a última aos 13 dai (Figuras 03a e 05a).

Com um número de lesões $/ \mathrm{cm}^{2}$ de folha ligeiramente maior na cv. Rosinha G-2, esta apresentou maiores severidades de doença (Figuras 03a e 05a). Aos 13 dai, as severidades de ferrugem na cv. Rosinha G-2 nas temperaturas de 23,19 e $15^{\circ} \mathrm{C}$ foram, respectivamente, ao redor de 60,48 e $42 \%$, enquanto que nas mesmas temperaturas na cv. Carioca Comum foram 50, 45 e $43 \%$. 
Tabela 01. Estádios de desenvolvimento da ferrugem e o diâmetro médio das lesões ( $\mathrm{mm}$ ) para cada temperatura em cada dia após a inoculação (dai) em que houve avaliação dos processos fisiológicos.

\begin{tabular}{|c|c|c|c|c|c|c|}
\hline \multirow[b]{2}{*}{ Dai } & \multicolumn{2}{|l|}{$15^{\circ} \mathrm{C}$} & \multicolumn{2}{|l|}{$19^{\circ} \mathrm{C}$} & \multicolumn{2}{|l|}{$23^{\circ} \mathrm{C}$} \\
\hline & Estádio & Diâm. & Estádio & Diâm. & Estádio & Diâm. \\
\hline 4 & sem sintomas aparentes & & $\begin{array}{l}\text { poucos pontos } \\
\text { encharcados }\end{array}$ & & pontos encharcados & \\
\hline 5 & $\begin{array}{l}\text { poucos pontos } \\
\text { encharcados }\end{array}$ & & $\begin{array}{l}\text { pontos encharcados e } \\
\text { poucos "flecks" }\end{array}$ & 0,65 & $\begin{array}{l}\text { pontos encharcados e } \\
\text { poucos "flecks" }\end{array}$ & 0,81 \\
\hline 6 & $\begin{array}{l}\text { pontos encharcados e } \\
\text { poucos "flecks" }\end{array}$ & 0,50 & $\begin{array}{c}\text { pontos encharcados e } \\
\text { "flecks" }\end{array}$ & 0,90 & "flecks" & 1,15 \\
\hline 7 & "flecks" & 0,67 & $100 \%$ de "flecks" & 1,20 & $\begin{array}{l}\text { "flecks" e primeiras } \\
\text { pústulas esporulando }\end{array}$ & 1,33 \\
\hline 8 & $100 \%$ de "flecks" & 0,75 & $\begin{array}{l}\text { "flecks" e primeiras } \\
\text { pústulas esporulando }\end{array}$ & 1,40 & $\begin{array}{l}100 \% \text { de pústulas } \\
\text { esporulando (início) }\end{array}$ & 1,70 \\
\hline 9 & inicio da esporulação & 1,10 & $\begin{array}{l}100 \% \text { de pústulas } \\
\text { esporulando (início) }\end{array}$ & 1,65 & $\begin{array}{l}100 \% \text { de pústulas } \\
\text { esporulando }\end{array}$ & 1,88 \\
\hline 10 & $\begin{array}{l}50 \% \text { de pústulas } \\
\text { esporulando }\end{array}$ & 1,20 & $\begin{array}{l}100 \% \text { de pústulas } \\
\text { esporulando }\end{array}$ & 1,72 & $\begin{array}{c}100 \% \text { de pústulas } \\
\text { esporulando (máxima) }\end{array}$ & 2,12 \\
\hline 11 & $\begin{array}{l}100 \% \text { de pústulas } \\
\text { esporulando }\end{array}$ & 1,55 & $\begin{array}{l}100 \% \text { de pústulas } \\
\text { esporulando (máxima) }\end{array}$ & 1,97 & $\begin{array}{l}100 \% \text { de pústulas } \\
\text { esporulando }\end{array}$ & 2,27 \\
\hline 12 & $\begin{array}{l}100 \% \text { de pústulas } \\
\text { esporulando }\end{array}$ & 1,77 & $\begin{array}{l}100 \% \text { de pústulas } \\
\text { esporulando }\end{array}$ & 2,12 & $\begin{array}{l}100 \% \text { de pústulas } \\
\text { esporulando }\end{array}$ & 2,37 \\
\hline 13 & $\begin{array}{l}100 \% \text { de pústulas } \\
\text { esporulando (máxima) }\end{array}$ & 1,92 & $\begin{array}{l}100 \% \text { de pústulas } \\
\text { esporulando }\end{array}$ & 2,28 & $\begin{array}{l}100 \% \text { de pústulas } \\
\text { esporulando }\end{array}$ & 2,49 \\
\hline
\end{tabular}

\subsubsection{Variáveis relacionadas com as trocas gasosas}

As Figuras 03-06 mostram claramente que o efeito da temperatura foi mais evidente no atraso do progresso da doença (Figuras 03a e 05a) e, conseqüentemente, as diferenças das variáveis relacionadas com as trocas gasosas entre folhas doentes e sadias se manifestaram mais rapidamente quanto maior a temperatura. Como a cv. Rosinha G-2 apresentou severidades ligeiramente maiores, as diferenças nas variáveis de troca gasosa foram também ligeiramente maiores que aqueles na cv. Carioca Comum. 

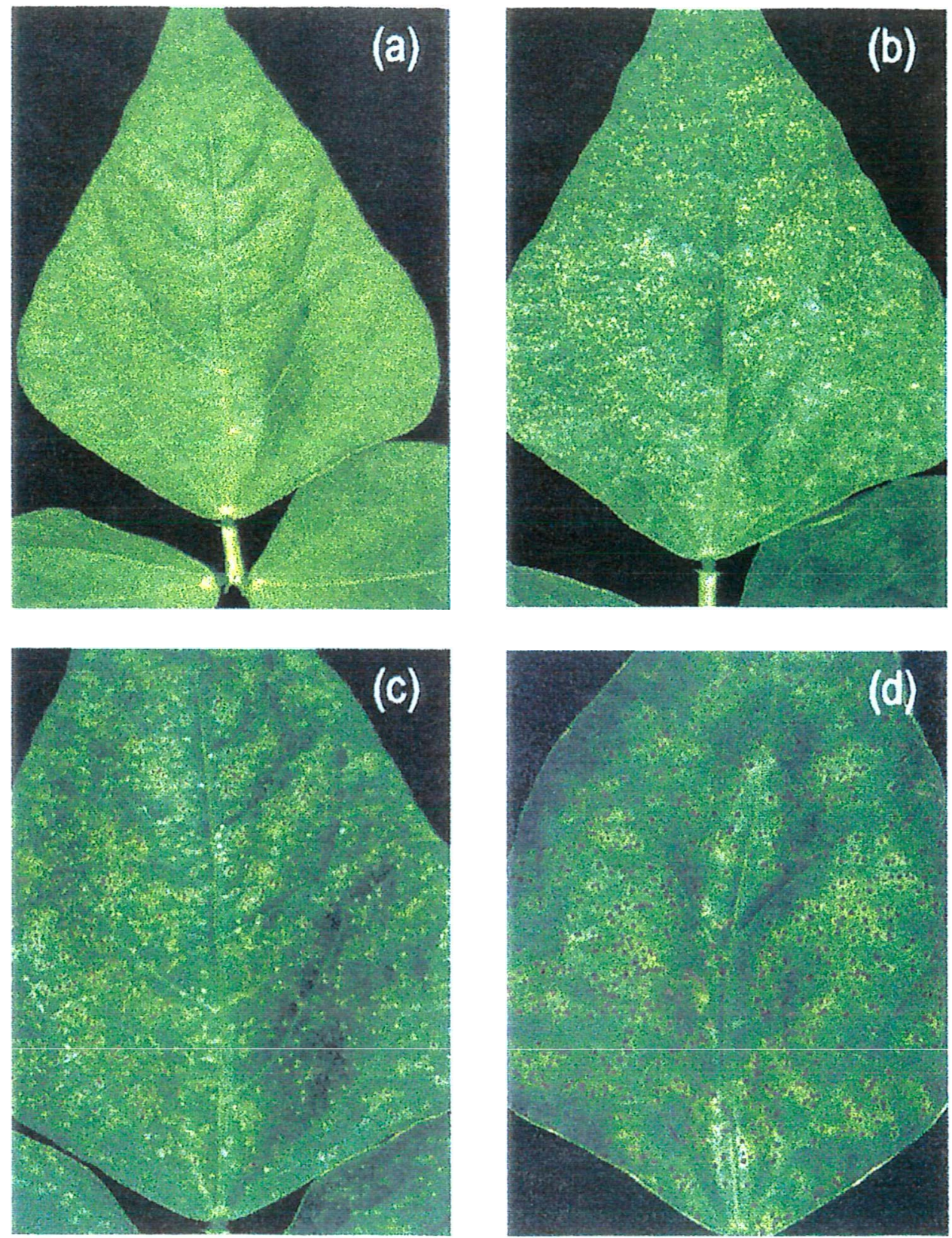

Figura 02. Estádios de desenvolvimento da ferrugem do feijoeiro: (a) pontuações pequenas e "encharcadas"; (b) "flecks"; (c) início da esporulação nas pústulas; (d) esporulação em $100 \%$ das pústulas. 

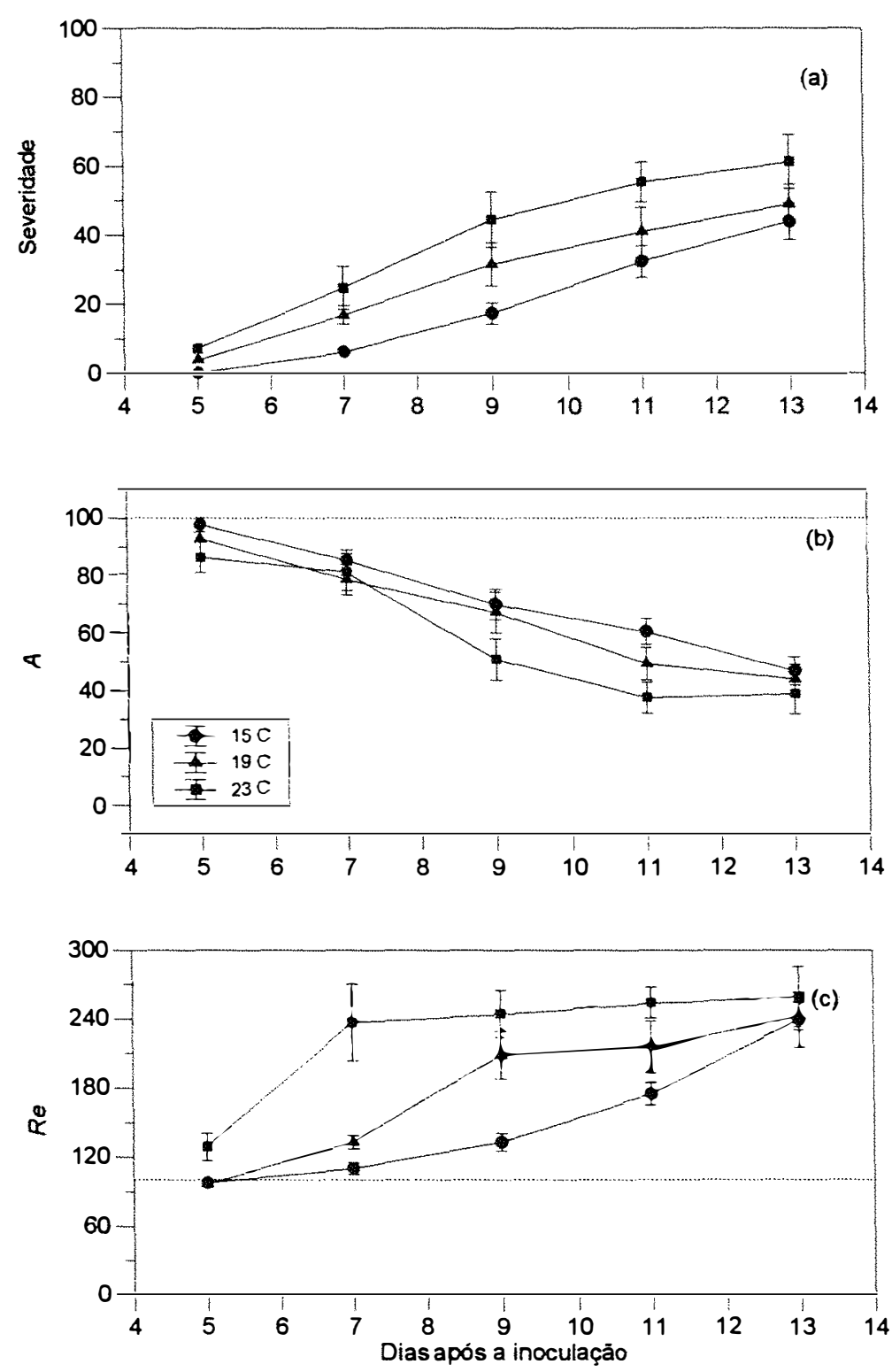

Figura 03. Valor médio (símbolo) e erro padrão (barra) da: (a) severidade de ferrugem (\%), (b) taxa de assimilação líquida de $\mathrm{CO}_{2}$ (\% do controle) e (c) taxa de respiração no escuro (\% do controle) de folhas doentes da cv. Rosinha G-2 crescidas em diferentes temperaturas após a inoculação. 

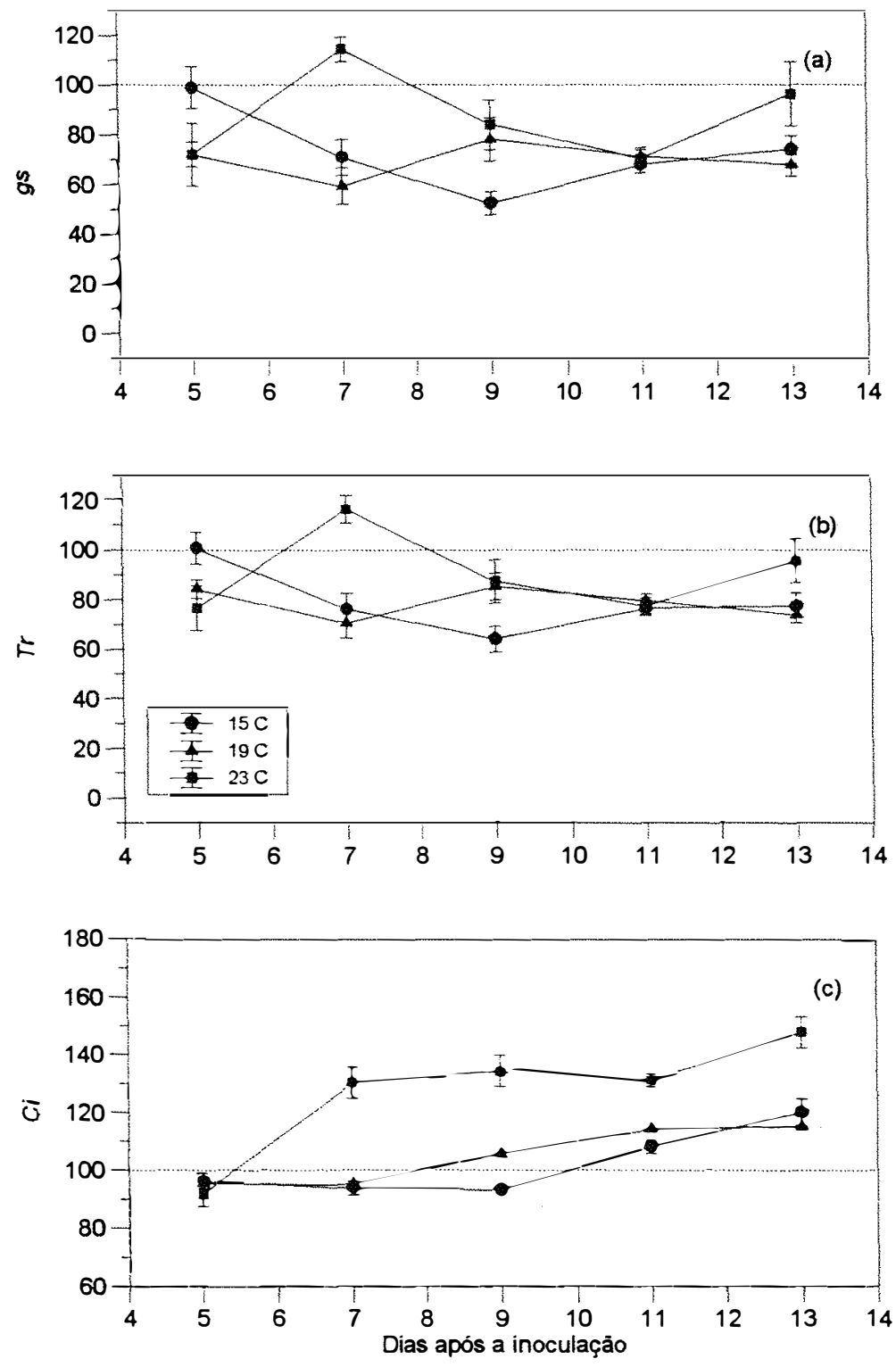

Figura 04. Valor médio (símbolo) e erro padrão (barra) da: (a) condutância estomática, (b) taxa de transpiração e (c) concentração intercelular de $\mathrm{CO}_{2}$ de folhas com ferrugem da cv. Rosinha G-2 crescidas em diferentes temperaturas após a inoculação (valores em \% do controle). 

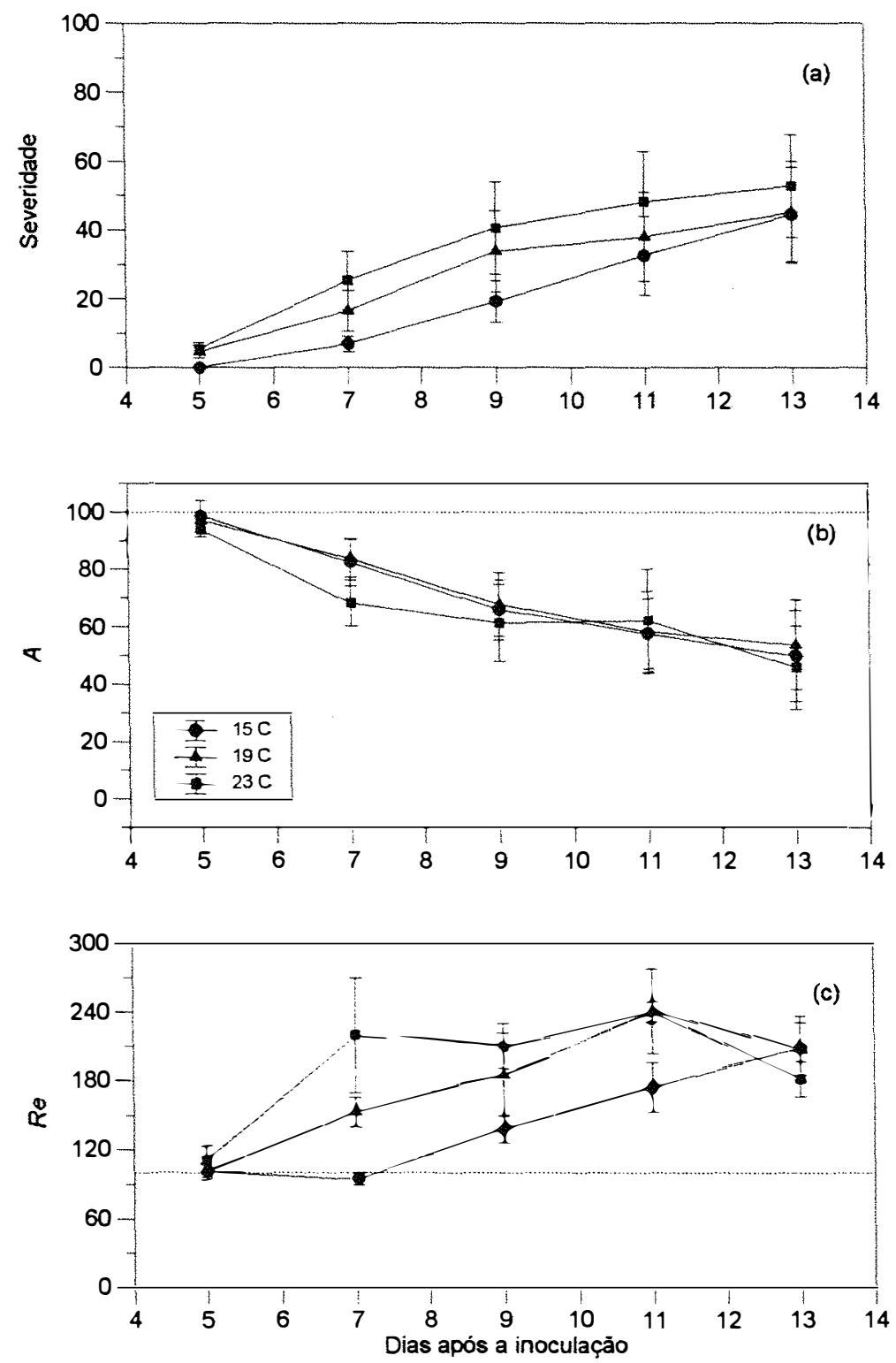

Figura 05. Valor médio (símbolo) e erro padrão (barra) da: (a) severidade de ferrugem (\%), (b) taxa de assimilação líquida de $\mathrm{CO}_{2}$ (\% do controle) e (c) taxa de respiração no escuro (\% do controle) de folhas doentes da cv. Carioca Comum crescidas em diferentes temperaturas após a inoculação. 

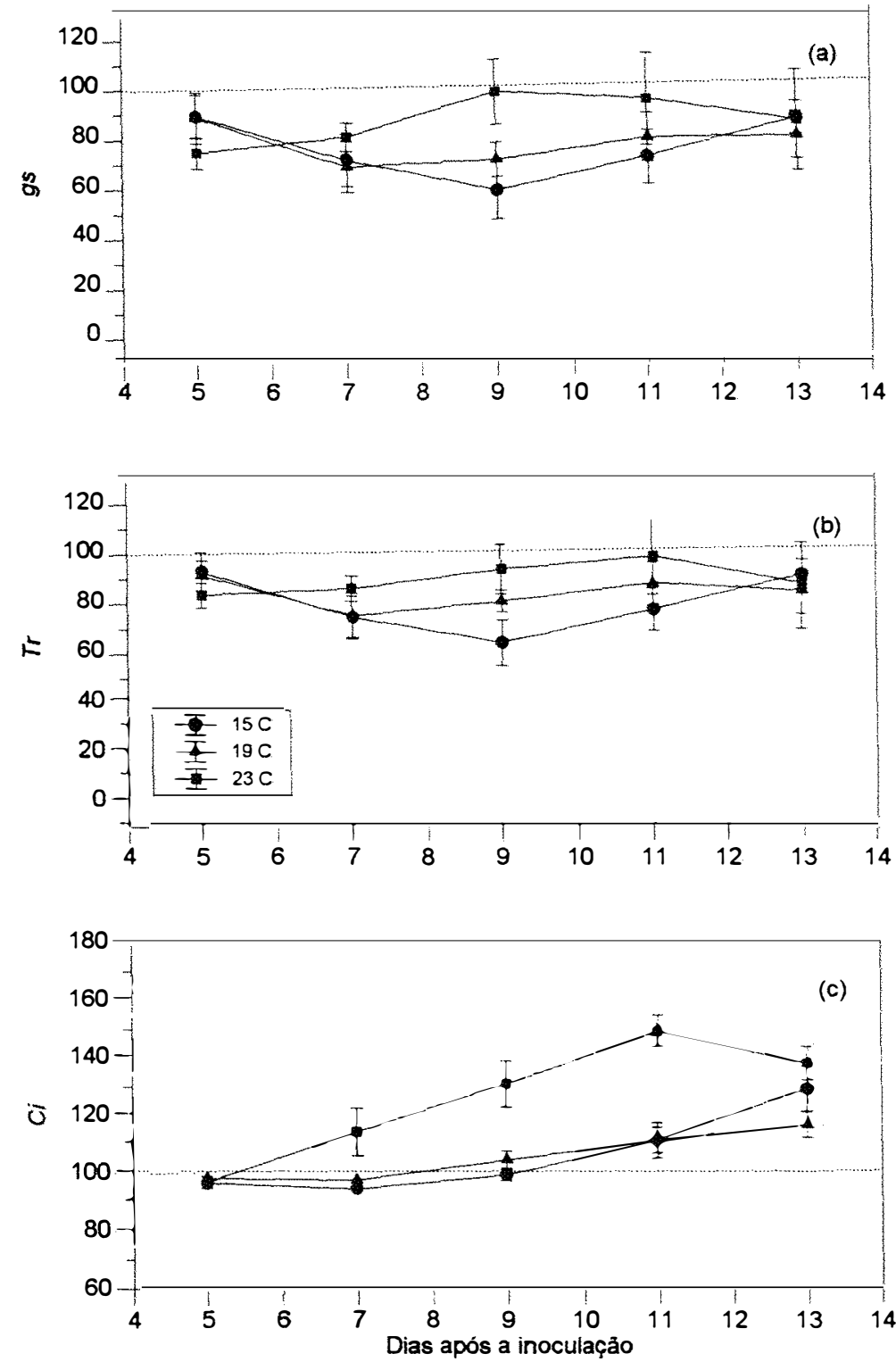

Figura 06. Valor médio (símbolo) e erro padrão (barra) da: (a) condutância estomática, (b) taxa de transpiração e (c) concentração intercelular de $\mathrm{CO}_{2}$ de folhas com ferrugem da cv. Carioca Comum crescidas em diferentes temperaturas após a inoculação (valores em \% do controle). 
Independentemente da temperatura e cultivar, foi observado que a $A$ das folhas doentes diminuiu em relação à taxa das folhas sadias à medida que a doença progrediu com o aumento da severidade $(r=-0,96 ; P=0,000)$, sendo primeiramente notada no estádio de aparecimento dos "flecks" (Figuras 03b e 05b). Esta redução foi ligeiramente maior que a redução da área foliar pela presença das pústulas. Aos 13 dai, as porcentagens de diminuição da $A$ das plantas doentes colocadas a 23,19 e $15^{\circ} \mathrm{C}$ na cv. Rosinha G-2 foram respectivamente em torno de 65,60 e 55, enquanto que para a cv. Carioca Comum foram em torno de 58, 50 e 54 .

Foi observado um aumento $R e$ nas folhas doentes em relação às folhas sadias a partir do aparecimento dos "flecks", sendo significativa a relação entre a $R e$ e a severidade de doença $(r=0,91 ; P=0,000)$. A $R e$ atingiu um valor máximo, em torno de 2 a 2,5 vezes maior que a $R e$ das plantas sadias, quando $100 \%$ das lesões estavam esporulando (Figuras $03 \mathrm{c}$ e $05 \mathrm{c}$ ). A partir dai se manteve neste nível ou decresceu à medida que a produção de esporos pela pústula diminuiu independentemente do aumento da severidade de doença.

As variáveis $g s$ (Figuras 04a e 06a) e $\operatorname{Tr}$ (Figuras 04b e 06b), não mostraram relação significativa com a severidade de doença $(P=0,472$ e 0,668 , respectivamente), não diminuindo nem aumentando com o aumento da severidade. Entretanto, as folhas doentes apresentaram quase sempre uma menor $g s$ e $\operatorname{Tr}$ em relação às folhas sadias. A $g s$ apresentou relação positiva com a $\operatorname{Tr}(r=0,97 ; P=0,000)$, mas não apresentou relação com a $A(P=0,689)$.

$\mathrm{A} C i$ das folhas doentes permaneceu próxima à $\mathrm{Ci}$ das folhas sadias (Figuras $04 \mathrm{c}$ e 06c) e, quando a severidade de doença atingiu entre 20 e $30 \%$, a $\mathrm{Ci}$ das folhas doentes começou a aumentar em relação às folhas sadias $(r=0,86 ; P=0,000)$. Apesar da relação entre a $g s$ e a $C i$ ser positiva $(r=0,54 ; P=0,002)$, foi observada uma relação negativa entre a $A$ e a $C i(r=-0,73 ; P=0,000)$ das folhas com ferrugem nas temperaturas e cultivares testadas. Também foi detectada nas folhas com ferrugem uma relação positiva entre a $\operatorname{Re}$ e a $C i(r=0,83 ; P=0,000)$ 


\subsubsection{Variáveis relacionadas com a emissão de fluorescência da clorofila $a$}

A mesma tendência apresentada anteriormente para as variáveis relacionadas com as trocas gasosas foi observada para as variáveis relacionadas à fluorescência da clorofila $a$, isto é, quanto maior a temperatura testada mais rápida foi a evolução da doença e mais rapidamente foram observadas as mudanças nas folhas doentes.

Apesar da área ocupada pelas pústulas de ferrugem atingirem entre 50 e $90 \%$ da área avaliada, poucas alterações foram notadas nas variáveis de fluorescência da clorofila $a$ (Figuras 07 e 08 ).

A $F_{0}$ praticamente não foi alterada durante as quatro primeiras avaliações nas regiões aparentemente sadias e regiões sintomáticas de folíolos doentes. Na última avaliação, aos 12 dai, quando $100 \%$ das pústulas estavam num estádio avançado de esporulação a 23 e $19{ }^{\circ} \mathrm{C}$, a $F_{0}$ teve um ligeiro aumento na cv. Rosinha G-2, mas diminuiu na cv. Carioca Comum.

A $F_{\mathrm{m}}$ das regiões aparentemente sadias de folíolos doentes praticamente não foi alterada em relação aos folíolos sadios. Entretanto, nas regiões sintomáticas de folíolos doentes a $F_{\mathrm{m}}$ foi reduzida à medida que a severidade de doença aumentava, ficando esta redução mais evidente a partir do aparecimento dos "flecks" e início da esporulação. A decréscimo da $F_{\mathrm{m}}$, porém, não acompanhou a mesma magnitude do aumento da severidade de ferrugem da área avaliada, ficando em torno de $20 \%$ enquanto a severidade estava entre 60 e $80 \%$.

A ausência de mudanças na $F_{0}$ e a pequena redução na $F_{\mathrm{m}}$ não foram suficientes para uma redução significativa nos valores de $F_{v} / F_{m}$ nas regiões com lesões, apesar de apresentar valores ligeiramente menores em relação aos folíolos sadios. Nas regiões aparentemente sadias de folíolos doentes não foram detectadas diferenças em relação ao controle. 
$23 \mathrm{C}$
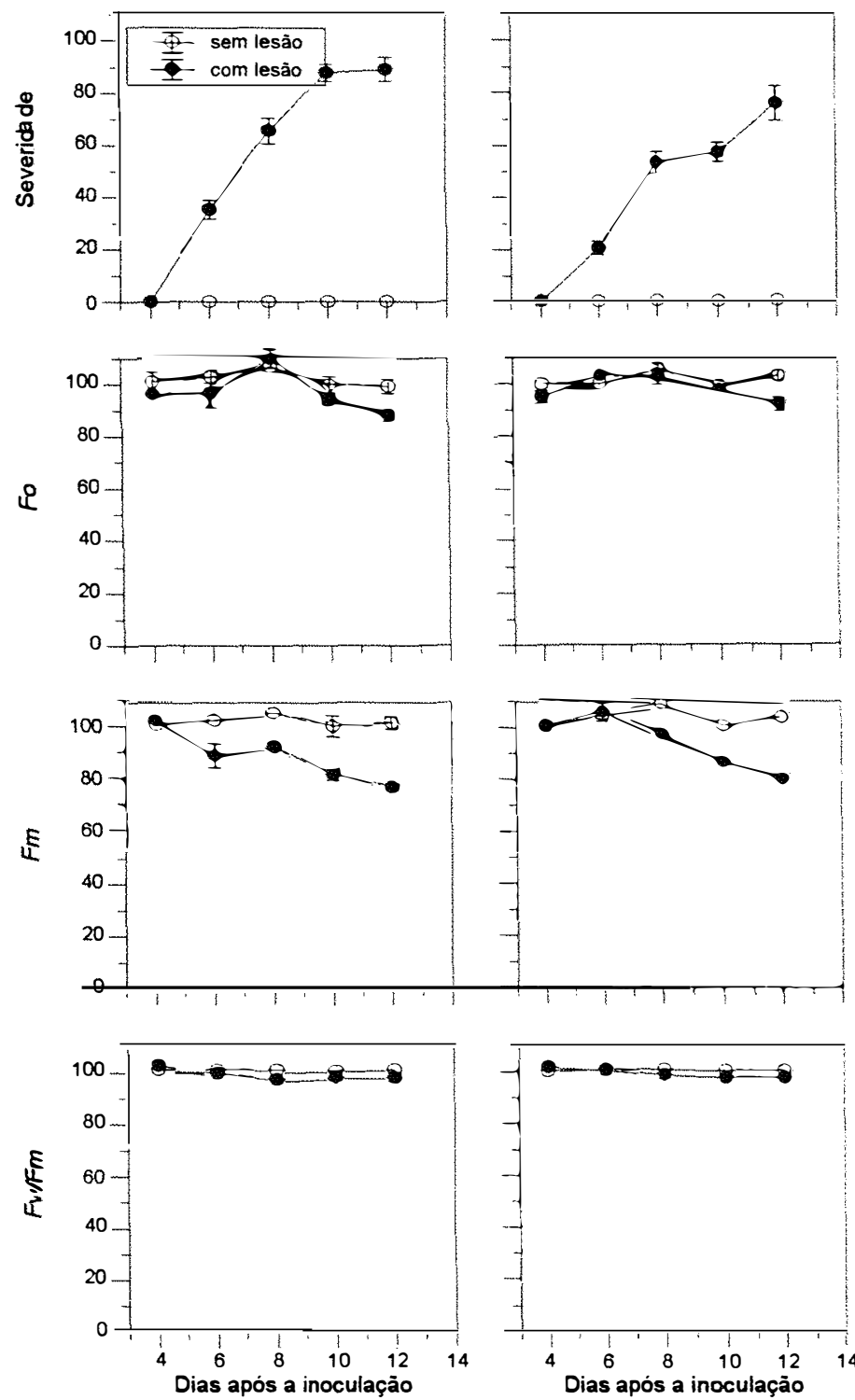

$19 \mathrm{C}$
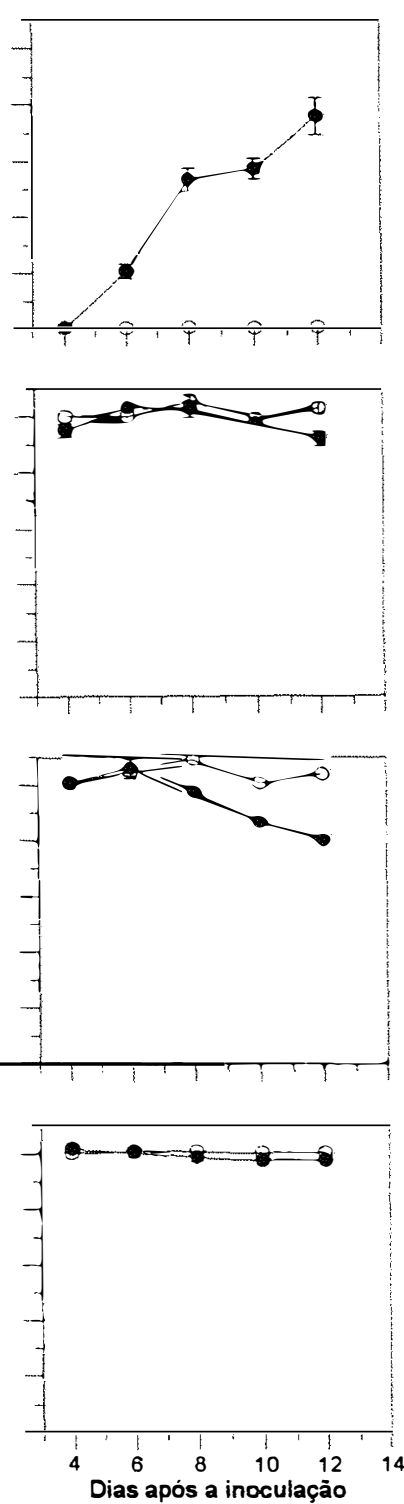

$15 \mathrm{C}$
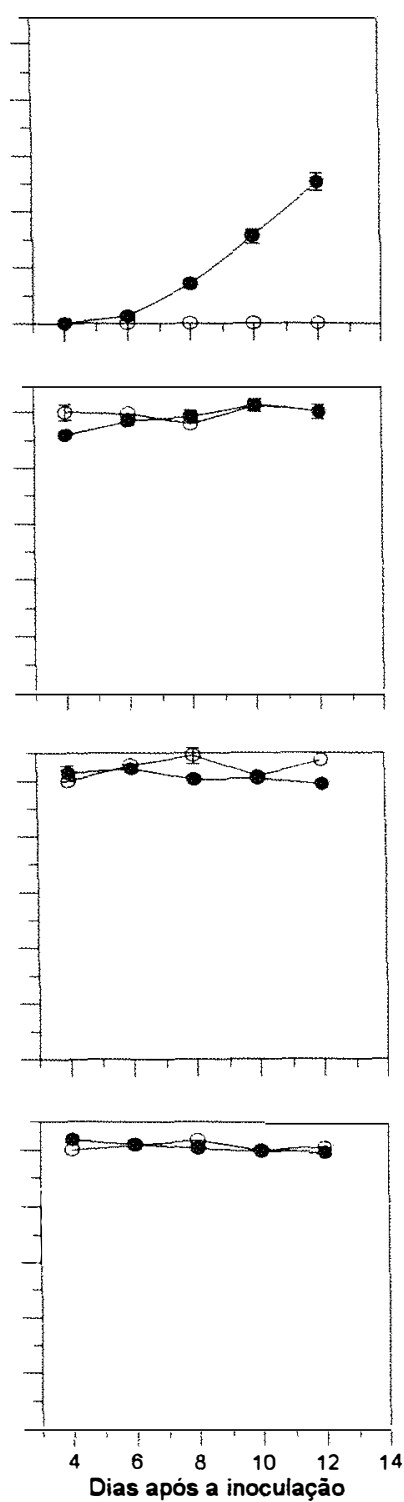

Figura 07. Valor médio (símbolo) e erro padrão (barra) da severidade de ferrugem (\%), fluorescência mínima $\left(F_{0}\right)$, fluorescência máxima $\left(F_{\mathrm{m}}\right)$ e máxima eficiência quântica do fotossistema II $\left(F_{\mathrm{v}} / F_{\mathrm{m}}\right)$ de regiões aparentemente sadias de folíolos doentes $(O)$ e regiões sintomáticas de folíolos doentes $(\bullet)$ da cv. Rosinha G-2 crescidos a 23,19 e $15^{\circ} \mathrm{C}$ após a inoculação (as variáveis de fluorescência estão apresentadas em \% do controle). 

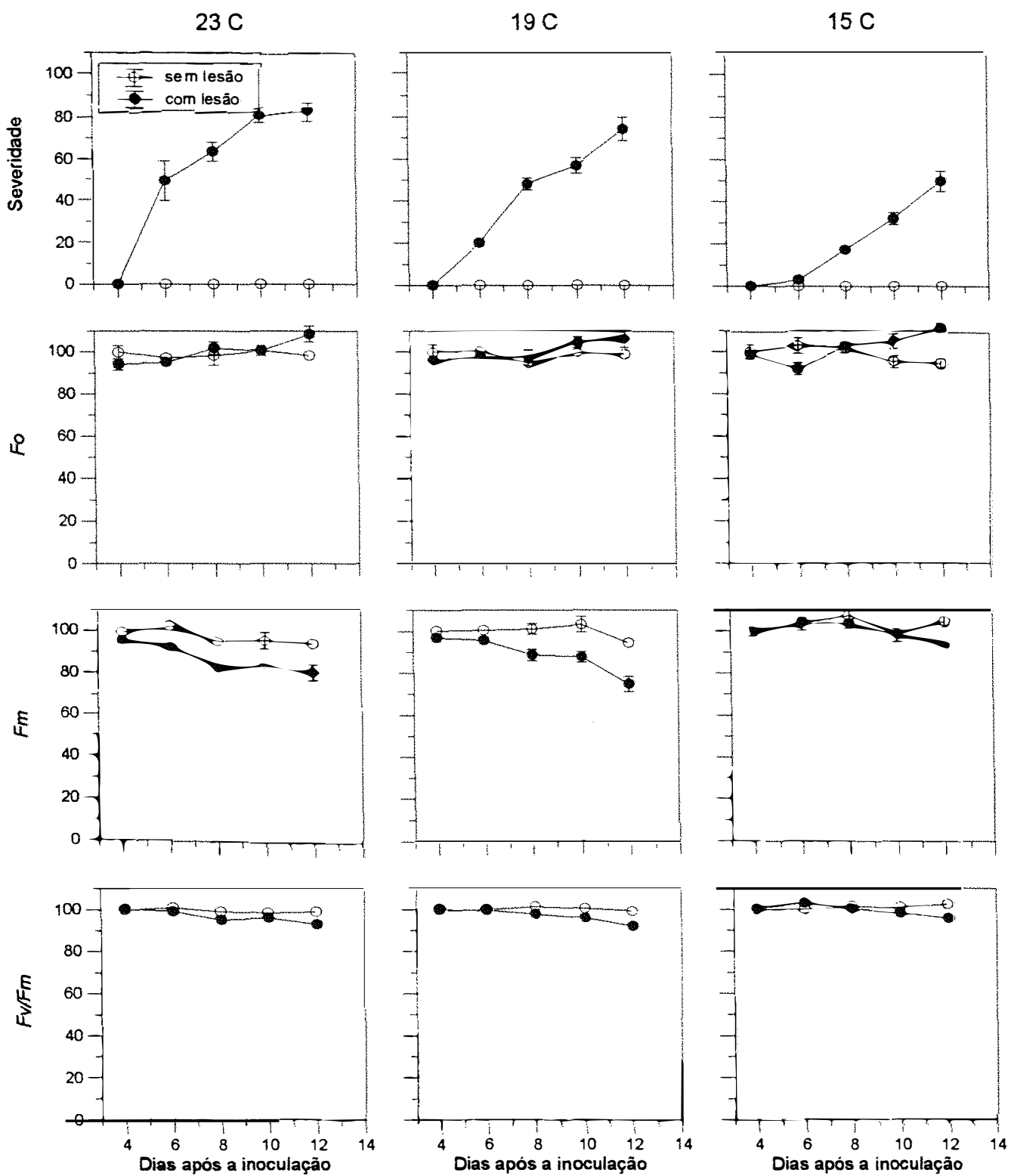

Figura 08. Valor médio (símbolo) e erro padrão (barra) da severidade de ferrugem (\%), fluorescência mínima $\left(F_{0}\right)$, fluorescência máxima $\left(F_{\mathrm{m}}\right)$ e máxima eficiência quântica do fotossistema II $\left(F_{\mathrm{v}} / F_{\mathrm{m}}\right)$ de regiões aparentemente sadias de folíolos doentes (O) e regiões sintomáticas de folíolos doentes $(\bullet)$ da cv. Carioca Comum crescidos a 23,19 e $15^{\circ} \mathrm{C}$ após a inoculação (as variáveis de fluorescência estão apresentadas em \% do controle) 


\subsubsection{Mancha angular}

\subsubsection{Progresso da doença}

Os estádios de desenvolvimento da doença e a variação no tamanho das lesões para cada temperatura em cada dia após a inoculação (dai) em que houve avaliação dos processos fisiológicos estão apresentados na Tabela 02. A Figura 09 ilustra alguns dos estádios de desenvolvimento da mancha angular em folhas de feijoeiro.

As diferentes temperaturas influenciaram o desenvolvimento da doença. A doença progrediu mais rapidamente a 25 que a $19{ }^{\circ} \mathrm{C}$, sendo o aparecimento dos sintomas mais lento e a velocidade de crescimento das lesões menor quanto menor a temperatura. Os primeiros sintomas foram observados aos 6 dai nas temperaturas de $22 \mathrm{e}$ $25^{\circ} \mathrm{C}$ e aos 7 dai a $19^{\circ} \mathrm{C}$ (Tabela 02). Contudo, devido à baixa umidade relativa presente na câmara de crescimento, entre 40 e $60 \%$, não foi observada a esporulação do fungo nas lesões formadas como freqüentemente ocorre em condições ambientes de campo.

Não foram observadas diferenças entre as cultivares na velocidade de aparecimento dos sintomas e no crescimento das lesões. Entretanto, foi observado que as manchas angulares necróticas na cv. Rosinha G-2 apresentavam um halo amarelo mais precocemente em relação à cv. Carioca Comum.

Quanto aos níveis de severidade obtidos em cada temperatura, estes foram maiores na cv. Rosinha G-2 que na cv. Carioca Comum (Figuras 10a e 12a). Aos 13 dai, a 25,22 e $19{ }^{\circ} \mathrm{C}$, as severidades médias na cv. Rosinha G-2 foram, ao redor de $91,95 \mathrm{e}$ $72 \%$, respectivamente, contra 85,65 e $50 \%$ na cv. Carioca Comum.

\subsubsection{Variáveis relacionadas com as trocas gasosas}

As Figuras 10 a 13 mostram que as diferenças entre as folhas doentes e sadias foram maiores quanto maior a severidade de doença obtida em cada temperatura testada. 
Tabela 02. Estádios de desenvolvimento da mancha angular e variação no tamanho das lesões $\left(\mathrm{mm}^{2}\right)$ para cada temperatura em cada dia após a inoculação (dai) em que houve avaliação dos processos fisiológicos.

\begin{tabular}{|c|c|c|c|c|c|c|}
\hline \multirow[b]{2}{*}{ Dai } & \multicolumn{2}{|l|}{$19^{\circ} \mathrm{C}$} & \multicolumn{2}{|l|}{$22^{\circ} \mathrm{C}$} & \multicolumn{2}{|l|}{$25^{\circ} \mathrm{C}$} \\
\hline & Estádio & Tam. & Estádio & Tam. & Estádio & Tam. \\
\hline 3 & sem sintomas aparentes & 0 & sem sintomas aparentes & 0 & sem sintomas aparentes & 0 \\
\hline 4 & sem sintomas aparentes & 0 & sem sintomas aparentes & 0 & sem sintomas aparentes & 0 \\
\hline 5 & sem sintomas aparentes & 0 & sem sintomas aparentes & 0 & sem sintomas aparentes & 0 \\
\hline 6 & sem sintomas aparentes & 0 & $\begin{array}{c}\text { inicio de pontuações } \\
\text { bem pequenas e } \\
\text { "encharcadas" }\end{array}$ & $<1$ & $\begin{array}{c}\text { inicio de pontuações } \\
\text { bem pequenas e } \\
\text { "encharcadas" }\end{array}$ & $<1$ \\
\hline 7 & $\begin{array}{c}\text { início de pontuações } \\
\text { bem pequenas e } \\
\text { "encharcadas" }\end{array}$ & $<1$ & $\begin{array}{c}\text { inicio de pequenas } \\
\text { áreas "encharcadas" e } \\
\text { necróticas }\end{array}$ & $1-2$ & $\begin{array}{l}\text { pequenas áreas } \\
\text { necróticas }\end{array}$ & $1-5$ \\
\hline 8 & $\begin{array}{c}\text { inicio de pequenas } \\
\text { áreas "encharcadas" e } \\
\text { necróticas }\end{array}$ & $<1$ & $\begin{array}{l}\text { pequenas áreas } \\
\text { necróticas }\end{array}$ & $1-2$ & $\begin{array}{c}\text { manchas angulares } \\
\text { necróticas }\end{array}$ & $2-4$ \\
\hline 9 & $\begin{array}{l}\text { pequenas áreas } \\
\text { necróticas }\end{array}$ & $1-4$ & $\begin{array}{c}\text { manchas angulares } \\
\text { necróticas }\end{array}$ & $2-6$ & $\begin{array}{c}\text { manchas angulares } \\
\text { necróticas }\end{array}$ & $3-9$ \\
\hline 10 & $\begin{array}{c}\text { manchas angulares } \\
\text { necróticas }\end{array}$ & $2-5$ & $\begin{array}{l}\text { manchas angulares } \\
\text { necróticas }\end{array}$ & $4-9$ & $\begin{array}{c}\text { manchas angulares } \\
\text { necróticas }\end{array}$ & $4-16$ \\
\hline 11 & $\begin{array}{c}\text { manchas angulares } \\
\text { necróticas }\end{array}$ & $3-6$ & $\begin{array}{c}\text { manchas angulares } \\
\text { necróticas }\end{array}$ & $4-9$ & $\begin{array}{l}\text { manchas angulares } \\
\text { necróticas e início de } \\
\text { amarelecimento }\end{array}$ & $6-16$ \\
\hline 12 & $\begin{array}{c}\text { manchas angulares } \\
\text { necróticas }\end{array}$ & $6-9$ & $\begin{array}{c}\text { manchas angulares } \\
\text { necróticas }\end{array}$ & $5-16$ & $\begin{array}{c}\text { manchas angulares } \\
\text { necróticas e } \\
\text { amarelecimento }\end{array}$ & $9-20$ \\
\hline 13 & $\begin{array}{c}\text { manchas angulares } \\
\text { necróticas }\end{array}$ & $9-18$ & $\begin{array}{l}\text { manchas angulares } \\
\text { necróticas e inicio de } \\
\text { amarelecimento }\end{array}$ & $9-20$ & $\begin{array}{c}\text { manchas angulares } \\
\text { necróticas, } \\
\text { amarelecimento e seca }\end{array}$ & $11-25$ \\
\hline
\end{tabular}



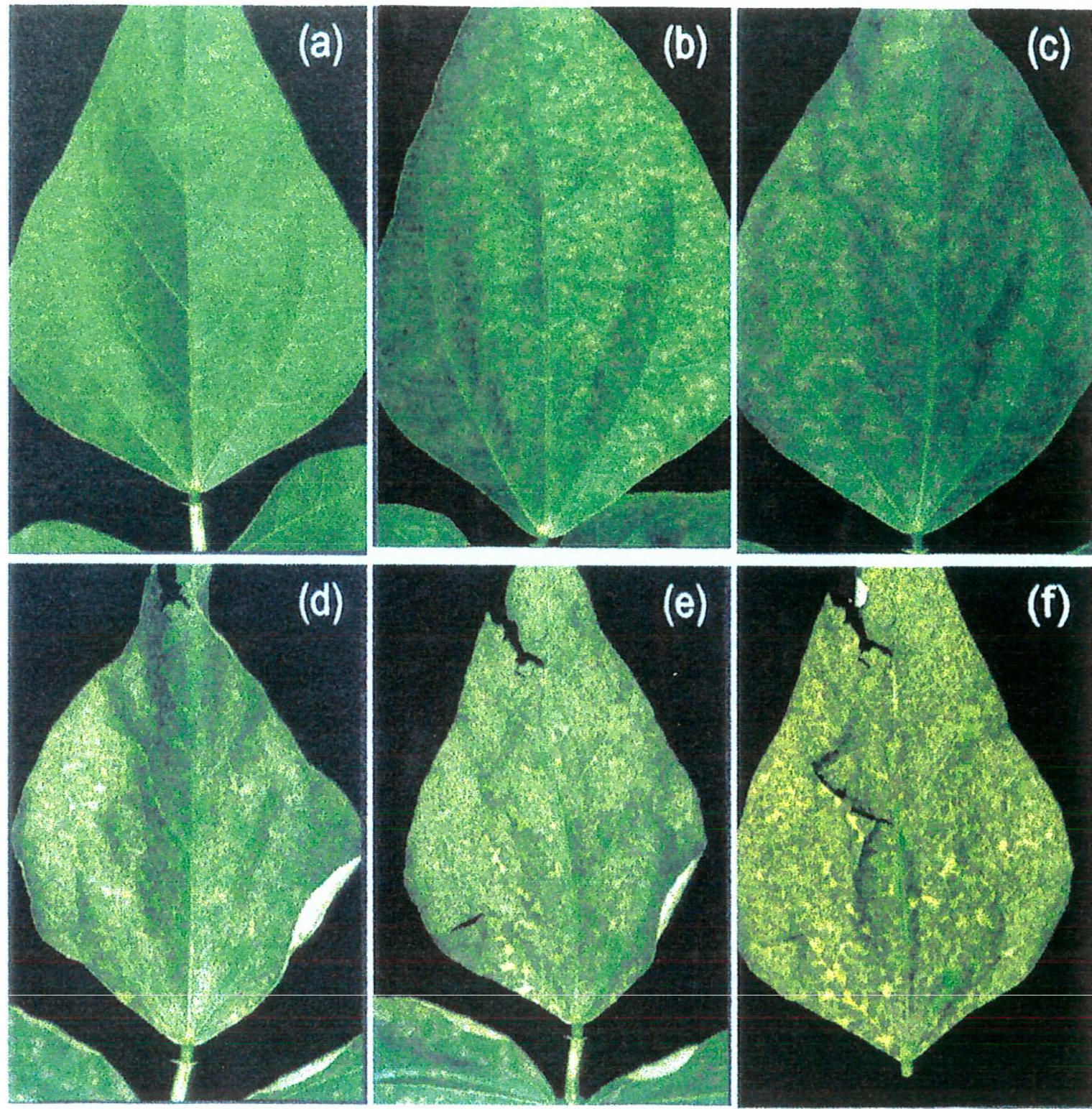

Figura 09. Estádios de desenvolvimento da mancha angular do feijoeiro: (a) pontuações pequenas e "encharcadas"; (b) pequenas manchas necróticas; (c) manchas angulares necróticas; (d) manchas angulares necróticas e início do amarelecimento entre as manchas; (e) manchas angulares necróticas e amarelecimento entre as manchas; (f) amarelecimento e seca da folha. 

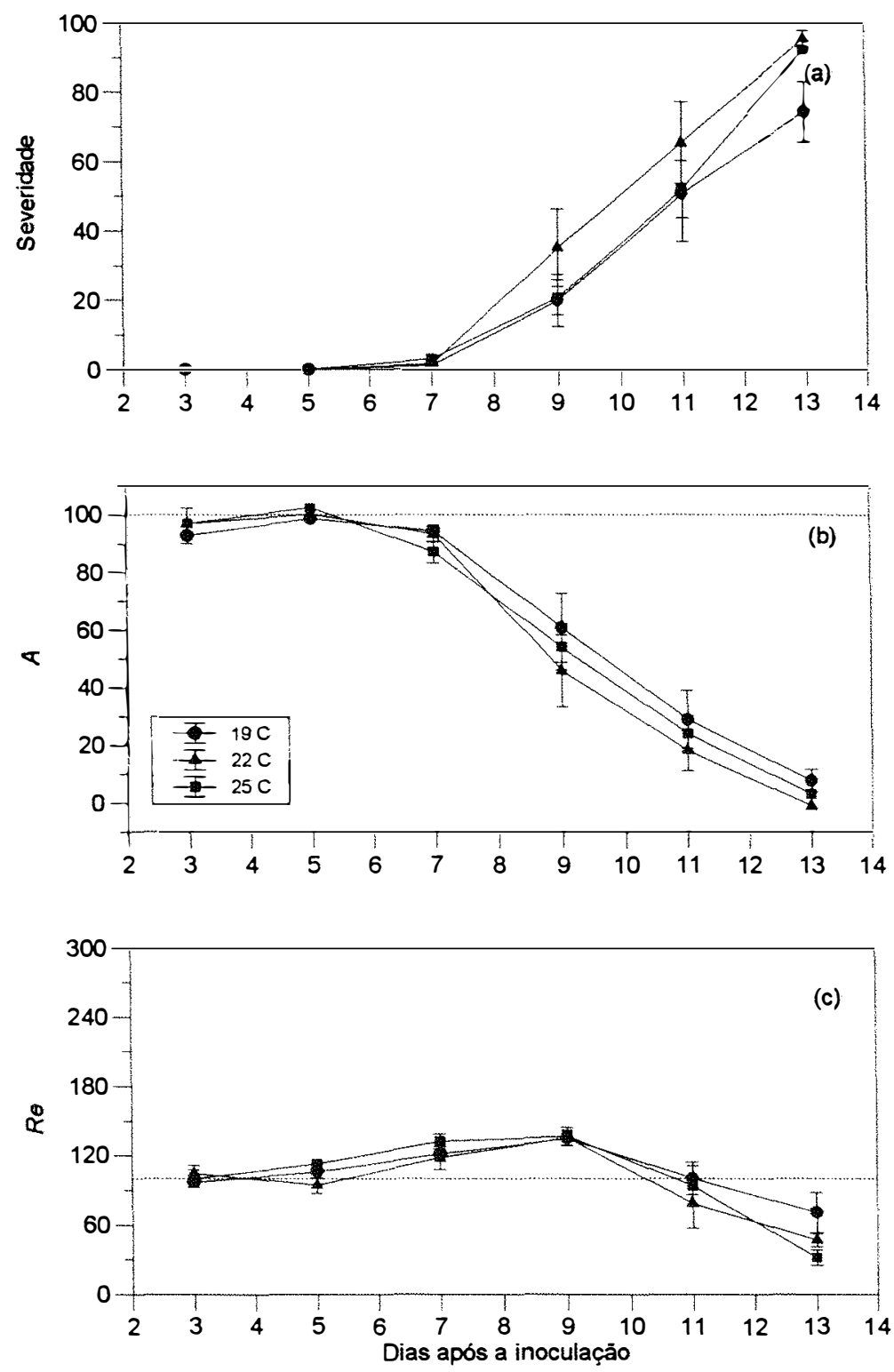

Figura 10. Valor médio (símbolo) e erro padrão (barra) da: (a) severidade de mancha angular (\%), (b) taxa de assimilação líquida de $\mathrm{CO}_{2}$ (\% do controle) e (c) taxa de respiração no escuro (\% do controle) de folhas doentes da cv. Rosinha G-2 crescidas em diferentes temperaturas após a inoculação. 

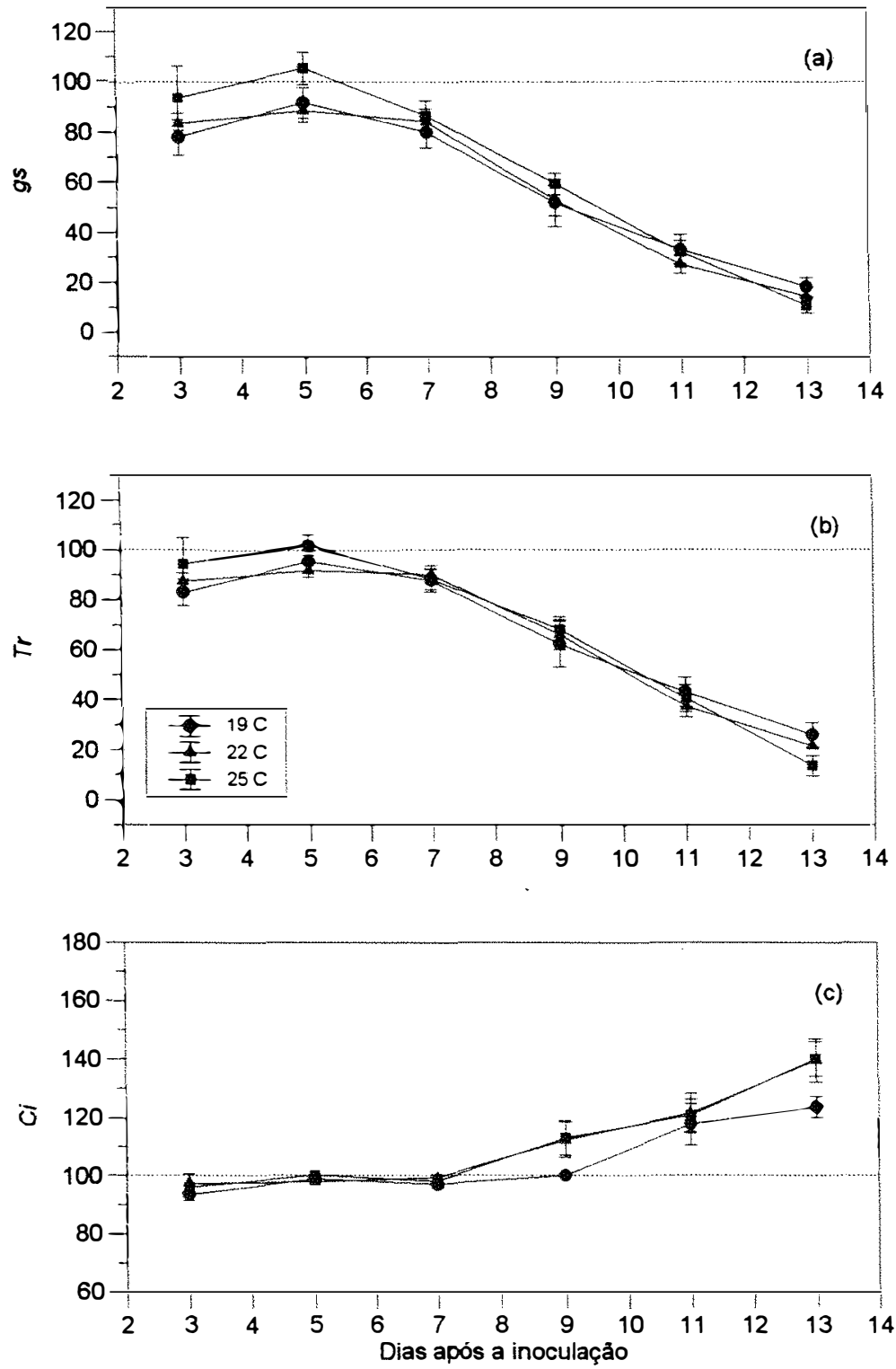

Figura 11. Valor médio (símbolo) e erro padrão (barra) da: (a) condutância estomática, (b) taxa de transpiração e (c) concentração intercelular de $\mathrm{CO}_{2}$ de folhas com mancha angular da cv. Rosinha G-2 crescidas em diferentes temperaturas após a inoculação (valores em \% do controle). 

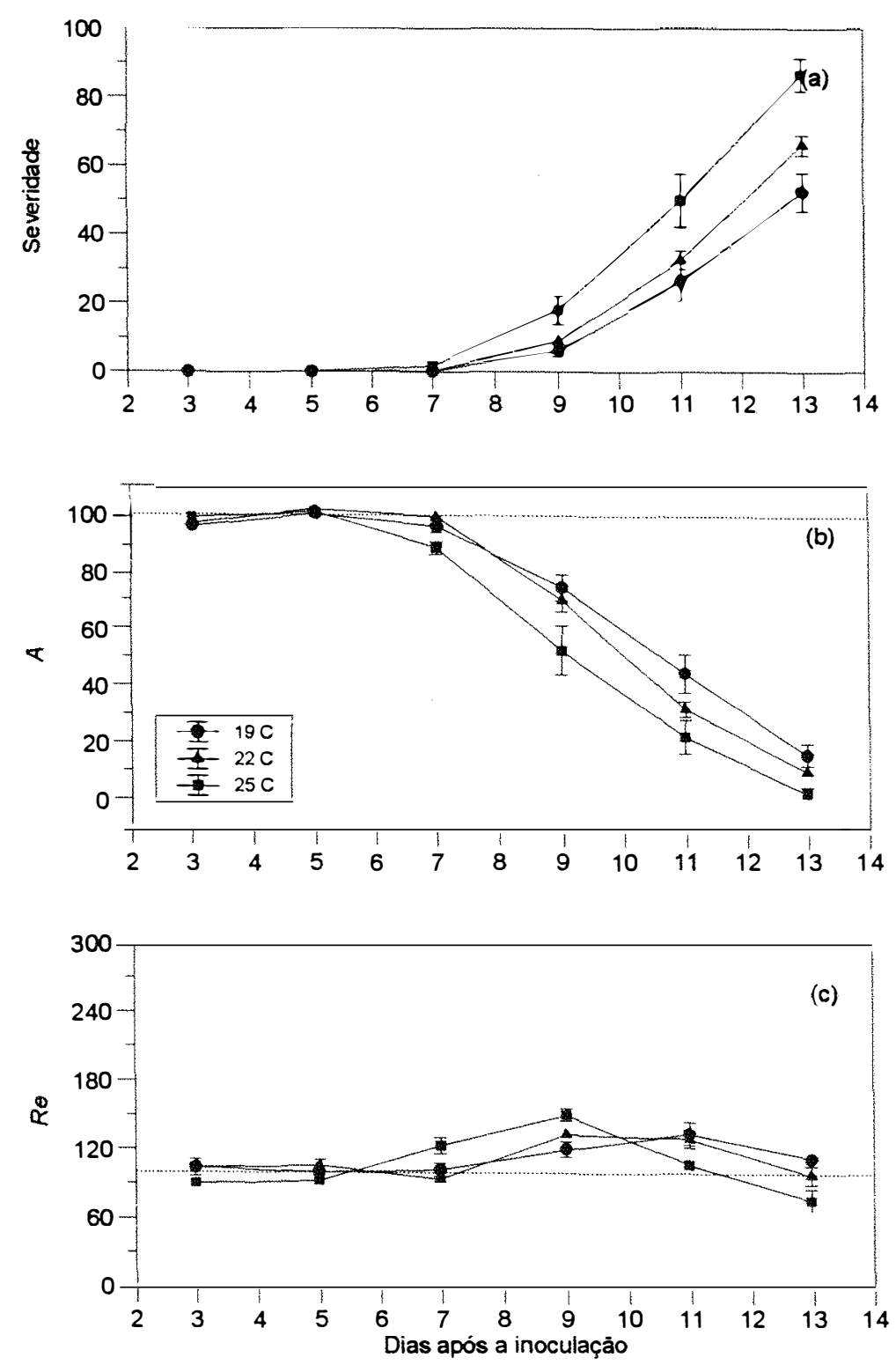

Figura 12. Valor médio (símbolo) e erro padrão (barra) da: (a) severidade de mancha angular (\%), (b) taxa de assimilação líquida de $\mathrm{CO}_{2}$ (\% do controle) e (c) taxa de respiração no escuro (\% do controle) de folhas doentes da cv. Carioca Comum crescidas em diferentes temperaturas após a inoculação. 

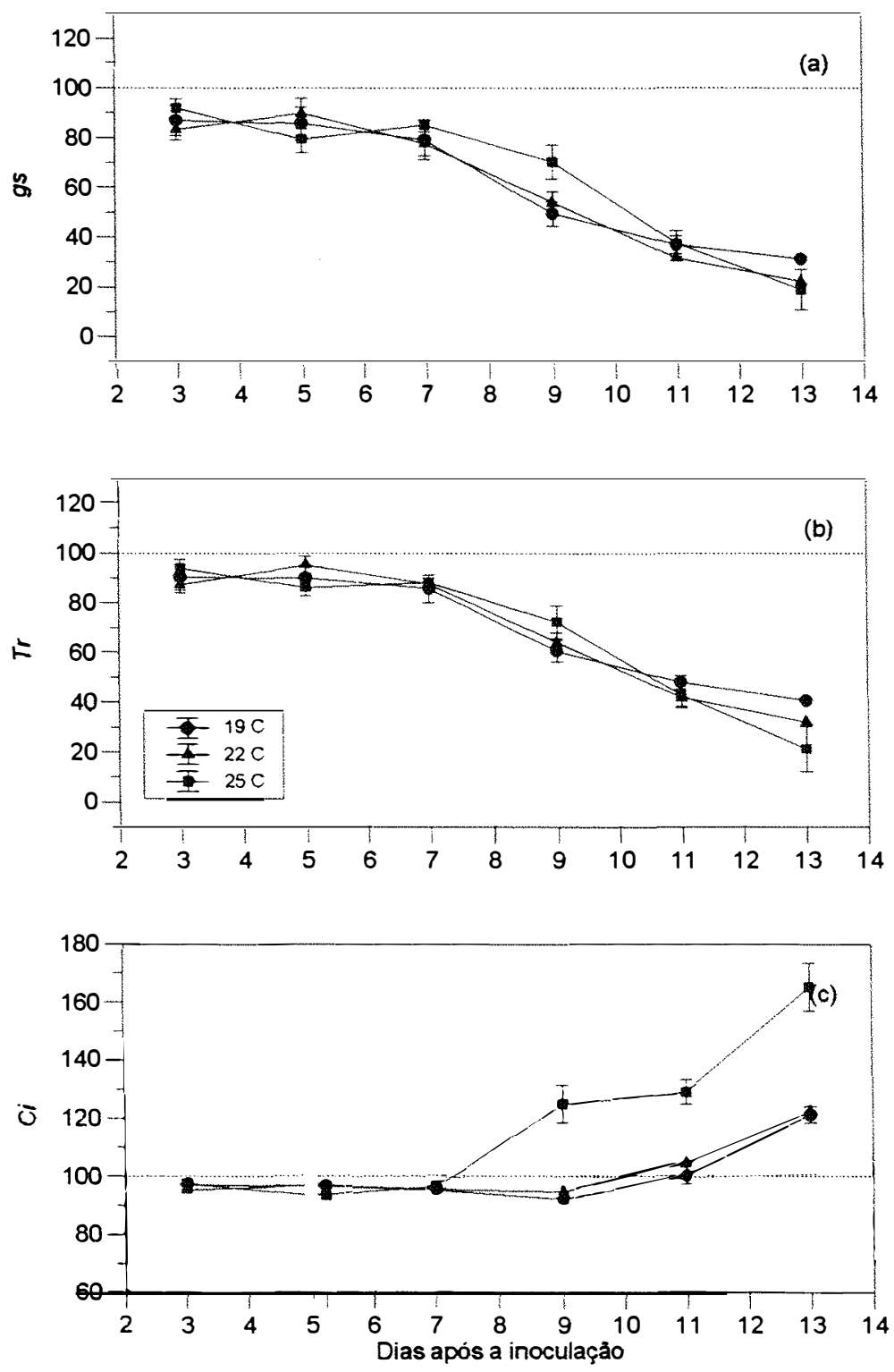

Figura 13. Valor médio (símbolo) e erro padrão (barra) da: (a) condutância estomática, (b) taxa de transpiração e (c) concentração intercelular de $\mathrm{CO}_{2}$ de folhas com mancha angular da cv. Carioca Comum crescidas em diferentes temperaturas após a inoculação (valores em \% do controle). 
Independentemente da temperatura e da cultivar, foi observado um decréscimo da $A$ das folhas doentes em relação à taxa das folhas sadias que se acentuou à medida que a doença progrediu com $o$ aumento da severidade $(r=-0,96 ; P=0,000)$. Este decréscimo tornou-se aparente com o aparecimento dos primeiros sintomas (início de pequenas áreas "encharcadas" e necróticas) a partir dos 5-7 dai a 22 e $25{ }^{\circ} \mathrm{C}$ e dos 6-9 dai a $19^{\circ} \mathrm{C}$ (Figuras $10 \mathrm{~b}$ e $12 \mathrm{~b}$ ). Geralmente, a redução na $A$ das folhas doentes foi maior que a ocupação da área foliar verde pelas lesões angulares necróticas. Aos 13 dai, as reduções da $A$ das plantas doentes colocadas a 23,19 e $15^{\circ} \mathrm{C}$ na cv. Rosinha G-2 foram da ordem de 98,100 e $92 \%$, respectivamente, enquanto que para a cv. Carioca Comum foram da ordem de 97,90 e $82 \%$.

A $R e$ das folhas inoculadas com $P$. griseola manteve-se semelhante à $R e$ das folhas sadias até o aparecimento dos primeiros sintomas. A partir daí, a $R e$ das folhas infectadas aumentou em relação à das folhas sadias, atingindo um valor máximo em torno de 1,5 vez maior que a $R e$ das folhas sadias quando as lesões necróticas apresentaram 3-9 $\mathrm{mm}^{2}$ de tamanho. Houve um decréscimo na $R e$ a partir do início da senescência precoce da folha causada para ação do patógeno (Figuras $10 \mathrm{c}$ e $12 \mathrm{c}$ ). O decréscimo da $R e$ das folhas doentes foi iniciado quando a severidade de doença passou dos $20 \%$ e no caso da cv. Rosinha G-2, nas duas últimas avaliações foram observados valores abaixo da $R e$ das folhas sadias (Figura 10c). Na cv. Rosinha G-2, o aumento e decréscimo da Re das folhas doentes foram observados geralmente em torno de um dia antes das as mudanças na cv. Carioca Comum.

Comportamentos semelhantes foram observados para as variáveis $g s$ e $\operatorname{Tr}$ nas folhas com mancha angular $(r=0,99 ; P=0,000)$. Notou-se que ambas, $g s$ (Figuras 11 a e 13a) e $\operatorname{Tr}$ (Figuras $11 \mathrm{~b}$ e $13 \mathrm{~b}$ ), diminuem mais intensamente com o progresso da doença e aumento da severidade a partir do início dos sintomas $(r=-0,75 ; P=0,000$, para $g s \mathrm{x}$ severidade, e $r=-0,95 ; P=0,000$, para $\operatorname{Tr} \mathrm{x}$ severidade). Houve relação positiva entre a gs e a $A(r=0,96 ; P=0,000)$ porém, entre as temperaturas, a redução da $g s$ e a redução observada na $A$ não foram da mesma magnitude, por exemplo: as folhas a $25^{\circ} \mathrm{C}$ na cv. Carioca Comum (Figuras 12a e 12b) tiveram maiores severidades e menores $A$ em 
relação às outras temperaturas, mas praticamente não houve diferença entre as temperaturas nas variáveis gs e $\operatorname{Tr}$ (Figuras 13a e 13b).

Como observado nas Figuras 11c e 13c, a $C i$ das folhas doentes permaneceu próxima aos valores da $\mathrm{Ci}$ das folhas sadias, mas quando a severidade de doença passou dos $20 \%$, a $C i$ das folhas doentes começou a aumentar em relação à das folhas não inoculadas $(r=0,91 ; P=0,000)$. A relação negativa entre a $A$ e a $C i$, observada para as folhas com ferrugem, nas temperaturas e cultivares testadas, foi também observada para a mancha angular $(r=-0,86 ; P=0,000)$. Enquanto a $A$ diminuiu a partir dos 7 dai, 0 aumento da $C i$ só foi observado uma avaliação mais tarde. Quanto à relação $C i$ e $g s$, a $C i$ pareceu acompanhar a mesma tendência da gs até o momento em que a $C i$ passou a aumentar mesmo com a diminuição da $g s(r=-0,77 ; P=0,000)$. A $C i$ teve uma fraca relação com a $R e$ das folhas doentes, permanecendo constante enquanto a $R e$ aumentava e aumentando enquanto a $\operatorname{Re}$ diminuía $(r=-0,47 ; P=0,000)$.

\subsubsection{Variáveis relacionadas com a emissão de fluorescência da clorofila $a$}

Quanto às variáveis relacionadas à fluorescência da clorofila $a$, a mesma tendência apresentada anteriormente foi observada, isto é, quanto mais favorável a temperatura testada mais rápida foi a evolução da doença e mais rapidamente foram observadas as mudanças nas folhas doentes. Neste caso, independentemente da cultivar, a temperatura mais favorável foi de $25^{\circ} \mathrm{C}$ adiantando a doença ao redor de um dia em relação a $22{ }^{\circ} \mathrm{C}$ e dois dias em relação a $19{ }^{\circ} \mathrm{C}$.

As variáveis $F_{0}$ e $F_{\mathrm{v}} / F_{\mathrm{m}}$ nas regiões com lesões praticamente não foram alteradas até que os sintomas de manchas angulares necróticas estivessem bem definidos aos 10 a 11 dai (Figuras 14 e 15). A partir deste momento, as duas variáveis diminuíram bastante, acompanhando o aumento da severidade da doença. Quanto à variável $F_{\mathrm{m}}$, foi observada uma redução já no início do aparecimento dos sintomas, aumentando a redução em relação às folhas sadias à medida que a doença evoluiu. 
$25 \mathrm{C}$
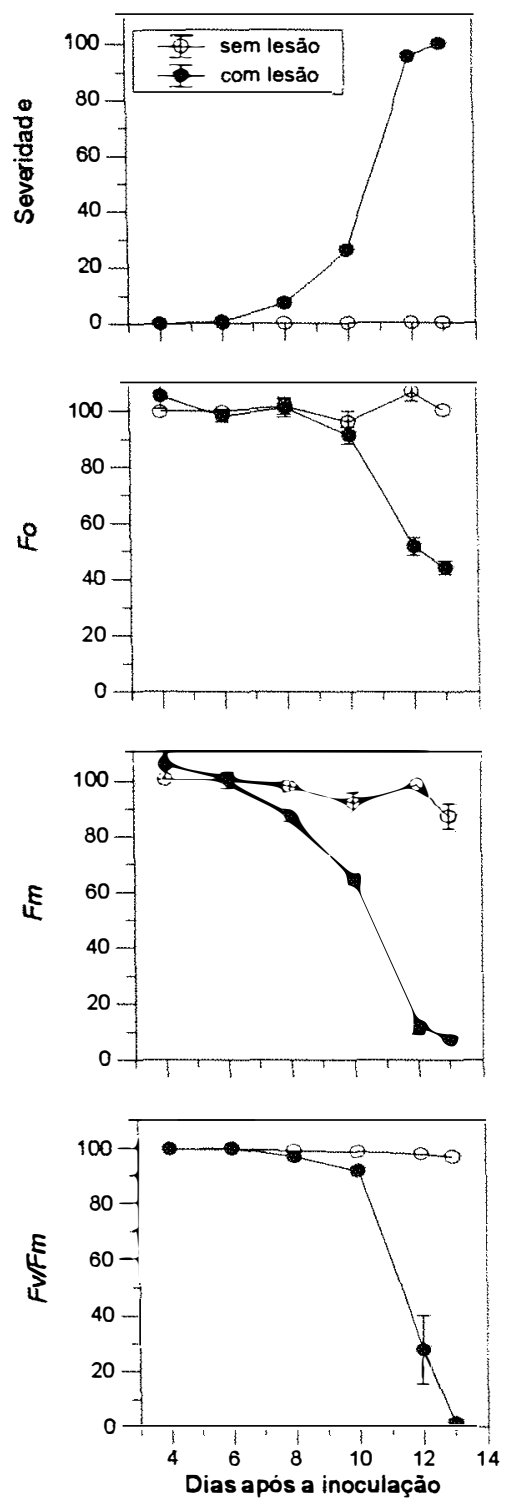

$22 \mathrm{C}$
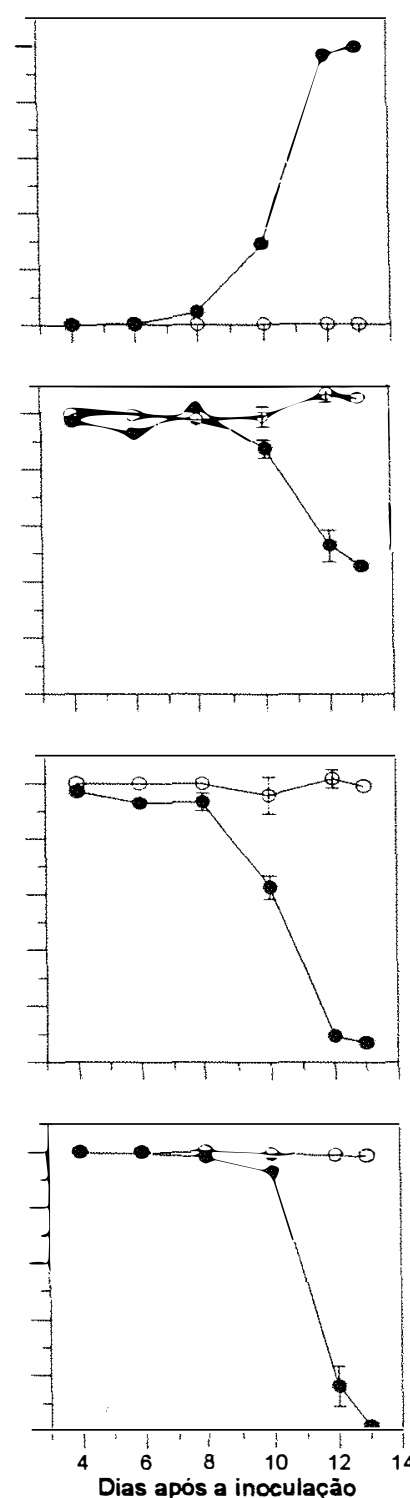

$19 \mathrm{C}$
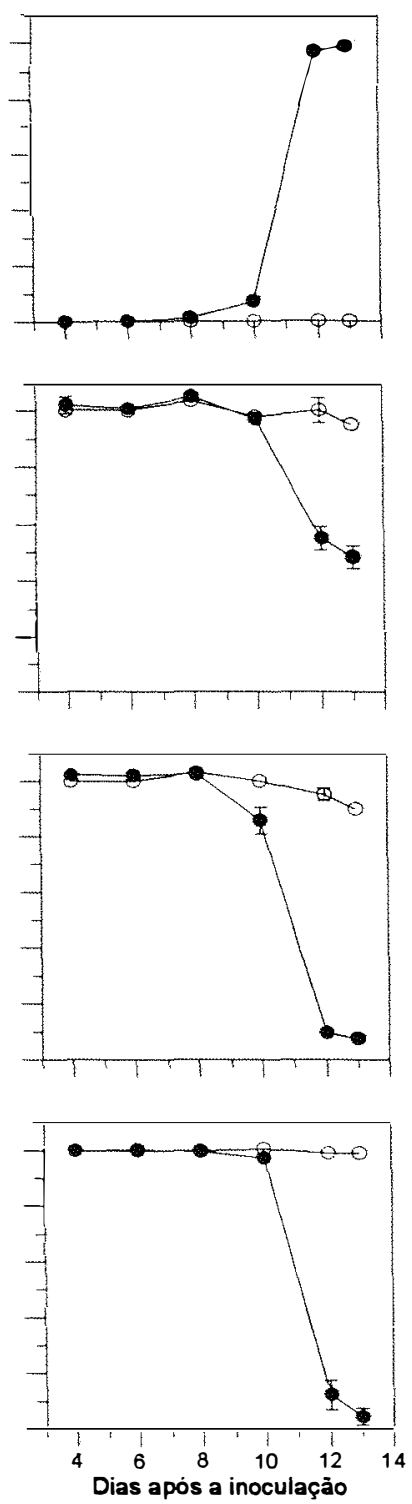

Figura 14. Valor médio (símbolo) e erro padrão (barra) da severidade de mancha angular $(\%)$, fluorescência mínima $\left(F_{0}\right)$, fluorescência máxima $\left(F_{\mathrm{m}}\right)$ e máxima eficiência quântica do fotossistema II $\left(F_{v} / F_{\mathrm{m}}\right)$ de regiões aparentemente sadias de folíolos doentes $(\mathrm{O})$ e regiões sintomáticas de folíolos doentes $(\bullet)$ da cv. Rosinha G-2 crescidos a 25,22 e $19{ }^{\circ} \mathrm{C}$ após a inoculação (as variáveis de fluorescência estão apresentadas em \% do controle). 
$25 \mathrm{C}$
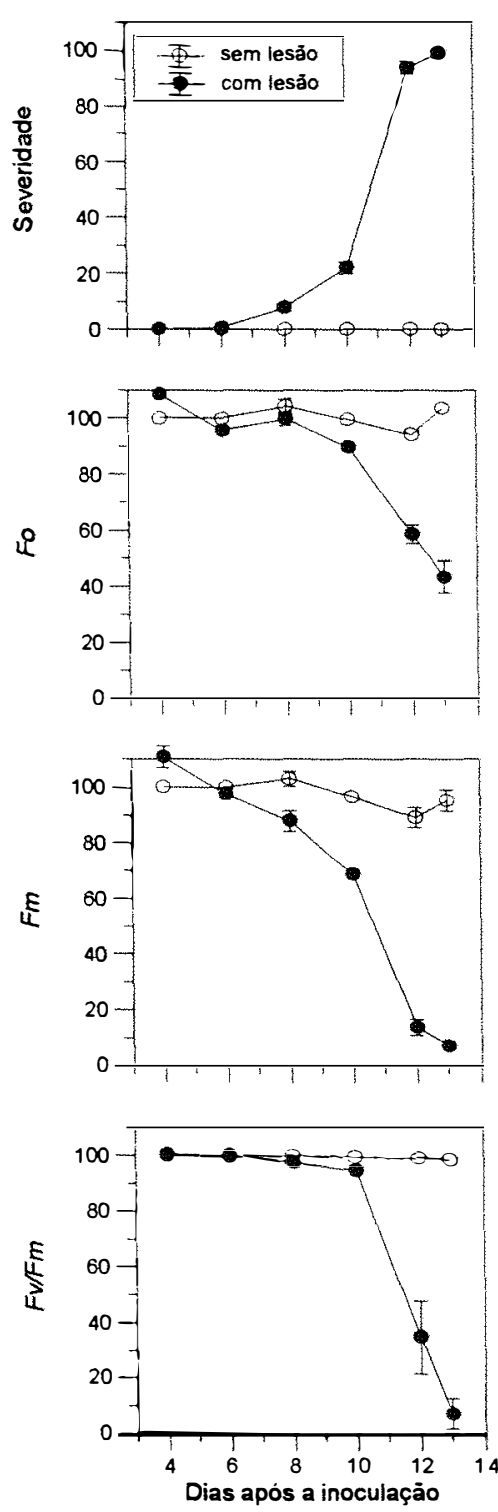

$22 \mathrm{C}$
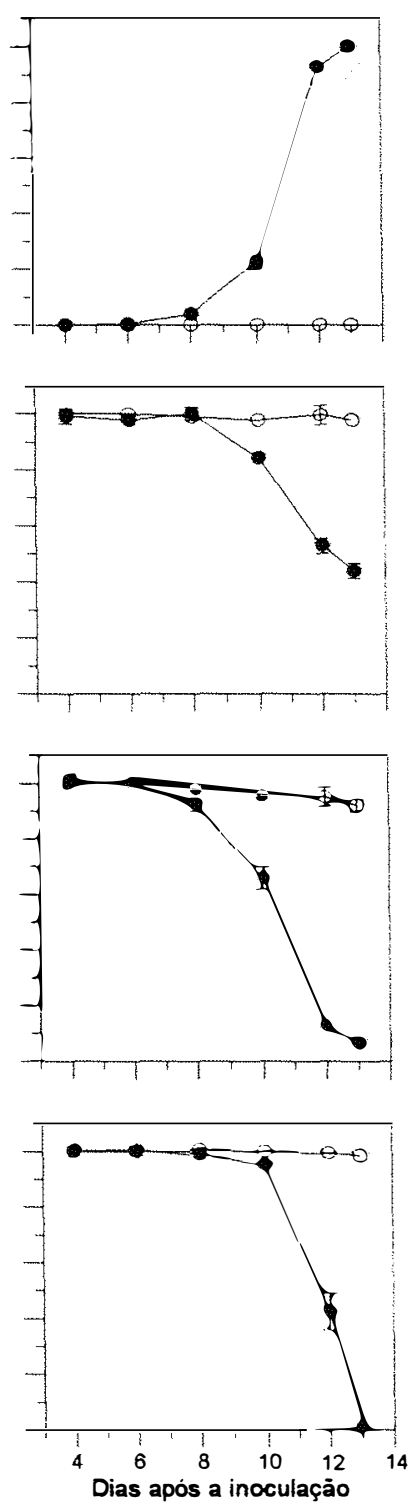

$19 \mathrm{C}$
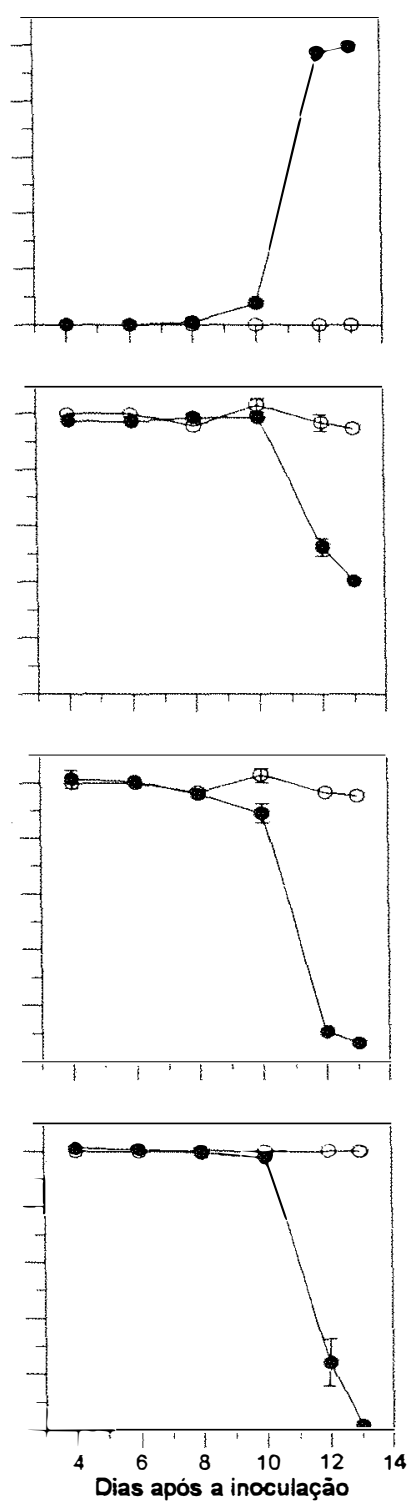

Figura 15. Valor médio (símbolo) e erro padrão (barra) da severidade de mancha angular $(\%)$, fluorescência mínima $\left(F_{0}\right)$, fluorescência máxima $\left(F_{\mathrm{m}}\right)$ e máxima eficiência quântica do fotossistema II $\left(F_{\mathrm{v}} / F_{\mathrm{m}}\right)$ de regiões aparentemente sadias de folíolos doentes (O) e regiões sintomáticas de folíolos doentes (•) da cv. Carioca Comum crescidos a 25,22 e $19{ }^{\circ} \mathrm{C}$ após a inoculação (as variáveis de fluorescência estão apresentadas em \% do controle). 
$\mathrm{Na}$ Figura 16, podem ser observadas as relações entre as variáveis $F_{0}, F_{\mathrm{m}} \mathrm{e}$ $F_{\mathrm{v}} / F_{\mathrm{m}}$ com a severidade de mancha angular quando mediu-se lesões individuais. Para as três variáveis ocorreu uma diminuição a medida que a severidade aumentou, isto é, à medida que o tamanho das lesões aumentou. Estas relações puderam ser expressas pelas seguintes eq. (2), (3) e (4):

$$
\begin{aligned}
& F_{0}=0,213-0,00107 * \operatorname{sev}\left(\mathrm{R}^{2}=0,86\right) \\
& F_{\mathrm{m}}=1,240-0,01135 * \operatorname{sev}\left(\mathrm{R}^{2}=0,94\right) \\
& F_{\mathrm{v}} / F_{\mathrm{m}}=0,811 *(1-0,00151 * \exp (0,06494 * \operatorname{sev}))\left(\mathrm{R}^{2}=0,99\right)
\end{aligned}
$$

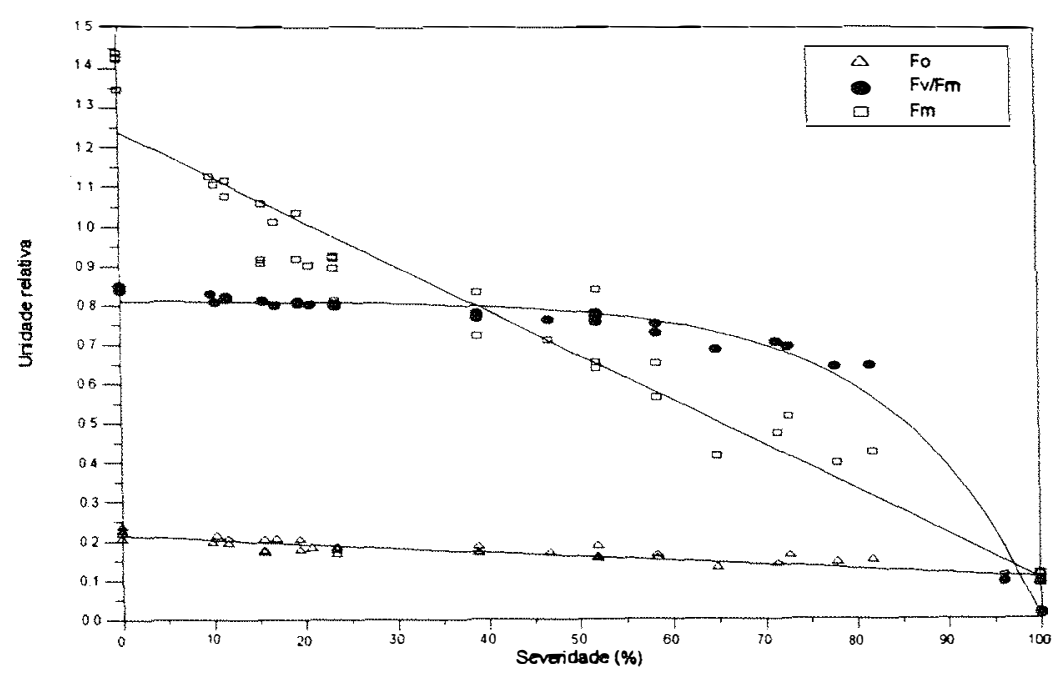

Figura 16. Fluorescência mínima $\left(F_{0}\right)$, fluorescência máxima $\left(F_{\mathrm{m}}\right)$, máxima eficiência quântica do fotossistema II $\left(F_{\mathrm{v}} / F_{\mathrm{m}}\right)$ em função da severidade de mancha angular. 


\subsubsection{Antracnose}

\subsubsection{Progresso da doença}

Os estádios de desenvolvimento da doença em cada dia após a inoculação (dai) são mostrados na Tabela 03 e, parcialmente, na Figura 17 . A 23 e $19{ }^{\circ} \mathrm{C}$ a doença progrediu mais rapidamente que a $15^{\circ} \mathrm{C}$. Entretanto, não foram observadas diferenças entre as cultivares na velocidade de aparecimento dos sintomas. Os primeiros sintomas de antracnose foram observados aos 4 dai a $23^{\circ} \mathrm{C}$, aos 5 dai a $19^{\circ} \mathrm{C}$ e aos 6 dai a $15^{\circ} \mathrm{C} \mathrm{em}$ ambas cultivares (Tabela 03). Aos 7 dai, as severidades para a cv. Carioca Comum, nas temperaturas de 23,19 e $15{ }^{\circ} \mathrm{C}$, foram respectivamente em torno de 20,25 e $13 \%$, enquanto que para a cv. Rosinha G-2 foram 15, 28 e 4 \% (Figuras 18a e 20a).

Tabela 03. Estádios de desenvolvimento da antracnose para cada temperatura em cada dia após a inoculação (dai) em que houve avaliação dos processos fisiológicos.

\begin{tabular}{|c|c|c|c|}
\hline & $15^{\circ} \mathrm{C}$ & $19^{\circ} \mathrm{C}$ & $23^{\circ} \mathrm{C}$ \\
\hline Dai & Estádio & Estádio & Estádio \\
\hline 2 & sem sintomas aparentes & sem sintomas aparentes & sem sintomas aparentes \\
\hline 3 & sem sintomas aparentes & sem sintomas aparentes & sem sintomas aparentes \\
\hline 4 & sem sintomas aparentes & sem sintomas aparentes & $\begin{array}{l}\text { inicio do aparecimento de pontos } \\
\text { escuros nas nervuras }\end{array}$ \\
\hline 5 & sem sintomas aparentes & $\begin{array}{l}\text { pequenas lesões pardo- } \\
\text { avermelhadas nas nervuras }\end{array}$ & $\begin{array}{l}\text { lesões pardo-avermelhadas nas } \\
\text { nervuras e início de pontos } \\
\text { "encharcados" }\end{array}$ \\
\hline 6 & $\begin{array}{l}\text { início do aparecimento de pontos } \\
\text { escuros nas nervuras }\end{array}$ & $\begin{array}{l}\text { lesões pardo-avermelhadas nas } \\
\text { nervuras e inicio de pontos } \\
\text { "encharcados" }\end{array}$ & $\begin{array}{c}\text { lesões pardo-avermelhadas nas } \\
\text { nervuras e aumento das áreas } \\
\text { "encharcadas" }\end{array}$ \\
\hline 7 & $\begin{array}{c}\text { lesões pardo-avermelhadas nas } \\
\text { nervuras }\end{array}$ & $\begin{array}{c}\text { lesões pardo-avermelhadas nas } \\
\text { nervuras e aumento das áreas } \\
\text { "encharcadas" }\end{array}$ & $\begin{array}{l}\text { lesões necróticas nas nervuras e } \\
\text { inicio da murcha e seca da folha }\end{array}$ \\
\hline 8 & $\begin{array}{l}\text { lesões pardo-avermelhadas nas } \\
\text { nervuras e inicio de pontos } \\
\text { "encharcados" }\end{array}$ & $\begin{array}{l}\text { lesões necróticas nas nervuras e } \\
\text { murcha e seca da folha }\end{array}$ & $\begin{array}{l}\text { lesões necróticas nas nervuras e } \\
\text { seca da folha }\end{array}$ \\
\hline
\end{tabular}



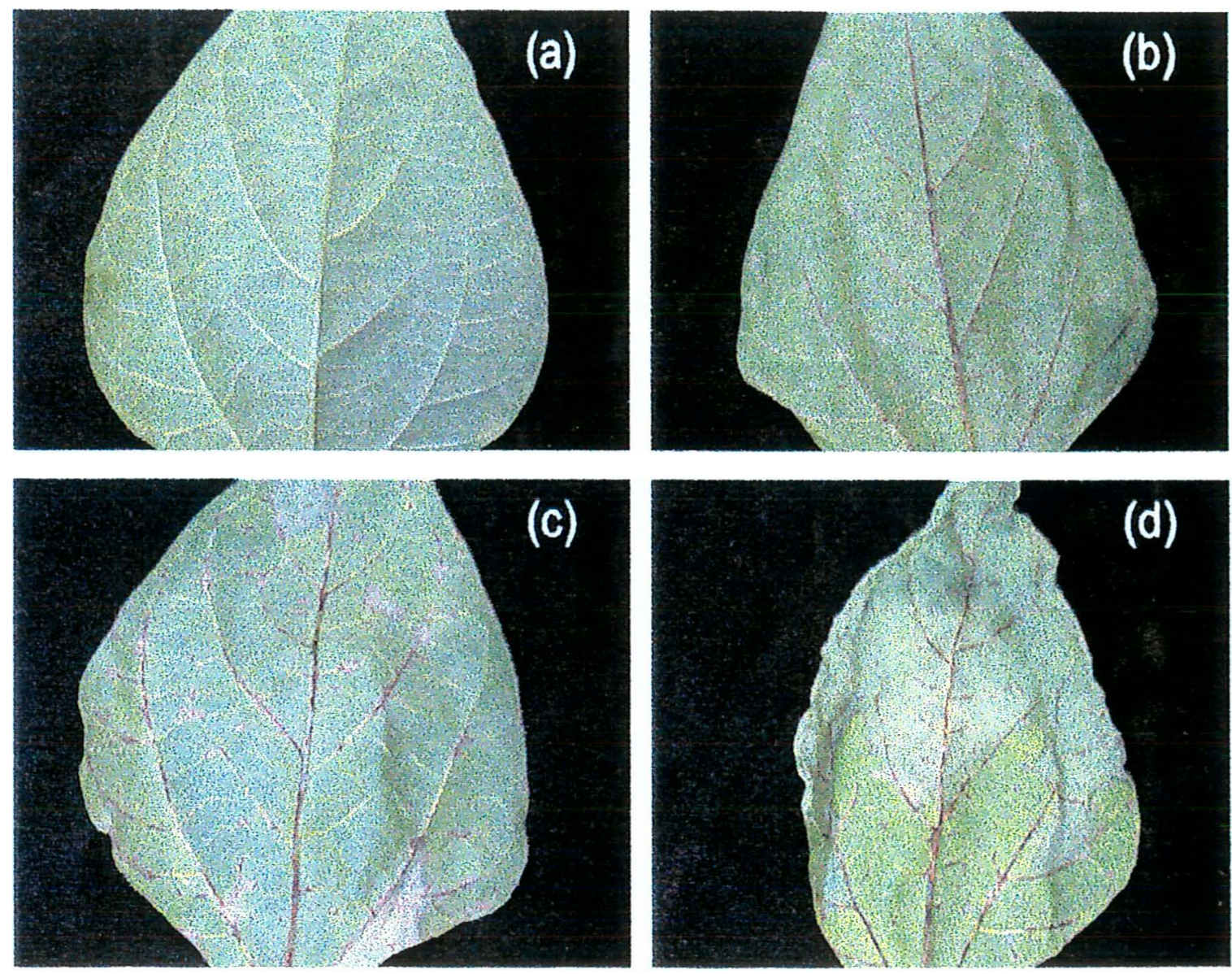

Figura 17. Estádios de desenvolvimento da antracnose do feijoeiro: (a) pequenas lesões pardo-avermelhadas nas nervuras; (b) lesões pardo-avermelhadas nas nervuras; (c) lesões pardo-avermelhadas nas nervuras e áreas "encharcadas" com início de necrose; (d) lesões pardo-avermelhadas nas nervuras e murcha e seca da folha. 

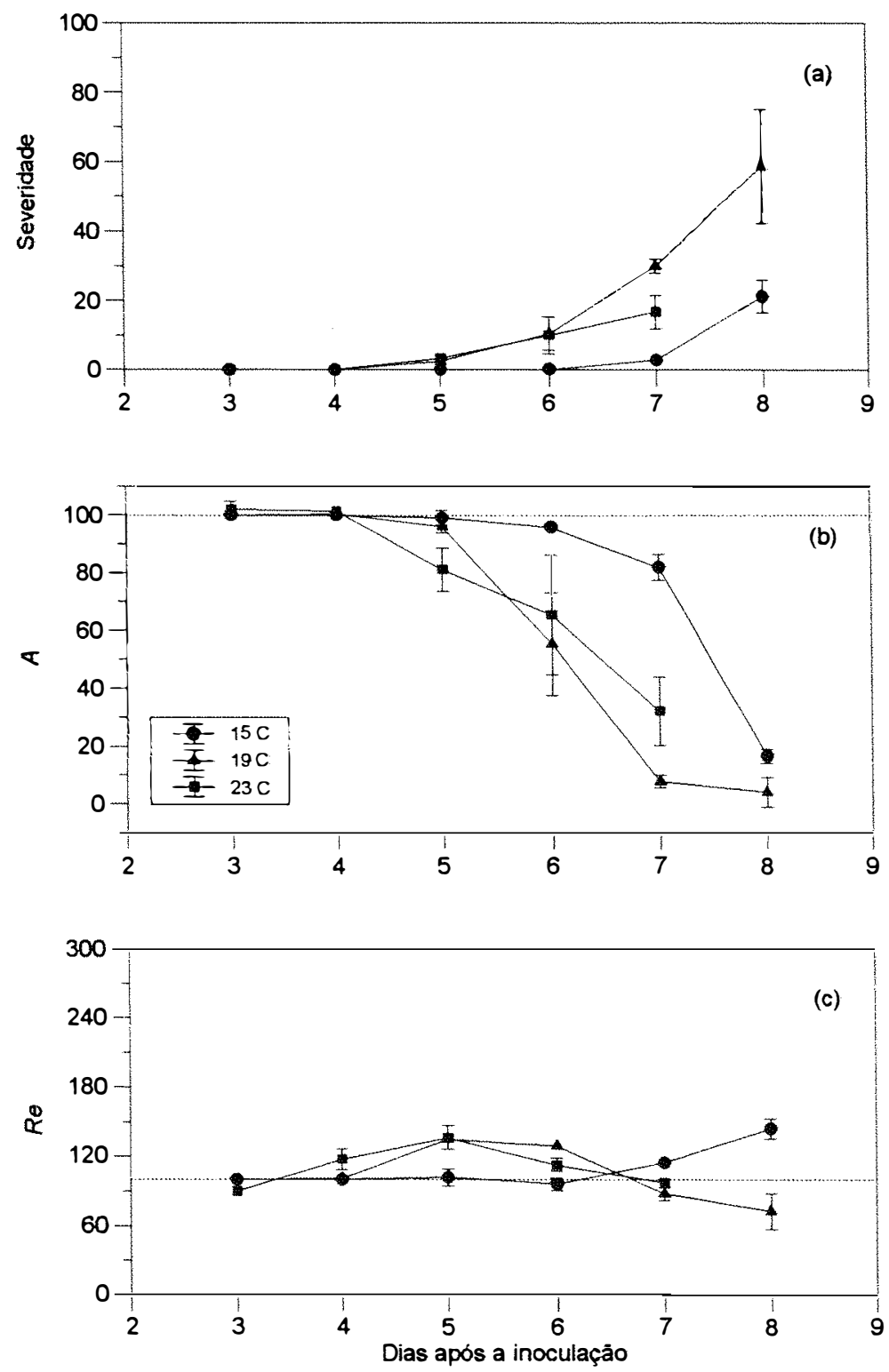

Figura 18. Valor médio (símbolo) e erro padrão (barra) da: (a) severidade de antracnose (\%), (b) taxa de assimilação líquida de $\mathrm{CO}_{2}$ (\% do controle) e (c) taxa de respiração no escuro (\% do controle) de folhas doentes da cv. Rosinha G-2 crescidas em diferentes temperaturas após a inoculação. 

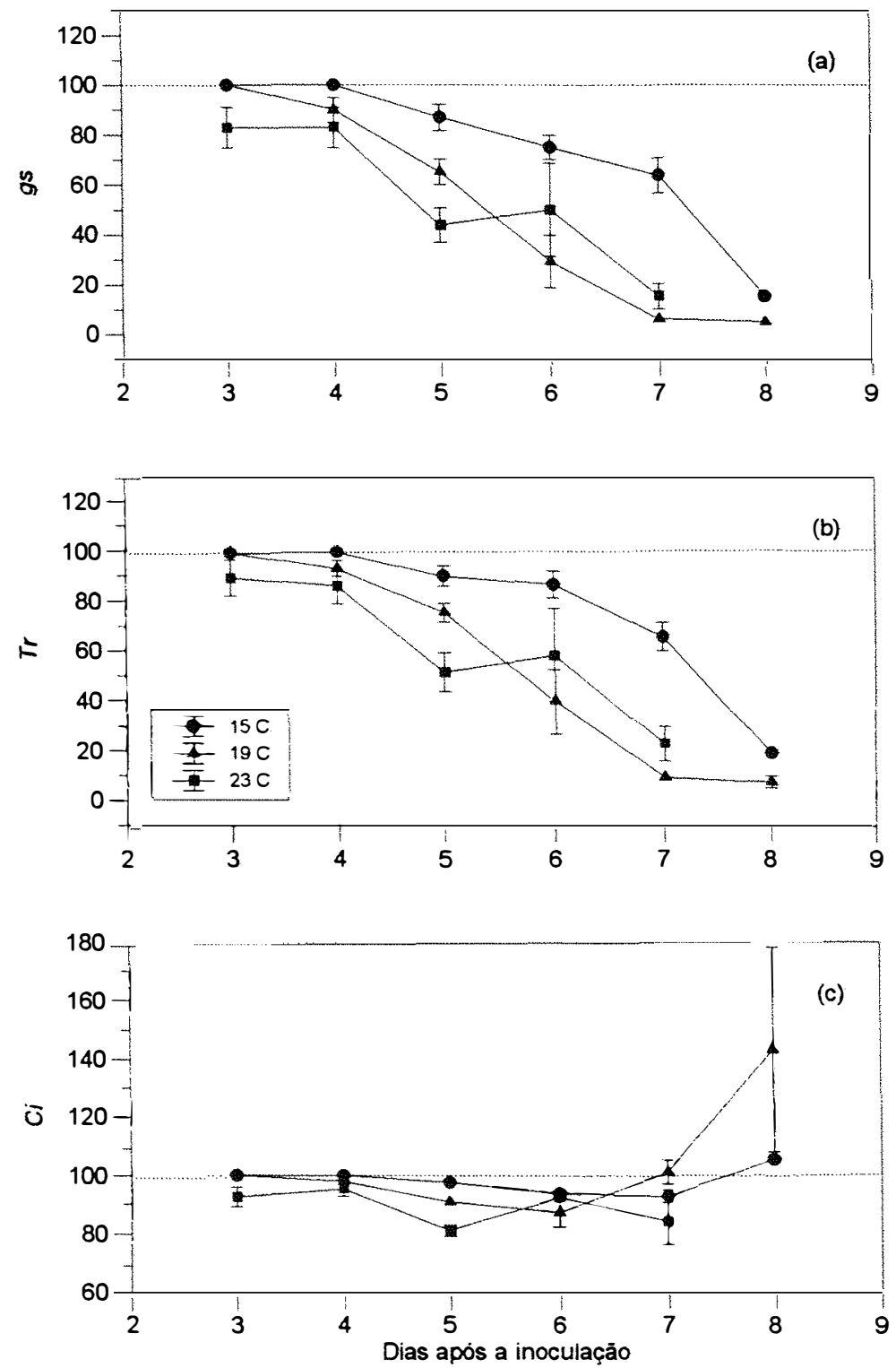

Figura 19. Valor médio (símbolo) e erro padrão (barra) da: (a) condutância estomática, (b) taxa de transpiração e (c) concentração intercelular de $\mathrm{CO}_{2}$ de folhas com antracnose da cv. Rosinha G-2 crescidas em diferentes temperaturas após a inoculação (valores em \% do controle) 

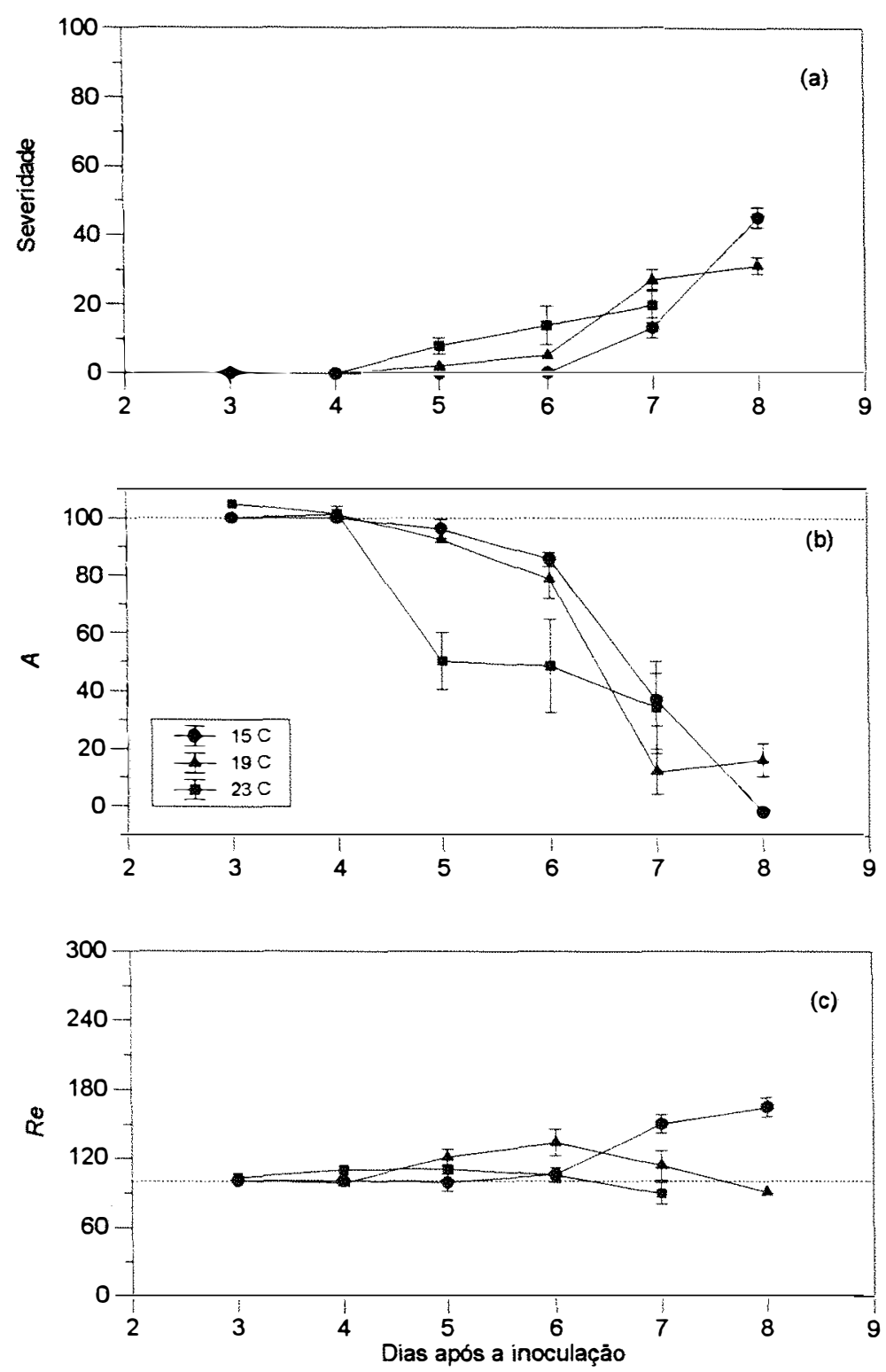

Figura 20. Valor médio (símbolo) e erro padrão (barra) da: (a) severidade de antracnose (\%), (b) taxa de assimilação líquida de $\mathrm{CO}_{2}$ (\% do controle) e (c) taxa de respiração no escuro (\% do controle) de folhas doentes da cv. Carioca Comum crescidas em diferentes temperaturas após a inoculação. 

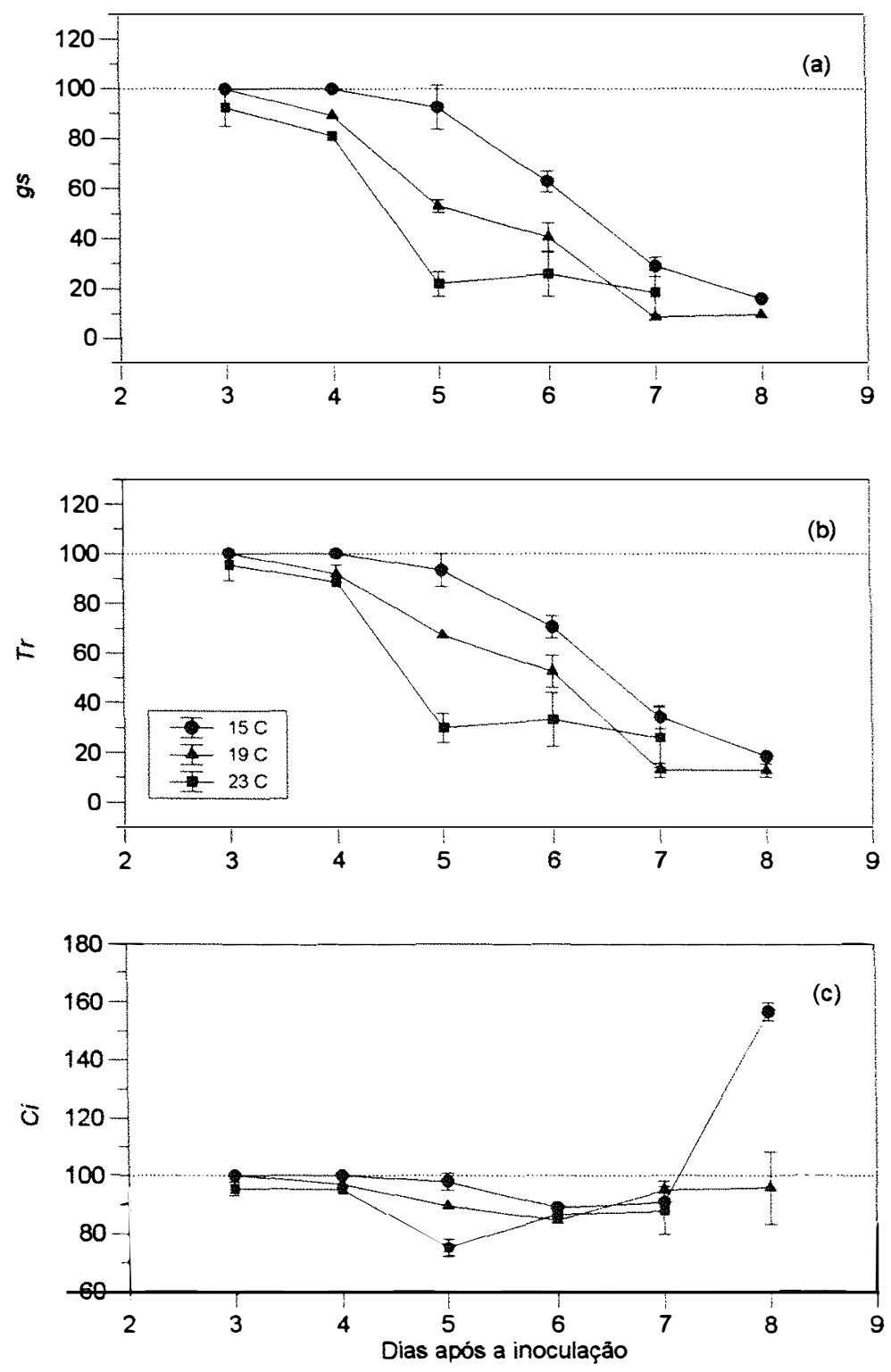

Figura 21. Valor médio (símbolo) e erro padrão (barra) da: (a) condutância estomática, (b) taxa de transpiração e (c) concentração intercelular de $\mathrm{CO}_{2}$ de folhas com antracnose da cv. Carioca Comum crescidas em diferentes temperaturas após a inoculação (valores em \% do controle). 


\subsubsection{Variáveis relacionadas com as trocas gasosas}

As Figuras 18 a e 20a mostram claramente que o efeito da temperatura foi mais evidente no atraso do progresso da doença e, conseqüentemente, as diferenças nas variáveis relacionadas com as trocas gasosas entre as folhas doentes e sadias (Figuras 1821) se manifestaram mais rapidamente quanto maior a temperatura. Quanto maior a severidade de doença maiores foram os efeitos da antracnose nas variáveis de troca gasosa.

Independentemente da temperatura e cultivar, foi observado que a $A$ das folhas doentes diminuiu em relação à taxa das folhas sadias, acompanhando o aumento da severidade $(r=-0,92 ; P=0,000)$ a medida que a doença progrediu (Figuras $18 \mathrm{~b}$ e $20 \mathrm{~b}$ ). Esta diminuição foi inicialmente observada logo após o aparecimento dos primeiros sintomas (pontos escuros nas nervuras), no estádio de lesões pardo-avermelhadas nas nervuras e início de pontos "encharcados" (entre 4-5 dai a $23{ }^{\circ} \mathrm{C}$, entre $5-6$ dai a $19{ }^{\circ} \mathrm{C}$ e aos 6 dai a $15^{\circ} \mathrm{C}$ ). Após a seca da folha ou paralisação do desenvolvimento dos sintomas a $A$ tendeu a estabilizar, como observado para a cv. Carioca Comum a 23 e $19^{\circ} \mathrm{C}$ (Figura 20b) e para a cv. Rosinha G-2 a $19{ }^{\circ} \mathrm{C}$ (Figura 18b). A proporção com que a $A$ foi reduzida nas folhas doentes foi bem maior que a proporção da área foliar com sintomas de antracnose. Aos 7 dai, as porcentagens de redução da $A$ a 23,19 e $15^{\circ} \mathrm{C}$ na $\mathrm{cv}$. Carioca Comum foram respectivamente em torno 68, 90 e 65, enquanto que na cv. Rosinha G-2 foram ao redor de 70, 92 e 19. Quando a severidade de antracnose atingiu valores acima de $30 \%$ a $A$ foi quase nula ou negativa (houve maior liberação de $\mathrm{CO}_{2}$ do que assimilação).

Foi observado um aumento da $R e$ nas folhas doentes em relação às folhas sadias já a partir do aparecimento dos primeiros sintomas, atingindo um valor máximo no estádio de lesões pardo-avermelhadas nas nervuras e áreas encharcadas (Tabela 03) com um decréscimo à medida que ocorreu a murcha e seca da folha (Figuras 18c e 20c). Na temperatura de $15^{\circ} \mathrm{C}$ o decréscimo não foi observado porque os sintomas não atingiram 
o estádio de murcha até a última data de avaliação. O valor máximo do aumento da $\operatorname{Re}$ a $23{ }^{\circ} \mathrm{C}$ foi 10 a $40 \%$, a $19{ }^{\circ} \mathrm{C}, 40 \%$ e, a $15{ }^{\circ} \mathrm{C}$, maior que $60 \%$.

Nas Figuras 19a, 19b, 21 a e 21 b foi observada uma relação negativa entre a severidade e as variáveis $g s(r=-0,80 ; P=0,000)$ e $\operatorname{Tr}(r=-0,84 ; P=0,000)$, ao contrário do observado anteriormente para as folhas com ferrugem. Antes do início do aparecimento dos sintomas os valores de $g s$ e $\operatorname{Tr}$ nas folhas infectadas foram bastante similares aos valores das folhas sadias, mas um pouco antes do aparecimento dos sintomas já foram observadas menores gs e $\operatorname{Tr}$ nas folhas doentes, cujos valores foram diminuindo conforme o progresso da doença e aumento da severidade. Da mesma forma que para a mancha angular, foi detectada a relação positiva tanto entre $g s$ e $\operatorname{Tr}(r=0,99$; $P=0,000)$ quanto entre $g s$ e $A(r=0,93 ; P=0,000)$ nas folhas com antracnose.

Diferentemente da ferrugem e da mancha angular no início, a $\mathrm{Ci}$ das folhas doentes, que antes do aparecimento dos sintomas apresentava valores próximos aos das folhas sadias, diminuiu acompanhando a diminuição da $g s$ a partir do início dos sintomas $(r=0,88 ; P=0,000)$. A redução na $C i$ foi máxima até o aparecimento de pontos "encharcados" no limbo foliar próximo às nervuras ou quando a região avaliada apresentava menos de $20 \%$ de severidade (Figuras 19c e 21c). As porcentagens médias de redução da $C i$ nas folhas doentes foram aproximadamente 23, 17 e 10 nas temperaturas de 23,19 e $15^{\circ} \mathrm{C}$, respectivamente. A partir deste limiar de severidade em torno de $20 \%$ a relação positiva entre $C i$ e $g s$ se inverteu, isto é, a $C i$ aumentou enquanto a gs continuou decaindo. O mesmo ocorreu para a relação entre $C i$ e $A$, que antes dos $20 \%$ de severidade tiveram uma relação positiva $(r=0,70 ; P=0,000)$. A relação entre a $\mathrm{Ci}$ e a $\mathrm{Re}$ não foi significativa $(P=0,704)$.

\subsubsection{Variáveis relacionadas com a emissão de fluorescência da clorofila $a$}

O efeito da severidade de antracnose nas variáveis de fluorescência das duas cultivares de feijoeiro pode ser observado na Figura 22. A variável $F_{0}$ praticamente não foi alterada em função da severidade, com a regressão linear não significativa a $1 \%$ para 
as duas cultivares, da mesma forma que os resultados obtidos para a ferrugem. Contudo, a variável $F_{\mathrm{m}}$ foi reduzida significativamente conforme o aumento da severidade de antracnose. As retas obtidas pela regressão linear tiveram altos valores de coeficiente de determinação e foram bastante semelhantes entre as duas cultivares como mostrado pelas eq. (5) e (6) para as cultivares Rosinha G-2 e Carioca Comum respectivamente.

$$
\begin{aligned}
& F_{\mathrm{m}}=1,231-0,0109 * \operatorname{sev}\left(\mathrm{R}^{2}=0,95\right) \\
& F_{\mathrm{m}}=1,228-0,0108 * \operatorname{sev}(\mathrm{R} 2=0,97)
\end{aligned}
$$

Conseqüentemente, os valores de $F_{\mathrm{v}} / F_{\mathrm{m}}$ foram também reduzidos e explicados pelas eq. (7) e (8) para as cultivares Rosinha G-2 e Carioca Comum, respectivamente, com $\mathrm{R}^{2}$ de 0,99 em ambos os casos.

$$
\begin{aligned}
& F_{\mathrm{v}} / F_{\mathrm{m}}=0,855 *(1-0,06424 * \exp (0,02775 * \mathrm{sev})) \\
& F_{\mathrm{v}} / F_{\mathrm{m}}=0,868 *(1-0,05202 * \exp (0,02948 * \mathrm{sev}))
\end{aligned}
$$

As regiões aparentemente sadias de folíolos doentes comportaram-se de maneira similar às regiões de folíolos sadios, mostrando que as primeiras não tiveram sua eficiência fotossintética muito alterada pelo patógeno. Nas regiões que apresentaram necrose inicial das nervuras (severidade de 5 a $35 \%$ ), apesar da $F_{\mathrm{m}}$ ser reduzida, não foram observadas grandes reduções na $F_{\mathrm{v}} / F_{\mathrm{m}}$, permanecendo o valor dentro da faixa de 0,75-0,85 considerado normal em plantas sadias não estressadas. Nas regiões com necrose adiantada das nervuras e início de murcha (severidade de 50 a $90 \%$ ) já se detectou o efeito do estresse causado por este patógeno na folha infectada, tendo menores valores de $F_{\mathrm{v}} / F_{\mathrm{m}}$. Na faixa de severidade $95-100 \%$, na qual as regiões avaliadas mostram-se praticamente secas os valores de $F_{\mathrm{v}} / F_{\mathrm{m}}$ foram quase nulos. 

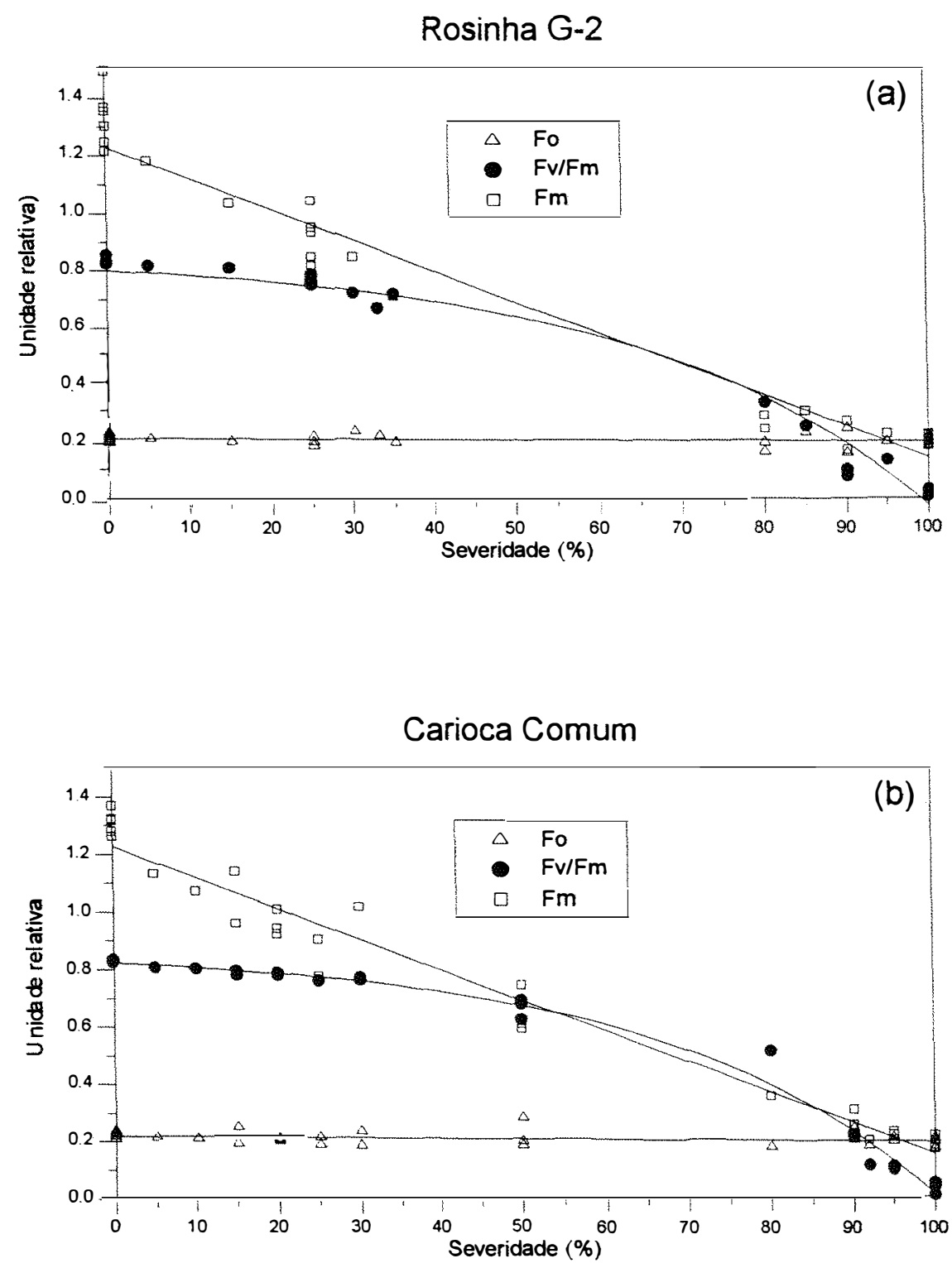

Figura 22. Fluorescência mínima $\left(F_{0}\right)$, fluorescência máxima $\left(F_{\mathrm{m}}\right)$ e máxima eficiência quântica do fotossistema II $\left(F_{\mathrm{v}} / F_{\mathrm{m}}\right)$ em função da severidade de antracnose (\%) nos folíolos da primeira folha trifoliolada da cv. Rosinha G-2 (a) e Carioca Comum (b) crescidos a $19^{\circ} \mathrm{C}$ após a inoculação. 


\subsection{Discussão}

O efeito da temperatura, na qual as plantas foram mantidas após a inoculação, foi mais evidente sobre a velocidade de desenvolvimento da doença e do aparecimento dos seus sintomas que sobre os processos fisiológicos das plantas de feijoeiro, sendo as alterações observadas nestes processos decorrência da maior ou menor severidade de doença presente no momento da avaliação. As temperaturas constantes em que as plantas foram mantidas, de 15 a $25^{\circ} \mathrm{C}$, não constituem fatores de estresse às plantas de feijoeiro, cuja temperatura média ideal corresponde a $21{ }^{\circ} \mathrm{C}$ e tem como temperatura basal e máxima 10 e $30^{\circ} \mathrm{C}$ respectivamente (Fancelli, 1990). Desta forma, pouca alteração nos processos fisiológicos poderiam ser esperados com relação às temperaturas testadas independentemente da presença dos patógenos.

Para todas as doenças, os efeitos das temperaturas sobre o período de incubação, período de latência e crescimento das lesões confirmam os dados anteriormente encontrados na literatura. No caso da ferrugem, o período de incubação em torno de 5 a 7 dias e de latência em torno de 7 a 9 dias também foram observados anteriormente na faixa de temperatura de 15 a $23{ }^{\circ} \mathrm{C}$, sendo menor quanto maior a temperatura (Bacchi, 1993; Bassanezi, 1995; Code et al., 1985). Da mesma forma, a maior a taxa de crescimento das pústulas ocorreu na maior temperatura, como observado previamente por Bassanezi (1995) e Imhoff et al. (1982). Para a mancha angular, o período de incubação também diminui com o aumento da temperatura, sendo os valores encontrados, 6 dias a $25^{\circ} \mathrm{C}$ e 7 dias a 19 e $22{ }^{\circ} \mathrm{C}$, próximos aos encontrados por outros autores (Bassanezi, 1995; Campos \& Zak, 1980; Dalla Pria, 1997; Llanos, 1957; Olave, 1958). A temperatura também afetou a taxa de crescimento das lesões, atingindo um máximo à medida que se aproxima do ponto ótimo de desenvolvimento da doença, $24^{\circ} \mathrm{C}$ (Dalla Pria, 1997). Quanto à antracnose, o período de incubação de 4 dias a $23{ }^{\circ} \mathrm{C}, 5$ dias a $19{ }^{\circ} \mathrm{C}$ e 6 dias a $15^{\circ} \mathrm{C}$ estão de acordo com os dados encontrados por Dalla Pria (1997). Da mesma forma, o desenvolvimento dos sintomas e aumento da severidade de 
doença é ótimo a $17^{\circ} \mathrm{C}$ (Crispín et al., 1976; Dalla Pria, 1997; Schwartz, 1991; Tu, 1992) como constatado no presente trabalho.

Como as doenças causaram diferentes tipos de alterações nos processos fisiológicos das folhas de feijoeiro doentes, a discussão foi feita separadamente para cada doença.

\subsubsection{Ferrugem}

Os efeitos da infecção por $U$. appendiculatus na atividade fotossintética do feijoeiro têm sido descritos por vários pesquisadores. Entre os principais efeitos observados durante a infecção por este patógeno está o decréscimo da $A$ após o aparecimento dos sintomas, (Bassanezi, 1995; Lopes, 1999; Livne, 1964; Raggi, 1978; Raggi, 1980) comumente associado às alterações nos cloroplastos (Sziráki et al., 1984) e à redução do conteúdo de clorofila nas folhas doentes (Bassanezi, 1995; Lopes, 1999; Moll et al., 1995; Stangarlin, 1999; Sziráki et al., 1984; Wagner \& Boyle, 1995).

Esta redução da capacidade de assimilação de $\mathrm{CO}_{2}$ aumentou a medida que a doença evoluiu e a severidade aumentou, entretanto não foi totalmente explicada pela redução da área foliar verde, indicando que a eficiência fotossintética da área aparentemente sadia remanescente foi ligeiramente afetada, como também observado por Bassanezi (1995) e Lopes (1999). Neste caso, o aumento da resistência estomática ou da resistência à carboxilação nas regiões entre as pústulas poderiam explicar esta menor taxa fotossintética. Se o fechamento dos estômatos fosse a causa da redução da assimilação de $\mathrm{CO}_{2}$, uma redução na gs e $\mathrm{Ci}$ seria esperada, ao contrário do que foi observado neste trabalho. A gs permaneceu praticamente estável e a $C i$ aumentou, enquanto a $A$ foi reduzida, indicando que a $A$ não foi limitada pela menor $C i$ devido a um aumento na resistência à entrada de $\mathrm{CO}_{2}$ na folha doente. Outras alterações como mudanças nos padrões de translocação de fotoassimilados e acúmulo de carboidratos (Inman, 1962; Livne \& Daly, 1966; Sziráki et al., 1984; Wagner \& Boyle, 1995; Wang, 1961; Zaki \& Durbin, 1965) e aumento da atividade da invertase ácida (Wagner \& Boyle, 1995) nos 
tecidos ao redor das pústulas, que levariam a uma realimentação negativa do Ciclo de Calvin e à redução da atividade da Rubisco (Stangarlin, 1999), aumentariam a resistência à carboxilação, contribuindo para a menor atividade fotossintética nestas regiões assintomáticas.

A fluorescência da clorofila $a$ reflete a eficiência da utilização da luz no PSII. A inibição das reações fotoquímicas primárias, do transporte de elétrons ou do metabolismo do carbono causada por um estresse pode afetar a função do PSII e ser expressa como mudanças na produção de fluorescência (Bolhár-Nordenkampf \& Öquist, 1993).

A $F_{0}$ representa a emissão de fluorescência das moléculas de clorofila $a$ na antena coletora de luz associada com o PSII antes que a energia de excitação seja usada para o transporte de elétrons (Krause \& Weis, 1984) sendo, portanto, independente dos eventos fotoquímicos, mas dependente do conteúdo de clorofila na ultraestrutura das membranas tilacóides. Neste trabalho não foi constatado um leve aumento na $F_{0}$ das folhas infectadas durante o estádio de "fleck" como observado por Lopes (1999). A $F_{0}$ permaneceu semelhante ao controle até a última avaliação, quando na cv. Rosinha G-2 diminuiu e na cv. Carioca Comum aumentou. A diminuição da $F_{0}$ pode ser explicada pela perda de clorofila dos tecidos, mais pronunciada no final da esporulação e início da senescência foliar. Já o aumento da $F_{0}$ na cv. Carioca poderia ser causado pela inativação de alguns centros de reação do PSII ou pela desorientação de uma porção das moléculas de clorofila na membrana tilacóide durante a colonização do tecido pelo patógeno (Lopes, 1999; Scholes \& Farrar, 1985).

A $F_{\mathrm{m}}$ representa a medida da condição de oxidação-redução dos aceptores de elétrons entre o PSII e o PSI e é um indicador direto da atividade do PSII (Scholes \& Farrar, 1985). Estresses que causam danos à membrana tilacóide usualmente reduzem a $F_{\mathrm{m}}$. Como observado anteriormente por Bassanezi (1995) e Lopes (1999), o valores de $F_{\mathrm{m}}$ nas regiões com ferrugem foram reduzidos a partir do início da esporulação independentemente da cultivar. Entretanto, as regiões aparentemente sadias de foliolos doentes se comportaram da mesma forma que os folíolos sadios, mostrando que as primeiras não tiveram alterações na membrana tilacóide pelo patógeno. 
A $F_{\mathrm{v}} / F_{\mathrm{m}}$ fornece informações sobre a eficiência fotossintética potencial do PSII e é freqüentemente designada como um índice de vitalidade (Moll et al., 1995). Neste estudo, como no trabalho de Bassanezi (1995), muito pouca redução da $F_{\mathrm{v}} / F_{\mathrm{m}}$ foi encontrada nas regiões com sintomas de folíolos com ferrugem, pois estas regiões avaliadas continham tanto tecido doente como sadio. Contudo, em estudos anteriores com este mesmo patossistema (Lopes, 1999; Moll et al., 1995), avaliando-se apenas na área da lesão, foram observadas reduções significativas da $F_{\mathrm{v}} / F_{\mathrm{m}}$ principalmente devido à diminuição da $F_{\mathrm{m}}$. A redução na $F_{\mathrm{v}} / F_{\mathrm{m}}$ indica que a região das lesões tem uma menor capacidade de transporte de elétrons e geração de ATP e NADPH e, portanto, espera-se uma menor $A$. Nas regiões aparentemente sadias, onde os valores de $F_{\mathrm{v}} / F_{\mathrm{m}}$ continuaram iguais aos das folhas não-inoculadas, a diminuição da $A$ deve ser devida a outro fator relacionado ao metabolismo do carbono, como uma redução na atividade ou quantidade de enzimas do Ciclo de Calvin ou acúmulo de carboidratos descrito anteriormente.

Poucas mudanças foram observadas na $\operatorname{Tr}$ das folhas doentes, uma vez que o funcionamento dos estômatos também não foi muito alterado. A elevação da $\operatorname{Tr}$ causada por fungos causadores de ferrugens tem sido atribuída à ruptura da epiderme pelo patógeno e não por danos ao mecanismo de abertura e fechamento dos estômatos (Duniway \& Durbin, 1971; Owera et al., 1981). Entretanto, em niveis maiores de severidade, as folhas infectadas pelas ferrugens do trigo e do milho tiveram uma $\operatorname{Tr}$ por área foliar menor que as folhas não infectadas (McGrath \& Pennypacker, 1990; Shtienberg, 1992).

$\mathrm{O}$ aumento da $R e$ nas folhas doentes a partir do aparecimento dos primeiros sintomas também está de acordo com trabalhos prévios sobre a mudança da respiração foliar neste patossistema (Bassanezi, 1995; Daly et al., 1961; Lopes, 1999; Livne, 1964; Raggi, 1978; Raggi, 1980). A taxa respiratória atingiu um valor máximo e se manteve neste valor durante todo o processo de esporulação, indicando que neste estádio ocorreu uma intensa atividade metabólica do patógeno e das células da planta para suprir a demanda energética necessária à produção de esporos do fungo. Este fato é suportado pelas observações de Wagner \& Boyle (1995) que constataram um aumento da atividade 
da invertase ácida, aumento da hidrólise do amido e mobilização da glicose durante o processo de esporulação da ferrugem do feijoeiro. Segundo estes pesquisadores, os esporos representam um enorme efluxo de metabólitos e energia. $\mathrm{O}$ aumento da $R e$ e a manutenção da gs quase que constante contribuíram para o aumento da $\mathrm{Ci}$ detectada nas folhas com ferrugem.

\subsubsection{Mancha angular}

Nas interações entre patógeno hemibiotrófico e hospedeiro, como no caso do patossistema $P$. griseola-feijoeiro, nas quais o processo doença termina em necrose do tecido foliar, a $A$ é afetada principalmente pela perda de clorofila a partir do aparecimento dos primeiros sintomas (Goodman et al., 1986). Bassanezi (1995) e Stangarlin (1999) observaram uma redução no conteúdo total de clorofila de folhas com mancha angular em relação à folhas sadias um pouco maior que a proporção da área foliar ocupada pelas lesões necróticas, indicando uma redução da clorofila nos tecidos adjacentes às lesões. Em outros patossistemas a redução do conteúdo de clorofila tem sido resultante da ação de enzimas degradadoras de organelas e cloroplastos ou de toxinas produzidas e liberadas pelo patógeno durante a sua colonização (Fulton et al., 1964; Janardhanan \& Husain, 1984; Navarre \& Wolpert, 1999; Rasmussen \& Scheffer, 1988), porém nada ainda foi relatado para este patossistema e estudos nesse sentido necessitam ainda ser feitos.

Como a simples redução da área foliar pela presença das manchas não explicou totalmente a redução da $A$, conclui-se que o tecido verde remanescente das folhas infectadas teve sua eficiência fotossintética diminuída, como também foi sugerido por Bassanezi (1995) e Stangarlin (1999). Vários outros patossistemas em que a eficiência fotossintética foi diminuída nos tecidos aparentemente sadios das folhas doentes foram relatados na literatura, como por exemplo Cercospora arachidicola e Cercosporidium personatum-amendoim (Boote et al., 1980), Alternaria alternata-algodoeiro (Ephrath et al., 1989) e Pyricularia oryzae-arroz (Bastiaans, 1991). No caso da mancha angular, foi constatado um declínio da $g s$ juntamente com a diminuição da $A$ pelas folhas doentes, 
porém se o fechamento dos estômatos fosse o fator limitante para a assimilação de $\mathrm{CO}_{2}$, uma redução também na $C i$ seria esperada, o que não foi observado neste trabalho, pelo contrário, a $C i$ aumentou, da mesma forma que para a ferrugem. Portanto, fatores que levam ao aumento da resistência à carboxilação seriam os principais responsáveis por esta redução na $A$ da região entre as lesões. Stangarlin (1999), estudando este mesmo patossistema, observou reduções na atividade da Rubisco nos tecidos entre as lesões e que juntamente com a perda de clorofila nestas regiões explicariam a redução da $A$.

Os menores valores de $F_{0}$ e $F_{\mathrm{m}}$ observados nas regiões com lesões a partir do aparecimento dos sintomas de mancha angular, indicam primeiramente que houve a redução no conteúdo de clorofila nos tecidos desta região e que também houveram danos na membrana tilacóide. Como conseqüência disto, foram observadas reduções nos valores de $F_{\mathrm{v}} / F_{\mathrm{m}}$, sugerindo que a região das lesões teve a eficiência quântica do PSII reduzida, incluindo menor capacidade de transporte de elétrons e geração de ATP e NADPH. Estes resultados são semelhantes aos encontrados por Bassanezi (1995) para este mesmo patossistema. As regiões aparentemente sadias de folíolos doentes comportaram-se de modo similar aos folíolos sadios, como no caso da ferrugem, mostrando que as primeiras não tiveram sua eficiência quântica do PSII alterada pelo patógeno e que, provavelmente, a redução da eficiência fotossintética nesta região seja causada por outro fator ligado ao metabolismo do carbono.

Reduções da $\operatorname{Tr}$ em folhas infectadas por patógenos causadores de manchas foliares são comumente relatadas e associadas à redução da área foliar, ao fechamento dos estômatos provocado pelos patógenos, diminuição dos espaços no interior da folha pelas hifas e obstrução dos tecidos condutores e estômatos (Cayon et al., 1996; Ephrath et al., 1989; Martin, 1986; Shtienberg, 1992). No presente trabalho, o decréscimo da $\mathrm{Tr}$ nas folhas com mancha angular foi diretamente relacionado com o decréscimo da gs e, portanto, com o fechamento dos estômatos.

Em folhas infectadas com patógenos necrotróficos ou hemibiotróficos, freqüentemente ocorre um aumento da $R e$ para suprir a demanda provocada pela acelerada atividade metabólica das células do hospedeiro relacionado, principalmente, à 
produção e mobilização de mecanismos de defesa das células (Agrios, 1997; Leite \& Pascholati, 1995; Lucas, 1998). Além destes, outros mecanismos, como o desacoplamento do transporte mitocondrial de elétrons da síntese de ATP, a perda da compartimentalização de enzimas e metabólitos-chaves e o acúmulo de amido e açúcares solúveis, estariam relacionados com o aumento da $R e$ em tecidos doentes (Hutcheson \& Buchanan, 1983). No caso da mancha angular, o aumento da respiração ocorreu logo após o aparecimento dos sintomas, rapidamente atingiu um pico e depois diminuiu com o avanço da necrose dos tecidos da planta. Resultados semelhantes foram observados neste mesmo patossistema (Bassanezi, 1995) e em outros patossistemas envolvendo fungos necrotróficos ou hemibiotróficos, como no caso da infecção de cevada por Pyrenophora teres (Smedegaard-Petersen, 1984) ou Rynchosporium secalis (Martin, 1986). Freqüentemente tem sido sugerido que este aumento deve-se principalmente à respiração do hospedeiro e que a participação direta do patógeno é negligivel, apesar da extensão na qual o fungo participe não seja ainda clara (Agrios, 1997; Goodman et al., 1986, Lucas, 1998).

\subsubsection{Antracnose}

O impacto de $C$. lindemuthianum nos processos fisiológicos das folhas infectadas está associado com a fase necrotrófica da infecção. Nesta fase ocorre uma extensiva dissolução das paredes celulares à medida que o patógeno avança no tecido vascular da folha durante a colonização (Wijesundera et al., 1989).

Menores $A$ nos folíolos com antracnose só foram percebidas a partir do aparecimento dos primeiros sintomas caracterizados por pontos escuros nas nervuras. Com o progresso dos sintomas, a $A$ foi drasticamente reduzida, corroborando os resultados de Bassanezi et al. (1997) e Lopes (1999), que observaram menor $A$ quanto maior a severidade da antracnose nas folhas de feijoeiro. Resultados semelhantes foram observados por Wong \& Thrower (1978a) em folhas de Vigna sesquipedalis infectadas com C. lindemuthianum. Da mesma forma que nos trabalhos de Bassanezi et al. (1997) e 
Lopes (1999), o decréscimo da $A$ foi muito maior que a redução da área foliar verde. Esta menor eficiência fotossintética das áreas aparentemente sadias poderia ser explicada tanto pelo aumento da resistência estomática como pela resistência à carboxilação. A ruptura dos vasos condutores e o bloqueio do fluxo normal de água e fotoassimilados para as demais regiões da folha certamente leva ao fechamento dos estômatos e diminuição da $T r$. Ao contrário do observado para ferrugem e mancha angular, a redução da $g s$ foi responsável pela menor $C i$ nas folhas doentes e se tornou o principal fator limitante para a capacidade de assimilação de $\mathrm{CO}_{2}$ na folha, concordando com as observações de Bassanezi et al. (1997) e Lopes (1999). Quanto ao acúmulo de carboidratos que, por sua vez, causariam diminuição da taxa de assimilação de $\mathrm{CO}_{2}$, Wong \& Thrower (1978b) observaram um pequeno acúmulo somente durante os primeiros dias da patogênese.

A $F_{0}$ praticamente não foi alterada pela antracnose, mesmo em altos níveis de severidade, que deve ser devido à manutenção do conteúdo de clorofila nos primeiros estádios de desenvolvimento desta doença, como observado por Lopes (1999). Contudo, a variável $F_{\mathrm{m}}$ foi reduzida significativamente a partir dos primeiros sintomas e continuou diminuindo conforme o aumento da severidade de antracnose, confirmando as observações de Lopes (1999). Nas regiões que apresentaram necrose inicial das nervuras, apesar da $F_{\mathrm{m}}$ ser reduzida, não foram observadas grandes reduções na $F_{\mathrm{v}} / F_{\mathrm{m}}$, permanecendo o valor dentro da faixa de $0,75-0,85$ considerado normal em plantas sadias não estressadas. Nas regiões com necrose adiantada das nervuras e início de murcha, valores de $F_{\mathrm{v}} / F_{\mathrm{m}}$ significativamente menores foram observados. Nas regiões avaliadas praticamente secas, os valores de $F_{\mathrm{v}} / F_{\mathrm{m}}$ foram quase nulos, indicando destruição da clorofila e a morte dos tecidos. Existe claramente um desbalanço entre a drástica inibição da $A$ e a moderada redução nas reações fotoquímicas nas folhas de feijoeiro com antracnose. Raggi (1995) observou algo similar para folhas de pessegueiro infectadas com Taphrina deformans e sugeriu que a refixação do $\mathrm{CO}_{2}$ liberado pela respiração estimulada poderiam parcialmente explicar esta disparidade. Segundo Lopes (1999), esta explicação poderia ser aplicada também para a antracnose do feijoeiro uma vez que a 
respiração foi estimulada pela doença em níveis baixos de severidade. Por sua vez, do mesmo modo que para a ferrugem e para a mancha angular, as regiões aparentemente sadias de folíolos doentes comportaram-se de maneira similar aos folíolos sadios.

$\mathrm{O}$ aumento da $R e$ em folhas infectadas com $C$. lindemuthianum tem sido constatado tanto em feijoeiro (Lopes, 1999) como em V. sesquipedalis (Wong \& Thrower, 1978a) a partir do aparecimento dos sintomas necróticos da antracnose. Os mecanismos apresentados para explicar o aumento da $R e$ em folhas com a mancha angular servem também para a antracnose.

Este estudo permitiu distinguir diferentes modos de ação dos patógenos foliares do feijoeiro durante a infecção e o processo de colonização do hospedeiro. Patógenos biotróficos, como $U$. appendiculatus, causam alterações mais amenas nos mecanismos de regulação dos processos fisiológicos da folha doente, pois necessitam, durante a sua fase de colonização e reprodução, da vitalidade da planta hospedeira para sua sobrevivência. Já, os patógenos hemibiotróficos, como $P$. griseola e $C$. lindemuthianum, são mais agressivos e têm um efeito mais drástico e destrutivo sobre os processos fisiológicos da planta hospedeira. 


\section{ANÁlise da fOtossíntese Pelas CuRVAS da ASSimilaÇÃo LÍQUida de $\mathrm{CO}_{2}$ PELA CONCENTRAÇÃO INTERCELULAR DE $\mathrm{CO}_{2}$ (A/Ci) EM FOLHAS DE FEIJOEIRO INFECTADAS COM FERRUGEM, MANCHA ANGULAR E ANTRACNOSE}

\subsection{Resumo}

A atividade fotossintética de folhas de feijoeiro, cv. Rosinha G-2 e cv. Carioca Comum, foi avaliada em folhas sadias e infectadas com ferrugem, mancha angular e antracnose. Para todas as doenças foi observada uma diminuição significativa na taxa fotossintética líquida da folha maior que a esperada pela simples redução da área foliar decorrente das lesões provocadas pelos patógenos. A amplitude deste decréscimo foi menor no caso da ferrugem, intermediária para a mancha angular e maior para a antracnose. A análise das curvas de resposta $A / C i$ permitiu a medição in vivo da contribuição dos fatores do estômato e do mesófilo sobre a fotossíntese da área verde remanescente das folhas doentes. Para a ferrugem, a diminuição da atividade fotossintética da área aparentemente sadia foi explicada somente pelo aumento da resistência à carboxilação, caracterizada pela redução da atividade da Rubisco, não havendo nenhum efeito sobre os estômatos. Também para a mancha angular, a resistência à carboxilação foi o principal componente responsável pela menor taxa de assimilação de $\mathrm{CO}_{2}$, mas certo aumento da limitação estomática da fotossíntese também foi observado. Quanto à antracnose, tanto a diminuição da atividade da Rubisco como o aumento da limitação estomática na área verde remanescente das folhas infectadas foram responsáveis pela redução da taxa de assimilação de $\mathrm{CO}_{2}$. Os mecanismos pelos quais estas doenças 
interferem com a atividade da Rubisco e com a regulação da abertura e fechamento dos estômatos são discutidos.

\subsection{Introdução}

Apesar da fundamental importância da fotossíntese como processo fisiológico determinante do potencial produtivo de uma cultura, relativamente pouco é conhecido sobre os efeitos de patógenos na fotossíntese de plantas doentes (Lucas, 1998).

Nas interações entre patógenos foliares e hospedeiros, geralmente, as taxas fotossintéticas líquida e bruta diminuem com o progresso da infeç̧ão em razão, principalmente, da redução da interceptação da radiação solar pela planta doente resultante da destruição da clorofila, necrose ou queda precoce dos tecidos fotossintetizantes da planta (Agrios, 1997; Goodman et al., 1986; Lucas, 1998). Contudo, não se pode ignorar a possibilidade de que existam efeitos nos tecidos foliares não infectados adjacentes, implicando numa mudança da eficiência fotossintética neste tecido verde remanescente como tem sido demonstrado, tanto para patógenos necrotróficos e hemibiotróficos (Bassanezi et al., 1997; Bastiaans, 1991; Bastiaans \& Roumen, 1993; Boote et al.; 1980; Bourgeois \& Boote, 1992; Ephrath et al.; 1989; Garry et al., 1998; Godoy et al., 1998; Godoy et al., 1999; Levy \& Leonard; 1990; Lopes, 1999; Martin, 1986; Shah et al., 1998; Shtienberg, 1992), como para patógenos biotróficos (Bassanezi, 1995; Lopes, 1999; McGrath \& Pennypacker, 1990; Rabbinge et al., 1985; Shtienberg, 1992).

A diminuição na taxa de assimilação de $\mathrm{CO}_{2}$ no tecido foliar verde remanescente de folhas doentes, geralmente, pode ser causada pelo aumento da resistência estomática e/ou pelo aumento da resistência à carboxilação. A resistência estomática, que é inversa da condutância estomática, representa o grau de fechamento dos estômatos. Uma menor condutância estomática leva ao aumento da resistência à entrada de $\mathrm{CO}_{2}$ do ambiente externo para o interior da folha. A redução da concentração intercelular de $\mathrm{CO}_{2}$ na folha (Ci), por sua vez, limita a atividade fotossintética (Farquar \& Sharkey, 1982). A 
resistência à carboxilação representa a resistência do mesófilo foliar à difusão de $\mathrm{CO}_{2}$, envolvendo o movimento deste através do citoplasma para os cloroplastos, o sítio da reação de carboxilação (Long, 1985). A reação de carboxilação, que fixa o $\mathrm{CO}_{2}$ em carboidratos, é catalisada pela enzima ribulose-1,5-bifosfato carboxilase/oxigenase (Rubisco) e, portanto, uma redução na atividade ou regeneração da Rubisco limita a assimilação de $\mathrm{CO}_{2}$ pela folha (Woodrow \& Berry, 1988).

$\mathrm{O}$ desenvolvimento da análise da curva de resposta $\mathrm{A} / \mathrm{C} i$ (taxa líquida de assimilação de $\mathrm{CO}_{2}$ versus concentração intercelular de $\mathrm{CO}_{2}$ ) por Farquar \& Sharkey (1982) tem permitido a medição in vivo dos fatores do estômato e do mesófilo sobre a fotossíntese das plantas, inclusive de plantas doentes (Hampton et al., 1990; Pennypacker et al., 1990).

Com o objetivo de determinar qual o mecanismo responsável pela redução da taxa de fotossintética do tecido verde remanescente de folhas de feijoeiro com ferrugem (Uromyces appendiculatus), mancha angular (Phaeoisariopsis griseola) ou antracnose (Colletotrichum lindemuthianum), foi realizada a análise de curvas $\mathrm{A} / \mathrm{C} i$ em folhas sadias e em folhas infectadas por estes três patógenos.

\subsection{Material e Métodos}

Dois experimentos foram realizados para as três doenças em duas cultivares de feijoeiro, Rosinha G-2 e Carioca Comum. Sementes pré-germinadas por $48 \mathrm{~h}$ foram transplantadas para vasos de alumínio (20 vasos para cada cultivar) com dois litros de mistura de terra argilosa, areia e esterco bovino curtido, na proporção $2: 2: 1$, em casa-devegetação. Onze dias após o plantio (dap), foi realizado um desbaste deixando apenas duas plantas bem homogêneas em cada vaso.

Aos 13 dap, foram feitas as inoculações com os três patógenos. Para cada patógeno foram utilizados cinco vasos de cada cultivar. Plantas de outros cinco vasos de cada cultivar foram mantidas sadias, pulverizadas apenas com água. Neste momento, a maior largura do folíolo central da primeira folha trifoliolada das cultivares Rosinha G-2 e 
Carioca Comum foi de, respectivamente, $5,0-7,0 \mathrm{~cm} \mathrm{e} \mathrm{4,0-6,0} \mathrm{cm,} \mathrm{no} \mathrm{primeiro}$ experimento, e 3,5-5,5 cm e 2,5-4,5 cm, no segundo experimento. As inoculações foram feitas separadamente para cada patógeno em ambas superficies da primeira folha trifoliolada, por meio da pulverização de uma suspensão de esporos em água + tween 20 (uma gota por $100 \mathrm{~mL}$ de suspensão) até o início do escorrimento. No primeiro experimento, foram utilizadas suspensões de esporos nas concentrações de $6,6 \times 10^{5} / \mathrm{mL}$, $8,7 \times 10^{5} / \mathrm{mL}$ e $7,5 \times 10^{4} / \mathrm{mL}$ e, no segundo experimento, de $9,8 \times 10^{5} / \mathrm{mL}, 4,8 \times 10^{5} / \mathrm{mL}$ e $1,9 \times 10^{5} / \mathrm{mL}$ para C. lindemuthianum, P. griseola e U. appendiculatus, respectivamente. Imediatamente após a inoculação, os vasos foram cobertos por um saco plástico previamente umedecido e colocados em câmaras de crescimento no escuro por 24 horas a $19^{\circ} \mathrm{C}$, no caso de $C$. lindemuthiamum e U. appendiculatus, e por 30 horas a $24^{\circ} \mathrm{C}$, no caso de $P$. griseola. Logo após este período de incubação, foram retirados os sacos plásticos, feito um desponte acima das folhas inoculadas, retirados os brotos axilares das plantas, adubadas as plantas com solução de $\mathrm{NH}_{4} \mathrm{NO}_{3}+\mathrm{KCl}$ e os vasos colocados de volta nas câmaras de crescimento a $22{ }^{\circ} \mathrm{C}$ sob fotoperíodo de 14 horas de luz $\left( \pm 200 \mu \mathrm{mol} \mathrm{m}^{-2} \mathrm{~s}^{-1}\right.$ PAR $)$ e 10 horas de escuro.

As avaliações foram feitas aos 5-7 dias após a inoculação (dai) para a antracnose (estádio de nervuras pardo-avermelhadas, início de murcha e secamento do tecido foliar), 8-9 dai para a mancha angular (estádio de lesões necróticas angulares com 3-4 $\mathrm{mm}^{2}$ delimitadas pelas nervuras) e 10-11 dai para a ferrugem (estádio com todas pústulas esporulando com 1,7 a $3,1 \mathrm{~mm}^{2}$ de tamanho).

As medições da taxa de assimilação líquida de $\mathrm{CO}_{2}(A)$, condutância estomática (gs) e concentração intercelular de $\mathrm{CO}_{2}(\mathrm{Ci})$ foram realizadas no folíolo central da primeira folha trifoliolada com o Portable Photosynthesis System LI-6400 (Licor ${ }^{\circledR}$ ) mantendo-se uma intensidade de irradiação de $400 \mu \mathrm{mol} \mathrm{m}^{-2} \mathrm{~s}^{-1}$ PAR (Apêndice 1), temperatura da folha na câmara de análise a $25{ }^{\circ} \mathrm{C}$ e variando-se a concentração de $\mathrm{CO}_{2}$ do ar entrando na câmara $(C e)$. As $C e$ utilizadas foram: $60,80,110,150,230,350,500$ e 700 ppm, iniciando da menor para a maior concentração. A folha permaneceu em cada 
concentração por um tempo mínimo de 2 minutos e máximo de 4 minutos até que as leituras atingissem um coeficiente de variação menor ou igual a $0,5 \%$.

Após a avaliação das trocas gasosas, na região que estava dentro da câmara de análise, foi avaliada a severidade de doença (proporção da área foliar com sintomas). Considerando que os tecidos necróticos ou secos devido às lesões não realizam fotossíntese e seus estômatos não são ativos, os valores de $A$ e gs foram recalculados em função da área foliar verde remanescente, dividindo-os pelo fator $f=(1$ - severidade $)$.

Com os dados da $A$ da área foliar verde remanescente e da respectiva $C i$ calculada foram obtidas as curvas $\mathrm{A} / \mathrm{Ci}$ para cada folha avaliada conforme ilustrado na Figura 01. Foi realizada uma regressão linear com os quatro primeiros pontos da curva e obtida a atividade da enzima Rubisco $\left(A R u b, \mathrm{~mol} \mathrm{~m}^{-2} \mathrm{~s}^{-1}\right)$ por meio do valor do coeficiente angular da reta (Farquar \& Sharkey, 1982). A limitação estomática da fotossíntese ( $L E F, \%)$ foi obtida pela eq. (1) de Farquar \& Sharkey (1982) adaptada por Pennypacker et al. (1990):

$$
L E F=\left[\left(A C i_{350}-A C e_{350}\right) / A C i_{350}\right] \times 100
$$

na qual $A C e_{350}$ é a taxa fotossintética líquida quando a concentração de $\mathrm{CO}_{2}$ do ar que entra na câmara é de $350 \mathrm{ppm} \mathrm{e} A C i_{350}$ é a taxa fotossintética líquida quando a concentração de $\mathrm{CO}_{2}$ intercelular na folha é de $350 \mathrm{ppm}$. O valor de $A C i_{350}$ foi estimado pela equação obtida pelo ajuste do modelo monomolecular aos dados da curva $\mathrm{A} / \mathrm{C} i$.

O delineamento experimental foi fatorial $2 \times 2$ (Cultivares: Rosinha G-2 e Carioca Comum x Doença: Sadio e Doente), inteiramente ao acaso, com cinco repetições para cada tratamento. A unidade experimental foi constituída por duas folhas de plantas diferentes em um mesmo vaso, das quais foram calculados os valores médios de cada variável. A análise de variância foi realizada para cada experimento separadamente por não serem os experimentos repetidos da mesma forma, com iguais concentrações de inóculo e mesmo tamanho dos folíolos inoculados. 


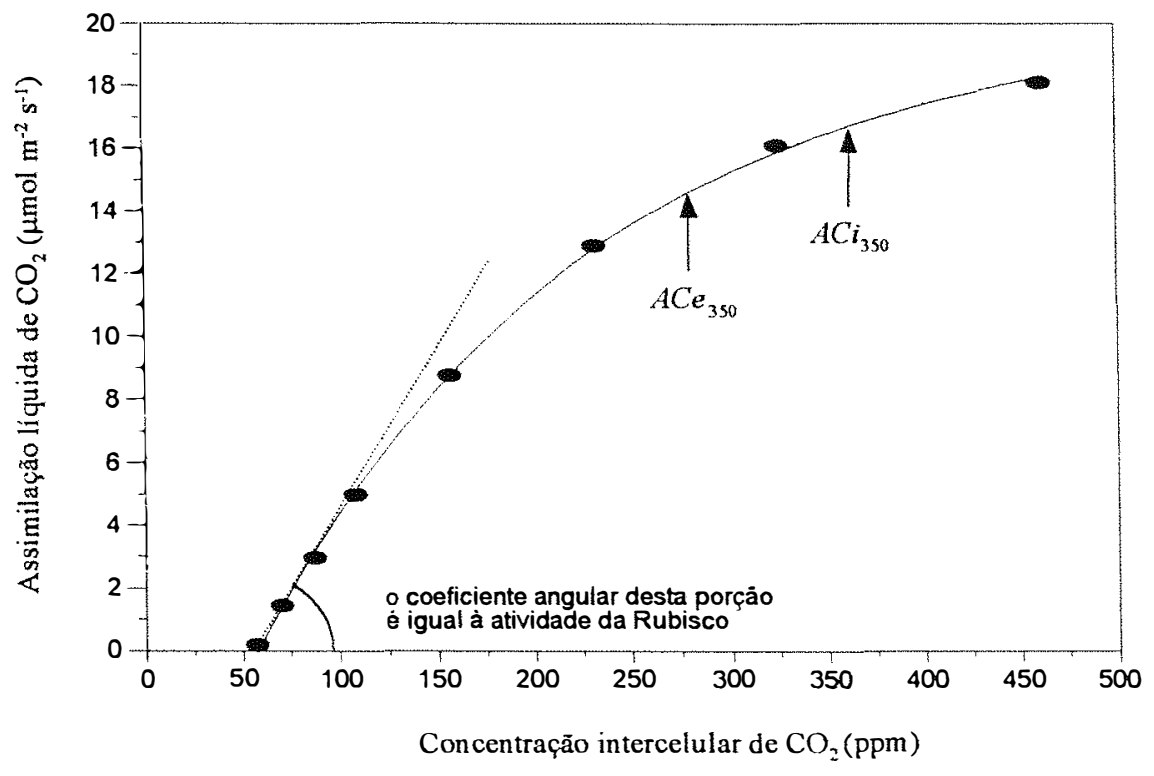

Figura 01. Exemplo de uma curva de resposta $A / C i$ mostrando a porção da curva usada para determinar a atividade da Rubisco e os pontos para determinar a limitação estomática da fotossintese.

\subsection{Resultados}

\subsubsection{Ferrugem}

No primeiro experimento, os níveis de severidade de ferrugem foram respectivamente 6,4 e 4,8 \% para cv. Rosinha G-2 e cv. Carioca Comum (Figura 02) e não foram detectadas diferenças significativas $(P<0,01)$ entre a área verde remanescente das folhas doentes e das folhas sadias em todas as variáveis avaliadas (Tabela 01). 
Contudo, no segundo experimento, com níveis de severidade média em $28,8 \%$, os resultados revelaram que a área verde remanescente das folhas infectadas com $U$. appendiculatus tiveram valores significativamente menores $(P<0,01)$ de $A C e_{350}$ e $A R u b$ quando comparadas às folhas sadias não inoculadas (Tabela 01). A redução de $30 \%$ na média observada na $A C e_{350}$ da área verde remanescente das folhas doentes no segundo experimento pode ser diretamente relacionada com a redução na $A R u b$ ( $27 \%$ na média) deste tecido uma vez que para as variáveis $g s_{350}$ e $L E F$ não houve diferença significativa entre as folhas sadias e a área verde remanescente das folhas doentes em ambas cultivares (Tabela 01 e Figura 02).

Tabela 01. Efeitos principais dos dados da análise de variância no efeito de Uromyces appendiculatus nas cultivares de feijoeiro nos dois experimentos (médias de 10 observações).

\begin{tabular}{|c|c|c|c|c|c|}
\hline Efeitos principais & $\begin{array}{c}\text { Severidade } \\
(\%) \\
\end{array}$ & $\begin{array}{c}A C e_{350} \\
\left(\mu \mathrm{molm}^{-2} \mathrm{~s}^{-1}\right)\end{array}$ & $\begin{array}{c}A R u b \\
\left(\mathrm{~mol} \mathrm{~m}^{-2} \mathrm{~s}^{-1}\right)\end{array}$ & $\begin{array}{c}g s_{350} \\
\left(\mathrm{~mol} \mathrm{~m}^{-2} \mathrm{~s}^{-1}\right)\end{array}$ & $\begin{array}{l}L E F \\
(\%)\end{array}$ \\
\hline \multicolumn{6}{|l|}{$\begin{array}{l}\text { Experimento } 1 \\
\text { Cultivar }\end{array}$} \\
\hline Rosinha G-2 & 3,2 & 10,69 & 0,086 & 0,179 & 26,2 \\
\hline Carioca Comum & 2,4 & $11,43^{*}$ & 0,090 & $0,214^{*}$ & $20,9 *$ \\
\hline \multicolumn{6}{|l|}{ Doença } \\
\hline Sadio & 0,0 & 11,17 & 0,091 & 0,192 & 23,5 \\
\hline Doente & $5,6 *$ & 10,95 & 0,085 & 0,202 & 23,6 \\
\hline \multicolumn{6}{|l|}{$\begin{array}{l}\text { Experimento } 2 \\
\text { Cultivar }\end{array}$} \\
\hline Rosinha G-2 & 15,1 & 9,25 & 0,074 & 0,182 & 23,3 \\
\hline Carioca Comum & 13,8 & $10,66^{*}$ & 0,082 & $0,244^{*}$ & $18,3^{*}$ \\
\hline \multicolumn{6}{|l|}{ Doença } \\
\hline Sadio & 0,0 & 11,71 & 0,090 & 0,219 & 21,5 \\
\hline Doente & $28,8 *$ & $8,20 *$ & $0,066 *$ & 0,207 & 20,1 \\
\hline
\end{tabular}



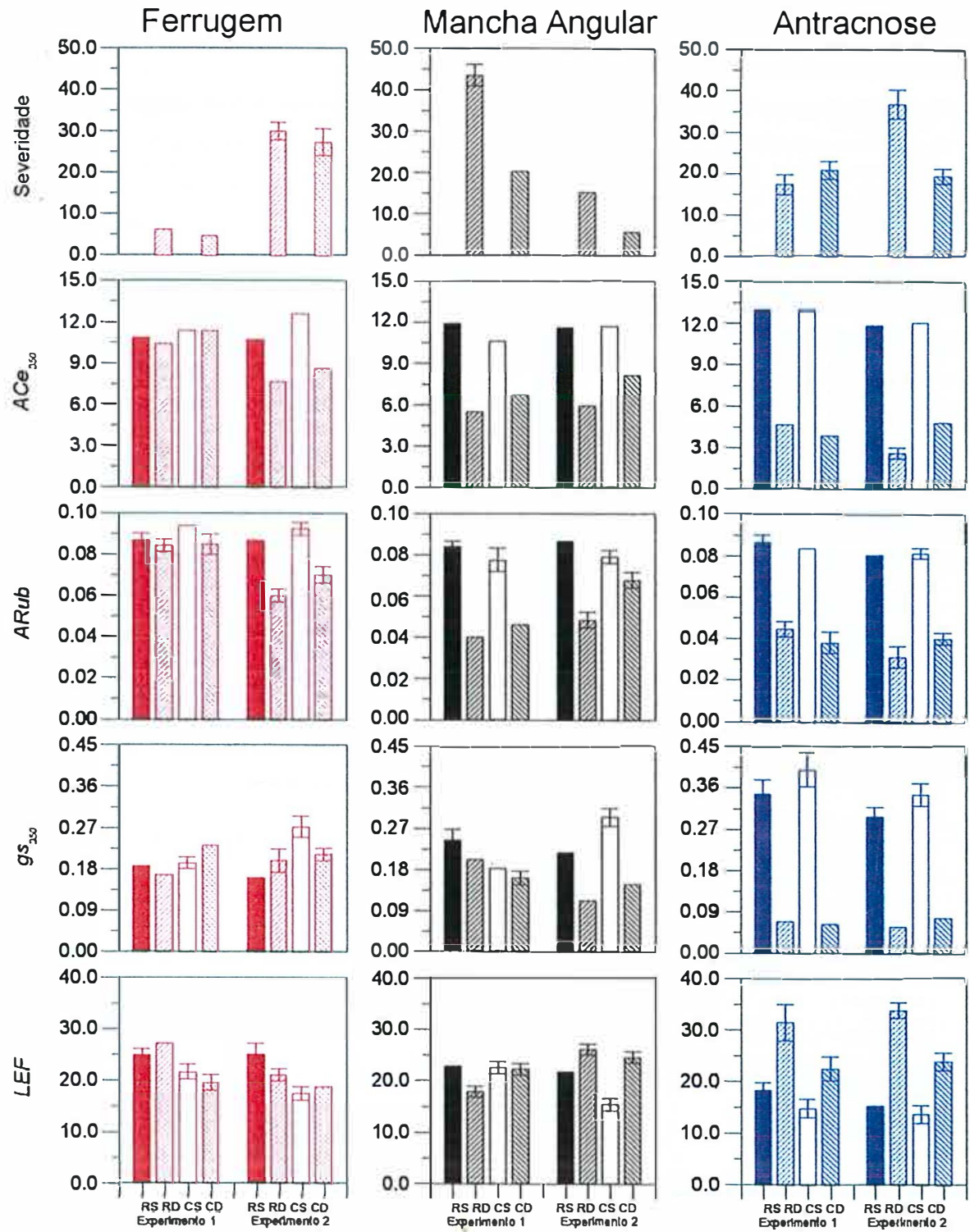

Figura 02. Severidade (\%) na região avaliada, $A C e_{350}\left(\mu \mathrm{mol} \mathrm{m} \mathrm{s}^{-1}\right), A R u b\left(\mathrm{~mol} \mathrm{~m}^{-2} \mathrm{~s}^{-1}\right)$, $g_{s_{350}}\left(\mathrm{~mol} \mathrm{~m}^{-2} \mathrm{~s}^{-1}\right)$ e $\operatorname{LEF}(\%)$ na área verde remanescente das folhas da $\mathrm{cv}$. Rosinha G-2 sadia (RS) e doente (RD) e Carioca Comum sadia (CS) e doente (CD) nos dois experimentos com ferrugem, mancha angular e antracnose (média \pm erro padrão de cinco observações). 


\subsubsection{Mancha Angular}

Nos dois experimentos realizados a cv. Carioca Comum mostrou-se significativamente $(P<0,01)$ mais resistente à mancha angular que a cv. Rosinha G-2, apresentando menores valores de severidade. Como consequêencia, os efeitos nas variáveis avaliadas foram mais marcantes na cv. Rosinha G-2 (Figura 02).

A área verde remanescente das folhas infectadas com $P$. griseola tiveram valores significativamente menores $(P<0,01)$ de $A C e_{350}$ e $A R u b$ quando comparadas às folhas sadias não inoculadas, em ambos experimentos (Tabela 02),. Quanto maior a severidade de doença, maior foi o efeito observado deste patógeno na região aparentemente não infectada da folha doente. No primeiro experimento, com severidade média de $31,8 \%$, as reduções na $A C e_{350}$ e $A R u b$ foram, respectivamente, de 46 e $47 \%$, enquanto que no segundo, com severidade média de 10,4\%, foram de 40 e $30 \%$ (Tabela 02 e Figura 02).

Tabela 02. Efeitos principais dos dados da análise de variância no efeito de Phaeoisariopsis griseola nas cultivares de feijoeiro nos dois experimentos (médias de 10 observações).

\begin{tabular}{|c|c|c|c|c|c|}
\hline Efeitos principais & $\begin{array}{c}\text { Severidade } \\
(\%) \\
\end{array}$ & $\begin{array}{c}A C e_{350} \\
\left(\mu \mathrm{molm}^{-2} \mathrm{~s}^{-1}\right)\end{array}$ & $\begin{array}{c}A R u b \\
\left(\mathrm{~mol} \mathrm{~m}^{-2} \mathrm{~s}^{-1}\right) \\
\end{array}$ & $\begin{array}{c}g s_{350} \\
\left(\mathrm{~mol} \mathrm{~m}^{-2} \mathrm{~s}^{-1}\right) \\
\end{array}$ & $\begin{array}{r}L E F \\
(\%) \\
\end{array}$ \\
\hline \multicolumn{6}{|l|}{ Experimento 1} \\
\hline \multicolumn{6}{|l|}{ Cultivar } \\
\hline Rosinha G-2 & 21,8 & 8,69 & 0,062 & 0,223 & 20,3 \\
\hline Carioca Comum & $10,1 *$ & 8,66 & 0,062 & $0,172 *$ & 22,4 \\
\hline \multicolumn{6}{|l|}{ Doença } \\
\hline Sadio & 0,0 & 11,25 & 0,081 & 0,214 & 22,7 \\
\hline Doente & $31,8 *$ & $6,10 *$ & $0,043 *$ & 0,181 & 20,1 \\
\hline \multicolumn{6}{|l|}{ Experimento 2} \\
\hline \multicolumn{6}{|l|}{ Cultivar } \\
\hline Rosinha G-2 & 7,6 & 8,77 & 0,067 & 0,165 & 24,0 \\
\hline Carioca Comum & $2,8 *$ & $9,92 *$ & 0,073 & $0,221 *$ & $20,0 *$ \\
\hline \multicolumn{6}{|l|}{ Doença } \\
\hline Sadio & 0,0 & 11,65 & 0,083 & 0,256 & 18,6 \\
\hline Doente & $10,4 *$ & $7,04 *$ & $0,058 *$ & $0,130 *$ & $25,4 *$ \\
\hline
\end{tabular}


Quanto à $g s_{350}$ e $L E F$ da área verde remanescente das folhas doentes, os resultados mostraram menores $g s_{350}$ e maiores $L E F$ em relação às folhas não inoculadas somente no segundo experimento. Nas folhas com severidade média maior de $20 \%$ (Exp. 1) não houve diferença significativa $(P<0,01)$ entre a $g s_{350}$ e $L E F$ da área verde remanescente das folhas doentes e das folhas sadias, mas nas folhas com severidade média menor de $20 \%$ (Exp. 2), houve uma redução de $49 \%$ e um aumento de $37 \%$, ambos significativos, na $g s_{350}$ e $L E F$, respectivamente (Tabela 02 e Figura 02).

A redução da $A C e_{350}$ das áreas verdes remanescentes deve ser decorrente da menor $A R u b$ e da maior $L E F$ nas folhas com baixa severidade de mancha angular, enquanto que em folhas com severidade mais alta a redução da $A C e_{350}$ está principalmente relacionada à menor $A R u b$.

\subsubsection{Antracnose}

Os resultados, tanto no primeiro como no segundo experimento, revelaram que as áreas verdes remanescentes das folhas infectadas com $C$. lindemuthianum tiveram valores significativamente menores $(P<0,01)$ de $A C e_{350}, A R u b$ e $g s_{350}$ e maior valor de $L E F$ quando comparadas às folhas sadias não inoculadas, independentemente da cultivar (Tabela 03 e Figura 02).

Todos os efeitos de redução ou aumento nas variáveis avaliadas foram maiores quanto maior a severidade da antracnose (Figura 02). Por exemplo, no Exp. 2, a cv. Rosinha G-2 mostrou severidade média de $36,9 \%$, reduções da $A C e_{350}, A R u b$ e $g s_{350}$ de 78, 60 e $80 \%$, respectivamente, e aumento da $L E F$ de $121 \%$. Já a cv. Carioca, no mesmo experimento, teve severidade média de $19,6 \%$, reduções da $A C e_{350}, A R u b$ e $g s_{350}$ de 60, 50 e $78 \%$, respectivamente, e aumento da $L E F$ de $74 \%$.

No caso da antracnose do feijoeiro, a redução observada na $A C e_{350}$ da área aparentemente sadia das folhas doentes ( $68 \%$ na média) foi diretamente relacionada com a diminuição na $A R u b$ (53\% na média) e na $C i$, causada pela redução na $g S_{350}(81 \%$ na média) e aumento na $L E F$ ( $80 \%$ na média) neste tecido foliar. 
Tabela 03. Efeitos principais dos dados da análise de variância no efeito de Colletotrichum lindemuthianum nas cultivares de feijoeiro nos dois experimentos (médias de 10 observações).

\begin{tabular}{|c|c|c|c|c|c|}
\hline Efeitos principais & $\begin{array}{c}\text { Severidade } \\
(\%)\end{array}$ & $\begin{array}{c}A C e_{350} \\
\left(\mu \mathrm{molm}^{-2} \mathrm{~s}^{-1}\right)\end{array}$ & $\begin{array}{c}A R u b \\
\left(\mathrm{~mol} \mathrm{~m}^{-2} \mathrm{~s}^{-1}\right)\end{array}$ & $\begin{array}{c}g s_{350} \\
\left(\mathrm{~mol} \mathrm{~m}^{-2} \mathrm{~s}^{-1}\right)\end{array}$ & $\begin{array}{c}L E F \\
(\%)\end{array}$ \\
\hline \multicolumn{6}{|l|}{$\begin{array}{l}\text { Experimento } 1 \\
\text { Cultivar }\end{array}$} \\
\hline Rosinha G-2 & 8,8 & 8,91 & 0,066 & 0,210 & 25,0 \\
\hline Carioca Comum & 10,5 & 8,49 & 0,061 & 0,233 & 18,8 \\
\hline \multicolumn{6}{|l|}{ Doença } \\
\hline Sadio & 0,0 & 13,07 & 0,085 & 0,375 & 16,7 \\
\hline Doente & $19,3 *$ & $4,33^{*}$ & $0,042 *$ & $0,068^{*}$ & $27,1 *$ \\
\hline \multicolumn{6}{|l|}{$\begin{array}{l}\text { Experimento } 2 \\
\text { Cultivar }\end{array}$} \\
\hline Rosinha G-2 & 18,5 & 7,30 & 0,050 & 0,179 & 24,6 \\
\hline Carioca Comum & $9,8 *$ & $8,49 *$ & 0,058 & 0,213 & $18,9 *$ \\
\hline \multicolumn{6}{|l|}{ Doença } \\
\hline Sadio & 0,0 & 12,01 & 0,082 & 0,323 & 14,6 \\
\hline Doente & $28,3 *$ & $3,78 *$ & $0,027^{*}$ & $0,069 *$ & $29,0 *$ \\
\hline
\end{tabular}

\subsubsection{Comparação das cultivares de feijoeiro}

Não foi observada diferença significativa $(P<0,01)$ entre as severidades de ferrugem nas duas cultivares, mas a cv. Rosinha G-2 apresentou severidades de doença maiores ou iguais que a cv. Carioca Comum, tanto para a mancha angular (43,5 contra $20,1 \%$ no Exp. 1 e 15,2 contra 5,5\% no Exp. 2), como para a antracnose (17,6 contra $21,0 \%$ no Exp. 1 e 36,9 contra $19,6 \%$ no Exp. 2), indicando sua maior suscetibilidade à estas duas doenças (Figura 02).

As variáveis fisiológicas avaliadas $\left(A C e_{350}, g s_{350}, A R u b\right.$ e $\left.L E F\right)$ das folhas sadias de ambas cultivares praticamente não diferiram entre si (Figura 02). 


\subsection{Discussão}

As diminuições da taxa fotossintética líquida das folhas de feijoeiro infectadas com ferrugem, mancha angular ou antracnose não foram completamente explicadas pela redução da área foliar devido aos sintomas das doenças, indicando que a área verde remanescente destas folhas infectadas teve sua taxa fotossintética também reduzida como observado no presente trabalho. Observações neste sentido já haviam sido feitas em estudos anteriores para a ferrugem (Bassanezi, 1995; Lopes, 1999), mancha angular (Bassanezi, 1995) e antracnose (Bassanezi et al., 1997; Lopes, 1999) do feijoeiro. A diminuição da eficiência fotossintética nas regiões aparentemente sadias das folhas doentes foi menor para a ferrugem ( $27 \%$ na média), intermediária para a mancha angular (43\% na média) e maior para a antracnose (68\% na média), indicando possíveis diferenças entre as três doenças nos mecanismos de inibição da fotossíntese das folhas infectadas.

No caso da ferrugem do feijoeiro, causada por um patógeno biotrófico, um efeito mais ameno resultante de uma íntima relação entre o patógeno e o tecido colonizado pode ser esperado. Como observado neste trabalho, a falta de qualquer efeito do patógeno sobre a $L E F$ indicou que a redução da taxa de assimilação de $\mathrm{CO}_{2}$ na região verde remanescente das folhas doentes não foi causada pela menor disponibilidade de $\mathrm{CO}_{2}$ resultante da menor $g s$. A reduzida $A R \boldsymbol{u} b$ detectada nas folhas infectadas foi, portanto, o principal fator responsável pela menor taxa fotossintética na área verde remanescente das folhas com ferrugem do feijoeiro, limitando a quantidade de $\mathrm{CO}_{2}$ fixada.

A influência dos patógenos biotróficos no mecanismo de regulação dos estômatos, resistência da camada laminar e resistência do transporte de $\mathrm{CO}_{2}$ no mesófilo parece ser pouca ou nenhuma e tem levado alguns pesquisadores a concluir que o aumento da resistência à carboxilação, causado por alterações metabólicas nos cloroplastos ou mudanças na quantidade do maquinário fotossintético, seja o principal responsável pela redução da taxa fotossintética em folhas com ferrugem (Owera et al., 
1981) ou oídio (Gordon \& Duniway, 1982; Mignucci \& Boyer, 1979; Rabbinge et al., 1985). A diminuição da atividade da RuBP carboxilase por unidade de área tem sido observada em folhas de outras culturas com oídio (Scholes et al., 1994; Walters \& Ayres, 1984) e com ferrugem (Roberts \& Walters, 1988). No caso da ferrugem do feijoeiro, baseado nos dados de Stangarlin (1999), também foi observada por análise bioquímica a redução na atividade inicial e total da Rubisco nas regiões da folha entre as pústulas.

$\mathrm{O}$ acúmulo de amido ao redor dos sítios de infecção tem sido observado em folhas de feijoeiro com U. appendiculatus (Sziráki et al., 1984; Wagner \& Boyle, 1995; Wang, 1961). O conteúdo de açúcares redutores, sacarose e amido aumenta nos tecidos infectados no estádio de fleck e depois diminui durante a esporulação do fungo (Inman, 1962; Wagner \& Boyle, 1995) estando diretamente relacionado com o aumento da atividade da invertase ácida neste período (Wagner \& Boyle, 1995). Segundo Moerschbacher et al. (1994), para a ferrugem do colmo do trigo, a invertase do fungo hidrolizaria a sacarose em hexoses que não podem ser exportadas do tecido infectado da folha, mas podem ser absorvidas pelo fungo. Adicionalmente, criaria-se um dreno dentro da folha infectada redirecionando o fluxo de assimilados para o fungo e acumulando hexoses que por realimentação negativa inibiriam a $A R u b$ e, por conseqüência, a fixação de $\mathrm{CO}_{2}$ em mais carboidratos.

Com relação aos patógenos hemibiotróficos ou necrotróficos, tem sido observada a diminuição da gs e o aumento da resistência do mesófilo à difusão de $\mathrm{CO}_{2}$ com a evolução dos sintomas, como no caso de folhas de cevada infectadas com Rynchosporium secalis (Martin, 1986).

Quanto à mancha angular, a menor eficiência fotossintética da área verde remanescente parece estar associada também à redução da $A R u b$ nesta região. Estes resultados corroboram os de Stangarlin (1999) que também observou menores atividades inicial e total da Rubisco em folhas de feijoeiro infectadas com $P$. griseola por meio da quantificação direta in vivo e in vitro. Mouly et al. (1988) e Kombrink \& Hahlbrock (1990) verificaram que as infecções por Sclerotinia sclerotiorum em girassol e Phytophthora infestans em batata, respectivamente, ocasionaram a redução nos níveis de 
RNAm que codificam as subunidades pequenas da Rubisco e, conseqüentemente, a redução nos níveis da enzima nas áreas verdes remanescentes das folhas atacadas.

Adicionalmente, um pequeno efeito sobre a abertura dos estômatos nesta região entre as lesões poderia ser sugerido como melhor observado no segundo experimento, no qual a menor abertura dos estômatos, expressa pela diminuição da $g s$, limitou a fotossintese pela menor quantidade de $\mathrm{CO}_{2}$ disponivel no interior da folha. A senescência e desfolha precoce de folhas de feijoeiro com sintomas de mancha angular são comumente relatadas na literatura (Ferraz, 1980; Godoy, 1995; Mora Brenes, 1983). Apesar de não terem sido realizados estudos específicos com a mancha angular, sabe-se que o acúmulo de dois hormônios, ácido abscísico e etileno, nos tecidos infectados por alguns fungos fitopatogênicos leva aos processos de senescência (clorose) e abscisão foliar (Pascholati, 1995). Além disso, o ácido abscísico também pode estar envolvido no fechamento dos estômatos, resultando na redução da taxa fotossintética totalmente pelo aumento da $L E F$, uma vez que ele não afeta as reações de carboxilação (Farquar \& Sharkey, 1982).

No caso da antracnose parece evidente a participação dos dois mecanismos na redução da atividade fotossintética da área verde remanescente das folhas doentes. A redução da $g s$ e o aumento da $L E F$ observados são conseqüências do bloqueio e ruptura dos vasos condutores nas folhas infectadas pelo patógeno, causando um déficit hídrico no restante da folha, que por sua vez levaria ao fechamento dos estômatos para regulação da taxa de transpiração e conservação de água na folha. O fechamento dos estômatos seria responsável pela redução da $\mathrm{C} i \mathrm{e}$, subseqüente redução da taxa fotossintética.

Existem, porém, algumas evidências que, embora a condutância estomática fosse reduzida em plantas infectadas com fitopatógenos que colonizam os vasos condutores, a redução na fotossintese nem sempre é devido ao estresse hídrico induzido pelo patógeno. A redução na fotossintese de plantas de tomate infectadas com Fusarium oxysporum f.sp. lycopersici raça 1 foi causada em parte pelo aumento da resistência estomática e em parte pelo grande aumento na resistência do mesófilo que ocorreram antes da deteç̧ão do déficit hídrico na folha. $\mathrm{O}$ aumento da resistência do mesófilo, neste caso, foi associado 
com as reduções na respiração e fotorrespiração, mas não com um decréscimo na atividade da RuBP carboxilase (Duniway \& Slatyer, 1971). Curvas de resposta $A / C i$ têm mostrado, porém, que algumas murchas afetam diretamente a eficiência da carboxilação promovida pela enzima Rubisco (Hampton et al., 1990; Pennypacker et al., 1990). Hampton et al. (1990) concluíram que a menor capacidade fotossintética das folhas de algodoeiro resultante da infecção por Verticillium dahliae foi produto de dois mecanismos distintos de patogenicidade. Inicialmente, antes do aparecimento dos sintomas visíveis, a redução da fotossíntese foi dada por processos não estomáticos não diretamente mediados pelo estresse de déficit hídrico. Ao contrário, folhas com sintomas exibiram uma fotossíntese reduzida pela combinação dos efeitos de clorose, estresse hídrico e fechamento dos estômatos. Pennypacker et al. (1990), trabalhando com Verticillium albo-atrum em alfafa, indicaram que a redução na quantidade e atividade da enzima carboxilase (Rubisco) foi o fator responsável pela redução na fotossíntese líquida de plantas infectadas ao invés da redução da concentração intercelular de $\mathrm{CO}_{2}$ causada pela menor $g s$ da folha. 


\section{EFICIÊNCIA FOTOSSINTÉTICA DA ÁREA VERDE REMANESCENTE DE FOLHAS DE FEIJOEIRO COM FERRUGEM, MANCHA ANGULAR OU ANTRACNOSE}

\subsection{Resumo}

O efeito da ferrugem, mancha angular e antracnose do feijoeiro na taxa fotossintética líquida de folhas de Phaseolus vulgaris foi avaliado em diferentes situações, incluindo diferentes épocas de avaliação após a infecção e estádios fenológicos da cultura, temperaturas de desenvolvimento da doença e duas cultivares de feijoeiro em condições de ambiente controlado e de campo. O efeito de cada doença foi explicado quantitativamente pelo parâmetro $\beta$ do modelo proposto por Bastiaans (1991). Valores de $\beta$ ao redor de 2,4 e 8 , obtidos respectivamente para a ferrugem, mancha angular e antracnose, indicaram que estas três doenças causam em menor ou maior intensidade uma redução na eficiência fotossintética não apenas no tecido lesionado, mas também em parte do tecido verde remanescente das folhas infectadas. Diferenças entre os valores de $\beta$ obtidos para cada doença e a amplitude da redução da eficiência de uso da radiação pela folha estão associadas aos mecanismos pelos quais os patógenos se relacionam com o hospedeiro, atuando no processo fotossintético da folha infectada, e aos diferentes sintomas provocados pelas doenças. $O$ parâmetro $\beta$ estimado para cada doença mostrou ser constante sob as diversas situações estudadas e a sua incorporação no cálculo de absorção da área foliar sadia ( $H A A)$ e duração da área foliar sadia $(H A D)$ ou em modelos similares para a previsão da produção ou dos danos na cultura do feijoeiro atacada por estas doenças é sugerida. 


\subsection{Introdução}

A quantidade de radiação solar interceptada pela área foliar verde (RI, radiation interception) e a eficiência do uso desta radiação (RUE, radiation use efficiency) são os fatores determinantes da produção de matéria seca e, conseqüentemente, da produção de grãos pela planta (Monteith, 1977; Monteith, 1981), mostrando ser a fotossíntese um processo fisiológico chave para o entendimento do potencial produtivo de uma cultura. A despeito de sua fundamental importância, comparativamente pouco é conhecido sobre os efeitos de patógenos na fotossíntese. Das poucas generalizações que podem ser feitas com respeito à maneira pela qual os patógenos afetam a fotossíntese, pode-se dizer que na maioria das interações patógeno/hospedeiro, as taxas fotossintéticas líquida e bruta diminuem com o progresso da infecção (Lucas, 1998).

Parece óbvio que a redução da $R I$ pela planta doente devido à redução dos tecidos fotossintetizantes da planta por necrose ou queda precoce é o principal resultado da invasão do patógeno na redução da capacidade fotossintética da planta e na redução da produção das culturas (Haverkort \& Bicamumpaka, 1986; Madeira et al., 1988; Waggoner \& Berger, 1987). Contudo, não se pode ignorar a possibilidade de que existam efeitos nos tecidos foliares adjacentes não infectados, implicando numa mudança da $R U E$ neste tecido remanescente (Johnson, 1987).

Como relatado em alguns trabalhos, há um efeito na eficiência fotossintética nas áreas não infectadas de folhas doentes, em folhas assintomáticas de plantas doentes e em áreas infectadas antes de ocorrer a morte celular e a necrose dos tecidos, resultando numa menor RUE (Bassanezi, 1995; Bassanezi et al., 1997; Bastiaans, 1991 e 1993; Bastiaans \& Roumen, 1993; Boote et al., 1980; Bourgois \& Boote, 1992; Elings et al., 1999; Ephrath et al.; 1989; Garry et al., 1998; Godoy et al., 1998; Godoy et al., 1999; Goodwin, 1992; Levy \& Leonard, 1990; Lopes, 1999; Martin, 1986; McGrath \& Pennypacker, 1990; Rabbinge et al., 1985; Shtienberg, 1992; van der Werf et al., 1990).

Bastiaans (1991) propõe uma generalização interessante e útil que permite a classificação de patógenos de acordo com sua habilidade em afetar a $R U E$ de seus 
hospedeiros. O conceito é baseado na relação entre lesão visual ( $x$, proporção de área foliar visualmente doente) e lesão virtual ( $y$, proporção de área foliar onde a atividade fotossintética é nula), relação que é dada pelo parâmetro $\beta$ determinado experimentalmente pela determinação da fotossíntese de uma folha com severidade de doença $x$ e da fotossintese de uma folha sadia.

Diante do exposto, o objetivo deste trabalho foi analisar o efeito de três patógenos foliares (Uromyces appendiculatus, Colletotrichum lindemuthianum e Phaeoisariopsis griseola) na eficiência fotossintética de folhas de feijoeiro, estabelecendo relações entre a severidade de cada doença e o seu efeito na atividade fotossintética das folhas de feijoeiro doentes com a aplicação do conceito proposto por Bastiaans (1991). Foram verificadas as influências de diferentes épocas de avaliação após a infecção, temperaturas de desenvolvimento da doença e cultivares na determinação desta relação entre severidade de doença e redução da taxa fotossintética líquida de folhas doentes de feijoeiro por meio de experimentos em condições controladas. A fim de confirmar os dados dos experimentos em condições controladas, experimentos em condição de campo determinaram a influência de avaliações em diferentes estádios fenológicos da cultura nas duas cultivares na estimativa do valor de $\beta$ para cada doença.

\subsection{Material e Métodos}

\subsubsection{Experimentos em câmaras de crescimento}

Experimentos em câmara de crescimento, com condições de temperatura e fotoperíodo controladas, foram realizados para a determinação da relação entre a taxa fotossintética de folhas de feijoeiro e a severidade de ferrugem (experimentos F1 a F4), mancha angular (experimentos M1 a M4) e antracnose (experimentos A1 a A6) sob diferentes temperaturas e em duas cultivares de feijoeiro. Os experimentos F1, F2, M1, $\mathrm{M} 2, \mathrm{~A} 1, \mathrm{~A} 2$ e $\mathrm{A} 3$ foram conduzidos com a cr. Rosinha G-2, enquanto que os demais experimentos foram conduzidos com a cv. Carioca Comum. 
Sementes de feijoeiro das cultivares utilizadas foram pré-germinadas em placas de Petri por 48 horas no escuro ao redor de $25^{\circ} \mathrm{C}$. Em cada placa foram colocadas 10 sementes sobre duas folhas de papel de filtro embebidas em água destilada. Após a germinação, as plântulas foram transplantadas para vasos de alumínio com dois litros de mistura de terra argilosa, areia e esterco de curral, na proporção de 2:2:1, e foram mantidas em condição de casa-de-vegetação até a inoculação. Em cada vaso foram transplantadas quatro plântulas e após 7 a 11 dias foi feito um desbaste deixando duas plantas por vaso. Todo este procedimento foi adotado para obter plantas bem homogêneas em relação à idade e tamanho de folhas.

Em todos experimentos, os vasos, antes da inoculação das plantas, foram divididos em quatro grupos (quatro níveis de inóculo) de cinco vasos (cinco repetições) com duas plantas cada um. Diferentes niveis de concentração de esporos nas suspensões foram utilizados para a inoculação das plantas em cada grupo, possibilitando diferentes níveis de severidade de doença nas folhas inoculadas.

Nos experimentos com a ferrugem, aos 13 dias após o transplantio (dat), a segunda folha trifoliolada foi inoculada quando o foliolo central da mesma tinha de 2-4 $\mathrm{cm}$ de largura máxima. As concentrações utilizadas no ensaio F1, F2, F3 e F4 foram, respectivamente, $0,0,9 \times 10^{4}, 4,1 \times 10^{4}$ e $1,2 \times 10^{5} ; 0,1,5 \times 10^{4}, 6,9 \times 10^{4}$ e $2,0 \times 10^{5} ; 0$, $2,1 \times 10^{4}, 6,9 \times 10^{4}$ e $1,3 \times 10^{5} ; 0,1,9 \times 10^{4}, 4,9 \times 10^{4}$ e $1,0 \times 10^{5}$ urediniósporos de $U$. appendiculatus por $\mathrm{mL}$.

No caso dos experimentos com a mancha angular, a primeira folha trifoliolada foi inoculada aos 13 dat, quando a largura máxima do folíolo central da mesma tinha de 3,5-5,5 cm. As concentrações, em conídios de $P$. griseola por $\mathrm{mL}$, utilizadas nos experimentos foram: $0,1,2 \times 10^{5}, 2,0 \times 10^{5}$ e $2,6 \times 10^{5}(\mathrm{M} 1) ; 0,5,9 \times 10^{4}, 9,5 \times 10^{4}$ e 2,0 $\times 10^{5}(\mathrm{M} 2) ; 0,6,2 \times 10^{4}, 1,2 \times 10^{5}$ e $2,5 \times 10^{5}(\mathrm{M} 3) ; 0,1,9 \times 10^{5}, 3,7 \times 10^{5}$ e $6,5 \times 10^{5}$ (M4).

Para a antracnose, quando a primeira folha trifoliolada tinha de $2,5-4,5 \mathrm{~cm}$ de largura máxima no folíolo central, aos 15-16 dat, esta mesma folha foi inoculada. As concentrações, em conídios de C. lindemuthianum por $\mathrm{mL}$, utilizadas nos experimentos 
$\mathrm{A} 1, \mathrm{~A} 2, \mathrm{~A} 3, \mathrm{~A} 4, \mathrm{~A} 5$ e A6 foram, respectivamente: $0,8,6 \times 10^{4}, 1,8 \times 10^{5}$ e $2,8 \times 10^{5} ; 0$, $1,9 \times 10^{5}, 3,9 \times 10^{5}$ e $7,7 \times 10^{5} ; 0,0,9 \times 10^{5}, 3,6 \times 10^{5}$ e $7,1 \times 10^{5} ; 0,7,5 \times 10^{4}, 1,8 \times 10^{5}$ e $8,3 \times 10^{5} ; 0,3,3 \times 10^{4}, 1,0 \times 10^{5}$ e $4,5 \times 10^{5} ; 0,1,9 \times 10^{5} ; 5,4 \times 10^{5}$ e $2,0 \times 10^{6}$.

Em todas as suspensões de esporos foi adicionada uma gota de tween 20 por $100 \mathrm{~mL}$ de suspensão. A inoculação foi feita por aspersão da suspensão de esporos em ambas as faces da folha escolhida até o ponto de escorrimento superficial. Imediatamente após a inoculação, as plantas foram mantidas em câmara de crescimento (Conviron, modelo E-7) cobertas por sacos plásticos umedecidos no escuro por 24 horas a $19^{\circ} \mathrm{C}$, no caso da ferrugem e da antracnose, ou por 30 horas a $24{ }^{\circ} \mathrm{C}$, no caso da mancha angular. As temperaturas de incubação foram as mesmas, independentemente da temperatura testada posteriormente, para garantir níveis de infecção semelhantes em todos tratamentos.

Após a incubação, os sacos plásticos foram retirados e as plantas colocadas de volta em câmaras de crescimento sob diferentes temperaturas em regime claro/escuro de 14/10 horas (PAR 180-230 $\mu \mathrm{mol} \mathrm{m} \mathrm{m}^{-2} \mathrm{~s}^{-1}$ ). As temperaturas constantes utilizadas foram 15,19 e $23^{\circ} \mathrm{C}$, no caso da ferrugem e antracnose, e 19,22 e $25^{\circ} \mathrm{C}$, no caso da mancha angular. Neste mesmo dia, para ferrugem, ou no dia seguinte, para antracnose e mancha angular, foi realizado o desponte e a desbrota das plantas retirando-se todas folhas acima da folha inoculada e todos brotos axilares. Ainda, as plantas foram adubadas após o desponte e a desbrota e após 5 dias com $100 \mathrm{~mL}$ de uma solução de nitrato de amônio na concentração de $0,35 \mathrm{~g}$ de $\mathrm{N}$ por litro de água.

Nos experimentos com a ferrugem, foram realizadas quatro avaliações, para cada temperatura, nos seguintes estádios da doença: aparecimento das primeiras pústulas esporulando; aproximadamente $50 \%$ das pústulas esporulando; $100 \%$ das pústulas esporulando; dois dias após atingir $100 \%$ das pústulas esporulando. Estes estádios corresponderam na temperatura de $23{ }^{\circ} \mathrm{C}$ aos $7,8,10$ e 12 dias após a inoculação (dai), a $19^{\circ} \mathrm{C}$, aos $8,9,10$ dai e 13 , e a $15^{\circ} \mathrm{C}$, aos $9,10,12$ e 14 dai.

No caso da mancha angular foram realizadas quatro avaliações, para cada temperatura, nos seguintes dai: $7,8,9$ e 10 , para $25^{\circ} \mathrm{C}, 8,9,10$ e 11 , para $22^{\circ} \mathrm{C}$, e 9 , 
10,11 e 12 , para $19^{\circ} \mathrm{C}$, que compreenderam estádios com os sintomas de pequenas áreas necróticas de 1 a $4 \mathrm{~mm}^{2}$ até manchas angulares necróticas entre 5 e $10 \mathrm{~mm}^{2}$.

Para a antracnose, foi realizada apenas uma avaliação por experimento, para cada temperatura porque as folhas com niveis altos de severidade morriam rapidamente impossibilitando uma avaliação posterior. Em função da data de aparecimento dos sintomas, severidade de doença obtida e temperatura testada houve uma variação na data de avaliação. Nas plantas mantidas a $15^{\circ} \mathrm{C}$ as avaliações foram feitas por volta dos 7 dai, a $19^{\circ} \mathrm{C}$, em torno dos 6 dai, e a $15^{\circ} \mathrm{C}$, em torno dos 5 dai.

As avaliações da taxa líquida de fotossíntese máxima (com saturação de luz) foram realizadas com o aparelho LI-6400 Portable Photosynthesis System (Li-Cor ${ }^{(\boxplus)}$ ) no foliolo central das folhas inoculadas durante, em média, 5 minutos por folíolo até que as leituras estabilizassem. As condições durante as avaliações foram as mesmas descritas no Capítulo 3.

Nos experimentos com ferrugem e mancha angular, após a primeira avaliação, a região do folíolo central que estava dentro da câmara de análise foi marcada para que as próximas avaliações fossem feitas no mesmo local.

Após cada avaliação, a região do folíolo central que estava dentro da câmara de análise $\left(6 \mathrm{~cm}^{2}\right)$ foi marcada com o auxílio de uma moldura e fotografada por uma câmara digital DC120 Zoom Digital Camera (Kodak DS ${ }^{\circledR}$ ) a $20 \mathrm{~cm}$ de distância, iluminada com 4 lâmpadas fluorescentes de $20 \mathrm{~W}$ (duas de cada lado). As imagens digitalizadas foram transferidas para um microcomputador e, posteriormente, foram processadas com $o$ programa SIARCS 3.0 como descrito no Capitulo 3.

Nas folhas com ferrugem foi considerada na avaliação da severidade de doença a área ocupada pela pústula e pelo halo amarelado ao redor da pústula. Para mancha angular, foi considerado como tecido doente a área necrótica (cinza ou marrom) e a área amarelada ao seu redor, quando houvesse. No caso da antracnose, além da lesão vermelho-amarronzada nas nervuras, também foi considerado afetado e doente o tecido murcho e/ou seco ainda verde da folha infectada. 


\subsubsection{Experimentos em campo}

Foram realizados dois experimentos no campo da área experimental do Setor de Fitopatologia, Departamento de Entomologia, Fitopatologia e Zoologia Agrícola, ESALQ/USP, envolvendo os três patógenos considerados.

No experimento 1, as cv. Rosinha G-2 e Carioca Comum foram semeadas, no dia 25 de março de 1999, com um espaçamento entre linhas de 0,4 m e uma população de 12 plantas por metro linear. Cada parcela foi constituída por quatro linhas com $4 \mathrm{~m} \mathrm{de}$ comprimento. Todas as práticas culturais recomendadas foram observadas, como adubação de plantio com $250 \mathrm{~kg}$ de NPK 04-14-08/ha, adubação de cobertura aos 21 dias após o plantio com $30 \mathrm{~kg}$ de $\mathrm{N} / \mathrm{ha}$ na forma de sulfato de amônio, capinas para manter a cultura no limpo até o fechamento da cultura, aplicação de inseticida methamidophos a cada duas semanas e irrigações periódicas de acordo com a necessidade.

Os estádios fenológicos da cultura, segundo van Schoonhoven \& PastorCorrales (1987), foram observados aos seguintes dias após o plantio (dap): 5 dap-V1, 8 dap-V2, 13 dap-V3, 20 dap-V4, 36 dap-R5, 40 dap-R6, 47 dap-R7 e 58 dap-R8. O campo foi destruído antes do estádio R9 porque houve mistura de doenças nas diferentes parcelas e para que os esporos produzidos nestas parcelas não passassem para as parcelas do experimento 2 instalado ao lado

Foram feitas cinco inoculações com $U$. appendiculatus $(15 / 04,24 / 04,30 / 04$, 07/05 e 12/05), quatro com C. lindemuthianum, (15/04, 30/04, 07/05 e 12/05) e quatro com P. griseola $(15 / 04,24 / 04,04 / 05$ e 12/05). Para as inoculações, foram feitas suspensões de esporos em água + tween na concentração de $10^{4}$ a $10^{5}$ esporos $/ \mathrm{mL}$. Cada suspensão foi aplicada por um pulverizador manual sobre e sob as folhas em sua respectiva parcela, sempre ao final da tarde (após as 17:00 h), sendo a parcela controle não inoculada e mantida sadia durante a maior parte do ciclo da cultura.

Com o início do aparecimento de sintomas foram iniciadas as avaliações para a determinação da relação entre severidade das doenças e taxa fotossintética em diferentes 
estádios fenológicos. As avaliações nas parcelas com antracnose foram feitas nos dias 26/04 (V4), 18/05 (R7) e 27/05 (R8 - só cv. Carioca Comum), com mancha angular, nos dias 11/05 (R7), 17/05 (R7) e 25/05 (R8) e com ferrugem, nos dias 12/05 (R7 - só cv. Rosinha G-2), 19/05 (R7) e 27/05 (R8 - só cv. Carioca Comum).

No experimento 2, a semeadura foi feita no dia 27 de abril de 1999, em área ao lado do experimento 1 com o mesmo espaçamento entre linhas e população de plantas por metro linear. Todas as práticas culturais executadas no primeiro experimento também foram realizadas neste segundo experimento.

Como o clima nesta época foi mais frio que o anterior houve um atraso nos estádios fenológicos da cultura, sendo estes observados alguns dias mais tarde em relação ao primeiro campo nos seguintes dias após o plantio (dap): 6 dap-V1, 10 dap-V2, 16 dap-V3, 31 dap-V4, 45 dap-R5, 52 dap-R6 e 62 dap-R7. O campo foi destruído antes do estádio R8 porque houve mistura de doenças nas diferentes parcelas.

Neste segundo experimento foram feitas quatro inoculações, como as descritas anteriormente, com os três patógenos separadamente nos dias 20/05, 31/05, 11/06 e 18/06 e mais duas somente com C. lindemuthianum e $P$. griseola nos dias 25/06 e 02/07. Uma parcela não inoculada foi mantida sadia durante a maior parte do ciclo da cultura.

Novamente, conforme o aparecimento de sintomas foram iniciadas as avaliações. Nas parcelas com antracnose foram feitas avaliações nos dias 08/06 (V4), 24/06 (R6 - só cv. Carioca Comum) e 02/07 (R7 - só cv. Rosinha G-2), com mancha angular, nos dias 22/06 (R6), 30/06 (R7) e 06/07 (R7) e com ferrugem, nos dias 09/06 (V4), 23/06 (R6) e 01/07 (R7).

As avaliações, nos dois experimentos, foram feitas sempre entre as 10:00 e 14:00 horas para se ter condições ambientes de temperatura, intensidade de irradiação solar, umidade relativa do ar e concentração de $\mathrm{CO}_{2}$ do ar relativamente constantes durante todo período de avaliação. Mesmo assim, utilizou-se a fonte de luz artificial do aparelho para garantir uma intensidade de irradiação fotossinteticamente ativa constante de $1000 \mu \mathrm{mol} \mathrm{m}^{-2} \mathrm{~s}^{-1}$, que no campo representa uma condição de saturação lumínica para o feijoeiro. 
Também, procurou-se avaliar folhas semelhantes quanto ao tamanho, idade fisiológica e posição da planta. Em cada avaliação foram utilizadas, em cada parcela, de 40 a 50 folhas com diferentes níveis de severidade de doença, incluindo 7 a 10 folhas sadias. Em cada folha avaliou-se a taxa fotossintética líquida do folíolo central até a estabilização das leituras (entre 1 a 2 minutos).

Após cada avaliação as folhas foram destacadas e a região do folíolo central que estava dentro da câmara de análise do aparelho foi marcada com o auxílio de uma moldura e a severidade de doença nesta região foi estimada pelo programa SIARCS 3.0 após o processamento da imagem digitalizada da mesma maneira descrita no Capítulo 3.

\subsubsection{Análise dos dados}

Com os dados de severidade da área avaliada, isto é, da proporção de área doente $(x)$, estimados pela análise de imagem e suas respectivas taxas fotossintéticas líquidas relativas $\left(P_{\mathrm{x}} / P_{0}\right)$, isto é, a razão entre a taxa fotossintética líquida da folha com severidade $x\left(P_{\mathrm{x}}\right)$ e a taxa fotossintética líquida média das folhas sadias $\left(P_{0}\right)$, foram feitos os gráficos que expressam a $P_{\mathrm{x}^{\prime}} / P_{0}$ em função da severidade de cada doença, para cada avaliação realizada, em cada tratamento, de cada experimento.

Por meio de análise de regressão não-linear, usando o programa STATISTICA (StatSoft, Tulsa, OK), a relação entre a severidade de doença e a taxa fotossintética líquida foi ajustada à eq. (1) proposta por Bastiaans (1991):

$$
P_{\mathrm{x}} / P_{0}=(1-x)^{\beta}
$$

sendo o parâmetro $\beta$ do modelo estimado para cada situação estudada. Os parâmetros $\beta$ estimados foram considerados maiores que 1 quando $(\beta-1) / S E$ foi maior que o valor de $\mathrm{t}$ da tabela a $1 \%$ de significância para $(n-2)$ graus de liberdade, onde $S E$ é o erro padrão do valor de estimado de $\beta$ e $n$ é o número de folhas avaliadas. 
A análise dos dados dos experimentos em câmara de crescimento foi feita separadamente para cada doença da seguinte forma: com os dados conjuntos de dois experimentos referentes à mesma época de avaliação dentro de cada temperatura e cultivar, os parâmetros $\beta$ foram estimados novamente. $O$ valor de $\beta$ estimado para determinada época de avaliação foi comparado com os valores estimados para outras épocas dentro da mesma temperatura e cultivar a fim de verificar se o parâmetro $\beta$ depende da época de avaliação. Posteriormente, juntando os dados dos experimentos, independentemente da época de avaliação, para determinada temperatura dentro de cada cultivar foi estimado um novo valor de $\beta$ e este foi comparado com cada valor estimado para cada temperatura dentro do cultivar para verificar a influência da temperatura na determinação do $\beta$. Finalmente, os dados dos experimentos para cada cultivar, independentemente da época de avaliação e da temperatura, foram unidos para a estimativa do parâmetro $\beta$ para cada cultivar, comparando-os novamente entre si.

Para os dados dos experimentos de campo, comparou-se da mesma forma os valores de $\beta$ estimados para cada estádio fenológico da cultura dentro de cada cultivar, independentemente do experimento. Unindo os dados dos dois experimentos, independentemente do estádio fenológico, estimou-se novo valor de $\beta$ para cada cultivar e estes foram comparados entre si.

Por fim, foi comparado o valor de $\beta$ estimado com os dados de todos experimentos em câmara de crescimento com o valor estimado para todos dados dos experimentos de campo. A comparação dos valores de $\beta$ estimados foi realizada aplicando o teste $t$ descrito por Campbell \& Madden (1990, p.195-197). 


\subsection{Resultados}

\subsubsection{Experimentos em câmaras de crescimento}

Nos experimentos com ferrugem, os níveis de severidade da área avaliada variaram entre 0 e $59 \%$ na primeira época de avaliação e entre 0 e $94 \%$ na quarta época. Com mancha angular, os níveis de severidade na primeira época de avaliação foram de 0 a $25 \%$ e na quarta, de 0 a $90 \%$. No caso da antracnose foram obtidos diversos níveis entre 0 e $100 \%$ de área doente na região avaliada.

Entre os experimentos a taxa fotossintética líquida das folhas sadias variam de 10 a $16 \mu \mathrm{mol} \mathrm{CO}_{2} \mathrm{~m}^{-2} \mathrm{~s}^{-1}$, mas a variação dentro da mesma avaliação nunca foi maior que $20 \%$ para mais ou para menos.

O modelo proposto por Bastiaans (1991) forneceu um bom ajuste aos dados de cada experimento, sendo as regressões significativas $(P<0,0001)$, a porcentagem da variância explicada pelo modelo $\left(\mathrm{R}^{2}\right)$ entre 35 e $98 \%$ (média de $83 \%$ ) e a distribuição da variância residual homogênea ao redor das curvas ajustadas, dando uma descrição quantitativa do efeito das três doenças foliares na fotossíntese das folhas de feijoeiro doentes (Figuras 01-14 do Apêndice 3). A relação entre a severidade de doença e a taxa fotossintética líquida relativa da folha doente pode, desta forma, ser expressa por um único parâmetro, $\beta$.

Para todas as doenças foi observada uma diminuição da taxa fotossintética líquida das folhas doentes com o aumento da severidade de doença. Entretanto, a redução da taxa fotossintética das folhas doentes foi maior que a severidade de doença na folha. Exceto em quatro casos referentes à ferrugem, nos outros 107 casos os valores de $\beta$ estimados foram maiores que $1(P<0,01)$. Para a ferrugem os valores estimados ficaram entre 2,004 e 2,507 (Tabela 01), para mancha angular entre 3,262 e 4,300 (Tabela 02) e para antracnose entre 7,261 e 9,601 (Tabela 03).

Entre as épocas de avaliação dentro de cada temperatura e cultivar não houve diferenças significativas $(P<0,01)$ nos experimentos com ferrugem, mancha angular e 
antracnose, mostrando não haver influência da época de avaliação ou estádio de desenvolvimento dos sintomas na determinação do valor de $\beta$ (Tabelas 01-03).

Quanto à influência da temperatura em que as plantas e as doenças se desenvolveram, sobre o valor de $\beta$, não foram observadas diferenças significativas entre os valores estimados para as diferentes temperaturas testadas dentro de cada cultivar para ferrugem e mancha angular. Para a antracnose, apesar da aparente tendência de que quanto maior a temperatura menor o valor de $\beta$ estimado, não foi encontrada diferença significativa a $1 \%$ entre as temperaturas dentro da cultivar, exceto entre 15 e $23{ }^{\circ} \mathrm{C}$ na cv. Carioca Comum (Tabela 04).

Entre as cultivares, os valores estimados de $\beta$ também não diferiram entre si dentro de cada doença a $1 \%$ de significância (Tabela 04) e quanto aos valores $\beta$ estimados incluindo todos os dados para cada doença, estes foram significativamente diferentes entre si, mostrando pelo menos nas cultivares testadas que este parâmetro depende quase que exclusivamente do tipo de patógeno ou do sintoma provocado pela doença.

$O$ valor de $\beta$ estimado \pm erro padrão, nos experimentos em câmara de crescimento, para a ferrugem foi de $2,155 \pm 0,025\left(\mathrm{R}^{2}=0,89, n=1724\right)$, para a mancha angular, 3,878 $\pm 0,040\left(\mathrm{R}^{2}=0,93, n=1695\right)$ e para antracnose, $8,200 \pm 0,167\left(\mathrm{R}^{2}=0,94\right.$, $n=677)$. 
Tabela 01. Valores de $\beta$ estimados para a ferrugem do feijoeiro em cada experimento, envolvendo as cv. Rosinha G-2 e Carioca Comum em diferentes temperaturas em ${ }^{\circ} \mathrm{C}(\mathrm{T})$ e épocas de avaliação em dias após a inoculação (dai).

\begin{tabular}{|c|c|c|c|c|c|c|c|c|c|c|c|}
\hline \multirow{2}{*}{$\mathbf{T}$} & \multirow[b]{2}{*}{ dai } & \multicolumn{5}{|c|}{ ROSINHA G-2 } & \multicolumn{5}{|c|}{ CARIOCA COMUM } \\
\hline & & Exp. & $\beta$ & $S E$ & $\mathbf{R}^{2}$ & $n$ & Exp. & $\beta$ & $S E$ & $\mathbf{R}^{2}$ & $n$ \\
\hline \multirow[t]{12}{*}{15} & 09 & Fl & $2,174 *$ & 0,135 & 0,87 & 39 & F3 & $2,371 *$ & 0,396 & 0,52 & 34 \\
\hline & & F2 & 2,116 & 0,829 & 0,95 & 38 & $\mathrm{~F} 4$ & $2,123 *$ & 0,307 & 0,63 & 37 \\
\hline & & F1+2 & 2,134 a & 0,070 & 0,94 & 77 & F3+4 & $2,216 \mathrm{a}$ & 0,243 & 0,59 & 71 \\
\hline & 10 & F1 & $2,067 *$ & 0,127 & 0,88 & 37 & F3 & $2,155 *$ & 0,254 & 0,63 & 37 \\
\hline & & $\mathrm{F} 2$ & $2,069 *$ & 0,096 & 0,94 & 37 & $\mathrm{~F} 4$ & $2,081 *$ & 0,207 & 0,80 & 34 \\
\hline & & $\mathbf{F} 1+2$ & $2,068 \mathrm{a}$ & 0,075 & 0,93 & 74 & $\mathrm{~F} 3+4$ & $2,122 \mathrm{a}$ & 0,166 & 0,72 & 71 \\
\hline & 12 & $\mathrm{Fl}$ & $2,066 *$ & 0,105 & 0,92 & 39 & F3 & $2,415^{*}$ & 0,138 & 0,88 & 35 \\
\hline & & F2 & $2,164 *$ & 0,107 & 0,94 & 38 & $\mathrm{~F} 4$ & $2,211 *$ & 0,185 & 0,87 & 36 \\
\hline & & F1+2 & $2,123 \mathrm{a}$ & 0,075 & 0,94 & 77 & F3+4 & $2,329 a$ & 0,112 & $\mathbf{0 , 8 8}$ & 71 \\
\hline & 14 & Fl & $2,027 *$ & 0,070 & 0,96 & 37 & F3 & $2,174 *$ & 0,143 & 0,84 & 34 \\
\hline & & F2 & $2,276^{*}$ & 0,130 & 0,92 & 38 & $\mathrm{~F} 4$ & $2,112 *$ & 0,216 & 0,83 & 38 \\
\hline & & $\mathrm{F} 1+2$ & 2,159 a & 0,075 & 0,94 & 75 & $\mathrm{F3}+4$ & 2,149 a & 0,123 & $\mathbf{0 , 8 4}$ & 72 \\
\hline \multirow[t]{12}{*}{19} & 08 & Fl & $2,315 *$ & 0,132 & 0,86 & 38 & F3 & $2,313 *$ & 0,432 & 0,46 & 33 \\
\hline & & F2 & $2,253 *$ & $0,14 \mathrm{I}$ & 0,88 & 38 & F4 & $2,405 *$ & 0,491 & 0,41 & 35 \\
\hline & & $\mathrm{F1}+2$ & $2,277 \mathrm{a}$ & 0,098 & $\mathbf{0 , 8 8}$ & 76 & F3+4 & $2,347 a$ & 0,318 & 0,44 & 68 \\
\hline & 09 & F1 & $2,071 *$ & 0,125 & 0,86 & 38 & F3 & $2,279 *$ & 0,227 & 0,62 & 35 \\
\hline & & $\mathrm{F} 2$ & $2,107 *$ & 0,085 & 0,94 & 38 & $\mathrm{~F} 4$ & $2,182 *$ & 0,252 & 0,67 & 32 \\
\hline & & $F 1+2$ & 2,092 a & 0,072 & 0,91 & 76 & $\mathrm{~F} 3+4$ & $2,250 \mathrm{a}$ & 0,167 & 0,67 & 67 \\
\hline & 11 & Fl & 2,033 & 0,912 & 0,94 & 38 & F3 & $2,336^{*}$ & 0,166 & 0,82 & 37 \\
\hline & & $\mathrm{F} 2$ & $2,153 *$ & 0,112 & 0,91 & 38 & $\mathrm{~F} 4$ & $2,137^{*}$ & 0,323 & 0,59 & 34 \\
\hline & & $F 1+2$ & $2,099 \mathrm{a}$ & 0,073 & 0,92 & 76 & $\mathrm{~F} 3+4$ & $2,284 \mathrm{a}$ & 0,155 & 0,75 & 71 \\
\hline & 13 & Fl & $2,128 *$ & 0,078 & 0,95 & 38 & F3 & $2,231^{*}$ & 0,173 & 0,78 & 35 \\
\hline & & F2 & $2,013 *$ & 0.085 & 0,95 & 38 & F4 & $2,012 *$ & 0,161 & 0,85 & 34 \\
\hline & & $\mathbf{F} 1+2$ & $2,066 \mathrm{a}$ & 0,059 & 0,95 & 76 & $\mathrm{~F} 3+4$ & $2,154 \mathrm{a}$ & 0,119 & $\mathbf{0 , 8 4}$ & 69 \\
\hline \multirow[t]{12}{*}{23} & 07 & Fl & 2,134 & 0,762 & 0,48 & 12 & F3 & 2,301 & 0,478 & 0,41 & 38 \\
\hline & & F2 & $2,267 *$ & 0.185 & 0,85 & 40 & $\mathrm{~F} 4$ & $2,497 *$ & 0,394 & 0,68 & 33 \\
\hline & & $F 1+2$ & $2,256 \mathrm{a}$ & 0,190 & 0,81 & 52 & F3+4 & $2,398 \mathrm{a}$ & 0,311 & 0,55 & 71 \\
\hline & 08 & Fl & $2,187 *$ & 0,249 & 0,75 & 34 & F3 & $2,136^{*}$ & 0,208 & 0,74 & 37 \\
\hline & & F2 & $2,004 *$ & 0,136 & 0,88 & 40 & $\mathrm{~F} 4$ & $2,162 *$ & 0,278 & 0,84 & 36 \\
\hline & & $F 1+2$ & $2,066 \mathrm{a}$ & 0,125 & 0,84 & 74 & $\mathrm{F3}+4$ & $2,145 \mathrm{a}$ & 0,162 & $\mathbf{0 , 8 0}$ & 73 \\
\hline & 10 & $\mathrm{Fl}$ & $2,198^{*}$ & 0,164 & 0,84 & 35 & F3 & $2,292 *$ & 0,143 & 0,89 & 36 \\
\hline & & $\mathrm{F} 2$ & $2,117 *$ & 0,136 & 0,92 & 40 & $\mathrm{~F} 4$ & $2,204 *$ & 0,207 & 0,90 & 34 \\
\hline & & $F 1+2$ & $2,153 \mathrm{a}$ & 0,105 & 0,89 & 75 & F3+4 & $2,268 \mathrm{a}$ & 0,115 & 0,90 & 70 \\
\hline & 12 & Fl & $2,038 *$ & 0,160 & 0,87 & 36 & $\mathrm{~F} 3$ & $2,145 *$ & 0,197 & 0,82 & 33 \\
\hline & & F2 & $2.055 *$ & 0.138 & 0,93 & 40 & F4 & $2,507 *$ & 0,257 & 0,89 & 33 \\
\hline & & $\mathrm{F} 1+2$ & $2,047 \mathrm{a}$ & 0,105 & 0,91 & 76 & $\mathrm{~F} 3+4$ & 2,265 a & 0,155 & $\mathbf{0 , 8 7}$ & 66 \\
\hline
\end{tabular}

$S E=$ erro padrão do valor de $\beta$ estimado

$\mathrm{R}^{2}=$ coeficiente de determinação.

$n=$ número de folhas avaliadas.

* = diferente de 1 pelo teste $t$ a $1 \%$ de significância.

Valores seguidos pela mesma letra minúscula nas colunas dentro de cada temperatura e cultivar não diferem entre si a $1 \%$ de significância pelo teste $t$. 
Tabela 02. Valores de $\beta$ estimados para a mancha angular do feijoeiro em cada experimento, envolvendo as cv. Rosinha G-2 e Carioca Comum em diferentes temperaturas em ${ }^{\circ} \mathrm{C}(\mathrm{T})$ e épocas de avaliação em dias após a inoculação (dai).

\begin{tabular}{|c|c|c|c|c|c|c|c|c|c|c|c|}
\hline \multirow{2}{*}{$\mathbf{T}$} & \multirow[b]{2}{*}{ dai } & \multicolumn{5}{|c|}{ ROSINHA G-2 } & \multicolumn{5}{|c|}{ CARIOCA COMUM } \\
\hline & & Exp. & $\beta$ & $\boldsymbol{S E}$ & $\mathbf{R}^{2}$ & $n$ & Exp. & $\beta$ & $\boldsymbol{S E}$ & $\mathbf{R}^{2}$ & $n$ \\
\hline \multirow[t]{12}{*}{19} & 09 & M1 & - & - & - & - & M3 & $4,274 *$ & 0,620 & 0,49 & 34 \\
\hline & & M2 & $3,931 *$ & 0,321 & 0,86 & 26 & M4 & $3,494 *$ & 0,228 & 0,90 & 37 \\
\hline & & $\mathbf{M 1 + 2}$ & 3,931 a & 0,321 & $\mathbf{0 , 8 6}$ & 26 & M3+4 & 3,638 a & 0,238 & $\mathbf{0 , 8 1}$ & 71 \\
\hline & 10 & M1 & $4,124 *$ & 0,282 & 0,92 & 35 & M3 & $4,199 *$ & 0,326 & 0,68 & 39 \\
\hline & & M2 & $4,189 *$ & 0,262 & 0,93 & 31 & M4 & $3,735 *$ & 0,265 & 0,88 & 39 \\
\hline & & $\mathbf{M 1 + 2}$ & $4,146 \mathrm{a}$ & 0,198 & 0,93 & 66 & M3+4 & 3,909 a & 0,216 & $\mathbf{0 , 8 4}$ & 78 \\
\hline & 11 & M1 & $3,844^{*}$ & 0,151 & 0,98 & 36 & M3 & $4,232 *$ & 0,213 & 0,89 & 38 \\
\hline & & M2 & $4,072 *$ & 0,173 & 0,97 & 30 & M4 & $3,330 *$ & 0,178 & 0,93 & 37 \\
\hline & & $\mathbf{M 1 + 2}$ & 3,948 a & 0,112 & 0,98 & 66 & $\mathbf{M} 3+4$ & $3,703 \mathrm{a}$ & 0,160 & 0,91 & 75 \\
\hline & 12 & M1 & $3,944 *$ & 0,186 & 0,97 & 37 & M3 & $4,118 *$ & 0,179 & 0,95 & 40 \\
\hline & & M2 & $4,181 *$ & 0,169 & 0,98 & 34 & M4 & $3,438 *$ & 0,235 & 0,94 & 36 \\
\hline & & M1+2 & $4,071 \mathrm{a}$ & 0,122 & 0,97 & 71 & M3+4 & 3,851 a & 0,152 & 0,94 & 76 \\
\hline \multirow[t]{12}{*}{22} & 08 & M1 & - & - & - & - & M3 & $3,862 *$ & 0,464 & 0,62 & 40 \\
\hline & & M2 & $4,120 *$ & 0,349 & 0,73 & 40 & M4 & $3,386 *$ & 0,263 & 0,86 & 38 \\
\hline & & M1+2 & $4,120 \mathrm{a}$ & 0,349 & 0,73 & 40 & M3+4 & 3,489 a & 0,227 & 0,81 & 78 \\
\hline & 09 & M1 & $4,078 *$ & 0,417 & 0,71 & 40 & M3 & $4,033 *$ & 0,231 & 0,83 & 40 \\
\hline & & M2 & $4,014 *$ & 0,176 & 0,93 & 40 & M4 & $3,454 *$ & 0,314 & 0,84 & 40 \\
\hline & & M1+2 & 4,052 a & 0,240 & $\mathbf{0 , 8 1}$ & 80 & M3+4 & 3,702 a & 0,208 & $\mathbf{0 , 8 4}$ & 80 \\
\hline & 10 & M1 & $3,928 *$ & 0,249 & 0,91 & 40 & M3 & $4,161 *$ & 0,144 & 0,93 & 38 \\
\hline & & M2 & $3,262 *$ & 0,162 & 0,92 & 40 & M4 & $4,043 *$ & 0,267 & 0,94 & 34 \\
\hline & & M1+2 & $3,597 \mathrm{a}$ & 0,143 & 0,92 & 80 & M3+4 & $4,102 \mathrm{a}$ & 0,149 & 0,94 & 72 \\
\hline & 11 & M1 & $3,787 *$ & 0,250 & 0,93 & 39 & M3 & $4,219 *$ & 0,156 & 0,96 & 37 \\
\hline & & M2 & $3,811 *$ & 0,175 & 0,95 & 40 & M4 & $3,434 *$ & 0,175 & 0,96 & 40 \\
\hline & & M1+2 & $3,799 \mathrm{a}$ & 0,151 & 0,94 & 79 & $\mathrm{M} 3+4$ & 3,846 a & 0,125 & 0,95 & 77 \\
\hline \multirow[t]{12}{*}{25} & 07 & M1 & - & - & - & - & M3 & $4,286 *$ & 1,113 & 0,35 & 33 \\
\hline & & M2 & $3,893 *$ & 0,632 & 0,41 & 40 & M4 & $3,443 *$ & 0,619 & 0,50 & 40 \\
\hline & & $\mathrm{M} 1+2$ & $3,893 a$ & 0,632 & 0,41 & 40 & M3+4 & $3,636 \mathrm{a}$ & 0,534 & 0,44 & 73 \\
\hline & 08 & M1 & $3,591 *$ & 0,383 & 0,73 & 39 & M3 & $4,264 *$ & 0,312 & 0,83 & 35 \\
\hline & & M2 & $4,015 *$ & 0,345 & 0,74 & 40 & M4 & $4,068 *$ & 0,235 & 0,94 & 35 \\
\hline & & M1+2 & $3,743 \mathrm{a}$ & 0,265 & 0,76 & 79 & M3+4 & $4,170 \mathrm{a}$ & 0,197 & $\mathbf{0 , 8 9}$ & 70 \\
\hline & 09 & M1 & $4,276^{*}$ & 0,388 & 0,85 & 40 & M3 & $4,096 *$ & 0,298 & 0,85 & 40 \\
\hline & & M2 & $3,871 *$ & 0,223 & 0,90 & 40 & M4 & $3,942 *$ & 0,373 & 0,84 & 40 \\
\hline & & M1+2 & $4,047 \mathrm{a}$ & 0,210 & 0,87 & 80 & M3+4 & $4,023 \mathrm{a}$ & 0,239 & $\mathbf{0 , 8 4}$ & 80 \\
\hline & 10 & M1 & $3,854 *$ & 0,292 & 0,92 & 41 & M3 & $4,300 *$ & 0,234 & 0,93 & 37 \\
\hline & & M2 & $3,374 *$ & 0,150 & 0,97 & 40 & M4 & $3,691 *$ & 0,236 & 0,92 & 40 \\
\hline & & $\mathbf{M 1 + 2}$ & 3,579 a & 0,155 & $\mathbf{0 , 9 4}$ & 81 & M3+4 & $3,992 \mathrm{a}$ & 0,183 & 0,92 & 77 \\
\hline
\end{tabular}

$S E=$ erro padrão do valor de $\beta$ estimado.

$\mathrm{R}^{2}=$ coeficiente de determinação.

$n=$ número de folhas avaliadas.

* = diferente de 1 pelo teste $\mathrm{t} \mathrm{a} 1 \%$ de significância.

Valores seguidos pela mesma letra minúscula nas colunas dentro de cada temperatura e cultivar não diferem entre si a $1 \%$ de significância pelo teste $t$. 
Tabela 03. Valores de $\beta$ estimados para a antracnose do feijoeiro em cada experimento envolvendo as cv. Rosinha G-2 e Carioca Comum em diferentes temperaturas em ${ }^{\circ} \mathrm{C}(\mathrm{T})$ e épocas de avaliação em dias após a inoculação (dai).

\begin{tabular}{|c|c|c|c|c|c|c|c|c|c|c|c|}
\hline & & \multicolumn{5}{|c|}{ ROSINHA G-2 } & \multicolumn{5}{|c|}{ CARIOCA COMUM } \\
\hline $\mathbf{T}$ & dai & Exp. & $\beta$ & $S E$ & $\mathbf{R}^{2}$ & $n$ & Exp. & $\beta$ & $S E$ & $\mathbf{R}^{2}$ & $n$ \\
\hline \multirow[t]{4}{*}{15} & 09 & Al & $9,601 *$ & 0,905 & 0,76 & 34 & A4 & $9,559 *$ & 0,844 & 0,97 & 37 \\
\hline & 07 & A2 & $7,755 *$ & 0,513 & 0,96 & 40 & A5 & $9,105 *$ & 0,461 & 0,95 & 37 \\
\hline & 07 & A3 & $8,739 *$ & 1,090 & 0,78 & 38 & A6 & $8,443 *$ & 0,940 & 0,97 & 39 \\
\hline & & $\mathbf{A} 1+2+3$ & 8,652 & 0,456 & 0,92 & 112 & $A 4+5+6$ & 9,115 & 0,386 & 0,97 & 113 \\
\hline \multirow[t]{4}{*}{19} & 07 & $\mathrm{Al}$ & $9,180 *$ & 1,070 & 0,84 & 28 & A4 & $8,280 *$ & 0,567 & 0,96 & 38 \\
\hline & 06 & A2 & $7,694 *$ & 0,603 & 0,94 & 40 & A5 & 8,578 * & 0,526 & 0,95 & 39 \\
\hline & 06 & A3 & $8,448 *$ & 0,871 & 0,84 & 40 & A6 & $7,261 *$ & 0,467 & 0,96 & 40 \\
\hline & & $\mathrm{A} 1+2+3$ & 8,204 & 0,459 & 0,93 & 108 & $A 4+5+6$ & 8,064 & 0,304 & 0,95 & 117 \\
\hline \multirow[t]{4}{*}{23} & 06 & Al & $8,195 *$ & 1,014 & 0,71 & 34 & A4 & $7,342 *$ & 0,475 & 0,96 & 38 \\
\hline & 05 & A2 & $7,891 *$ & 0,735 & 0,95 & 38 & A5 & $7,972 *$ & 0,768 & 0,67 & 39 \\
\hline & 05 & A3 & $7,818 *$ & 0,652 & 0,92 & 39 & A6 & $7,560 *$ & 0,678 & 0,91 & 39 \\
\hline & & $\mathbf{A} 1+2+3$ & 7,995 & 0,460 & 0,92 & 111 & $\mathrm{~A} 4+5+6$ & 7,650 & $\mathbf{0 , 3 8 4}$ & 0,90 & 116 \\
\hline
\end{tabular}

$S E=$ erro padrão do valor de $\beta$ estimado.

$\mathrm{R}^{2}=$ coeficiente de determinação.

$n=$ número de folhas avaliadas.

* = diferente de 1 e não difere dos demais valores dentro da mesma temperatura e cultivar pelo teste $\mathrm{ta} 1$

$\%$ de significância. 
Tabela 04. Valores de $\beta$ estimados para a ferrugem, mancha angular e antracnose do feijoeiro em cada temperatura em ${ }^{\circ} \mathrm{C}(\mathrm{T})$ testada dentro da cultivar independentemente da época de avaliação.

\begin{tabular}{c|c|cccc|cccc}
\hline & & \multicolumn{4}{|c|}{ ROSINHA G-2 } & \multicolumn{3}{c}{ CARIOCA COMUM } \\
\hline Doença & $\mathbf{T}$ & $\boldsymbol{\beta}$ & $\boldsymbol{S E}$ & $\mathbf{R}^{\mathbf{2}}$ & $\boldsymbol{n}$ & $\boldsymbol{\beta}$ & $\boldsymbol{S E}$ & $\mathbf{R}^{\mathbf{2}}$ & $\boldsymbol{n}$ \\
\hline Ferrugem & 15 & $2,122 \mathrm{a}$ & 0,038 & 0,88 & 303 & $2,207 \mathrm{a}$ & 0,071 & 0,83 & 285 \\
& 19 & $2,116 \mathrm{a}$ & 0,037 & 0,93 & 304 & $2,223 \mathrm{a}$ & 0,078 & 0,79 & 275 \\
& 23 & $2,110 \mathrm{a}$ & 0,062 & 0,89 & 277 & $2,251 \mathrm{a}$ & 0,084 & 0,84 & 280 \\
& Geral & $\mathbf{2 , 1 1 7} \mathbf{A}$ & $\mathbf{0 , 0 2 7}$ & $\mathbf{0 , 9 2}$ & $\mathbf{8 8 4}$ & $\mathbf{2 , 2 2 7} \mathbf{A}$ & $\mathbf{0 , 0 4 5}$ & $\mathbf{0 , 8 2}$ & $\mathbf{8 4 0}$ \\
& & & & & & & & & \\
\hline Mancha & 19 & $4,047 \mathrm{a}$ & 0,077 & 0,97 & 229 & $3,791 \mathrm{a}$ & 0,088 & 0,92 & 300 \\
& 22 & $3,804 \mathrm{a}$ & 0,096 & 0,91 & 279 & $3,853 \mathrm{a}$ & 0,082 & 0,93 & 307 \\
& 25 & $3,802 \mathrm{a}$ & 0,117 & 0,90 & 280 & $4,016 \mathrm{a}$ & 0,115 & 0.89 & 300 \\
& $\mathbf{G e r a l}$ & $\mathbf{3 , 8 7 3} \mathbf{A}$ & $\mathbf{0 , 0 5 9}$ & $\mathbf{0 , 9 3}$ & $\mathbf{7 8 8}$ & $\mathbf{3 , 8 8 4} \mathbf{A}$ & $\mathbf{0 , 0 5 5}$ & $\mathbf{0 , 9 1}$ & $\mathbf{9 0 7}$ \\
& & & & & & & & & \\
\hline Antracnose & 15 & $\mathbf{8 , 6 5 2} \mathrm{a}$ & 0,456 & 0,92 & 112 & $\mathbf{9 , 1 1 5} \mathrm{a}$ & 0,386 & 0,97 & 113 \\
& 19 & $\mathbf{8 , 2 0 4} \mathrm{a}$ & 0,459 & 0,93 & 108 & $\mathbf{8 , 0 6 4} \mathrm{ab}$ & 0,304 & 0,95 & 117 \\
& 23 & $\mathbf{7 , 9 9 5} \mathrm{a}$ & 0,460 & 0,92 & 111 & $\mathbf{7 , 6 5 0} \mathrm{b}$ & 0,384 & 0,90 & 116 \\
& Geral & $\mathbf{8 , 2 9 4} \mathbf{A}$ & $\mathbf{0 , 2 6 5}$ & $\mathbf{0 , 9 2}$ & $\mathbf{3 3 1}$ & $\mathbf{8 , 1 3 2} \mathbf{A}$ & $\mathbf{0 , 2 0 8}$ & $\mathbf{0 , 9 4}$ & $\mathbf{3 4 6}$ \\
\hline
\end{tabular}

$S E=$ erro padrão do valor de $\beta$ estimado.

$\mathrm{R}^{2}=$ coeficiente de determinação

$n=$ número de folhas avaliadas.

Valores seguidos pela mesma letra minúscula nas colunas dentro de cada doença e cultivar não diferem entre si a $1 \%$ de significância pelo teste t.

Valores seguidos pela mesma letra maiúscula nas linhas dentro de cada doença não diferem entre si a 1 \% de significância pelo teste $\mathrm{t}$. 


\subsubsection{Experimentos em campo}

Nos experimentos com ferrugem, os níveis de severidade da área avaliada variaram entre 0 e $25 \%$ no primeiro experimento e entre 0 e $78 \%$ no segundo. Com mancha angular, os níveis de severidade no primeiro experimento foram de 0 a $77 \%$ e no segundo, de 0 a $92 \%$. No caso da antracnose foram obtidos diversos níveis de severidade, mas nunca maiores que $10 \%$ de área doente na região avaliada em ambos experimentos.

Entre os experimentos, a taxa fotossintética líquida das folhas sadias variou de 17 a $25 \mu \mathrm{mol} \mathrm{CO} \mathrm{CO}^{-2} \mathrm{~s}^{-1}$, mas a variação dentro da mesma avaliação nunca foi maior que $20 \%$ para mais ou para menos.

Novamente, o modelo proposto por Bastiaans (1991) forneceu um bom ajuste aos dados de cada experimento, sendo as regressões significativas $(P<0,0001)$ e com valores de $\mathrm{R}^{2}$ entre 30 e $91 \%$ (média de $73 \%$ ) menores que os obtidos nos experimentos em câmara de crescimento com condições de ambiente controlado mesmo tentando-se amenizar as variações entre as folhas avaliadas e as condições de avaliação (Figuras 1520 do Apêndice 3).

Confirmando os experimentos em câmara de crescimento, todos os valores de $\beta$ estimados foram, a $1 \%$ de significância, maiores que 1. Para a ferrugem os valores estimados para cada estádio fenológico da cultura ficaram entre 2,154 e 2,413, para mancha angular entre 3,421 e 3,904 e para antracnose entre 6,486 e 7,881 (Tabela 05).

Entre as épocas de avaliação (estádio fenológico da cultura) dentro de cada cultivar não houve diferença significativa $(P<0,01)$ nos experimentos com ferrugem, mancha angular e antracnose, mostrando não haver influência do estádio fenológico da cultura na determinação do valor de $\beta$. Da mesma forma, confirmando os resultados dos experimentos em câmara de crescimento, não houve diferença entre os valores estimados de $\beta$ para cada cultivar dentro de cada doença a $1 \%$ de significância (Tabela 05 ).

Quanto aos valores $\beta$ estimados, incluindo todos os dados para cada doença, estes foram significativamente diferentes entre si $(P<0,01)$. $O$ valor de $\beta$ estimado \pm erro 
padrão, nos experimentos em campo, para a ferrugem foi de $2,290 \pm 0,058\left(R^{2}=0,82\right.$, $n=480)$, para a mancha angular, $3,605 \pm 0,074\left(\mathrm{R}^{2}=0,83, n=592\right)$ e para antracnose, $7,148 \pm 0,196\left(\mathrm{R}^{2}=0,67, n=389\right)$.

Comparando os valores de $\beta$ obtidos nos experimentos em câmara de crescimento com os valores obtidos em campo, não foi observada diferença significativa a $1 \%$ entre os dados de ferrugem, mas sim entre os dados de mancha angular e antracnose. Para estas duas últimas doenças, os valores estimados pelas avaliações em condições de campo foram um pouco menores que os valores estimados em condições de ambiente controlado das câmaras de crescimento. Apesar de especulativas, duas hipóteses foram sugeridas para explicar esta diferença: (i) maiores variações entre as leituras devido à menor homogeneidade das folhas avaliadas nos experimentos em campo constatada pelos menores $\mathrm{R}^{2}$ obtidos nos ajustes dos dados ao modelo nestes experimentos; (ii) valores menores de $\beta$ indicam que o efeito dos patógenos sobre a fotossíntese está mais restrito à lesão visível causada pelo patógeno e no caso dos experimentos em campo a maior intensidade de irradiação tornaria maior o efeito da fotoinibição sobre as áreas afetadas juntamente com uma melhor definição das área com sintomas. No caso dos experimentos em câmaras de crescimento, o efeito dos patógenos ao redor da área considerada com sintoma estaria menos visível pela menor ocorrência de fotoinibição nestas condições.

Apesar desta pequena diferença entre os valores de $\beta$ estimados em condições controlas e em condições de campo, foram unidos todos os dados de ambos experimentos e estimou-se um valor único de $\beta$ para cada doença (Figura 01 ). O valor único de $\beta$ estimado \pm erro padrão para a ferrugem foi de $2,173 \pm 0,023\left(R^{2}=0,88\right.$, $n=2204)$, para a mancha angular, $3,809 \pm 0,036\left(\mathrm{R}^{2}=0,91, n=2287\right)$ e para antracnose, $7,972 \pm 0,128\left(\mathrm{R}^{2}=0,94, n=1066\right)$ 
Tabela 05. Valores de $\beta$ estimados para a ferrugem, mancha angular e antracnose do feijoeiro em cada estádio fenológico da cultura (EF) avaliado dentro da cultivar.

\begin{tabular}{|c|c|c|c|c|c|c|c|c|c|c|c|}
\hline & & \multicolumn{5}{|c|}{ ROSINHA G-2 } & \multicolumn{5}{|c|}{ CARIOCA COMUM } \\
\hline Doença & Exp. & EF & $\beta$ & $\boldsymbol{S E}$ & $\mathbf{R}^{2}$ & $n$ & EF & $\beta$ & $S E$ & $\mathbf{R}^{2}$ & $n$ \\
\hline \multirow[t]{6}{*}{ Ferrugem } & 1 & $\mathbf{R 7}$ & $2,262 \mathrm{a}$ & 0,327 & 0,53 & 56 & $\mathbf{R 7}$ & $2,376 \mathrm{a}$ & 0,351 & 0,30 & 44 \\
\hline & & R7 & $2,262 \mathrm{a}$ & 0,276 & 0,53 & 41 & $\mathbf{R 8}$ & $2,413 \mathrm{a}$ & 0,235 & 0,69 & 43 \\
\hline & 2 & V4 & $2,336 \mathrm{a}$ & 0,162 & 0,90 & 50 & V4 & $2,412 \mathrm{a}$ & 0,185 & 0,72 & 44 \\
\hline & & R6 & $2,154 \mathrm{a}$ & 0,152 & 0,80 & 52 & R6 & $2,310 \mathrm{a}$ & 0,180 & 0,80 & 47 \\
\hline & & $\mathbf{R 7}$ & $2,189 \mathrm{a}$ & 0,118 & 0,91 & 53 & $\mathbf{R 7}$ & $2,359 \mathrm{a}$ & 0,147 & 0,85 & 50 \\
\hline & $1+2$ & & $2,232 \mathrm{~A}$ & 0,078 & 0,84 & 252 & & $2,370 \mathrm{~A}$ & 0,085 & 0,76 & 228 \\
\hline \multirow[t]{7}{*}{ Mancha } & 1 & $\mathbf{R 7}$ & $3,446 \mathrm{a}$ & 0,256 & 0,72 & 49 & $\mathbf{R 7}$ & $3,904 \mathbf{a}$ & 0,323 & 0,82 & 45 \\
\hline & & R7 & $3,448 \mathrm{a}$ & 0.331 & 0,72 & 49 & $\mathbf{R 7}$ & $3,858 \mathrm{a}$ & 0,414 & 0,55 & 48 \\
\hline & & $\mathbf{R 8}$ & $3,548 \mathrm{a}$ & 0,272 & 0,76 & 50 & $\mathbf{R 8}$ & $3,616 \mathrm{a}$ & 0,279 & 0,84 & 50 \\
\hline & 2 & R6 & $3,584 \mathrm{a}$ & 0.215 & 0,85 & 52 & R6 & $3,842 \mathrm{a}$ & 0,286 & 0,86 & 50 \\
\hline & & R7 & 3,421 a & 0,171 & 0,90 & 49 & $\mathbf{R 7}$ & $3,837 \mathrm{a}$ & 0,340 & 0,84 & 50 \\
\hline & & R7 & $3,488 \mathrm{a}$ & 0,169 & 0,91 & 47 & $\mathbf{R 7}$ & $3,520 \mathrm{a}$ & 0,235 & 0,86 & 53 \\
\hline & $1+2$ & & $3,493 \mathrm{~A}$ & 0,092 & $\mathbf{0 , 8 2}$ & 296 & & $3,752 \mathrm{~A}$ & 0,119 & 0,83 & 296 \\
\hline \multirow[t]{6}{*}{ Antracnose } & 1 & V4 & $6,486 \mathrm{a}$ & 0,462 & 0,66 & 40 & V4 & $7,549 \mathrm{a}$ & 0,462 & 0,76 & 44 \\
\hline & & $\mathbf{R 7}$ & $7,331 \mathrm{a}$ & 0,768 & 0,77 & 45 & $\mathbf{R} 7$ & 7,881 a & 0,997 & 0,46 & 44 \\
\hline & & & & & & & $\mathbf{R 8}$ & 7,559 a & 0,740 & 0,45 & 44 \\
\hline & 2 & V4 & $6,709 a$ & 0,436 & 0,79 & 46 & V4 & 6,981 a & 0,608 & 0,71 & 40 \\
\hline & & $\mathbf{R 7}$ & $7,185 \mathrm{a}$ & 0.480 & 0,76 & 45 & R6 & $7,311 \mathrm{a}$ & 0,611 & 0,59 & 41 \\
\hline & $1+2$ & & $6,927 \mathrm{~A}$ & 0,269 & 0,72 & 176 & & $7,418 \mathrm{~A}$ & 0,298 & 0,61 & 213 \\
\hline
\end{tabular}

$S E=$ erro padrão do valor de $\beta$ estimado.

$\mathrm{R}^{2}=$ coeficiente de determinação.

$n=$ número de folhas avaliadas.

Valores seguidos pela mesma letra minúscula nas colunas dentro de cada doença e cultivar não diferem entre si a $1 \%$ de significância pelo teste t.

Valores seguidos pela mesma letra maiúscula nas linhas dentro de cada doença não diferem entre si a 1 $\%$ de significância pelo teste $t$. 

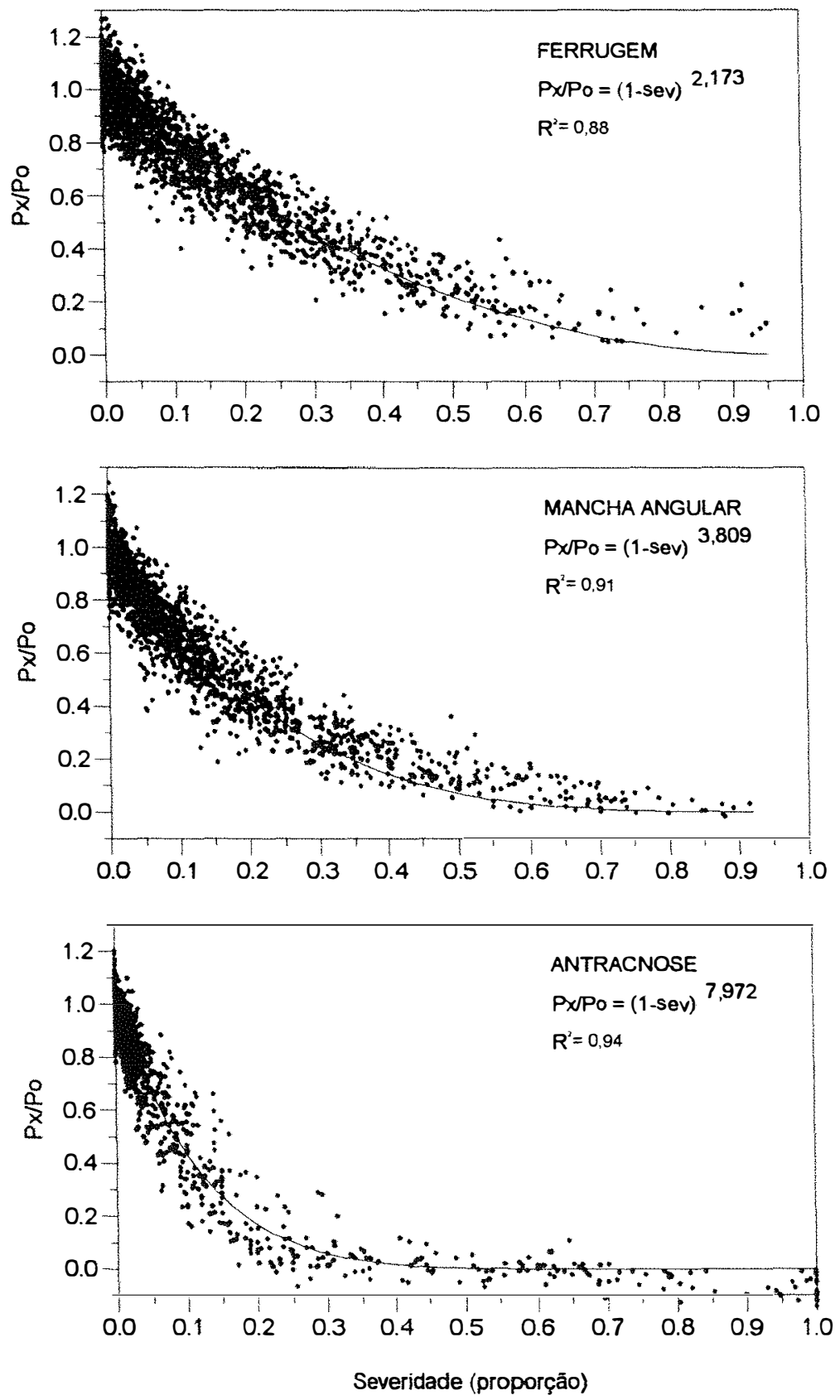

Figura 01. Relação entre a taxa fotossintética líquida relativa $\left(P_{\mathrm{x}} / P_{0}\right)$ e a severidade de ferrugem, mancha angular e antracnose em foliolos de feijoeiro. 


\subsection{Discussão}

A lesão virtual abrange a lesão visual e uma área adjacente na qual a atividade fotossintética é nula. Este conceito foi introduzido por Bastiaans (1991) como a base para um modelo que quantifica a capacidade fotossintética de folhas doentes. A relação entre a severidade de doença e a fotossintese é descrita por um único parâmetro, $\beta$.

A determinação do valor de $\beta$, pela eq. (1), depende da confiabilidade da estimativa da taxa fotossintética líquida média das folhas sadias $\left(P_{0}\right)$, da taxa fotossintética líquida das folhas doentes $\left(P_{\mathrm{x}}\right)$ com uma ampla gama de severidade e da proporção da área afetada pela doença. Para reduzir a variação nos valores das taxas fotossintéticas quando for determinar o parâmetro $\beta$, as mesmas devem ser avaliadas na condição de saturação lumínica (Bastiaans, 1991), se possível, folhas de idades e posição na planta similares devem ser selecionadas para as avaliações (Goodwin, 1992; Shtienberg, 1992) e as condições ambientes nas quais as medidas serão tomadas não devem ser muito diferentes das condições nas quais as plantas foram crescidas (Daly, 1976).

A avaliação da proporção da área doente também afeta diretamente os valores de $\beta$. Para doenças que não apresentam sintomas claramente definidos, certamente é mais dificil avaliar a severidade acuradamente. Geralmente, a avaliação da severidade de doenças tem sido feita com o auxílio de escalas diagramáticas, mas esta avaliação é sempre mais subjetiva que a análise de imagens em computador, pois está sujeita aos problemas inerentes à vista humana, além de depender da prática e bom senso do avaliador.

Avaliações de severidade nos estádios iniciais de desenvolvimento dos sintomas podem resultar num valor de $\beta$ diferente daquele obtido quando os sintomas estão mais avançados. Em um experimento preliminar, Lopes (1999) obteve um valor de $\beta$ em torno de 4,7 em folhas de feijoeiro com ferrugem apresentando sintomas de fleck, mas quatro dias mais tarde, quando os sintomas estavam bem desenvolvidos, com halos cloróticos ao redor das pústulas esporulando, o valor de $\beta$ foi 1,27 . No estádio de fleck, dificilmente 
todas as infecções bem sucedidas de ferrugem já estão visíveis, algumas ainda estão latentes e, portanto, não são consideradas na avaliação da severidade mesmo que já estejam afetando a fotossíntese na região infectada. Neste trabalho, para as avaliações feitas em diferentes estádios de desenvolvimento da doença, tanto para a ferrugem como para a mancha angular e antracnose do feijoeiro, não foram encontradas diferenças significativas entre os valores de $\beta$ estimados uma vez que o número de lesões e os sintomas na primeira época de avaliação já se apresentavam bem definidos. Nos experimentos em campo, freqüentemente, nas folhas avaliadas haviam ao mesmo tempo diferentes tipos de sintomas em diferentes estádios de desenvolvimento resultantes de diferentes épocas de infecção e ciclos dos patógenos. Entretanto, apesar da maior variabilidade, os valores de $\beta$ estimados nas condições de campo foram próximos dos valores obtidos de folhas inoculadas uma única vez (monociclo) nos experimentos em câmaras de crescimento. Goodwin (1992) obteve diferenças insignificantes entre duas avaliações distintas espaçadas em 3 dias nos valores de $\beta$ estimados para o crestamento bacteriano comum do feijoeiro.

O efeito da temperatura está mais associado à velocidade de crescimento das plantas e do desenvolvimento das doenças e seus sintomas do que com o efeito das doenças na atividade fotossintética das folhas doentes, como mostrada pela ausência de diferença entre os valores de $\beta$ obtidos para as doenças desenvolvidas em diferentes temperaturas. Da mesma forma, um possível efeito do estádio fenológico da cultura, caracterizado por mudanças na redistribuição de fotoassimilados na planta, sobre a determinação do parâmetro $\beta$ não foi observado. Lopes (1999) observou que o estresse nutricional teve muito pouco impacto sobre os valores de $\beta$ estimados para folhas de feijoeiro com ferrugem ou antracnose. Conseqüentemente, pode-se concluir que o valor de $\beta$ é intrínseco à doença e ao efeito do patógeno sobre a fotossíntese do hospedeiro. Fatores de estresse abióticos que poderiam afetam a fotossintese das folhas também afetam, simultaneamente e do mesmo modo, o desenvolvimento da doença e o aparecimento dos sintomas. 
Logicamente, que a doença, além do ambiente, depende do patógeno e do hospedeiro e, portanto, seria esperado que, para diferentes raças do patógeno ou diferentes cultivares, diferentes valores de $\beta$ fossem obtidos. Como freqüentemente mais de uma raça do patógeno ocorre em condições de campo e geralmente o campo é cultivado com uma única cultivar, estudos sobre a influência de raças específicas do patógeno sobre a determinação do $\beta$ parecem ser menos importantes quando se pensa na aplicação deste parâmetro em experimentos de avaliação de danos.

Diferenças no valor de $\beta$ entre cultivares implicariam em diferenças genotípicas em tolerância. Tolerância é aqui definida como a capacidade da planta suportar a infecção com pouca redução na sua atividade fotossintética. Cultivares com maior tolerância apresentariam menores reduções na atividade fotossintética que cultivares menos tolerantes para um mesmo nível de severidade de doença, sendo menor o valor de $\beta$ estimado para estas cultivares. Em todas as doenças estudadas, não houve diferença nos valores de $\beta$ entre a cv. Rosinha G-2 e a cv. Carioca Comum, mostrando que não há diferenças quanto à tolerância das folhas doentes de cada cultivar às doenças. A cv. Carioca Comum geralmente apresenta uma maior resistência à ferrugem, mancha angular e antracnose em relação à cv. Rosinha G-2 expressa em uma menor eficiência relativa de infeç̧ão (menor número de lesões por área foliar) ou em maiores períodos de incubação e latência (Bacchi, 1993; Bassanezi, 1995; Dalla Pria, 1997; Mendes \& Bergamin Filho, 1989; Mendes \& Bergamin Filho, 1990; Sartorato, 1989; Sartorato \& Rava, 1992). Estes resultados corroboram com o trabalho de Bastiaans \& Roumen (1993) que também não encontraram diferenças significativas nos valores de $\beta$ estimados para três cultivares de arroz apresentando diferentes eficiências relativas de infecção à Pyricularia grisea.

Em virtude dos resultados obtidos, parece claro que um valor único de $\beta$ para cada doença pode ser usado para explicar o efeito da ferrugem, mancha angular e antracnose sobre a eficiência fotossintética de folhas doentes de feijoeiro cv. Rosinha G-2 e cv. Carioca Comum. $O$ fato do valor de $\beta$ não apresentar variações em função de fatores como temperatura e época de avaliação torna mais simples a sua incorporação em modelos de previsão de produção ou de danos. 
Valores de $\beta$ significativamente maiores que 1 (um) são interpretados como uma indicação que a doença não apenas reduziu a área foliar verde, mas também afetou a fotossíntese do tecido foliar verde remanescente (Bastiaans, 1991).

Os valores de $\beta$ reportados para doenças causadas por parasitas obrigados são 1,26 \pm 0,17 para Puccinia recondita f.sp. tritici em trigo (Bastiaans, 1991, baseado nos dados de Spitters et al., 1990), 0,88 $\pm 0,07$ a 2,42 $\pm 0,48$ para Uromyces appendiculatus em feijoeiro (Lopes, 1999) e 8,74 $\pm 1,70$ para Blumeria graminis f.sp. tritici em trigo (Bastiaans, 1991, baseado nos dados de Rabbinge et al., 1990). Valores de $\beta$ reportados para parasitas facultativos são 2,1 \pm 0,61 para Rhynchosporium secalis em cevada (van der Werf et al., 1990, baseado nos dados de Martin, 1986), 2,46 a 2,69 para Phaeosphaeria maydis em milho (Godoy et al., 1998; Godoy et al., 1999), 2,80 $\pm 0,50$ a 3,74 \pm 0,19 para Pyricularia grisea em arroz (Bastiaans, 1991; Bastiaans \& Roumen, 1993), 2,68 \pm 0,22 para Xanthomonas axonopodis pv. phaseoli em feijoeiro (Goodwin, 1992), 11,0 $\pm 3,5$ para as manchas de Cercospora em amendoim (van der Werf et al., 1990, baseado nos dados de Boote et al., 1980), 7,24 $\pm 0,75$ a 18,56 $\pm 2,68$ para Colletotrichum lindemuthianum em feijoeiro (Bassanezi et al., 1997; Lopes, 1999), 12,12 para Mycosphaerella pinodes em ervilha (Garry et al., 1998).

No presente estudo os valores de $\beta$ estimados para ferrugem, mancha angular $\mathrm{e}$ antracnose do feijoeiro ficaram em torno de 2,4 e 8 , respectivamente. Diferenças no modo como estes patógenos se relacionam com o hospedeiro parecem explicar estas diferenças entre os $\beta$ estimados para cada doença.

No caso da ferrugem do feijoeiro, os valores não foram diferentes dos valores anteriormente encontrados por Lopes (1999) e foram similares aos encontrados para a ferrugem da folha do trigo (Spitters et al., 1990), os únicos exemplos de patossistemas envolvendo patógenos causadores de ferrugem. Em outros trabalhos não utilizando a abordagem de Bastiaans (1991), reduções na taxa fotossintética maiores que a esperada pela redução da área verde foram também observadas em folhas de trigo com Puccinia graminis f.sp. tritici (McGrath \& Pennypacker, 1990) e de milho com Puccinia sorghi 
(Shtienberg, 1992). A relação biotrófica de $U$. appendiculatus com as células da folha de feijoeiro causa uma redução na taxa fotossintética mais limitada à área das pústulas com pouca interferência na eficiência com que a radiação interceptada é utilizada pelo restante da folha.

Os efeitos da ferrugem na capacidade fotossintética das folhas do feijoeiro têm sido descritos por vários pesquisadores. Os principais efeitos observados durante a infecção por U. appendiculatus são o aumento da respiração (Bassanezi, 1995; Daly et al., 1961; Livne, 1964; Lopes, 1999; Raggi, 1978; Raggi, 1980) e a perda do conteúdo de clorofila e degradação dos cloroplastos nas áreas das pústulas (Bassanezi, 1995; Livne, 1964; Lopes, 1999; Moll et al., 1995; Peterson \& Aylor, 1995; So \& Thrower, 1976) resultando na redução da eficiência quântica do PSII (Lopes, 1999; Moll et al., 1995; Peterson \& Aylor, 1995) e diminuição da taxa fotossintética líquida da folha infectada (Bassanezi, 1995; Livne, 1964; Lopes, 1999; Raggi, 1978; Raggi, 1980; So \& Thrower, 1976). Nos tecidos verdes remanescentes ao redor das pústulas de $U$. appendiculatus o conteúdo de clorofila geralmente se mantém acima dos níveis encontrados nos tecidos de folhas sadias até o estádio de produção de teliósporos (Stangarlin, 1999; Sziráki et al.; 1984; Wagner \& Boyle, 1995; Wang, 1961) e com a capacidade de transporte de elétrons e geração de ATP e NADPH não afetados (Bassanezi, 1995; Moll et al., 1995; Peterson \& Aylor, 1995; Sziráki et al., 1984; Wang, 1961). Entretanto, nem sempre a redução no conteúdo de clorofila nas regiões das pústulas tem explicado completamente a redução da taxa fotossintética por unidade de área em folhas de feijoeiro com ferrugem, sugerindo uma sutil diminuição na eficiência fotossintética nas áreas ao redor das pústulas (Bassanezi, 1995).

Folhas de feijoeiro com ferrugem apresentam uma melhor capacidade de exportar seus produtos da fotossintese para outras partes da planta (Livne \& Daly, 1966; Zaki \& Durbin, 1965). Associado a isto, tem sido observado o acúmulo de amido nas células ao redor dos sítios de infecção até a fase de esporulação abundante do fungo (Sziráki et al., 1984; Wagner \& Boyle; 1995; Wang, 1961) e um maior conteúdo de sacarose e glicose nos tecidos entre as lesões até o início da esporulação durante a qual 
este conteúdo diminui até níveis iguais aos das folhas não infectadas (Inman, 1962; Wagner \& Boyle; 1995). O aumento da atividade da invertase ácida neste período, observada por Wagner \& Boyle (1995), reverteria, segundo Moerschbacher et al. (1994), o metabolismo primário do hospedeiro, hidrolizando a sacarose em hexoses, que não podem ser exportadas do tecido infectado da folha, mas podem ser absorvidas pelo fungo. Este dreno criado dentro da folha infectada redirecionando o fluxo de assimilados para o fungo e acumulando hexoses inibiriam por realimentação negativa a fotossíntese ao redor das pústulas de ferrugem. Esta redução da fotossíntese estaria relacionada com a menor atividade inicial e total da Rubisco nas regiões entre as pústulas (Stangarlin, 1999).

Quanto aos parasitas facultativos causadores da mancha angular e da antracnose do feijoeiro, os valores de $\beta$ foram significativamente maiores que os encontrados para a ferrugem. Isto implica que, além da redução da área verde fotossintetizante da folha infectada devido às lesões, estes patógenos exercem grande interferência na eficiência com que a radiação interceptada é utilizada pela área foliar remanescente da folha como sugerido e observado previamente por vários pesquisadores (Bassanezi, 1995; Bassanezi et al., 1997; Lopes, 1999; Stangarlin, 1999).

$\mathrm{O}$ valor de $\beta$ obtido para a mancha angular ficou numa faixa intermediária entre os valores relatados para as doenças que causam sintomas de manchas necróticas nas folhas como a escaldadura da cevada, mancha foliar de Phaeosphaeria do milho, brusone do arroz, mancha de Cercospora do amendoim e mancha de Ascochyta da ervilha. Apesar de especulativo, o maior ou menor valor de $\beta$ parece estar associado à definição da área lesionada e à presença e nitidez do halo clorótico ao redor das manchas necróticas. A escaldadura da cevada e a mancha foliar de Phaeosphaeria do milho são doenças que causam sintomas de manchas necróticas com bordos escuros bem nítidos e sem a presença de halos cloróticos ao redor das manchas (Forcelini \& Reis, 1997; Pereira, 1997), sendo sua interferência na eficiência fotossintética da área verde remanescente da folha restrita aos tecidos imediatamente adjacentes às lesões. Na brusone do arroz as manchas também apresentam bordos escuros, mas às vezes as lesões são circundadas por um halo amarelado (Bedendo, 1997), sendo a área de interferência do patógeno pouco 
maior que a área da lesão. As manchas de Cercospora em amendoim podem mostrar halos amarelados nítidos ou não e induzem a abscisão precoce da folha doente (Barreto, 1997; Boote et al., 1980; Bourgeois \& Boote, 1992), enquanto folhas com a mancha de Ascochyta em ervilha apresentam regiões cloróticas mais difusas nos tecidos ao redor das lesões (Salgado, 1980) e prematura desidratação dos tecidos impossível de se distinguir a área verde sadia e a área desidratada verde ou amarela (Garry et al., 1998). Portanto, pode ser esperado um grande efeito destes dois últimos patógenos na eficiência fotossintética das áreas aparentemente sadias das folhas doentes.

A mancha angular do feijoeiro, por sua vez, gera manchas necróticas delimitadas pelas nervuras e regiões cloróticas ao redor das lesões (Bianchini et al., 1997). Quando as lesões atingem por volta de $20-30 \%$ da área foliar causam o amarelecimento e queda prematura da folha (Ferraz, 1980; Godoy, 1995; Mora Brenes, 1983). Folhas com mancha angular apresentam uma redução do conteúdo de clorofila igual ou maior que a severidade de doença, dependendo da cultivar (Bassanezi, 1995; Stangarlin, 1999), mas a redução na assimilação líquida de $\mathrm{CO}_{2}$ mostra-se proporcionalmente maior (Bassanezi, 1995), provavelmente pela redução da atividade inicial e total da Rubisco nas regiões entre as lesões (Stangarlin, 1999). A produção e secreção de compostos tóxicos pelo fungo difusos nas áreas ao redor das lesões, ou a desintegração das células da lesão, impedindo o transporte de água e/ou assimilados e afetando o tecido ao redor das lesões têm sido propostos para explicar esta situação em outros patossistemas envolvendo fungos hemibiotróficos e necrotróficos (Bastiaans, 1991; Boote et al., 1980; Bourgois \& Boote, 1992; Ephrath et al., 1989).

Para a antracnose o valor de $\beta$ obtido foi semelhante aos valores encontrados anteriormente por Bassanezi et al. (1997) e Lopes (1999) em outras condições de avaliação. Diferenças entre alguns valores encontrados por Lopes (1999) e o valor encontrado no presente trabalho podem estar associadas ao método de avaliação da proporção de área doente. Superestimativa ou subestimativa da severidade resultam em valores menores e maiores, respectivamente, de $\beta$. Além da forma irregular das lesões de antracnose, a avaliação da severidade de antracnose é complicada pois é muito dificil 
estabelecer o limiar entre a área verde sadia e a área verde desidratada, como também foi relatado por Garry et al. (1998) na avaliação da severidade da mancha de Ascochyta em ervilha. Também, lesões de mesmo tamanho, mas em diferentes posições na folha podem ter um impacto diferente sobre a fisiologia da folha. Bastiaans \& Roumen (1993) observaram que lesões de brusone localizadas na nervura central de folhas de arroz causaram uma maior redução na taxa fotossintética da parte distal da folha que lesões em regiões distantes da nervura. Neste trabalho, poucos foram os casos em que a nervura central não foi afetada e todas as avaliações incluíram a região da nervura central.

Notavelmente, a antracnose do feijoeiro, com um valor de $\beta$ maior que o da mancha angular, apresenta um efeito maior e diferente sobre a fotossíntese da área verde remanescente. Em tecidos foliares com até $20 \%$ de severidade de antracnose não foi significativa a perda de clorofila (Lopes, 1999), o que é uma indicação de que outro fator é responsável pelas reduções nas taxas fotossintéticas nas folhas doentes. Wong \& Thrower (1978a) observaram uma queda no conteúdo de clorofila em folhas de Vigna sesquipedalis com alta severidade de antracnose, mas eles também observaram que a taxa fotossintética caiu mais rapidamente que o conteúdo de clorofila. O aumento da respiração observado em folhas infectadas por $C$. lindemuthianum é uma das causas apontadas para explicar queda da taxa fotossintética líquida nestas folhas, mas não seria este o principal efeito deste patógeno (Lopes, 1999; Wong \& Thrower, 1978a)

Os sintomas de antracnose em folhas de feijoeiro são caracterizados pela maceração e encharcamento dos tecidos associados com dissolução da parede celular pela ação de pectina liases produzidas pelo patógeno (Wijesundera et al., 1989). Estes sintomas ocorrem preferencialmente sobre as nervuras e pecíolos da folha, provocando o colapso do sistema de feixes vasculares (Schwartz, 1991) e, conseqüentemente, podendo afetar o transporte de água e fotoassimilados pela folha. O tecido adjacente à lesão normalmente torna-se encharcado devido à expulsão de água das células para os espaços intercelulares e depois seca. Em folhas com alta severidade, as regiões encharcadas coalescem rapidamente e grande porção da folha pode secar em menos de um dia após o primeiro sintoma de necrose nas nervuras ser observado. A redução na translocação de 
fotoassimilados poderia resultar no acúmulo de carboidratos que, por sua vez, causa diminuição da taxa de assimilação de $\mathrm{CO}_{2}$ (Neales \& Incoll, 1968), mas segundo Wong \& Thrower (1978b) C. lindemuthiamum não apresentou um efeito significativo na translocação de fotoassimilados em folhas doentes de $V$. sesquipedalis, causando somente um pequeno acúmulo durante os primeiros dias da patogênese. $\mathrm{O}$ impacto maior da doença parece estar associado ao desbalanço hídrico na folha doente. A taxa de transpiração (Bassanezi et al., 1997) e a condutância estomática (Lopes, 1999) reduzem com o aumento da severidade de antracnose. A simultânea redução das taxas de assimilação de $\mathrm{CO}_{2}$ e transpiração são geralmente causadas por dois mecanismos diferentes, um baseado no aumento da resistência à carboxilação e, um segundo, baseado no aumento da resistência estomática, ou melhor na diminuição da condutância estomática que representa o grau de fechamento dos estômatos (Farquar \& Sharkey, 1982). A queda na razão entre a concentração intercelular e a concentração externa de $\mathrm{CO}_{2}$ encontrada por Lopes (1999) indica que o fluxo de $\mathrm{CO}_{2}$ da cavidade subestomática para os sítios de carboxilação é afetado e que o fechamento dos estômatos é a principal causa da redução da assimilação de $\mathrm{CO}_{2}$ neste patossistema.

Em conclusão, estes três patógenos foliares do feijoeiro causam em menor ou maior intensidade uma redução na $R U E$ da folha doente. Este efeito pode ser expresso por um único parâmetro $\beta$ constante sob diversas situações e poderia ser incorporado no cálculo da duração da área foliar sadia (HAD, healthy leaf area duration), da absorção da área foliar sadia (HAA, healthy leaf area absorption) ou em modelos similares para a previsão de produção ou dano nesta cultura, representando acuradamente o efeito destas doenças no crescimento e produtividade do feijoeiro. 


\section{INCORPORAÇÃO DOS EFEITOS DA FERRUGEM, MANCHA ANGULAR E ANTRACNOSE NA EFICIÊNCIA FOTOSSINTÉTICA DE FOLHAS DOENTES DE FEIJOEIRO EM MODELOS DE AVALIAÇÃO DE DANOS}

\subsection{Resumo}

Foi realizada a incorporação dos efeitos da ferrugem, mancha angular e antracnose do feijoeiro na eficiência fotossintética da área verde remanescente das folhas infectadas no cálculo das variáveis área sob a curva de progresso da doença ( $A U D P C)$, duração da área foliar sadia $(H A D)$ e absorção da área foliar sadia $(H A A)$ para o estabelecimento de relações de danos nesta cultura, utilizando os dados originais de experimentos anteriormente conduzidos. Esta incorporação foi feita substituindo-se a proporção de área foliar com sintomas visíveis da doença pela proporção de área foliar na qual a atividade fotossintética é nula (Bastiaans, 1991) pela incorporação dos valores de $\beta$ para ferrugem $(2,173)$, mancha angular $(3,809)$ e antracnose $(7,972)$ no cálculo da severidade de doença.

Feita a substituição, foram calculadas a área abaixo da curva de progresso da doença virtual $(A U V D P C)$, a duração da área foliar fotossintetizante $(P A D)$ e a absorção da área foliar fotossintetizante $(P A A)$. A relações entre a produção e $A U D P C, H A D$, $H A A, A U V D P C, P A D$ e $P A A$ foram examinadas por regressão linear, comparando $A U D P C$ com $A U V D P C, H A D$ com $P A D$ e $H A A$ com $P A A$.

A incorporação do valor de $\beta$ não melhorou a relação entre a área foliar doente fotossinteticamente inativa e a produção, mas melhorou as relações entre a área foliar sadia fotossinteticamente ativa $(P A D$ e $P A A)$ e produção em relação ao uso das variáveis 
$H A D$ e $H A A$, que consideram somente a área foliar verde remanescente. Entretanto, para melhor explicar os efeitos destes três patógenos foliares sobre a produtividade da cultura do feijoeiro, ainda são necessários estudos incluindo a desfolha, os efeitos destes sobre a $R U E$ de folhas sadias de plantas doentes e sobre a partição de fotoassimilados na planta doente.

\subsection{Introdução}

Por causa dos danos causados pelas doenças de plantas foram iniciados os estudos de fitopatologia. Apesar de serem pré-requisitos para a definição de qualquer estratégia ou tática de controle em programas de manejo de doenças (Bergamin Filho et al., 1995; Zadoks \& Schein, 1979), ainda hoje, poucas são as estimativas confiáveis de danos causados por patógenos.

Doenças foliares como a ferrugem, mancha angular e antracnose, pela freqüência de aparecimento e danos causados à produção de grãos, contribuem para a baixa produtividade da cultura do feijoeiro no Brasil (Cardoso et al., 1996; Faria et al., 1996; Menezes \& Menten, 1997; Sartorato et al., 1996).

Estudos que tentaram correlacionar a severidade destas doenças, integralizadas na área abaixo da curva de progresso da doença $(A U D P C$, area under disease progress curve), com a produção na cultura do feijoeiro verificaram que esta é comumente inconsistente (Bergamin Filho et al., 1997; Canteri, 1998; Carneiro et al., 1997; Gianasi, 1999; Iamauti, 1995; Nunes \& Bergamin Filho, 1996; Silva et al.,1998a; Silva et al., 1998b), porque, como apontam Waggoner \& Berger (1987), a produção depende da área sadia, fotossintetizante, das folhas (Monteith \& Elston, 1983; Squire, 1990) e não da área doente, ocupada pelo patógeno.

Waggoner \& Berger (1987) propuseram, então, a substituição da severidade de doença pela duração da área foliar sadia ( $H A D$, healthy leaf area duration) e pela absorção da área foliar sadia (HAA, healthy leaf area absorption) para o prognóstico da produção ou do dano à produção. A partir daí, os conceitos de $H A D$ e $H A A$ têm, até 
então, se mostrado válidos para a avaliação de danos na cultura do feijoeiro atacada por Uromyces appendiculatus (Iamauti, 1995; Silva et al., 1998a), Phaeoisariopsis griseola (Bergamin Filho et al., 1997; Canteri, 1998; Carneiro et al., 1997; Silva et al., 1998a) e Colletotrichum lindemuthianum (Gianasi, 1999; Nunes \& Bergamin Filho, 1996; Silva et al., 1998a).

Entretanto, Johnson (1987), menciona que, para algumas doenças, não só as variáveis $H A D$ e $H A A$, que representam a quantidade de radiação interceptada pela porção verde da planta ( $R I$, radiation interception), são importantes para determinar a produção, mas também a eficiência de conversão ou do uso da radiação (RUE, radiation use efficiency). Para Johnson (1987), a RUE é tão importante quanto $R I$ na determinação da produtividade de uma cultura, sendo essencial a incorporação dos efeitos dos patógenos na eficiência fotossintética das folhas doentes em simuladores e em modelos de crescimento da cultura antes que recomendações baseadas em considerações econômicas possam ser prescritas.

Diante do exposto e do fato destes três patógenos foliares reduzirem a eficiência fotossintética do tecido verde remanescente das folhas infectadas (Capítulo 5), este trabalho teve como objetivo incorporar este efeito no cálculo das variáveis $A U D P C$, $H A D$ e $H A A$ para o estabelecimento de relações de danos na cultura do feijoeiro.

\subsection{Material e Métodos}

Dados originais de experimentos anteriormente conduzidos em campos de feijoeiro com ferrugem (Iamauti, 1995), mancha angular (Carneiro, 1995; Godoy, 1995) e antracnose (Gianasi, 1999) foram utilizados para a incorporação dos efeitos das respectivas doenças na eficiência fotossintética da área verde remanescente das folhas infectadas no cálculo das variáveis $A U D P C, H A D$ e $H A A$ para o estabelecimento de relações de danos na cultura do feijoeiro. 
Informações gerais sobre a instalação dos experimentos realizados para a obtenção da função de dano ocasionado pelas doenças do feijoeiro são mostrados na Tabela 01 .

Tabela 01. Doença, código do experimento, cultivar, safra, data de semeadura, local e referência dos experimentos em cujos dados foram incorporados os efeitos das doenças na eficiência fotossintética da área verde remanescente das folhas infectadas.

\begin{tabular}{c|l|l|l|l|l|l}
\hline Doença & Exp. & \multicolumn{1}{|c}{ Cultivar } & Safra & Semeadura & \multicolumn{1}{c}{ Local } & Referência \\
\hline Ferrugem & F-I & Rosinha G-2 & Inverno & $29 / 05 / 1992$ & Piracicaba-SP & Iamauti, 1995 \\
& F-II & Rosinha G-2 & Inverno & $27 / 05 / 1993$ & Piracicaba-SP & Iamauti, 1995 \\
& & & & & & \\
\hline \multirow{2}{*}{ M. Angular } & M-I & Rosinha G-2 & Inverno & $18 / 05 / 1993$ & Londrina-PR & Carneiro, 1995 \\
& M-II & Carioca Comum & Inverno & $18 / 05 / 1993$ & Londrina-PR & Carneiro, 1995 \\
& M-III & Carioca Comum & Águas & $30 / 08 / 1993$ & Londrina-PR & Carneiro, 1995 \\
& M-IV & Carioca Comum & Seca & $05 / 03 / 1993$ & Piracicaba-SP & Godoy, 1995 \\
& M-V & Rosinha G-2 & Inverno & $14 / 04 / 1994$ & Piracicaba-SP & Godoy, 1995 \\
& & & & & & \\
\hline Antracnose & A-I & Carioca Comum & Inverno & $17 / 05 / 1997$ & Pereiras-SP & Gianasi, 1999 \\
& A-II & Carioca Comum & Inverno & $16 / 06 / 1997$ & Pereiras-SP & Gianasi, 1999 \\
\hline
\end{tabular}

Em todos estes experimentos a metodologia utilizada foi a de plantas individuais (Hau et al., 1980) escolhidas antes das inoculações com os patógenos. A obtenção de diferentes níveis de intensidade de doença foi conseguida por diferentes concentrações de inóculo ou pela aplicação diferenciada de fungicidas pulverizados sobre as plantas. As avaliações foram realizadas a partir do início das inoculações em intervalos médios semanais, anotando-se a área foliar e a severidade da doença de todas as folhas das plantas marcadas e o estádio fenológico da cultura. No final do ciclo da cultura, as plantas marcadas foram colhidas individualmente e a produção medida em gramas por planta.

Informações gerais sobre a epidemia e intensidade de doença ocorrida em cada experimento são mostradas na Tabela 02 . 
Tabela 02. Número de plantas avaliadas ( $n$ ), início da epidemia (dias após o plantio), duração da epidemia (dias), severidade máxima na planta (\%), severidade média nas plantas (\%), AUDPC máxima por dia de epidemia e $A U D P C$ média por dia de epidemia dos experimentos em cujos dados foram incorporados os efeitos das doenças na eficiência fotossintética da área verde remanescente das folhas infectadas.

\begin{tabular}{l|c|c|c|c|c|c|c}
\hline Exp. & $\boldsymbol{n}$ & Início & Duração & Sev. máx. & Sev. méd. & AUDPC máx. & AUDPC méd. \\
\hline F-I & 171 & 47 & 26 & 18,9 & 1,6 & 5,38 & 0,97 \\
F-II & 164 & 39 & 44 & 12,0 & 2,6 & 4,61 & 0,79 \\
& & & & & & & \\
\hline M-I & 92 & 71 & 28 & 12,2 & 2,7 & 4,18 & 0,91 \\
M-II & 88 & 79 & 27 & 6,0 & 0,5 & 1,44 & 0,27 \\
M-III & 93 & 46 & 33 & 3,2 & 0,4 & 1,70 & 0,18 \\
M-IV & 81 & 43 & 24 & 14,4 & 5,0 & 4,72 & 2,04 \\
M-V & 93 & 42 & 22 & 29,5 & 5,3 & 11,85 & 1,91 \\
& & & & & & & \\
\hline A-I & 57 & 46 & 64 & 100,0 & 24,8 & 27,41 & 12,01 \\
A-II & 60 & 51 & 56 & 47,5 & 11,5 & 14,86 & 6,45 \\
\hline
\end{tabular}

A $A U D P C$ para cada planta marcada foi calculada integrando-se a curva de progresso da doença pela eq. (1):

$$
A U D P C=\sum_{i=1}^{n-1}\left[\left(x_{i}+x_{i+1}\right) / 2\right]\left(t_{i+1}-t_{i}\right)
$$

onde, $n$ é o número de avaliações, $x$ é a proporção de área foliar com sintomas visíveis da doença (severidade) no tempo $t_{i}$ e $\left(t_{i+1}-t_{i}\right)$ é o intervalo entre duas avaliações consecutivas.

Os valores do índice de área foliar ( $L A I)$ de cada planta foram estimados dividindo a área foliar de cada planta, em cada avaliação, pela área ocupada por cada planta em função do espaçamento entre plantas na linha e entre linhas. A partir do $L A I$, foram calculadas $H A D$ (dias) e $H A A\left(\mathrm{MJ} \mathrm{m}^{-2}\right.$ ) pelas eq. (2) e (3): 
$H A D=\sum_{i=1}^{n-1}\left\{\left[L A I_{i}\left(1-x_{i}\right)+L A I_{i+1}\left(1-x_{i+1}\right)\right] / 2\right\}\left(t_{i+1}-t_{i}\right)$

$H A A=\sum_{i=1}^{n-1} I_{i}\left(\left\{\left(1-x_{i}\right)\left[1-\exp \left(-k L A I_{i}\right)\right]+\left(1-x_{i+1}\right)\left[1-\exp \left(-k L A I_{i+1}\right)\right]\right\} / 2\right)\left(t_{i+1}-t_{i}\right)$

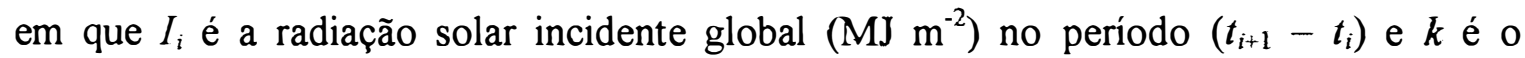
coeficiente de extinção, que para o feijoeiro é estimado como sendo 0,7 (Miglioranza, 1992).

A incorporação do efeito das doenças na eficiência fotossintética da área verde remanescente da folha doente foi feita substituindo em cada folha a proporção de área foliar com sintomas visíveis da doença $(x)$ pela proporção de área foliar com sintomas virtuais da doença $(y)$ na qual a atividade fotossintética é nula (Bastiaans, 1991), obtida pela eq. (4):

$$
y=1-(1-x)^{\beta}
$$

onde o valor de $\beta$ para ferrugem foi 2,173, para mancha angular, 3,809 e, para antracnose, 7,972 (Capítulo 5).

Feita a substituição de $x$ por $y$ nas eq. (1), (2) e (3) foram calculadas a área abaixo da curva de progresso da doença virtual (AUVDPC, area under virtual disease progress curve), a duração da área foliar fotossintetizante (PAD, photosynthetizing leaf area duration), em dias, e a absorção da área foliar fotossintetizante (PAA, photosynthetizing leaf area absorption), em $\mathrm{MJ} \mathrm{m}^{-2}$.

A relações entre a produção e $A U D P C, H A D, H A A, A U V D P C, P A D$ e $P A A$ foram examinadas por regressão linear pelo programa STATISTICA (StatSoft, Tulsa, OK). A comparação entre as variáveis $A U D P C$ e $A U V D P C, H A D$ e $P A D$ e $H A A$ e $P A A$ foi feita pelo coeficiente de determinação da reta de regressão $\left(R^{2}\right)$ entre a variável em questão e a produção e pela análise da distribuição do resíduo. 


\subsection{Resultados}

Os resultados da incorporação do valor de $\beta$ no cálculo das variáveis $A U D P C$, $H A D$ e $H A A$, resultando nas novas variáveis $A U V D P C, P A D$ e $P A A$ respectivamente, estão apresentados na Tabela 03. Os resultados das regressões lineares entre estas variáveis e a produção por planta de feijoeiro são mostradas nas Tabelas 04-06 e, graficamente, nas Figuras 01-09 do Apêndice 4. A distribuição do resíduo (valor observado - valor predito) está representada graficamente em função das variáveis $H A D$, $P A D, H A A$ e $P A A$ nas Figuras 10-18 do Apêndice 4.

Tabela 03. Número de plantas avaliadas ( $n$ ), dias de avaliação, $A U D P C$ e $A U V D P C$ médias por dia de epidemia, $H A D, P A D, H A A$ e $P A A$ médias por dia de avaliação dos experimentos em cujos dados foram incorporados os efeitos das doenças na eficiência fotossintética da área verde remanescente das folhas infectadas.

\begin{tabular}{l|c|c|cc|cc|rr}
\hline Exp. & $\boldsymbol{n}$ & Dias & $\boldsymbol{A U D P C}$ & $\boldsymbol{A U V D P C}$ & $\boldsymbol{H A D}$ & $\boldsymbol{P A D}$ & $\boldsymbol{H A A}$ & $\boldsymbol{P A} \boldsymbol{A}$ \\
\hline F-I & 171 & 26 & 0,97 & $2,05^{*}$ & 3,73 & 3,68 & 10,81 & 10,69 \\
F-II & 164 & 58 & 0,79 & $1,67^{*}$ & 1,78 & 1,77 & 7,10 & 7,05 \\
& & & & & & & & \\
\hline M-I & 92 & 63 & 0,91 & $3,06^{*}$ & 0,81 & 0,80 & 5,12 & 5,07 \\
M-II & 88 & 75 & 0,27 & $0,96^{*}$ & 0,77 & 0,77 & 4,90 & 4,89 \\
M-III & 93 & 56 & 0,18 & $0,62^{*}$ & 0,91 & 0,91 & 7,97 & 7,94 \\
M-IV & 81 & 37 & 2,04 & $7,13^{*}$ & 2,79 & 2,74 & 14,00 & 13,68 \\
M-V & 93 & 36 & 1,91 & $6,62^{*}$ & 5,63 & 5,46 & 14,19 & 13,74 \\
& & & & & & & & \\
\hline A-I & 57 & 71 & 12,01 & $48,25^{*}$ & 2,29 & $1,25^{*}$ & 9,82 & $5,43^{*}$ \\
A-II & 60 & 71 & 6,45 & $34,43^{*}$ & 2,98 & $2,04^{*}$ & 10,90 & $7,83^{*}$ \\
\hline
\end{tabular}

* Difere a $5 \%$ de significância da variável correspondente ao lado esquerdo pelo teste $t$. 
Tabela 04. Ponto de interseção ( \pm erro padrão) e coeficiente angular ( \pm erro padrão) das regressões lineares entre a produção (g/planta) e $A U D P C$ e entre a produção e AUVDPC para plantas de feijoeiro com ferrugem (F), mancha angular (M) ou antracnose (A) em diferentes experimentos.

\begin{tabular}{|c|c|c|c|c|c|}
\hline Experimento & Variável & Interseção & Coef. angular & $\mathbf{R}^{2}$ & $P$ \\
\hline F-I & $A U D P C$ & $17,810 \pm 0,972$ & $-0,002 \pm 2,788$ & 0,000 & 0,937 \\
\hline (Iamauti, 1995) & $A U V D P C$ & $17,857 \pm 0,985$ & $-0,002 \pm 1,343$ & 0,000 & 0,887 \\
\hline F-II & $A U D P C$ & $14,634 \pm 0,624$ & $-0,031 \pm 1,130$ & 0,044 & 0,007 \\
\hline (Iamauti, 1995) & $A U V D P C$ & $14,647 \pm 0,627$ & $-0,015 \pm 0,540$ & 0,044 & 0,007 \\
\hline M-I & $A U D P C$ & $7,854 \pm 0,410$ & $0,004 \pm 0,012$ & 0,001 & 0,752 \\
\hline (Carneiro, 1995) & $A U V D P C$ & $7,805 \pm 0,426$ & $0,002 \pm 0,004$ & 0,002 & 0,655 \\
\hline M-II & $A U D P C$ & $10,404 \pm 0,490$ & $-0,029 \pm 0,045$ & 0,005 & 0,520 \\
\hline (Carneiro, 1995) & $A U V D P C$ & $10,400 \pm 0,501$ & $-0,008 \pm 0,013$ & 0,004 & 0,547 \\
\hline M-III & $A U D P C$ & $11,226 \pm 0,644$ & $0,058 \pm 0,063$ & 0,009 & 0,361 \\
\hline (Carneiro, 1995) & $A U V D P C$ & $10,951 \pm 0,677$ & $0,030 \pm 0,021$ & 0,022 & 0,154 \\
\hline M-IV & $A U D P C$ & $7,660 \pm 0,981$ & $-0,006 \pm 0,017$ & 0,001 & 0,744 \\
\hline (Godoy, 1995) & $A U V D P C$ & $7,826 \pm 1,025$ & $-0,003 \pm 0,005$ & 0,003 & 0,623 \\
\hline M-V & $A U D P C$ & $19,092 \pm 0,802$ & $-0,095 \pm 0,132$ & 0,359 & 0,000 \\
\hline (Godoy, 1995) & $A U V D P C$ & $19,567 \pm 0,828$ & $-0,031 \pm 0,004$ & 0,379 & 0,000 \\
\hline A-I & $A U D P C$ & $33,881 \pm 2,405$ & $-0,020 \pm 0,003$ & 0,501 & 0,000 \\
\hline (Gianasi, 1999) & $A U V D P C$ & $42,525 \pm 3,288$ & $-0,008 \pm 0,001$ & 0,529 & 0,000 \\
\hline A-II & $A U D P C$ & $31,206 \pm 2,143$ & $-0,019 \pm 0,005$ & 0,176 & 0,001 \\
\hline (Gianasi, 1999) & AUVDPC & $31,203 \pm 2,575$ & $-0,003 \pm 0,001$ & 0,121 & 0,006 \\
\hline
\end{tabular}

$\mathrm{R}^{2}=$ coeficiente de determinação.

$P=$ nível de significância. 
Tabela 05. Ponto de interseção ( \pm erro padrão) e coeficiente angular ( \pm erro padrão) das regressões lineares entre a produção (g/planta) e $H A D$ (dias) e entre a produção e $P A D$ (dias) para plantas de feijoeiro com ferrugem $(\mathrm{F})$, mancha angular (M) ou antracnose (A) em diferentes experimentos.

\begin{tabular}{|c|c|c|c|c|c|}
\hline Experimento & Variável & Interseção & Coef. angular & $\mathbf{R}^{2}$ & $P$ \\
\hline F-I & $H A D$ & $-1,197 \pm 0,814$ & $0,196 \pm 0,008$ & 0,790 & 0,000 \\
\hline (Iamauti, 1995) & $P A D$ & $-1,206 \pm 0,811$ & $0,198 \pm 0,008$ & 0,791 & 0,000 \\
\hline F-II & $H A D$ & $1,408 \pm 0,783$ & $0,117 \pm 0,007$ & 0,635 & 0,000 \\
\hline (Iamauti, 1995) & $P A D$ & $1,431 \pm 0,777$ & $0,118 \pm 0,007$ & 0,638 & 0,000 \\
\hline M-I & $H A D$ & $1,930 \pm 0,457$ & $0,118 \pm 0,008$ & 0,685 & 0,000 \\
\hline (Carneiro, 1995) & $P A D$ & $1,890 \pm 0,458$ & $0,120 \pm 0,009$ & 0,687 & 0,000 \\
\hline M-II & $H A D$ & $0,463 \pm 0,731$ & $0,168 \pm 0,012$ & 0,690 & 0,000 \\
\hline (Carneiro, 1995) & $P A D$ & $0,450 \pm 0,730$ & $0,169 \pm 0,012$ & 0,692 & 0,000 \\
\hline M-III & $H A D$ & $0,167 \pm 0,678$ & $0,223 \pm 0,012$ & 0,782 & 0,000 \\
\hline (Carneiro, 1995) & $P A D$ & $0,172 \pm 0,679$ & $0,224 \pm 0,012$ & 0,781 & 0,000 \\
\hline M-IV & $H A D$ & $-1,079 \pm 0,892$ & $0,126 \pm 0,012$ & 0,569 & 0,000 \\
\hline (Godoy, 1995) & $P A D$ & $-1,048 \pm 0,883$ & $0,128 \pm 0,012$ & 0,572 & 0,000 \\
\hline $\mathbf{M}-\mathbf{V}$ & $H A D$ & $3,244 \pm 2,282$ & $0,096 \pm 0,018$ & 0,244 & 0,000 \\
\hline (Godoy, 1995) & $P A D$ & $2,116 \pm 2,191$ & $0,108 \pm 0,018$ & 0,296 & 0,000 \\
\hline A-I & $H A D$ & $-6,646 \pm 1,711$ & $0,153 \pm 0,010$ & 0,822 & 0,000 \\
\hline (Gianasi, 1999) & $P A D$ & $2,029 \pm 0,877$ & $0,183 \pm 0,008$ & 0,904 & 0,000 \\
\hline A-II & $H A D$ & $5,149 \pm 2,554$ & $0,091 \pm 0,012$ & 0,521 & 0,000 \\
\hline (Gianasi, 1999) & $P A D$ & $5,853 \pm 1,856$ & $0,129 \pm 0,012$ & 0,664 & 0,000 \\
\hline
\end{tabular}

$\mathrm{R}^{2}=$ coeficiente de determinação.

$P=$ nível de significância. 
Tabela 06. Ponto de interseção ( \pm erro padrão) e coeficiente angular ( \pm erro padrão) das regressões lineares entre a produção (g/planta) e $H A A\left(\mathrm{MJ} \mathrm{m}^{-2}\right)$ e entre a produção e $P A A\left(\mathrm{MJ} \mathrm{m}^{-2}\right)$ para plantas de feijoeiro com ferrugem (F), mancha angular (M) ou antracnose (A) em diferentes experimentos.

\begin{tabular}{|c|c|c|c|c|c|}
\hline Experimento & Variável & Interseção & Coef. angular & $\mathbf{R}^{2}$ & $P$ \\
\hline F-I & $\boldsymbol{H A A}$ & $-31,090 \pm 3,454$ & $0,174 \pm 0,012$ & 0,546 & 0,000 \\
\hline (Iamauti, 1995) & $P A A$ & $-30,693 \pm 3,448$ & $0,174 \pm 0,012$ & 0,543 & 0,000 \\
\hline F-II & $\boldsymbol{H A A}$ & $-10,373 \pm 1,701$ & $0,058 \pm 0,004$ & 0,559 & 0,000 \\
\hline (Iamauti, 1995) & $P A A$ & $-10,373 \pm 1,175$ & $0,059 \pm 0,004$ & 0,567 & 0,000 \\
\hline M-I & $\boldsymbol{H A A}$ & $-0,642 \pm 0,612$ & $0,027 \pm 0,002$ & 0,700 & 0,000 \\
\hline (Carneiro, 1995) & $P A A$ & $-0,707 \pm 0,614$ & $0,271 \pm 0,002$ & 0,702 & 0,000 \\
\hline M-II & $\boldsymbol{H A A}$ & $-3,732 \pm 1,013$ & $0,038 \pm 0,003$ & 0,696 & 0,000 \\
\hline (Carneiro, 1995) & $P A A$ & $-3,747 \pm 1,010$ & $0,038 \pm 0,003$ & 0,697 & 0,000 \\
\hline M-III & $\boldsymbol{H A} \boldsymbol{A}$ & $-4,514 \pm 1,070$ & $0,036 \pm 0,002$ & 0,727 & 0,000 \\
\hline (Carneiro, 1995) & $P A A$ & $-4,529 \pm 1,072$ & $0,036 \pm 0,002$ & 0,727 & 0,000 \\
\hline M-IV & $\boldsymbol{H A} \boldsymbol{A}$ & $-9,319 \pm 1,775$ & $0,050 \pm 0,005$ & 0,538 & 0,000 \\
\hline (Godoy, 1995) & $P A A$ & $-9,279 \pm 1,756$ & $0,051 \pm 0,005$ & 0,542 & 0,000 \\
\hline $\mathbf{M}-\mathbf{V}$ & $\boldsymbol{H A A}$ & $-31,985 \pm 7,325$ & $0,151 \pm 0,023$ & 0,314 & 0,000 \\
\hline (Godoy, 1995) & $P A A$ & $-35,506 \pm 5,729$ & $0,168 \pm 0,019$ & 0,464 & 0,000 \\
\hline A-I & $\boldsymbol{H A A}$ & $-36,581 \pm 4,949$ & $0,079 \pm 0,007$ & $0, \overline{698}$ & 0,000 \\
\hline (Gianasi, 1999) & $P A A$ & $-6,118 \pm 1,872$ & $0,063 \pm 0,004$ & 0,787 & 0,000 \\
\hline A-II & $\boldsymbol{H A A}$ & $-28,481 \pm 7,923$ & $0,069 \pm 0,010$ & 0,438 & 0,000 \\
\hline (Gianasi, 1999) & $P A A$ & $-3,694 \pm 4,273$ & $0,051 \pm 0,008$ & 0,439 & 0,000 \\
\hline
\end{tabular}

$\mathrm{R}^{2}=$ coeficiente de determinação.

$P=$ nível de significância.

O principal impacto da incorporação do parâmetro $\beta$ foi claramente o aumento da proporção da área considerada doente $(A U V D P C>A U D P C)$. Para os experimentos com ferrugem o aumento médio foi aproximadamente 2,1 vezes, para a mancha angular, em torno de 3,5 vezes e para a antracnose, ao redor de 4,7 vezes (Tabela 03). Este aumento na proporção de área doente, conseqüentemente, levou à redução nas variáveis que medem a área foliar sadia $(P A D<H A D$ e $P A A<H A A)$, entretanto, esta redução só 
foi significativa nos experimentos com antracnose, justamente os experimentos com maiores valores de $A U D P C$ (Tabela 03).

$\mathrm{O}$ efeito da incorporação do $\beta$ nas regressões lineares entre $A U D P C$ e produção e $A U V D P C$ e produção (Tabela 4) não está bem claro. A $A U D P C$ e a $A U V D P C$ não explicaram a produção do feijoeiro em 5 experimentos e nos outros quatro (F-II, M-V, A-I e A-II), em que a regressão linear foi significativa $(P<0,01)$, menos de $53 \%$ da variação dos dados foi explicada pela regressão linear. Outra observação foi que o coeficiente angular das retas de regressão ficou mais próximo do valor zero após a incorporação do $\beta$, mostrando claramente a não correlação entre área doente (não fotossintetizante) e produção nestes patossistemas. Nas regressões entre $A U V D P C \mathrm{e}$ produção foi observado um aumento no erro padrão $(S E)$ do valor estimado para o ponto de interseção uma diminuição do $S E$ do valor estimado do coeficiente angular da reta em todos os casos.

Quanto às regressões lineares entre $H A D$ e produção e $P A D$ e produção, todas foram altamente significativas $(P<0,0001)$ com valores $\mathrm{R}^{2}$ entre 0,52 e 0,90 , exceto no experimento $\mathrm{M}-\mathrm{V}\left(\mathrm{R}^{2}=0,24\right)$, sendo as variações de produção explicadas na sua maior parte pela $H A D$ ou $P A D$ (Tabela 05). A redução da área foliar sadia, refletida numa menor $P A D$ em relação à $H A D$, após a introdução do $\beta$ nos cálculos, aumentou o coeficiente angular destas retas, principalmente quando $H A D$ foi significativamente menor que $P A D$ (A-I e A-II). Na maioria dos casos foram observados menores $S E$ tanto para o ponto de interseção quanto para o coeficiente angular da reta, refletindo num valor de $\mathrm{R}^{2}$ ligeiramente maior nas retas de regressão entre $P A D$ e produção. $\mathrm{O}$ aumento de $\mathrm{R}^{2}$ ocorreu mais nitidamente nos experimentos com maiores $A U D P C$ (M-IV, M-V, A-I e AII). Observou-se, também, uma melhor distribuição dos resíduos quando utiliza-se o valor de $\beta$ para a correção da severidade de doença (Figuras 10-18 do Apêndice 4).

Situação semelhante ocorreu em relação às retas de regressão entre $H A A$ e produção e $P A A$ e produção (Tabela 06). Todas regressões foram altamente significativas $(P<0,0001)$ e $\mathrm{R}^{2}$ entre 0,53 e 0,79 , exceto no experimento $\mathrm{M}-\mathrm{V}\left(\mathrm{R}^{2}=0,31\right)$. Da mesma forma, houve uma tendência de aumento no valor do coeficiente angular das retas de 
regressão entre $P A A$ e produção, exceto nos experimentos com antracnose em que a relação entre $H A A$ e produção apresenta-se de forma exponencial e com a aplicação do valor de $\beta$, a relação $P A A$ e produção passou a ser mais linear. Na maioria dos casos foram observados menores $S E$, refletindo num valor de $\mathrm{R}^{2}$ ligeiramente maior nas retas de regressão entre $P A A$ e produção, principalmente nos experimentos $\mathrm{M}-\mathrm{V}$ e, A-I. Também, foi observada uma melhor distribuição dos resíduos quando utiliza-se o valor de $\beta$ para a correção da severidade de doença (Figuras 10-18 do Apêndice 4).

\subsection{Discussão}

Sendo a produção de uma determinada cultura dependente da capacidade com que as folhas absorvem e utilizam a radiação solar pelo processo da fotossíntese (Monteith \& Elston, 1983; Squire, 1990) a intensidade de doença nesta cultura poderia ser expressa não mais pela proporção de área foliar ocupada pelos sintomas e sim pela proporção de área foliar na qual a ação do patógeno inibe a atividade fotossintética. $\mathrm{O}$ valor de $\beta$ estimado para cada doença permite identificar a proporção da área da folha infectada em que a atividade fotossintética é nula (Bastiaans, 1991), incluindo as lesões necróticas e, muitas vezes, uma área adicional próxima das lesões. A avaliação somente da severidade de doença baseada nos sintomas pode levar à uma subestimativa do efeito da doença na produtividade da cultura e, portanto, o uso do valor $\beta$ permite que se corrija esta severidade em função da atividade fotossintética da folha doente.

Obviamente que a simples correção da avaliação da severidade das folhas doentes não é suficiente para estabelecer a relação doença-dano como demonstrado pela falta de relação entre $A U V D P C$ e produção (Tabela 04). Outros fatores apontados por Waggoner \& Berger (1987) também deveriam ser levados em consideração. A desfolha precoce causada pela doença, principalmente mancha angular e antracnose, deveria ser incorporada à severidade para uma estimativa acurada da intensidade de doença na cultura do feijoeiro (Bergamin Filho et al., 1997; Carneiro et al., 1997; Gianasi, 1999; Silva et al., 1998a; Silva et al., 1998b). Em nenhum dos experimentos utilizados neste 
trabalho foi considerado o efeito da desfolha causada pelo patógeno apesar de ser constatada principalmente nos experimentos com a mancha angular e antracnose (Carneiro, 1995; Gianasi, 1999; Godoy, 1995). A desfolha precoce pode resultar em plantas com igual $A U D P C$, mas com área foliar sadia diferente uma vez que a as folhas caídas devido à desfolha precoce provocada pela doença não são consideradas no cálculo da $A U D P C$ (Carneiro, et al., 1997). Além disso, folhas com mais de $20 \%$ de severidade de mancha angular amarelecem e caem rapidamente no período entre as avaliações, havendo possibilidade de que o cálculo de AUDPC não contabilizasse a quantidade de doença desta folha (Carneiro, 1995). No caso da antracnose, apesar dos sintomas se manifestarem mais rapidamente, a desfolha é um pouco mais demorada e folhas totalmente secas ( $100 \%$ de severidade) permanecem ainda por um certo período na planta, podendo sua severidade ser avaliada e incorporada no cálculo da $A U D P C$ antes de cair (Gianasi, 1999). Além disso, a capacidade compensatória do feijoeiro tem sido mostrada pela capacidade de emitir novas folhas após a desfolha prematura principalmente em plantas de crescimento semi-determinado (Chagas et al., 1979; Galvez et al.; 1977). Níveis pequenos de desfolha até os 20 dias após a emergência resultam em danos menos severos que aqueles quando a desfolha ocorre na fase de floração e enchimento dos grãos (Caballero Grande et al., 1989; Chagas et al., 1979; Galvez et al.; 1977).

As variáveis $H A D$ e $H A A$ preconizadas por Waggoner \& Berger (1987), que levam em consideração a área foliar sadia, podem ter suas relações com a produção de uma cultura melhoradas quando a área sadia passa a ser considerada como a área foliar fotossinteticamente ativa e não somente como a área verde remanescente ou sem lesões necróticas. Nos experimentos em que as severidades de doença foram maiores e as epidemias iniciaram mais cedo, a incorporação do valor de $\beta$ no cálculo de $H A D$ e $H A A$ mostrou significativa melhora na relação destas variáveis com a produção de feijão. A ocorrência tardia (exp. M-I e M-II) e a baixa intensidade das doenças (exp. F-I, F-II, MI, M-II e M-III) explicam porque mesmo corrigindo a intensidade de doença com o valor $\beta$, muito pouco foi melhorado na relação entre as variáveis de área foliar e produção. A 
quantidade de tecido foliar doente alcançada nestes experimentos pode ser considerada irrisória em relação à quantidade de tecido foliar presente nos mesmos, estando abaixo do limiar biológico de dano (Morse \& Buhler, 1997). Outros experimentos semelhantes com maiores severidades de ferrugem e mancha angular deveriam ser conduzidos para a melhor visualização do efeito da incorporação do $\beta$ na relação doença-dano do feijoeiro.

Geralmente, a relação entre $H A D$ e produção é linear na cultura do feijoeiro e a relação entre $H A A$ e produção tem se mostrado, às vezes, linear (Carneiro, 1995) e às vezes exponencial (Godoy, 1995; Gianasi, 1999; Iamauti, 1995), sendo os coeficientes de determinação obtidos para a regressão linear entre $H A A$ e produção sempre menores. A não linearidade entre $H A A$ e produção, observada principalmente nos experimentos com maiores índices de área foliar (F-I, F-II, M-IV, M-V, A-I e A-II), ocorre pela desconsideração das relações fonte-dreno na cultura do feijoeiro. Em plantas de feijoeiro com crescimento semi-determinado ou indeterminado, o uso de $H A A$, considerando-se todas as folhas presentes na planta, pode ocasionar uma superestimativa da relação entre a energia absorvida pela folha e a produção, porque folhas maiores e localizadas na base da planta apresentam taxas fotossintéticas decrescentes e as folhas terminais não totalmente expandidas não translocam seus fotoassimilados para os órgãos reprodutivos (Sache \& Zadoks, 1994). Quando se incorpora o parâmetro $\beta$ no cálculo de $H A A$, parte das mudanças nas translocações de fotoassimilados dentro das folhas doentes, geralmente associadas às reduções na taxa fotossintética da área verde remanescente (Bassanezi, 1997; Livne \& Daily, 1966; Zaki \& Durbin, 1965), já está sendo incluída. Isto poderia explicar a tendência de linearização da relação encontrada entre $P A A$ e produção.

Além da $R I$, a produção de uma determinada cultura também depende da $R U E$ (Johnson, 1987), que pode ser afetada tanto na folha doente como nas folhas sadias de plantas doentes. O efeito dos patógenos sobre a $R U E$ das folhas doentes de feijoeiro já estaria incorporado no valor $\beta$ determinado para cada doença, porém possíveis efeitos de compensação ou mesmo de redução da capacidade fotossintética nas folhas sadias destas plantas doentes não incluídos no valor $\beta$ ainda estariam interferindo com a produção desta planta. Em plantas de feijoeiro, Vigna sesquipedalis ou Vicia faba infectadas com 
Uromyces appendiculatus ou $U$. viciae-fabae, tem sido verificado um efeito compensatório nas folhas não infectadas por um aumento no teor de clorofila, da atividade da Rubisco e da taxa fotossintética (Livne, 1964; Murray \& Walters, 1992; Scholes \& Farrar, 1986; So \& Thrower, 1976; Stangarlin, 1999) dependendo do nível de infecção da folha doente e da cultivar. No caso de Phaeoisariopsis griseola, efeito compensatório foi observado somente na cv. Carioca Comum como um aumento na atividade da Rubisco nas folhas não inoculadas de plantas doentes, enquanto que na cv. Rosinha G-2 houve redução no conteúdo total de clorofila e na atividade da Rubisco nas folhas sadias de plantas doentes (Stangarlin, 1999).

Em suma, o uso do valor de $\beta$ para a correção da severidade das três doenças, resultando nas variáveis $P A D$ e $P A A$, melhorou de certa forma a obtenção de funções de dano na cultura do feijoeiro. Segundo Bastiaans et al. (1994) a determinação dos efeitos de uma doença na fisiologia de folhas individuais é o primeiro passo para o amplo entendimento dos danos causados por esta doença na cultura. Os passos futuros seriam determinar os efeitos da doença na fisiologia da planta toda e, então, integrar esta informação na performance da planta durante toda a estação de cultivo. Desta maneira, estudos envolvendo a desfolha provocada pelos patógenos, os efeitos destes patógenos sobre a $R U E$ de folhas sadias de plantas doentes e a influência destes patógenos na partição dos fotoassimilados na planta doente ainda são necessários para melhor explicar os efeitos destes três patógenos foliares sobre a produtividade desta cultura. 


\section{CONCLUSÕES}

1) Os patógenos foliares estudados causam alterações na fotossíntese, respiração e transpiração nas folhas de feijoeiro a partir do aparecimento dos sintomas das doenças por eles causadas.

2) As mudanças nos mecanismos de regulação dos processos fisiológicos da folha doente de feijoeiro são provocadas, em ordem crescente, por $U$. appendiculatus (biotrófico), P. griseola (hemibiotrófico) e C. lindemuthianum (hemibiotrófico).

3) A taxa fotossintética líquida das folhas de feijoeiro com ferrugem, mancha angular e antracnose é reduzida, tanto pela redução da interceptação da radiação, devido à redução da área foliar verde pelas lesões, como pela redução da eficiência com que a radiação interceptada é utilizada pela área foliar remanescente.

4) A resistência à carboxilação é o principal fator relacionado com a redução da eficiência fotossintética nas áreas aparentemente assintomáticas das folhas com ferrugem e com mancha angular, enquanto que a resistência estomática, aliada à resistência à carboxilação, é o principal fator nas folhas com antracnose.

5) A redução da atividade fotossintética das folhas de feijoeiro em função da severidade de cada doença é quantificada pelo parâmetro $\beta$ do modelo proposto por Bastiaans (1991). Este parâmetro mostra-se constante para cada doença mesmo quando determinado em diferentes épocas de avaliação após a infecção, estádios fenológicos da cultura, temperaturas de desenvolvimento da doença e duas cultivares de feijoeiro.

6) A redução da eficiência de uso da radiação pela folha doente de feijoeiro está associada aos mecanismos pelos quais os patógenos se relacionam com o hospedeiro, sendo maior para a antracnose e menor para a ferrugem. 
7) As variáveis que consideram a área fotossinteticamente ativa, obtida pela incorporação do valor de $\beta$ no cálculo da severidade de doença, explicam melhor as variações na produção de plantas doentes de feijoeiro que as variáveis que consideram somente a área foliar verde remanescente, obtida pela estimativa visual da severidade.

8) Estudos, que considerem a desfolha provocada pelos três patógenos estudados, os efeitos destes patógenos sobre a eficiência do uso da radiação de folhas sadias de plantas doentes e a influência destes patógenos na partição dos fotoassimilados na planta doente, são necessários para melhor explicar os danos causados por estes patógenos na cultura do feijoeiro. 


\section{REFERÊNCIAS BIBLIOGRÁFICAS}

ABO-FOUL, S.; RASKIN, V.I.; SZTEJNBERG, A.; MARDER, J.B. Disruption of chlorophyll and function in powdery mildew-diseased cucumber leaves and its control by the hyperparasite Ampelomyces quisqualis. Phytopathology, v.86, n.2, p. 195-199, 1996.

AGRIOS, G.N. Plant pathology. 4.ed. San Diego: Academic Press, 1997. 635p.

AHMAD, I.; FARRAR, J.F.; WHITBREAD, R. Photosynthesis and chloroplast functioning in leaves of barley infected with brown rust. Physiological Plant Pathology, v.23, n.3, p.411-419, 1983

AHMAD, I.; FARRAR, J.F.; WHITBREAD, R. Membrane integrity in leaves of barley infected by brown rust: an examination using tracer efflux and in vivo chlorophyll fluorescence. New Phytologist, v.99, n.1, p.107-115, 1985

ALMEIDA, A.M.R.; CHAVES, G.M.; ZAMBOLIM, L. Influência da época de ataque de Uromyces phaseoli typica Arth. sobre o rendimento de duas variedades de feijoeiro (Phaseolus vulgaris L.) em casa-de-vegetação. Fitopatologia Brasileira, v.2, p.1721, 1977. 
ALTEN, H. von. The effect of temperature, light and leaf age on the frequency of apressoria formation and infection with Uromyces phaseoli (Pers.) Wint. Journal of Phytopathology, v.107, p.327-335, 1983.

AQUINO, V.M.; SHOKES, F.M.; BERGER, R.D.; GORBET, D.W.; KUCHAREK, T.A. Relationships among late leafspot, healthy leaf area duration, canopy reflectance, and pod yield of peanut. Phytopathology, v.82, n.5, p.546-552, 1992.

AUST, H.J.; BERGAMIN FILHO, A.; MENTEN, J.O.M. Resistance of three bean cultivars to Uromyces phaseoli expressed through sporulation on the fungus. Journal of Phytopathology, v. 110, p.30-36, 1984.

AYRES, P.G. Plants versus pests and pathogens: an old story but the same story? In: AYRES, P.G. (Ed.) Pests and pathogens plant responses to foliar attack. Oxford: Information Press Ltda, 1992. p.1-10.

BACCHI, L.M.A. Quantificação de parâmetros monocíclicos relacionada a epidemias no sistema Uromyces appendiculatus - feijoeiro. Piracicaba, 1993. 99p. Tese (Doutorado) - Escola Superior de Agricultura “Luiz de Queiroz", Universidade de São Paulo.

BARRETO, M. Doenças do amendoim (Arachis hypogeaea L.). In: KIMATI, H.; AMORIM, L.; BERGAMIN FILHO, A.; CAMARGO, L.E.A.; REZENDE, J.A.M. (Ed.) Manual de fitopatologia: doenças das plantas cultivadas. 3.ed. São Paulo: Agronômica Ceres, 1997. v.2, cap.8, p.65-77.

BASSANEZI, R.B. Interações entre o masaico-em-desenho do feijoeiro e duas doenças fúngicas, ferrugem e mancha angular, em plantas de feijoeiro. Piracicaba, 1995. 124p. 
Dissertação (Mestrado) - Escola Superior de Agricultura "Luiz de Queiroz", Universidade de São Paulo.

BASSANEZI, R.B.; MARTINS, M.C.; GODOY, C.V.; AMORIM, L.; BERGAMIN FILHO, A. Efeito da antracnose na eficiência fotossintética do feijoeiro. Fitopatologia Brasileira, v.22, n.4, p.520-524, 1997.

BASTIAANS, L. Ratio between virtual and visual lesion size as a measure to describe reduction in leaf photosynthesis of rice due to leaf blast. Phytopathology, v.81, n.6, p.611-615, 1991 .

BASTIAANS, L. Effects of leaf blast on photosynthesis of rice. 1. Leaf photosynthesis. Netherlands Journal of Plant Pathology, v.99, n.4, p.197-203, 1993.

BASTIAANS, L.; ROUMEN, E.C. Effect on leaf photosynthetic rate by leaf blast for rice cultivars with different types and levels of resistance. Euphytica, v.66, n.1-2, p. 81-87, 1993

BASTIAANS, L.; RABBINGE, R.; ZADOKS, J.C. Understanding and modeling leaf blast effects on crop physiology and yield. In: ZEIGLER, R.S.; LEONG, S.A.; TENG, P.S. (Ed.) Rice blast disease. Wallingford: CAB International, 1994. p.357380 .

BEDENDO, I. P. Doenças do arroz (Oryza sativa L.). In: KIMATI, H.; AMORIM, L.; BERGAMIN FLHO, A.; CAMARGO, L.E.A.; REZENDE, J.A.M. (Ed.) Manual de fitopatologia: doenças das plantas cultivadas. 3.ed. São Paulo: Agronômica Ceres, 1997. v.2, cap. 10, p.85-99. 
BERGAMIN FILHO, A.; CARNEIRO, S.M.T.P.G.; GODOY, C.V.; AMORIM, L.; BERGER, R.D.; HAU, B. Angular leaf spot of Phaseolus beans: relationships between disease, healthy leaf area, and yield. Phytopathology, v.87, n.5, p.506-515, 1997.

BERGAMIN FILHO, A.; LOPES, D.B.; AMORIM, L.; GODOY, C.V.; BERGER, R.D. Avaliação de danos causados por doenças de plantas. Revisão Anual de Patologia de Plantas, v.3, p.133-184, 1995.

BERGHAUS, R.; REISENER, H.J. Changes in photosynthesis of wheat plants infected with wheat stem rust (Puccinia graminis f. sp: tritici). Journal of Phytopathology, v.112, n.2, p. 165-172, 1985.

BERGHAUS, R.; REISENER, H.J.; ARENZ, H.; FRANCK, U.F. Changes in the Hill reaction and the chlorophyll fluorescence of chloroplasts isolated from wheat plants infected with stem rust (Puccinia graminis f. sp. tritici). Journal of Phytopathology, v.118, n.2, p.123-130, 1987.

BEYSCHLAG, W.R.; RYEL, R.J. Modeling leaf/canopy photosynthesis. In: RAGHAVENDRA, A.S. (Ed.) Photosynthesis: a comprehensive treatise. Cambridge: Cambridge University Press, 1998. p.305-319.

BIANCHINI, A. Mosaico dourado do feijoeiro: crescimento do hospedeiro, progresso da doença e produção. Piracicaba, 1998. 95p. Tese (Doutorado) - Escola Superior de Agricultura "Luiz de Queiroz", Universidade de São Paulo.

BIANCHINI, A.; MARINGONI, A.C.; CARNEIRO, S.M.T.P.G. Doenças do feijoeiro (Phaseolus vulgaris L.). In: KIMATI, H.; AMORIM, L.; BERGAMIN FILHO, A.; CAMARGO, L.E.A.; REZENDE, J.A.M. (Ed.) Manual de fitopatologia: doenças 
das plantas cultivadas. 3.ed. São Paulo: Agronômica Ceres, 1997. v.2, cap.34, p.376-399.

BIANCHINI, A.; MENEZES, J.R.; MARINGONI, A.C. Doenças e seu controle. In: INSTITUTO AGRONÔMICO DO PARANÁ. O feijão no Paraná. Londrina, 1989, p.189-216. (IAPAR. Circular, 63).

BOLHÀR-NORDENKAMPF, H.R.; ÖQUIST, G. Chlorophyll fluorescence as a tool in photosynthesis research. In: HALL, D.O; SCURLOCK, J.M.O; BOLHÀRNORDENKAMPF, H.R.; LEEGOOD, R.C.; LONG, S.P. (Ed.) Photosynthesis and production in a changing environment: a field and laboratory manual. London: Chapman \& Hall, 1993. p.193-206.

BOOTE, K.J.; JONES, J.W.; MISHOE, J.W.; BERGER, R.D. Coupling pests to crop growth simulators to predict yield reductions. Phytopathology, v.73, p.1581-1587, 1983.

BOOTE, K.J.; JONES, J.W.; SMERAGE, G.H.; BARFIELD, C.S.; BERGER, R.D. Photosynthesis of peanut canopies as affected by leafspot and artificial defoliation. Agronomy Journal, v.72, n.2, p.247-252, 1980.

BOURGEOIS, G.; BOOTE, K.J. Leaflet and canopy photosynthesis of peanut affected by late leaf spot. Agronomy Journal, v.84, n.3, p.359-366, 1992.

CABALLERO GRANDE, R.; CRUZ, B.; LOK, M.L.C.; HEYER, W. Efectos de la defoliación sobre el rendimento de una variedad de frijol de crescimento indeterminado. Ciencias de la Agricultura, v.36, p.35-40, 1989. 
CAMPBELL, C.L.; MADDEN, L.V. Introduction to plant disease epidemiology. New York: John Wiley \& Sons, 1990. 532p.

CAMPOS, J.A.; ZAK, L.F. Estudio de algunas características de Isariopsis griseola Sacc., agente causal de la mancha angular del frijol. Agrociencia, v.39, p.41-48, 1980

CANTERI, M.G. Uso de medidas da área foliar sadia e refletância no manejo da mancha angular do feijoeiro. Piracicaba, 1998. 81p. Tese (Doutorado) - Escola Superior de Agricultura "Luiz de Queiroz", Universidade de São Paulo.

CANTERI, M.G.; DALlA PRIA, M.; SCHIEBELBEIN, L.M.; SILVA, O.C.; AMORIM, L.; BERGAMIN FILHO, A. Relações entre área foliar sadia, produtividade, refletância e severidade da mancha angular em feijoeiro. Fitopatologia Brasileira, v.23, n.4, p.498-501, 1998.

CARDONA-ALVAREZ, C.; WALKER, J.C. Angular leaf spot of bean. Phytopathology, v.46, p.610-615, 1956.

CARDOSO, J.E.; RAVA, C.A.; SARTORATO, A. Doenças causadas por fungos de solo. In: ARAUJO, R.S.; RAVA, C.A.; STONE, L.F.; ZIMMERMANN, M.J.O. (Coord.) Cultura do feijoeiro comum no Brasil. Piracicaba: POTAFOS, 1996. p.701-722.

CARNEIRO, S.M.T.P.G. Quantificação de danos causados por Phaeoisariopsis griseola em feijoeiro (Phaseolus vulgaris L.) no município de Londrina - PR. Piracicaba, 1995. 102p. Dissertação (Mestrado) - Escola Superior de Agricultura "Luiz de Queiroz", Universidade de São Paulo. 
CARNEIRO, S.M.T.P.G.; AMORIM, L.; BERGAMIN FILHO, A. Avaliação de dano provocado pela mancha angular em feijoeiro: relação entre severidade, área foliar e componentes de produção. Fitopatologia Brasileira, v.22, n.3, p.427-431, 1997.

CARRIJO, I.V.; CHAVES, G.M.; SEDIYAMA, C.S. Análise da resistência de vinte e cinco cultivares de Phaseolus vulgaris L. a Uromyces phaseoli var. typica Arth. Fitopatologia Brasileira, v.4, p.265-279, 1979.

CAYON, S.G.; BELALCAZAR, C.S.; VALENCIA, M.J.A.; ARCILLA, P.M.I. The physiological activity of banana and plantain clones and hybrids and their reaction to black Sigatoka disease. Infomusa, v.5, n.2, p.9-11, 1996. /Resumo em CAB Abstract on CD-ROM, 1997/

CHAGAS, J.M.; VIEIRA, C.; MAESTRI, M.; CARDOSO, A.A. Resposta de duas variedades de feijão (Phaseolus vulgaris L.) ao desfolhamento artificial. Ciência e Cultura, v.31, p.683-687, 1979.

CHARLES-EDWARDS, D.A. Physiological determinants of crop growth. Sydney: Academic Press Australia, 1982.

CHOU, H.M.; ROLFE, S.A.; SCHOLES, J.D. The effect of Albugo candida on the photosynthetic and carbohydrate metabolism of leaves of Arabidopsis thaliana. In: WALTERS, D.R.; SCHOLES, J.D.; BRYSON, R.J.; PAUL, N.D.; McROBERTS, N. (Ed.) Physiological responses of plants to pathogens: aspects of applied biology, 42. Warwick: The Association of Applied Biologists, 1995. p. 149-153.

CODE, J.L.; IRWIN, J.A.G.; BARNES, A. Comparative etiological and epidemiological studies on rust diseases of Phaseolus vulgaris and Macroptilium atropurpureum. Australian Journal of Botany, v.33, p. 147-157, 1985. 
CORNIC, G.; BRIANTAIS, J.M. Partitioning of photosynthetic electron flow between $\mathrm{CO}_{2}$ and $\mathrm{O}_{2}$ reduction in a $\mathrm{C}_{3}$ leaf (Phaseolus vulgaris L.) at different $\mathrm{CO}_{2}$ concentrations and during drought stress. Planta, v.183, p. 178-184, 1991.

CRISPÍN, M.A.; SIFUENTES, J.A.; AVILA, J.C. Enfemedades y plagas del frijol en México. México: INIA, 1976. 42p. (INIA. Folleto de Divulgación, 39).

CRUICKSHANK, I.A.M; RIDER, N.E. Peronospora tabacina in tobbaco: transpiration, growth and related energy considerations. Australian Journal of Biological Sciences, v. 14, p.45-57, 1961.

DAAMEN, R.A.; JORRITSMA, I.T.M. Effects of powdery mildew and weather on winter wheat yield. 2. Effects of mildew epidemics. Netherlands Journal of Plant Pathology, v.96, p.35-46, 1990.

DALLA PRIA, M. Quantificação de parâmetros monocíclicos da antracnose (Colletotrichum lindemuthianum) e da mancha angular (Phaeoisariopsis griseola) do feijoeiro. Piracicaba, 1997. 82p. Tese (Doutorado) - Escola Superior de Agricultura "Luiz de Queiroz", Universidade de São Paulo.

DALLA PRIA, M.; BERGAMIN FILHO, A.; AMORIM, L. Avaliação de diferentes meios de cultura na esporulação de Colletotrichum lindemuthianum, Phaeoisariopsis griseola e Alternaria sp. Summa Phytopathologica, v.23, n.2, p.188-191, 1997.

DALY, J.M. The carbon balance of diseased plants: changes in respiration, photosynthesis and translocation. In: HEITEFUSS, R.; WLLIAMS, P.H. (Ed.) Physiological plant pathology. Berlin: Springer-Verlag, 1976. p.450-479. 
DALY, J.M.; BELL, A.A.; KRUPKA, L.R. Respiratory changes during development of rust diseases. Phytopathology, v.51, p.461-471, 1961.

DIÁZ, P.C.; ARMAS, E.; BARRIOS, A. La mancha angular de la caraota producida por Isariopsis griseola Sacc. en la cuenca del lago de Valencia. Agronomía Tropical, v. 14, p.261-267, 1965.

DUNIWAY, J.M.; DURBIN, R.D. Some effects of Uromyces phaseoli on the transpiration rate and stomatal conductance of beans leaves. Phytopathology, v.61, p.114-119, 1971.

DUNIWAY, J.M.; SLATYER, R.O. Gas exchange studies on the transpiration and photosynthesis of tomato leaves affected by Fusarium oxysporum f.sp. lycopersici. Phytopathology, v.61, n.11, p.1377-1381, 1971.

EPHRATH, J.E.; SHTIENBERG, D.; DRIESHPOUN, J.; DINOOR, A.; MARANI, A. Alternaria alternata in cotton (Gossypium hirsutum) cv. Acala: effects on gas exchange, yield components and yield accumulation. Netherlands Journal of Plant Pathology, v.95, p.157-166, 1989.

ELINGS, A.; ROSSING, W.A.H.; van der WERF, W. Virtual lesion extension: a measure to quantify the effects of bacterial blight on rice leaf $\mathrm{CO}_{2}$ exchange. Phytopathology, v.89, n.9, p.789-795, 1999.

FANCELLI, A.L. Fenologia e exigências climáticas do feijoeiro. In: FANCELLI, A.L. Feijão irrigado. Piracicaba: FEALQ, Departamento de Agricultura, 1990. p.7-24.

FARIA, J.C.; ANJOS, J.R.N.; COSTA, A.F.; SPERÂNDIO, C.A., COSTA, C.L. Doenças causadas por vírus e seu controle. In: ARAUJO, R.S.; RAVA, C.A.; 
STONE, L.F.; ZIMMERMANN, M.J.O. (Coord.) Cultura do feijoeiro comum no Brasil. Piracicaba: POTAFOS, 1996. p.731-769.

FARQUAR, G.D.; SHARKEY, T.D. Stomatal conductance and photosynthesis. Annual Review of Plant Physiology, v.33, p.317-345, 1982.

FARQUAR, G.D.; von CAEMMERER, S. Modeling of photosynthetic response to environmental conditions. In: LANGE, O.L.; NOBEL, P.S.; OSMOND, C.B.; ZIEGLER, H. (Ed.) Physiological plant ecology II. Berlin: Springer-Verlag, 1982. p.549-587.

FARQUAR, G.D.; von CAEMMERER, S.; BERRY, J.A. A biochemical model of photosynthetic $\mathrm{CO}_{2}$ assimilation in leaves of $\mathrm{C} 3$ species. Planta, v. 149, p.78-90, 1980.

FEIJÃO: renda é obstáculo. Globo Rural, v. 169, p.98, nov. 1999.

FERRAZ, S. La mancha foliar angular. In: SCHWARTZ, H.P.; GÁLVEZ, G.E. (Ed.) Problemas de producción del frijol; enfermedades, insectos, limitaciones edáficas y climáticas de Phaseolus vulgaris. Cali: CIAT, 1980. p.55-64.

FORCELINI, C.A.; REIS, E.M. Doenças da cevada (Hordeum vulgare L.). In: KIMATI, H.; AMORIM, L.; BERGAMIN FILHO, A.; CAMARGO, L.E.A.; REZENDE, J.A.M. (Ed.) Manual de fitopatologia: doenças das plantas cultivadas. 3.ed. São Paulo: Agronômica Ceres, 1997. v.2, cap.23, p.251-256.

FOYER, C. Chlorophyll-a fluorescence as a probe for photosynthesis leaf metabolism and plant vitality. In: VARLET-GRANCHER, C.; BONHOMME, R.; SINOQUET, 
H. (Ed.) Crop structure and light microclimate: characterization and applications. Paris: INRA, 1993. p.419-425.

FULTON, N.D.; BOLLENBACHER, K.; TEMPLETON, G.E. A metabolic from Alternaria tenuis that inhibits chlorophyll production. Phytopathology, v.55, n.1, p.49-51, 1965 .

GALLAGHER, J.N.; BISCOE, P.V. Radiation absorption, growth and yield of cereals. Journal of Agricultural Sciences, v.91, p.47-60, 1978.

GALVÃO, M.S.N.; MENTEN, J.O.M. Metodologia de inoculação de Uromyces appendiculatus (Pers.) Ung. em feijoeiro (Phaseolus vulgaris L.) para avaliação de componentes monocíclicos da resistência. Revista de Agricultura, v.62, n.2, p.171$183,1987$.

GALVEZ, G.E.; GALINDO, J.J.; ALVAREZ, G. Defoliación artificial para estimar pérdidas por daños foliares en frijol (Phaseolus vulgaris L.). Turrialba, v.27, p.143146, 1977.

GARRY, G.; JEUFFROY, M.H.; NEY, B.; TIVOLI, B. Effects of Ascochyta blight (Mycosphaerella pinodes) on the photosynthesizing leaf area and the photosynthetic efficiency of the green leaf area of dried-pea (Pisum sativum). Plant Pathology, v.47, p.473-479, 1998.

GAUNT, R.E. A mechanistic approach to yield loss assessment based on crop physiology. In: TENG, P.S. (Ed.) Crop loss assessment and pest management. St. Paul: The American Phytopathological Society, 1987. p.150-159. 
GENTY, B.; BRIANTAIS, J.M.; BAKER, N.R. The relationship between the quantum yield of photosynthetic electron transport and quenching of chlorophyll fluorescence. Biochimica et Biophysica Acta, v.990, p.87-92, 1989.

GIANASI, L. Antracnose do feijoeiro: quantificação de danos e efeito do trifenil acetato de estanho no crescimento do hospedeiro e no progresso da doença. Piracicaba, 1999. 120p. Tese (Doutorado) - Escola Superior de Agricultura "Luiz de Queiroz", Universidade de São Paulo.

GODOY, C.V. Danos causados pela mancha angular em feijoeiro, no município de Piracicaba. Piracicaba, 1995. 72p. Dissertação (Mestrado) - Escola Superior de Agricultura "Luiz de Queiroz", Universidade de São Paulo.

GODOY, C.V.; AMORIM, L.; BERGAMIN FILHO, A. Efeito da mancha de Phaeosphaeria na eficiência fotossintética de plantas de milho. Fitopatologia Brasileira, v.23, p.246, 1998. Suplemento. /Apresentado ao 31. Congresso Brasileiro de Fitopatologia, Fortaleza, 1998 - Resumo/

GODOY, C.V.; CANTERI, M.G.; AMORIM, L.; BERGAMIN FILHO, A. Inibição da fotossíntese e da transpiração em folhas de milho infectadas por Phaeosphaeria maydis. Fitopatologia Brasileira, v.24, p.287, 1999. Suplemento. /Apresentado ao 32. Congresso Brasileiro de Fitopatologia, Curitiba, 1999 - Resumo/

GODOY, C.V.; CARNEIRO, S.M.T.P.G.; IAMAUTI, M.T.; DALLA PRIA, M; AMORIM, L.; BERGER, R.D.; BERGAMIN FILHO, A. Diagrammatic scales for bean diseases: development and validation. Journal of Plant Diseases and Protection, v.104, n.4, p.336-345, 1997. 
GOODMAN, R.N.; KIRÁLY, Z.; WOOD, K.R. The biochemistry and physiology of plant disease. Columbia: University of Missouri Press, 1986. 433p.

GOODWIN, P.H. Effect of common bacterial blight on leaf photosynthesis of bean. Canadian Journal of Plant Pathology, v. 14, p. 203-206, 1992.

GORDON, T.R.; DUNIWAY, J.M. Effects of powdery mildew infection on the efficiency of $\mathrm{CO}_{2}$ fixation and light utilization by sugar beet leaves. Plant Physiology, v. 69, p. 139-142, 1982.

HAIGH, G.R.; CARVER, T.L.W.; GAY, A.P.; FARRAR, J.F. Respiration and photosynthesis in oats exhibiting different levels of partial resistance to Erysiphe graminis D.c. ex Merat f.sp. avenae Marchal. New Phytologist, v.119, p.129-136, 1991.

HALL, D.O.; SCURLOCK, J.M.O.; BOLHÄR-NORDENKAMPF, H.R.; LEEGOOD, R.C.; LONG, S.P. (Ed.) Photosynthesis and production in a changing environment: a field and laboratory manual. London: Chapman \& Hall, 1993 . 477p.

HAMPTON, R.E.; WULLSCHLEGER, S.D.; OOSTERHUIS, D.M. Impact of Verticillium wilt on net photosynthesis, respiration and photorrespiration in fieldgrown cotton (Gossypium hirsutum L.). Physiological and Molecular Plant Pathology, v.37, p.271-280, 1990.

HAU, B.; KRANZ, J.; DENGEL, H.J.; HAMELINK, J. On the development of loss assessment in the tropics. In: TENG, P.S.; KRUPA, S.V. (Ed.) Crop loss assessment. St. Paul: University of Minnesota, 1980. p.254-261. 
HAVERKORT, A.J.; BICAMUMPAKA, M. Correlation between intercepted radiation and yield of potato crops infested by Phytophthora infestans in central Africa. Netherlands Journal of Plant Pathology, v.92, p.239-47, 1986.

HOLLOWAY, P.J.; MACLEAN, D.J.; SCOTT, K.J. Electron transport in thylakoids isolated from barley leaves infected by powdery mildew fungus (Erysiphe graminis DC. ex Merat f.sp. hordei Marchal). New Phytologist, v. 120, p. 145-151, 1992.

HUTCHESON, S.W.; BUCHANAN, B. Bioenergetic and metabolic disturbances in diseased plants. In: CALLOW, J.A. (Ed.) Biochemical plant pathology Chichester: John Wiley, 1983. p.327-345.

IAMAUTI, M.T. Avaliação de danos causados por Uromyces appendiculatus no feijoeiro. Piracicaba, 1995. 85p. Tese (Doutorado) - Escola Superior de Agricultura "Luiz de Queiroz", Universidade de São Paulo.

MMHOFF, M.W.; LEONARD, K.J.; MAIN, C.E. Patterns of bean rust lesion size increase and spore production. Phytopathology, v.72, p.441-446, 1982.

IMHOFF, M.W.; MAIN, C.E.; LEONARD, K.J. Effect of temperature, dew period, and age of leaves, spores, and source pustules on germination of bean rust urediospores. Phytopathology, v.71, p.577-583, 1981.

INGLIS, D.A.; HAGEDORN, D.J. Temperature requirements by Isariopsis griseola for infection and disease development on red kidney beans. Annual Report of Bean Improvement Cooperative, v.28, p.35, 1986.

INMAN, R.E. Disease development, disease intensity, and carbohydrate levels in rusted Pinto bean plants. Phytopathology, v.52, n. 11, p. 1207-1211, 1962. 
ISSA, E.; BASTOS CRUZ, B.P.; WATTANABE, K.; ARRUDA, H.V. Danos produzidos por doenças do feijoeiro Phaseolus vulgaris L. O Biológico, v.46, n.7, p.135-140, 1980.

JANARDHANAN, K.K.; HUSAIN, A. Phytotoxic activity of tenuazonic acid isolated from Alternaria alternata (Fr.) Keissler causing leaf blight of Datura innoxia Mill. and its effect on host metabolism. Journal of Phytopathology, v.111, n.3-4, p.305-311, 1984.

JOHNSON, K.B. Defoliation, disease and growth: a reply. Phytopathology, v.77, n.11, p. 1495-1497, 1987.

JOHNSON, K.B.; TENG, P.S. Coupling a disease progress model for early blight to a model of potato growth. Phytopathology, v.80, p.416-425, 1990.

JOHNSON, K.B.; TENG, P.S.; RADCLIFFE, E.B. Analysis of potato foliage losses caused by interacting infestations of early blight, Verticillium wilt, and potato leafhopper, and the relationship to yield. Journal of Plant Diseases and Protection, v.94, p.22-23, 1987.

KEMPENAAR, C.; HORSTEN, P.J.F.M.; SCHEEPENS, P.C. Effects of Ascochyta caulina on photosynthesis of leaves of Chenopodium album. New Phytologist, v. 132, n.3, p.453-457, 1996.

KOMBRINK, E.; HAHLBROCK, K. Rapid, systemic repression of the synthesis of ribulose-1,5-bisphosphate carboxylase small-subunit mRNA in fungus-infected or elicitor-treated potato leaves. Planta, v.181, p.216-219, 1990. 
KRAUSE, G.H.; WEIS, E. Chlorophyll fluorescence and photosynthesis: the basics. Annual Review of Plant Physilogy and Plant Molecular Biology, v.42, p. 313-349, 1991

LEITE, B.; PASCHOLATI, S.F. Hospedeiro: alterações fisiológicas induzidas por fitopatógenos. In: BERGAMIN FILHO, A.; KIMATI, H.; AMORIM, L. (Ed.) Manual de fitopatologia: princípios e conceitos. 3.ed. São Paulo: Agronômica Ceres, 1995. v.1, cap. 21 , p.393-416.

LEVY, Y.; LEORNARD, K.J. Yield loss in sweet corn in response to defoliation or infection by Exserohilum turcicum. Journal of Phytopathology, v.128, n.2, p.161$171,1990$.

LICHTENTHALER, H.K. Vegetation stress: an introduction to the stress concept in plants. Journal of Plant Physiology, v. 148, p. 4-14, 1996.

LIVNE, A. Photosynthesis in healthy and rust affected plants. Plant Physiology, v.39, p.614-621, 1964.

LIVNE, A.; DALY, J.M. Translocation in healthy and rust-affected beans. Phytopathology, v.56, n.2, p.170-175, 1966.

LLANOS, C.M. Patogenicidad del Isariopsis griseola Sacc. en frijol (Phaseolus vulgaris L.). Acta Agronomica, v.7, p. 165-170, 1957.

LONG, S.P. Leaf gas exchange. In: BARBER, J.; BAKER, N.R. (Ed.). Photosynthetic mechanisms and the environment. New York: Elsevier Science Publishing Co., 1985. p.453-499. 
LONG, S.P.; HÄLLGREN, J.E. Measurement of $\mathrm{CO}_{2}$ assimilation by plants in the field and the laboratory. In: HALL, D.O.; SCURLOCK, J.M.O.; BOLHÄRNORDENKAMPF, H.R.; LEEGOOD, R.C.; LONG, S.P. (Ed.) Photosynthesis and production in a changing environment: a field and laboratory manual. London: Chapman \& Hall, 1993. p.129-167.

LOOMIS, R.S.; ADAMS, S.S. Integrative analysis of host-pathogen relations. Annual Review of Phytopathology, v.21, p.341-362, 1983.

LOOMIS, R.S.; RABBINGE, R.; NG, E. Explanatory models in crop physiology. Annual Review of Plant Physiology, v.30, p.339-367, 1979.

LOPES, D.B. Photosynthetic competence of bean leaves with rust and anthracnose. Gainesville, 1999. 157p. Thesis (Ph.D.) - University of Florida.

LOPES, D.B.; BERGER, R.D.; BERGAMIN FILHO, A. Absorção da área foliar sadia (HAA): uma nova abordagem para a quantificação de dano e para o manejo integrado de doença. Summa Phytopathologica, v.20, p.143-151, 1994.

LUCAS, J.A. Plant pathology and plant pathogens. 3.ed. Oxford: Blackwell Science, 1998. 274p.

LUCAS, N.A.; McKENZIE, B.A.; GAUNT, R.E.; MOOT, D.J. Reduction in radiation interception, radiation use efficiency and photosynthetic rate in field pea (Pisum sativum L.) by Ascochyta diseases. In: INTERNATIONAL CONGRESS OF PLANT PATHOLOGY, 7., Edinburgh, 1998. Offered Papers Abstracts, v.2. Endinburg: BSPP, 1998. Abstract 2.8.13. 
LUTTRELL, E.S. Parasitism of fungi on vascular plants. Mycologia, v.66, n.1, p.1-15, 1974.

MADDEN, L.V. Modeling yield losses at the field scale. In: INTERNATIONAL CONGRESS OF PLANT PATHOLOGY, 6., Montreal, 1993. Abstracts. Montreal: Canadian Phytopathological Society, 1993. p.11.

MADEIRA, A.C.; CLARK, J.A.; ROSSAL, S. Growth, light interception and disease in field bean (Vicia faba): the effect of late infection of Ascochyta fabae. Annals of Applied Biology, v.112, p.585-595, 1988.

MAGYAROSY, A.C.; MALKIN, R. Effect of powdery mildew infection of sugar beet on the content of electron carriers in chloroplasts. Physiological Plant Pathology, v. 13, p. $183-188,1978$

MAGYAROSY, A.C.; SCHÜRMANN, P.; BUCHANAN, B.B. Effect of powdery mildew infection on photosynthesis by leaves and chloroplasts of sugar beets. Plant Physiology, v.57, n.4, p.486-489, 1976.

MARTIN, P.J. Gaseous exchange studies of barley leaves infected with Rhynchosporium secalis (Oudem) J. J. Davis. Physiological and Molecular Plant Pathology, v.28, p.3-14, 1986.

McGRATH, M.T.; PENNYPACKER, S.P. Alteration of physiological processes in wheat flag leaves caused by stem rust and leaf rust. Phytopathology, v.80, n.8, p.677-686, 1990. 
MENDES, B.M.J.; BERGAMIN FILHO, A. Influence of temperature, wetness duration, and leaf type on the quantification of monocyclic parameters of bean rust. Journal of Phytopathology, v. 126, p.183-189, 1989.

MENDES, B.M.J.; BERGAMIN FILHO, A. Período infeccioso e esporulação de Uromyces phaseoli var. typica. Fitopatologia Brasileira, v.15, p.54-57, 1990.

MENEZES, J.R. Manejo integrado das doenças do feijoeiro irrigado. In: SEMINÁRIO SOBRE PRAGAS, DOENÇAS E PLANTAS DANINHAS DO FEIJOEIRO, 5., Piracicaba, 1994. Anais. Piracicaba: FEALQ, 1994. p.112-122.

MENEZES, J.R.; MENTEN, J.O.M. Manejo de doenças na cultura do feijão. In: FANCElli, A.L.; DOURADO NETO, D. (Ed.). Tecnologia da Produção do Feijão Irrigado. Piracicaba: Publique, 1997. p. 140-152.

MIGLIORANZA, E. Modelo matemático-fisiológico para simular o crescimento e a produtividade da cultura do feijão (Phaseolus vulgaris L.). Viçosa, 1992. $184 \mathrm{p}$. Tese (Doutorado) - Universidade Federal de Viçosa.

MIGNUCCI, J.S.; BOYER, J.S. Inhibition of photosynthesis and transpiration in soybean infected by Microsphaera diffusa. Phytopathology, v.69, n.3, p.227-230, 1979

MINARCIC, P.; HERICH, R.; PAULECH, C. Changes of surface membrane and chloroplast ultrastructure of barley, after infection with powdery mildew. Journal of Phytopathology, v.94, p.97-102, 1979. 
MITCHELL, D.T.; FUNG, A.; LEWIS, D.H. Changes in ethanol soluble carbohydrate composition and acid invertase in infected first tissues susceptible to crown rust of oat and wheat stem rust. New Phytologist, v. 80, p.381-392, 1978

MOERSCHBACHER, B.M.; VANDER, P.; SPRINGER, C.; NOLL, U.; SCHMITTMANN, G. Photosynthesis in stem rust-infected, resistant and susceptible near-isogenic wheat leaves. Canadian Journal of Botany, v.72, n.7, p.990-997, 1994.

MOLL, S.; SERRANO, P.; BOYLE, C. In vivo chlorophyll fluorescence in rust-infected bean plants. Angewandte Botanik, v.69, n.5-6, p. 163-168, 1995.

MONTALBINI, P.; BUCHANAN, B.B. Effect of a rust infection on photophosphorylation by isolated chloroplasts. Physiological Plant Pathology, v.4, p.191-196, 1974.

MONTALBINI, P.; BUCHANAN, B.B.; HUTCHENSON, S.W. Effect of rust infection on rates of photochemical polyphenol oxidation and latent polyphenol oxidase activity of Vicia faba chloroplast membranes. Physiological Plant Pathology, v. 18, p.51-57, 1981.

MONTEITH, J.L. Solar radiation and productivity in tropical ecosystems. Journal of Applied Ecology, v.9, p.746-747, 1972.

MONTEITH, J.L. Climate and the efficiency of crop production in Britain. Philosophical Transactions of the Royal Society of London, v.281, p.277-294, 1977. 
MONTEITH, J.L. Does light limit crop production? In: JOHNSON, C.B. (Ed.) Physiological processes limiting plant productivity. London: Butterworths, 1981. cap. 2, p.23-38.

MONTEITH, J.L.; ELSTON, J. Performance and productivity in the field. In: DALE, J.E.; MILTHORPE, F.L. (Ed.) The growth and functioning of leaves. Cambridge: University Press, 1983. p.499-518.

MORA BRENES, B. Estimativa de perdas no rendimento de feijoeiro-comum (Phaseolus vulgaris L.) causadas pela mancha-angular (Isariopsis griseola Sacc.). Viçosa, 1983. 60p. Dissertação (M.S.) - Universidade Federal de Viçosa.

MORDUE, J.E.M. Colletotrichum lindemuthianum. Kew: Commonwelth Mycological Institute, 1971. (Descriptions of Pathogenic Fungi and Bacteria, 316).

MORSE, S.; BUHLER, W. Integrated pest management: ideals and realities in development countries. London: Lynne Rienner Publishers, 1997. 170p.

MOULY, A.; ROBY, D.; ESQUERRÉ-TUGAYÉ, M.T. Ribulose-1,5-bisphosphate carboxylase-oxygenase small subunit transcripts as a susceptibility reflecting molecular marker in sunflower infected with Sclerotinia sclerotiorum. Plant Science, v.56, p. 219-225, 1988.

MURRAY, D.C.; WALTERS, D.R. Increased photosynthesis and resistance to rust infection in upper, uninfected leaves of rusted broad bean (Vicia faba L.). New Phytologist, v.120, p.235-242, 1992.

NAVARRE, D.A.; WOLPERT, T.J. Victorin induction of an apoptotic/senescence-like response in oats. Plant Cell, v. 11, n.2, p.237-249, 1999. 
NEALS, T.F.; INCOLL, L.D. The control of leaf photosynthesis rate by level of assimilate concentration in the leaf: a review of a hypothesis. Botanical Review, v.34, p.107-125, 1968.

NUNES, W.M.C. Avaliação de danos causados pela antracnose (Colletotrichum lindemuthianum (Sacc. \& Magn.) Scribner) do feijoeiro (Phaseolus vulgaris L.). Piracicaba, 1994. 72p. Dissertação (M.S.) - Escola Superior de Agricultura 'Luiz de Queiroz", Universidade de São Paulo.

NUNES, W.M.C; BERGAMIN FILHO, A. Avaliação dos danos causados pela antracnose (Colletotrichum lindemuthianum) do feijoeiro. Fitopatologia Brasileira, v. 21, n. 4, p.436-442, 1996.

O'CONNELL, R.J.; BAILEY, J.A. Hemibiotrophy in Colletotrichum lindemuthianum. In: MENDGEN, K.; LESEMANN, E.D. (Ed.) Electron microscopy of plant pathogens. Berlin: Springer-Verlag, 1991. p.211-222.

O’CONNELL, R.J.; BAILEY, J.A.; RICHMOND, D.V. Cytology and physiology of infection of Phaseolus vulgaris by Colletotrichum lindemuthianum. Physiological and Molecular Plant Pathology, v.27, p.75-98, 1985.

OLAVE, C.A.L. Resistencia de algunas variedades y líneas de frijol (Phaseolus vulgaris L.) al Isariopsis griseola Sacc. Acta Agronomica, v. 8, p.197-219, 1958.

OSMOND, C.B. What is photoinhibition? Some insights from comparisons of shade and sun plants. In: BAKER, N.R.; BOWYER, J.R. (Ed.) Photoinhibition of photosynthesis: from molecular mechanisms to the field. Oxford: BIOS Scientific Publisher, 1994. p. 1-24. 
OWERA, S.A.P.; FARRAR, J.F.; WHITBREAD, R. Growth and photosynthesis in barley infected with brown rust. Physiological Plant Pathology, v.18, n.1, p.79-90, 1981.

OWERA, S.A.P.; FARRAR, J.F.; WHITBREAD, R. Translocation from leaves of barley infected with brown rust. New Phytologist, v.94, p.111-123, 1983.

PARADELLA FILHO, O. Algumas moléstias fúngicas do feijoeiro que ocorrem em São Paulo. In: SIMPÓSIO BRASILEIRO DO FEIJÃO, 1., Campinas, 1971. Anais. Viçosa: Imprensa Universitária, 1972. v.2, p.305-384.

PASCHOLATI, S.F. Fitopatógenos: fitotoxinas e hormônios. In: BERGAMIN FILHO, A.; KIMATI, H.; AMORIM, L. (Ed.) Manual de fitopatologia: princípios e conceitos. 3.ed. São Paulo: Agronômica Ceres, 1995. v.1, cap.20 , p.365-392.

PENNYPACKER, B.W.; KNIEVEL, D.P.; LEATH, K.T.; PELL, E.J.; HILL Jr., R.R. Analysis of photosynthesis in resistant and susceptible alfalfa clones infected with Verticillium albo-atrum. Phytopathology, v.80, n.12, p.1300-1306, 1990.

PEREIRA, O.A.P. Doenças do milho (Zea mays L.). In: KIMATI, H.; AMORIM, L.; BERGAMIN FILHO, A.; CAMARGO, L.E.A.; REZENDE, J.A.M. (Ed.) Manual de fitopatologia: doenças das plantas cultivadas. 3.ed. São Paulo: Agronômica Ceres, 1997. v. 2, cap. 34, p. 538-555.

PETERSON, R.B.; AYLOR, D.E. Chlorophyll fluorescence induction in leaves of Phaseolus vulgaris infected with bean rust (Uromyces appendiculatus). Plant Physiology, v. 108, p. 163-171, 1995. 
PINNSCHMIDT, H.O.; TENG, P.S. Empirical versus mechanistic approaches to adjust yield expectations for multiple pest damage on rice. In: INTERNATIONAL CONGRESS OF PLANT PATHOLOGY, 6., Montreal, 1993. Abstract. Montreal: Canadian Phytopathological Society, 1993. p.116.

PIO-RIBEIRO, G.; CHAVES, G.M. Raças fisiológicas de Colletotrichum lindemuthianum (Sacc. et Magn.) Scrib. que ocorrem em alguns municípios de Minas Gerais, Espírito Santo e Rio de Janeiro. Experientiae, v. 19, p.95-118, 1975.

PORTES, T.A. Ecofisiologia. In: ARAUJO, R.S.; RAVA, C.A.; STONE, L.F.; ZIMMERMANN, M.J.O. (Coord.) Cultura do feijoeiro comum no Brasil. Piracicaba: POTAFOS, 1996. p.101-137.

PRING, R.J. A fine-structural study of the infection of leaves of Phaseolus vulgaris by uredospores of Uromyces phaseoli. Physiological Plant Pathology, v.17, p.269-276, 1980.

RABBINGE, R.; JORRITSMA, I.T.M.; SCHANS, J. Damage components of powdery mildew in winter wheat. Netherlands Journal of Plant Pathology, v.91, n.5, p.235247,1985 .

RAGGI, $\mathrm{V}$. The $\mathrm{CO}_{2}$ compensation point, photosynthesis and respiration in rust infected bean leaves. Physiological Plant Pathology, v.13, p. 135-139, 1978.

RAGGI, V. Correlation of $\mathrm{CO}_{2}$ compensation point $(\Gamma)$ with photosynthesis and respiration and $\mathrm{CO}_{2}$-sensitive $\Gamma$ in rust-affected bean leaves. Physiological Plant Pathology, v.16, n. 1, p.19-24, 1980. 
RAGGI, V. $\mathrm{CO}_{2}$ assimilation, respiration and chlorophyll fluorescence in peach leaves infected by Taphrina deformans. Physiologia Plantarum, v.93, p.540-544, 1995.

RASMUSSEN, J.B.; SCHEFFER, R.P. Effects of selective toxin from Helminthosporium carbonum on chlorophyll synthesis in maize. Physiological and Molecular Plant Pathology, v.32, p.283-291, 1988.

RAVA, C.A.; SARTORATO, A. Antracnose. In: SARTORATO, A.; RAVA, C.A. (Ed.) Principais doenças do feijoeiro comum e seu controle. Brasília: EMBRAPA/CNPAF, 1994. p.17-39. (EMBRAPA/CNPAF. Documentos, 50).

RAVA, C.A.; SARTORATO, A.; CARVALHO, J.R.P. Yield losses in dry bean (Phaseolus vulgaris L.) caused by angular leaf spot (Isariopsis griseola Sacc.). Annual Report of Bean Improvement Cooperative, v.28, p.5-6, 1985.

RIOS, G.P. Ferrugem. In: SARTORATO, A.; RAVA, C.A., (Ed.) Principais doenças do feijoeiro comum e seu controle. Brasília: EMBRAPA/CNPAF, 1994. p.69-84. (EMBRAPA/CNPAF. Documentos, 50).

ROBERTS, A.M.; WALTERS, D.R. Photosynthesis in discrete regions of leek leaves infected with the rust, Puccinia allii Rud. New Phytologist, v.110, n.3, p.371-376, 1988.

ROTEM, J.; BASHI, E; KRANZ, J. Studies of crop loss in potato late blight caused by Phytophthora infestans. Plant Pathology, v.32, p.117-122, 1983a.

ROTEM, J.; KRANZ, J.; BASHI, E. Measurement of healthy and diseased haulm area for assessing late blight epidemics in potatoes. Plant Pathology, v.32, p.109-115, $1983 b$. 
SACHE, I.; ZADOKS, C. Effect of rust (Uromyces viciae-fabae) on yield components of faba bean. Plant Pathology, v.44, p.675-685, 1994.

SAETTLER, A.W. Angular leaf spot. In: HALL, R (Ed.) Compendium of bean diseases. St. Paul: APS Press, 1991. p.15-16.

SALGADO, C.L. Doenças d a ervilha - Pisum sativum L. In: GALLI, F. (Coord.) Manual de fitopatologia: doenças das plantas cultivadas. 2.ed. São Paulo: Agronômica Ceres, 1980. v.2, cap. 17, p.270-274.

SAlisBurY, F.B.; ROSS, C.W. Plant Physiology. Belmont: Wadsworth, 1992. $682 \mathrm{p}$.

SANTOS, I.C.F.; ALMEIDA, A.A.F.; VALLE, R.R. Chlorophyll fluorescence parameters characterizing the development of two cacao genotypes infected by witches broom. Photosynthetica, v.35, n. 1, p. 29-39, 1998.

SARTORATO, A. Resistência vertical e horizontal do feijoeiro comum (Phaseolus vulgaris L.) a Isariopsis griseola Sacc. Piracicaba, 1989. 131 p. Tese (Doutorado) Escola Superior de Agricultura "Luiz de Queiroz", Universidade de São Paulo.

SARTORATO, A. Principais doenças da parte aérea do feijoeiro comum e seus controles. In: FANCELLI, A.L. Feijão irrigado. Piracicaba: FEALQ, Departamento de Agricultura, 1990. p.71-85.

SARTORATO, A.; RAVA, C.A. Influência da cultivar e do número de inoculações na severidade da mancha angular (Isariopsis griseola) e nas perdas na produção do 
feijoeiro comum (Phaseolus vulgaris). Fitopatologia Brasileira, v.17, p.247-251, 1992.

SARTORATO, A.; RAVA, C.A. Mancha angular. In: SARTORATO, A.; RAVA, C.A. (Ed.) Principais doenças do feijoeiro comum e seu controle. Brasília: EMBRAPA/CNPAF, 1994. p.41-68. (EMBRAPA/CNPAF. Documentos, 50).

SARTORATO, A.; RAVA, C.A.; RIOS, G.P. Doenças fúngicas e bacterianas da parte aérea. In: ARAUJO, R.S.; RAVA, C.A.; STONE, L.F.; ZIMMERMANN, M.J.O. (Coord.) Cultura do feijoeiro comum no Brasil. Piracicaba: POTAFOS, 1996. p.669-700.

SCHEIN, R.D. Some effects of temperature during the colonization period of bean rust. Phytopathology, v.51, p.674-680, 1961.

SCHNABEL, G.; STRITTMATTER, G.; NOGA, G. Changes in photosynthetic electron transport in potato cultivars with different field resistance after infection with Phytophthora infestans. Journal of Phytopathology, v. 146, p.205-210, 1998.

SCHOLES, J.D. Photosynthesis: cellular and tissue aspects in diseased leaves. In: AYRES, P.G. (Ed.) Pest and pathogens: plant responses to foliar attack. Oxford: BIOS Scientific Publisher, 1992. p.85-106.

SCHOLES, J.D.; FARRAR J.F. Photosynthesis and chloroplast functioning within individual pustules of Uromyces muscari on bluebell leaves. Physiological Plant Pathology, v.27, n. 3, p.387-400, 1985.

SCHOLES, J.D.; FARRAR J.F. Increased rates of photosynthesis in localized regions of a barley leaf infected with brown rust. New Phytologist, v. 104, n.4, p.601-612, 1986. 
SCHOLES, J.D.; FARRAR, J.F. Development of symptoms of brown rust of barley in relation to the distribution of fungal mycelium, starch accumulation and localized changes in the concentration of chlorophyll. New Phytologist, v.107, p.103-117, 1987.

SCHOLES, J.D.; LEE, P.J.; HORTON, P.; LEWIS, D.H. Photosynthetic metabolism in leaves infected with powdery mildew. In: BALTSCHEFFSKY, M. (Ed.). Current research in photosynthesis. Dordrecht: Kluwer, v.4, 1990. p.219-222.

SCHOLES, J.D.; LEE, P.J.; HORTON, P.; LEWIS, D.H. Invertase: understanding changes in the photosynthetic and carbohydrate metabolism of barley leaves infected with powdery mildew. New Phytologist, v. 126, n.2, p.213-222, 1994.

SCHOLES, J.D.; ROLFE, S.A. How do biotrophic pathogens affect the photosynthetic metabolism of their hosts? In: WALTERS, D.R.; SCHOLES, J.D.; BRYSON, R.J.; PAUL, N.D.; McROBERTS, N. (Ed.) Physiological responses of plants to pathogens: aspects of applied biology. Warwick: The Association of Applied Biologists, 1995. p.91-99.

SCHOLES, J.D.; ROLFE, S.A. Photosynthesis in localized regions of oat leaves infected with crown rust (Puccinia coronata): quantitative imaging of chlorophyll fluorescence. Planta, v. 199, n. 4, p.573-582, 1996.

SCHREIBER, U.; SCHLIWA, U.; BILGER, W. Continuous recording of photochemical and non-photochemical chlorophyll fluorescence quenching with a new type of modulation fluorometer. Photosynthesis Research, v.10, p.51-62, 1986. 
SCHWARTZ, H.F. Anthracnose. In: HALL, R. (Ed.) Compendium of bean diseases. St. Paul: APS Press, 1991. p. 16-17.

SHAH, S.F.; GAUNT, R.E.; McKENZIE, B.A.; FRAMPTON, C.M. Reduction in radiation interception (RI) and radiation use efficiency (RUE) in potatoes infected by Alternaria solani. In: INTERNATIONAL CONGRESS OF PLANT PATHOLOGY, 7., Edinburgh, 1998. Offered Papers Abstracts, v.2. Endinburg: BSPP, 1998. Abstract 2.8.10.

SHAW, M. The physiology and host-parasite relations of the rusts. Annual Review of Phytopathology, v. 1, p.259-294, 1963.

SHTIENBERG, D. Effects of foliar diseases on gas exchange processes: a comparative study. Phytopathology, v.82, n.7, p.760-765, 1992.

SILVA, M.B.; VALE, F.X.R.; ZAMBOLIM, L.; HAU, B. Efeitos da ferrugem, da antracnose e da mancha angular na área foliar de plantas de feijoeiro em condições de campo. Fitopatologia Brasileira, v.23, n.4, p.442-447, 1998a.

SILVA, M.B.; VALE, F.X.R.; ZAMBOLIM, L.; HAU, B.; BERGAMIN FILHO, A. Relação entre severidade de doença, área foliar sadia, absorção da área foliar sadia e produção na cultura do feijoeiro. Summa Phytopathologica, v.24, n.3/4, p.226-231, 1998b.

SINDHAN, G.S.; BOSE, S.K. Perpetuation of Phaeoisariopsis griseola causing angular leaf spot of french bean. Indian Phytopathology, v.32, p.252-254, 1979. 
SMEDEGAARD-PETERSEN, V. The role of respiration and energy generation in diseased and disease-resistant plants. In: WOOD, R.K.S.; JELLIS, J.G. (Ed.) Plant diseases: infection, damage and loss. Oxford: Blackwell Scientific, 1984. p.73-85.

SO, M.L.; THROWER, L.B. The host-parasite relationship between Vigna sesquipedalis and Uromyces appendiculatus. I. Development of parasitic colonies and the pattern of photosynthesis. Journal of Phytopathology, v. 85, n. 4, p.320-332, 1976.

SPITTERS, C.J.T.; van ROERMUND, H.J.W.; van NASSAU, H.G.M.G.; SCHEPERS, J.; MESDAG, J. Genetic variation in partial resistance to leaf rust in winter wheat: disease progress, foliage senescence and yield reduction. Netherlands Journal of Plant Pathology, v.96, n. 1, p.3-15, 1990.

SQUIRE, G.R. The physiology of tropical crop production. Wallingford: CAB International, 1990. $236 \mathrm{p}$.

STANGARLIN, J.R. Atividades de ribulose-1,5-bifosfato carboxilase (Rubisco), clorofilase, $\beta$-1,3-glucanase e quitinase e conteúdo de clorofila em cultivares de feijoeiro (Phaseolus vulgaris) infectados com Uromyces appendiculatus ou Phaeoisariopsis griseola. Piracicaba, 1999. 119p. Tese (Doutorado) - Escola Superior de Agricultura “Luiz de Queiroz", Universidade de São Paulo.

STAPLES, R.C. The development of infection structures by the rusts and other fungi. Microbiological Sciences, v.2, n.7, p.193-198, 1985.

STATLER, G.D. Apparent photosynthesis in healthy and Puccinia recondita infected wheat plants. Canadian Journal of Plant Pathology, v. 10, p.203-206, 1988. 
STAVELY, J.R. Rust. In: HALL, R. (Ed.) Compendium of bean diseases. St. Paul: APS Press, 1991. p.24-25.

SZIRÁKI, I.; MUSTÁRDY, L.A.; FALUDI-DÁNIEL, Á.; KIRÁLY, Z. Alterations in chloroplast ultrastructure and chlorophyll content in rust-infected Pinto Beans at different stages of disease development. Phytopathology, v.74, n.1, p.77-84, 1984.

TANG, X.; ROLFE, S.A.; SCHOLES, J.D. The effect of Albugo candida (white blister rust) on the photosynthetic and carbohydrate metabolism of leaves of Arabidopsis thaliana. Plant, Cell and Environment, v. 19, n. 8, p.967-975, 1996.

TARABRIN, G.A. Energy efficiency of wheat photosynthesis with helminthosporiosis infection. Russian Agricultural Sciences, n.9, p.22-25, 1995. /Resumo em CAB Abstracts on CD-ROM, 1996-98/07/

TARABRIN, G.A.; BYSTRYKH, E.E. Activity of primary photosynthetic reactions as a test in breeding wheat for resistance to Helminthosporium root rot. Sel'skokhozyaisvennaya-Biologiya, n.5, 59-69, 1990. /Resumo em CAB Abstracts on CD-ROM, 1990-91/

TU, J.C. Effect of temperature on incidence and severity of anthracnose on white bean. Plant Disease, v.66, n.9, p.781-783, 1982.

TU, J.C. Colletotrichum lindemuthianum on bean: population dynamics of the pathogen and breeding for resistance. In: BAILEY, J.A.; JEGER, M.J. (Ed.) Colletotrichum: biology, pathology and control. Wallingford: CAB, 1992. p.388.

van der WERF; BASTIAANS, L.; ROSSING, W.A.H.; RABBINGE, R. Modeling crop response to growth reducing factors. In: INTERNATIONAL SYMPOSIUM ON 
BIOTIC STRESS OF BARLEY IN ARID AND SEMI-ARID ENVIRONMENTS, Bozeman, 1990. Proceedings. Bozeman: Montana State University, 1990. p.87-102..

van KOOTEN, O.; SNEL, J.F.H. The use of chlorophyll fluorescence nomenclature in plant stress physiology. Photosynthesis Research, v.25, p. 147-150, 1990.

van OIJEN, M. Photosynthesis is not impaired in healthy tissue of blighted potato plants. Netherlands Journal of Plant Pathology, v.96, n.2, p. 55-63, 1990.

van SCHOONHOVEN, A.; PASTOR-CORRALES, M.A. Sistema estándar para la evaluación de germoplasma de frijol. Cali: CIAT, 1987. 56p.

VARGAS, E. La Roya. In: SCHWARTZ, H.F.; GÁlVEZ, G.E. (Ed.) Problemas de produccion del frijol: enfermedades, insectos, limitaciones edáficas y climáticas de Phaseolus vulgaris. Cali: CIAT, 1980. p. 17-36.

VIEIRA, C. Doenças e pragas do feijoeiro. Viçosa: UFV, 1983. 231p.

WAGGONER, P.E.; BERGER, R.D. Defoliation, disease and growth. Phytopathology, v.77, n.3, p.393-398, 1987.

WAGNER, S.; BOYLE, C. Changes in carbohydrate, protein and chlorophyll content, and enzyme activity during switch from uredinio- to teliospore sporulation in the beanrust fungus Uromyces appendiculatus (Pers.) Link. Journal of Phytopathology, v. 143, p.633-638, 1995.

WALTERS, D.R.; AYRES, P.G. Ribulose bisphosphate carboxylase protein and enzymes of $\mathrm{CO}_{2}$ assimilation in barley infected by powdery mildew (Erysiphe graminis hordei). Journal of Phytopathology, v.109, p.208-218, 1984. 
WANG, D. The nature of starch accumulation at the rust infection site in leaves of Pinto bean plants. Canadian Journal of Botany, v.39, p. 1595-1604, 1961.

WATSON, D.J. Comparative physiological studies on the growth of field crops. I. Variation in net assimilation rate and leaf area between species and varieties, and within and between years. Annals of Botany, v.11, p.41-76, 1947.

WATSON, D.J. The physiological basis of variation in yield. Advances in Agronomy, v.4, p.101-145, 1952.

WIJESUNDERA, R.L.C.; BAILEY, J.A.; BYRDE, R.J.W.; FIELDING, A.H. Cell wall degrading enzymes of Colletotrichum lindemuthianum: their role in the development of bean anthracnose. Physiological and Molecular Plant Pathology, v.34, p.403413,1989

WONG, P.Y.O.; THROWER, L.B. Effect of Colletotrichum lindemuthiamum on photosynthesis and respiration of Vigna sesquipedalis. Journal of Plant Pathology, v.92, p.88-94, 1978a.

WONG, P.Y.O.; THROWER, L.B. Sugar metabolism and translocation in Vigna sesquipedalis infected by Colletotrichum lindemuthianum. Journal of Plant Pathology, v.92, p.102-112, 1978b.

WOODROW, I.E.; BERRY, J.A. Enzymatic regulation of photosynthetic $\mathrm{CO}_{2}$ fixation in $\mathrm{C}_{3}$ plants. Annual Review of Plant Physiology and Plant Molecular Biology, v.39, p.533-594, 1988. 
WRIGHT, D.P.; BALDWIN, B.C.; SHEPHARD, M.C.; SCHOLES, J.D. Source-sink relationships in wheat leaves infected with powdery mildew. I Alterations in carbohydrate metabolism. Physiological and Molecular Plant Pathology, v.47, n.4, p. 237-253, 1995a.

WRIGHT, D.P.; BALDWIN, B.C.; SHEPHARD, M.C.; SCHOLES, J.D. Source-sink relationships in wheat leaves infected with powdery mildew. II Changes in the regulation of the Calvin cycle. Physiological and Molecular Plant Pathology, v.47, n.4, p. 255-267, $1995 b$.

YARWOOD, C.E. Uredospore production by Uromyces phaseoli. Phytopathology, v. 51, p. $22-27,1961$.

YOKOYAMA, L.P.; BANNO, K.; KLUTHCOUSKI, J. Aspectos socioeconômicos da cultura. In: ARAUJO, R.S.; RAVA, C.A.; STONE, L.F.; ZIMMERMANN, M.J.O (Coord.) Cultura do feijoeiro comum no Brasil. Piracicaba: POTAFOS, 1996. p. 1-21.

YURINA, T.P.; KARAVAEV, V.A.; SOLNTSEV, M.K. Characteristics of metabolism in two cucumber cultivars with different resistance to powdery mildew. Russian Plant Physiology, v.40, n.2, p. 197-202, 1993.

YURINA, T.P.; YURINA, E.V.; KARAVAEV, V.A.; SOLNTSEV, M.K.; KUKUSHKINA, M.A.; EKOBENA, F.A.P. Physiological characteristics of wheat leaves in cultivars resistant and susceptible to powdery mildew. Russian Journal of Plant Physiology, v.43, n. 1, p.64-69, 1996.

ZADOKS, J.C.; SCHEIN, R.D. Epidemiology and plant disease management. New York: Oxford University Press, 1979. 427p. 
ZAKI, A.I.; DURBIN, R.D. The effect of bean rust on the translocation of photosynthetic products from diseased leaves. Phytopathology, v.55, n.5, p.528-529, 1965.

ZAMBOLIM, L.; CHAVES, G.M.; MARTINS, M.C. del P. Aspectos das principais doenças do feijão no Estado de Minas Gerais. Informe Agropecuário, v.8, n.90, p.20-29, 1982.

ZAUMEYER, W.J.; THOMAS, H.R. A monographic study of bean diseases and methods for their control. Washington: USDA, 1957. 255p. (USDA. Technical Bulletin, 868).

ZITKO, S.E.; STATLER, G.D.; NUTTER Jr., F.W. Chlorophyll of wheat leaves with differences in leaf rust severity and reaction type. Canadian Journal of Phytopathology, v.7, n.2, p.146-150, 1985. 
APÊNDICES 


\section{APÊNDICE 1}

\section{DETERMINAÇÃO DA SATURAÇÃO LUMÍNICA EM PLANTAS DE FEIJOEIRO CULTIVADAS EM CÂMARA DE CRESCIMENTO.}

Um teste preliminar foi realizado para o estabelecimento de um protocolo para a avaliação das trocas gasosas em folhas de feijoeiro cultivadas sob condições de câmara de crescimento (Conviron, modelo E-7) de forma a permitir uma avaliação acurada e rápida com o aparelho LI-6400 Portable Photosynthesis System.

Para este teste, sementes da cv. Carioca Comum foram semeadas em vasos de alumínio com capacidade para 2 litros de substrato (terra: areia: esterco de curral). Logo após a germinação, deixou-se duas plântulas por vaso e estes foram transferidos para as câmaras de crescimento, onde foram submetidas à temperatura de $25^{\circ} \mathrm{C}$ constante e 14 horas de fotoperíodo a $150 \mu \mathrm{mol} \mathrm{m}^{-2} \mathrm{~s}^{-1}$ (PAR). Após 30 dias, quando as primeiras folhas trifolioladas estavam bem expandidas, foram realizadas as avaliações da taxa fotossintética líquida, condutância estomática e taxa de transpiração utilizando as seguintes condições experimentais:

-Temperatura da folha dentro da câmara de análise: $25^{\circ} \mathrm{C}$

-Fluxo de ar pela câmara de análise: $500 \mu \mathrm{mol} \mathrm{s}^{-1}$

-Umidade relativa na câmara de análise: 70 a $80 \%$

-Diferencial de pressão de vapor d'água na superfície foliar: 0,573 a 0,813

-Concentração de $\mathrm{CO}_{2}$ no ar entrando na câmara de análise: 356,0 a 367,1 ppm

-Fonte de luz: 6400-02 LED light source (comprimento de onda de 660 a $675 \mathrm{~nm}$ )

-Razão estomática: 0,25

As curvas da taxa fotossintética líquida, condutância estomática e taxa de transpiração em função da intensidade de irradiação foram obtidas utilizando-se as condições padrões variando-se a intensidade de irradiação (em $\left.\mu \mathrm{mol} \mathrm{m} \mathrm{m}^{-2} \mathrm{~s}^{-1}, \mathrm{PAR}\right)$ a cada 10 a 15 minutos na seguinte seqüência: $150,100,75,50,150,250,400,600$ e 150, para 
a planta $1,150,100,50,150,250,400,600$ e 150 , para a planta 2 , e $150,100,50,150$, 300 e 450 , para a planta 3.

Os resultados obtidos (Figura 01) mostraram pouca variação na taxa fotossintética líquida, condutância estomática e taxa de transpiração para medições repetidas na mesma intensidade de irradiação $\left(150 \mu \mathrm{mol} \mathrm{m} \mathrm{m}^{-2} \mathrm{~s}^{-1}\right)$. Além disso, praticamente não houve diferença entre as três plantas avaliadas, mostrando que as condições de crescimento possibilitaram uma baixa variação entre as repetições. Quanto menor for a variação entre as plantas, mais fácil será identificar as variações causadas pela infecção com os patógenos.

A taxa fotossintética líquida aumentou com o aumento da intensidade de irradiação, mas a partir de $400 \mu \mathrm{mol} \mathrm{m}^{-2} \mathrm{~s}^{-1}$ ela permaneceu praticamente constante (Figura 01a), mostrando ser este o ponto de saturação lumínica para as plantas de feijoeiro crescidas nas condições de câmara de crescimento.

A condutância estomática e a transpiração das folhas mostraram-se positivamente relacionadas com a intensidade de irradiação, aumentando ou permanecendo constante a medida que aumentava-se a intensidade de irradiação (Figuras 01b e 01c). Estes resultados mostraram que os estômatos não estão fechando durante a avaliação e estão respondendo adequadamente às mudanças da intensidade de irradiação, provando ser o ambiente de crescimento das plantas adequado para a realização dos experimentos. 

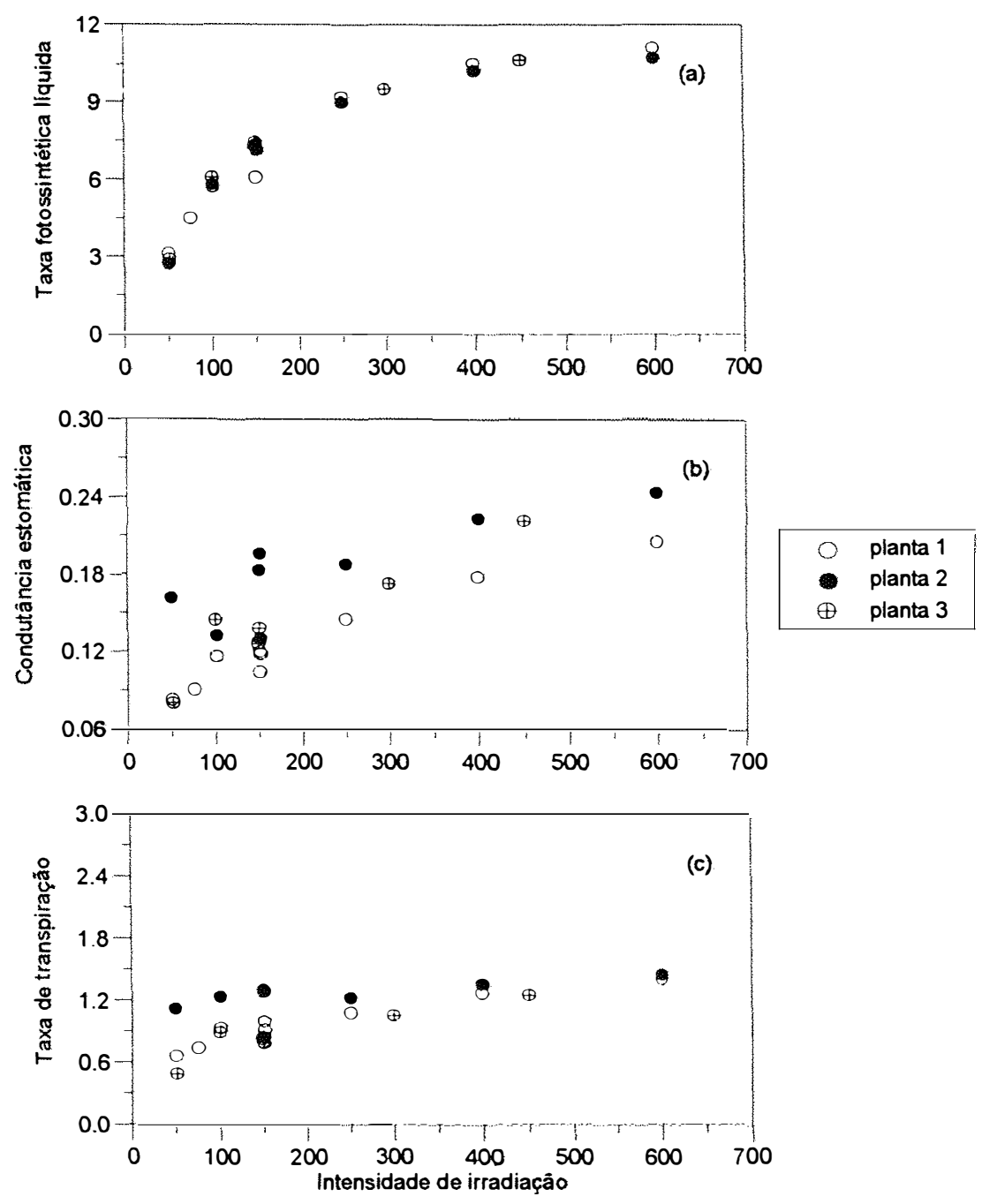

Figura 01. Taxa fotossintética (a), em $\mu \mathrm{mol} \mathrm{CO} \mathrm{CO}^{-2} \mathrm{~s}^{-1}$, condutância estomática (b), em mol $\mathrm{H}_{2} \mathrm{O} \mathrm{m}^{-2} \mathrm{~s}^{-1}$, e taxa de transpiração (c), em mmol $\mathrm{H}_{2} \mathrm{O} \mathrm{m}^{-2} \mathrm{~s}^{-1}$, em função da intensidade de irradiação (PAR), em $\mu \mathrm{mol} \mathrm{m} \mathrm{m}^{-2} \mathrm{~s}^{-1}$, obtida de plantas de Carioca Comum crescidas em condições de câmara de crescimento. 


\section{APÊNDICE 2}

\section{DETERMINAÇÃO DA RAZÃO ESTOMÁTICA EM FOLHAS DE DUAS CULTIVARES DE FEIJOEIRO COMUM.}

A razão estomática expressa a razão do número de estômatos presentes na face adaxial (superior) da folha pelo número de estômatos presentes na face abaxial (inferior) da folha. Para o cálculo correto dos valores de condutância estomática, taxa fotossintética e transpiração, é necessário que no início do uso do equipamento $L I-6400$ Portable Photosynthesis System seja fornecido o valor correto da razão estomática. Para plantas com folhas puramente anfiestomáticas deve entrar com o valor 1 e para folhas hipoestomáticas com o valor 0

No caso das folhas de feijoeiro, dados da literatura (Hall et al., 1993) mostravam que o feijoeiro, de maneira geral, possuía uma folha hipoestomática, tendo de 8-16 estômatos $/ \mathrm{mm}^{2}$ na face superior e 132-184 estômatos $/ \mathrm{mm}^{2}$ na face inferior. Utilizando-se as médias destes valores chega-se a uma razão estomática de 0,076 .

Entretanto, julgou-se necessário determinar a razão estomática para as duas cultivares de feijoeiro que seriam empregadas nos experimentos deste trabalho (Carioca Comum e Rosinha G-2). Para tanto, foram coletadas as primeiras e segundas folhas trifolioladas de plantas crescidas em câmara de crescimento e em casa-de-vegetação de ambas cultivares. Metade da folha na face superior e a metade oposta na face inferior receberam verniz para a obtenção da impressão da superficie foliar na película de verniz formada. Após a secagem, com o auxílio de uma pinça de ponta fina, retirou-se cuidadosamente a película de verniz sem que fosse retidos pedaços da cutícula foliar. As películas foram, então, colocadas em uma lâmina de microscopia e fixadas com uma lamínula presa com uma fita adesiva. As lâminas foram identificadas com o nome da cultivar e face foliar correspondente. Ao final, foram contados o número de estômatos presentes em cada campo do microscópio óptico (área de $0,159 \mathrm{~mm}^{2}$ ). Foram contados 
os estômatos de 8 folhas de cada cultivar, contando-se de 45 a 75 campos do microscópio por face foliar.

Os resultados encontrados mostraram uma significativa diferença em relação aos dados da literatura. A razão em ambas cultivares foi significativamente maior que a citada por Hall et al. (1993). A cultivar Rosinha G-2 teve 31-52 estômatos $/ \mathrm{mm}^{2}$ na face superior e 135-232 estômatos/ $/ \mathrm{mm}^{2}$ na face inferior, tendo uma razão estomática média de 0,269. Já a cultivar Carioca Comum teve 30-72 estômatos $/ \mathrm{mm}^{2}$ na face superior e 147-259 estômatos $/ \mathrm{mm}^{2}$ na face inferior, possuindo uma razão estomática média de 0,243 . Desta forma, optou-se usar um valor médio de 0,25 nas avaliações das variáveis fotossintéticas para ambas as cultivares. 
APÊNDICE 3

FIGURAS DA TAXA FOTOSSINTÉTICA LÍQUIDA RELATIVA EM FUNÇÃO DA SEVERIDADE DE DOENÇA NOS EXPERIMENTOS EM CÂMARA DE CRESCIMENTO E EM CAMPO 

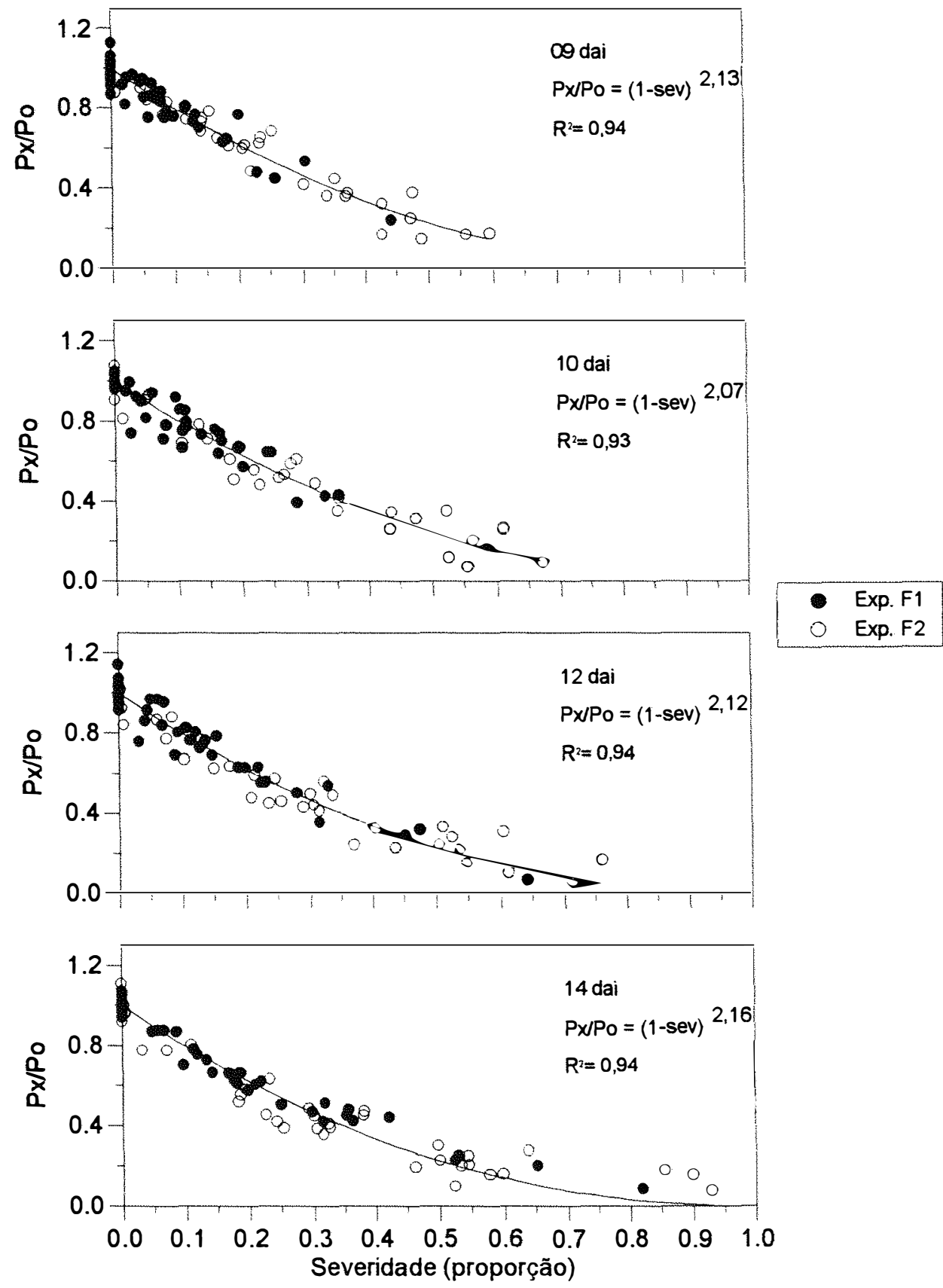

Figura 01. Relação entre a taxa fotossintética líquida relativa e a severidade de ferrugem em folíolos de feijoeiro cv. Rosinha G-2 crescidos a $15^{\circ} \mathrm{C}$ aos $9,10,12$ e 14 dias após a inoculação 

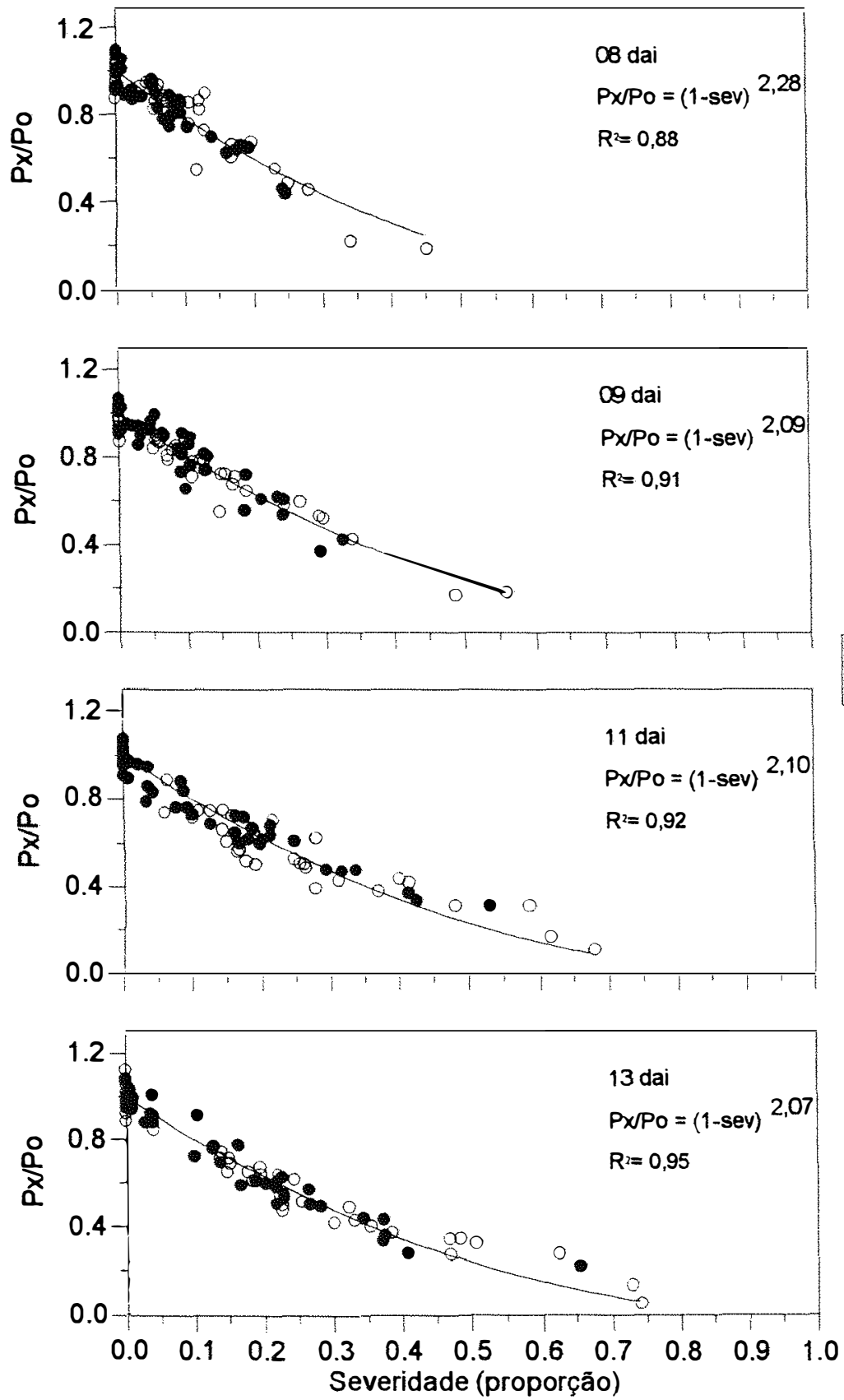

Figura 02. Relação entre a taxa fotossintética líquida relativa e a severidade de ferrugem em folíolos de feijoeiro cv. Rosinha G-2 crescidos a $19^{\circ} \mathrm{C}$ aos $8,9,11$ e 13 dias após a inoculação. 

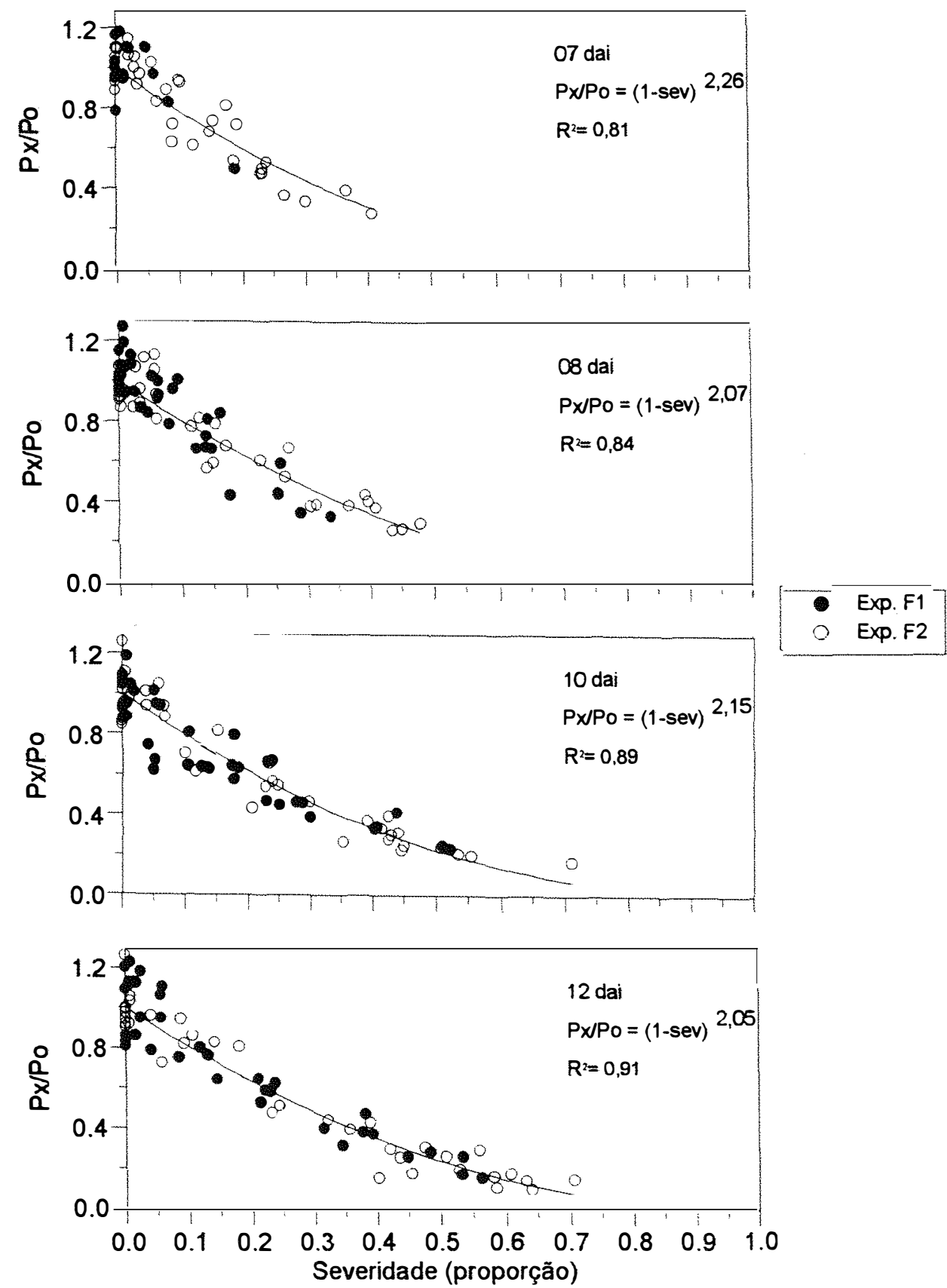

Figura 03. Relação entre a taxa fotossintética líquida relativa e a severidade de ferrugem em folíolos de feijoeiro cv. Rosinha G-2 crescidos a $23{ }^{\circ} \mathrm{C}$ aos $7,8,10$ e 12 dias após a inoculação. 

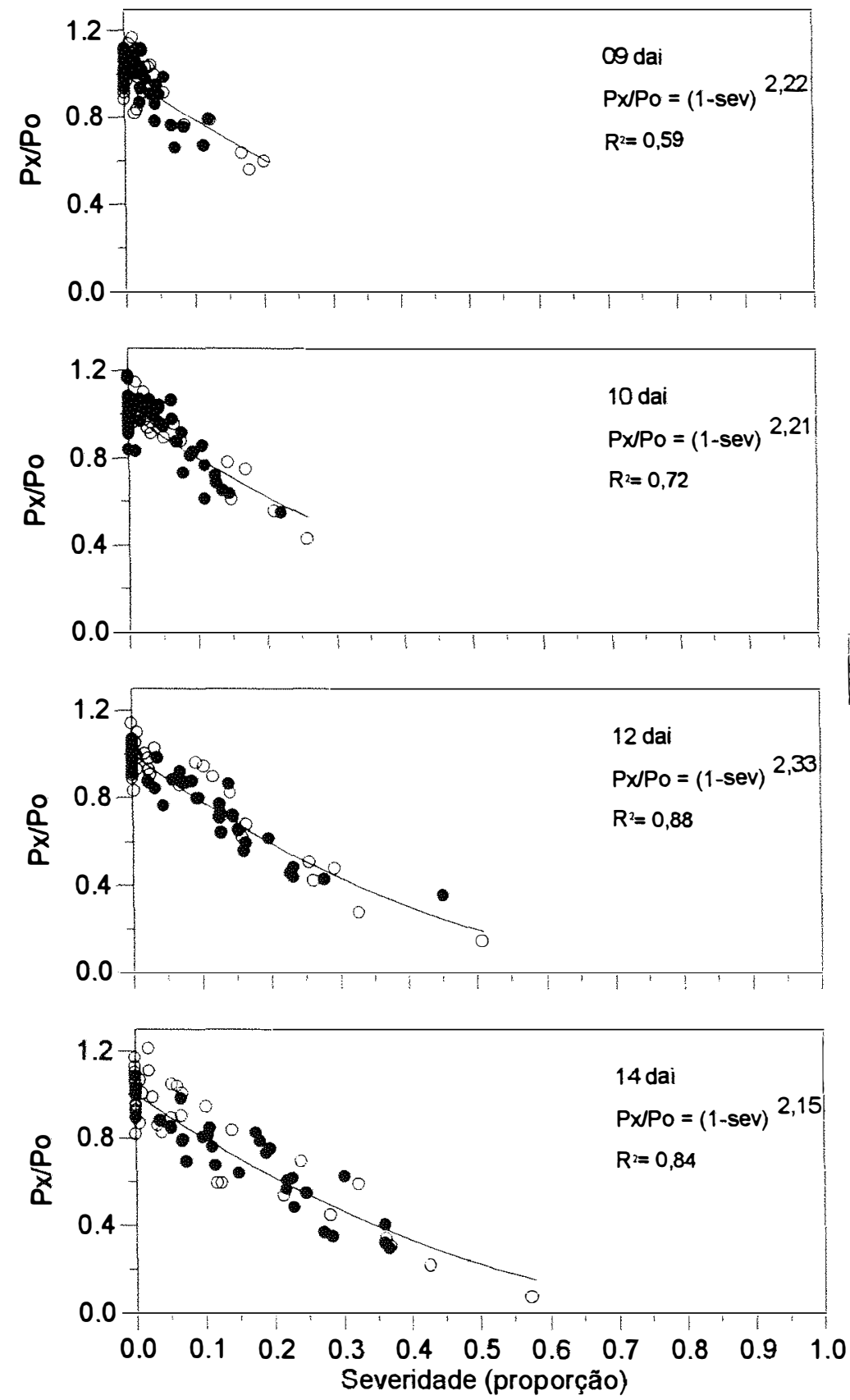

Figura 04. Relação entre a taxa fotossintética líquida relativa e a severidade de ferrugem em folíolos de feijoeiro cv. Carioca Comum crescidos a $15^{\circ} \mathrm{C}$ aos $9,10,12 \mathrm{e}$ 14 dias após a inoculação. 

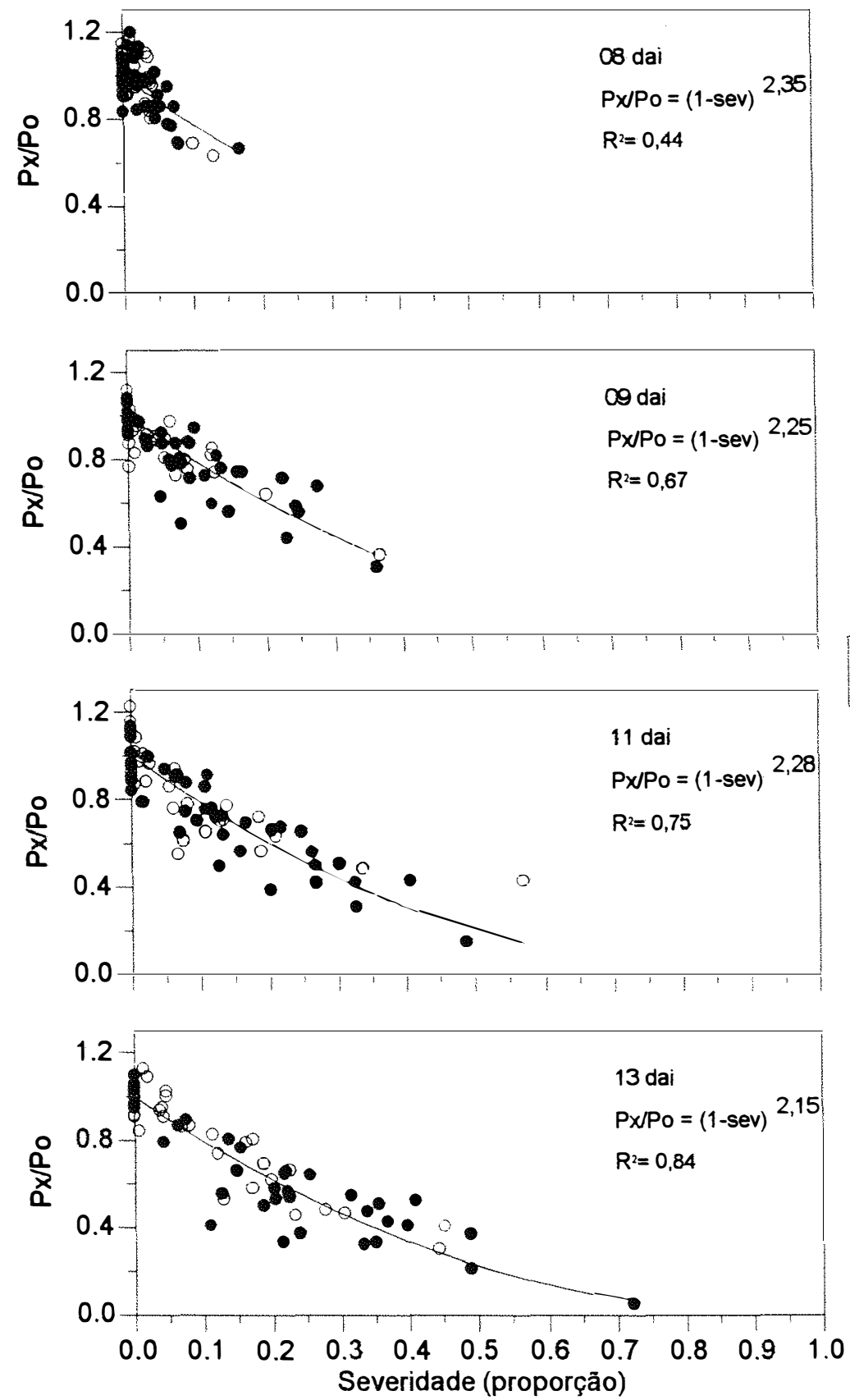

Figura 05. Relação entre a taxa fotossintética líquida relativa e a severidade de ferrugem em folíolos de feijoeiro cv. Carioca Comum crescidos a $19^{\circ} \mathrm{C}$ aos $8,9,11$ e 13 dias após a inoculação. 

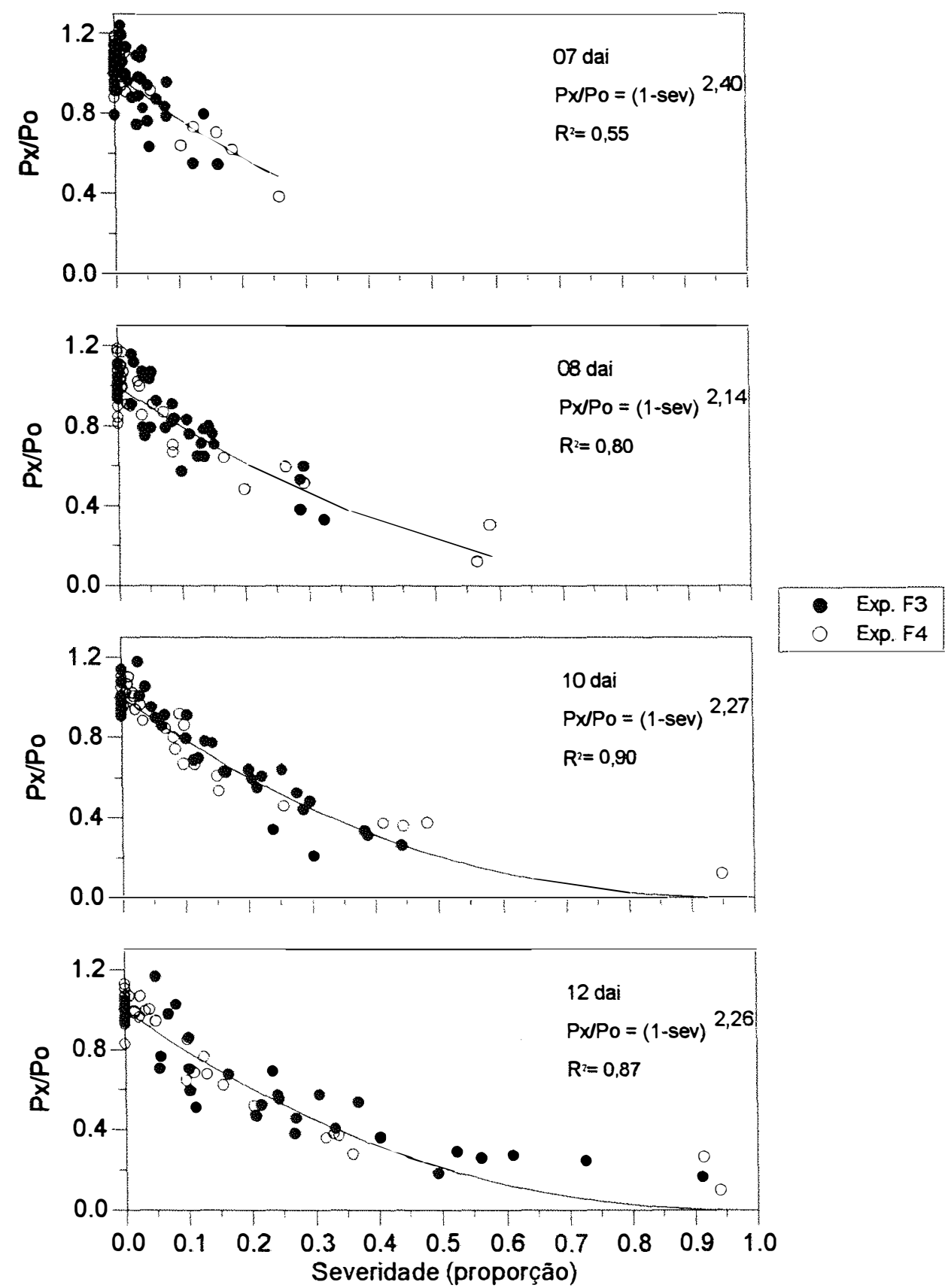

Figura 06. Relação entre a taxa fotossintética líquida relativa e a severidade de ferrugem em folíolos de feijoeiro cv. Carioca Comum crescidos a $23{ }^{\circ} \mathrm{C}$ aos $7,8,10$ e 12 dias após a inoculação. 

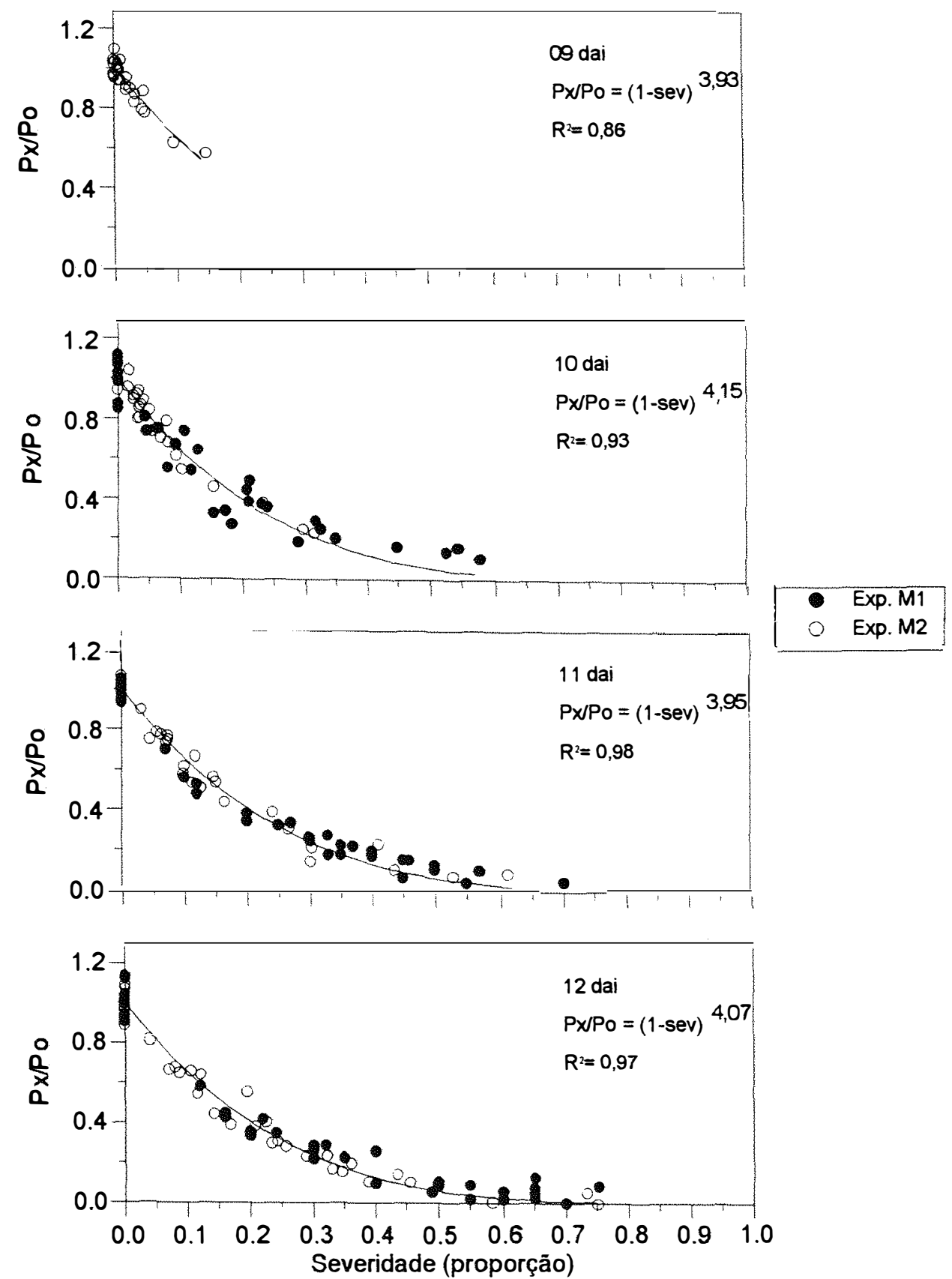

Figura 07. Relação entre a taxa fotossintética líquida relativa e a severidade de mancha angular em folíolos de feijoeiro cv. Rosinha G-2 crescidos a $19^{\circ} \mathrm{C}$ aos 9,10 , 11 e 12 dias após a inoculação. 

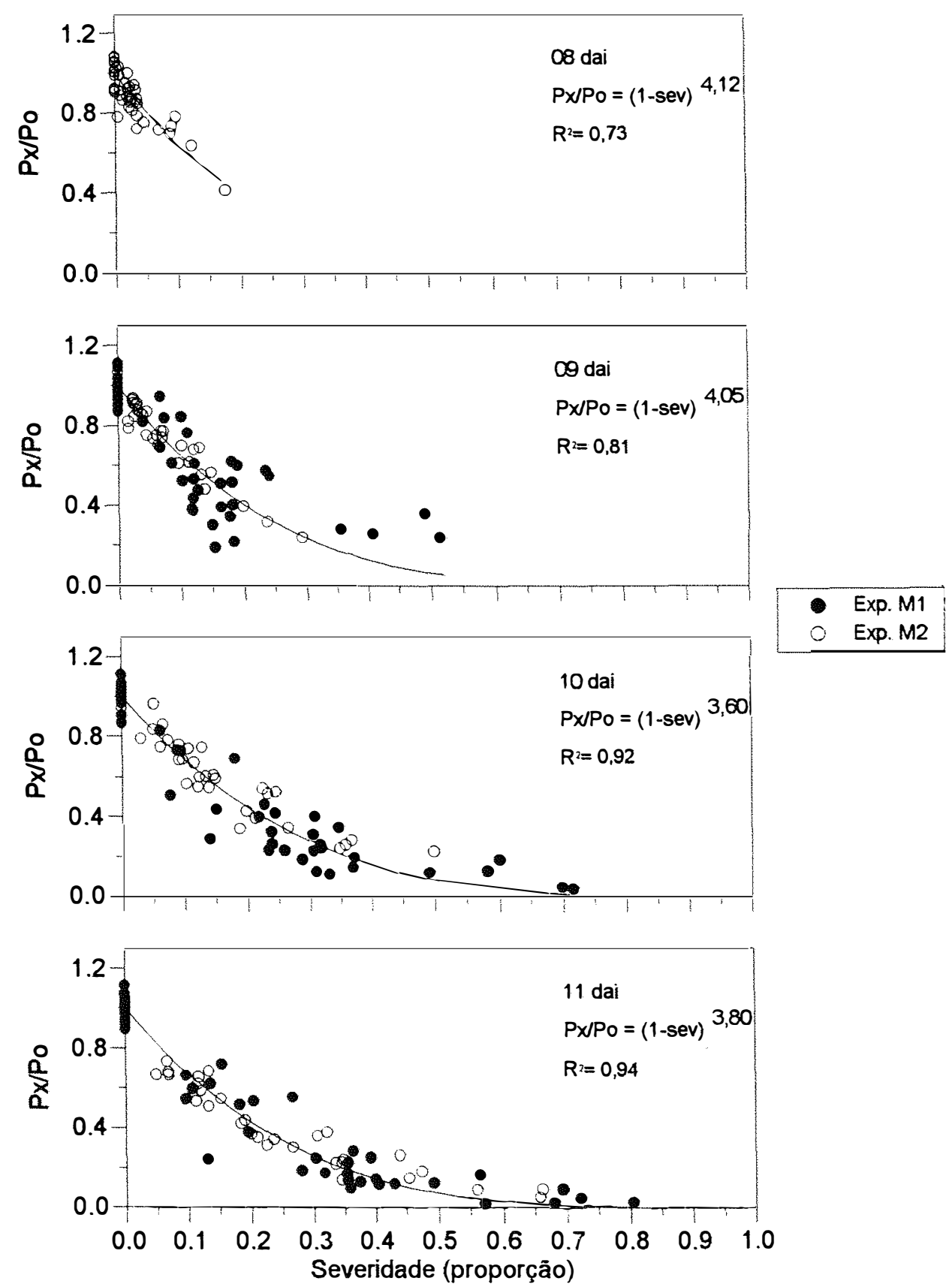

Figura 08. Relação entre a taxa fotossintética líquida relativa e a severidade de mancha angular em folíolos de feijoeiro cv. Rosinha G-2 crescidos a $22{ }^{\circ} \mathrm{C}$ aos $8,9,10$ e 11 dias após a inoculação. 

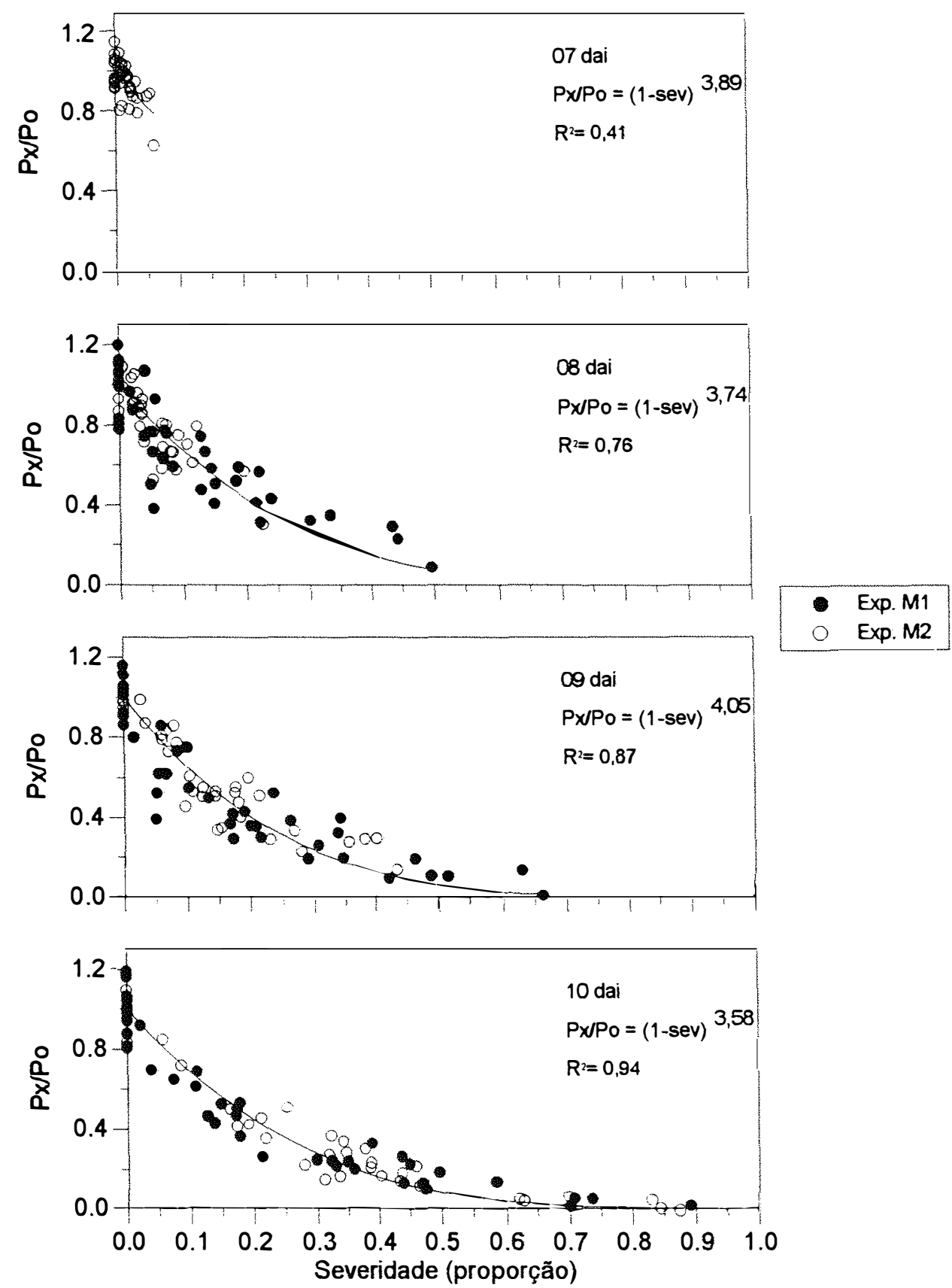

Figura 09. Relação entre a taxa fotossintética líquida relativa e a severidade de mancha angular em folíolos de feijoeiro cv. Rosinha G-2 crescidos a $25^{\circ} \mathrm{C}$ aos 7, 8, 9 e 10 dias após a inoculação. 

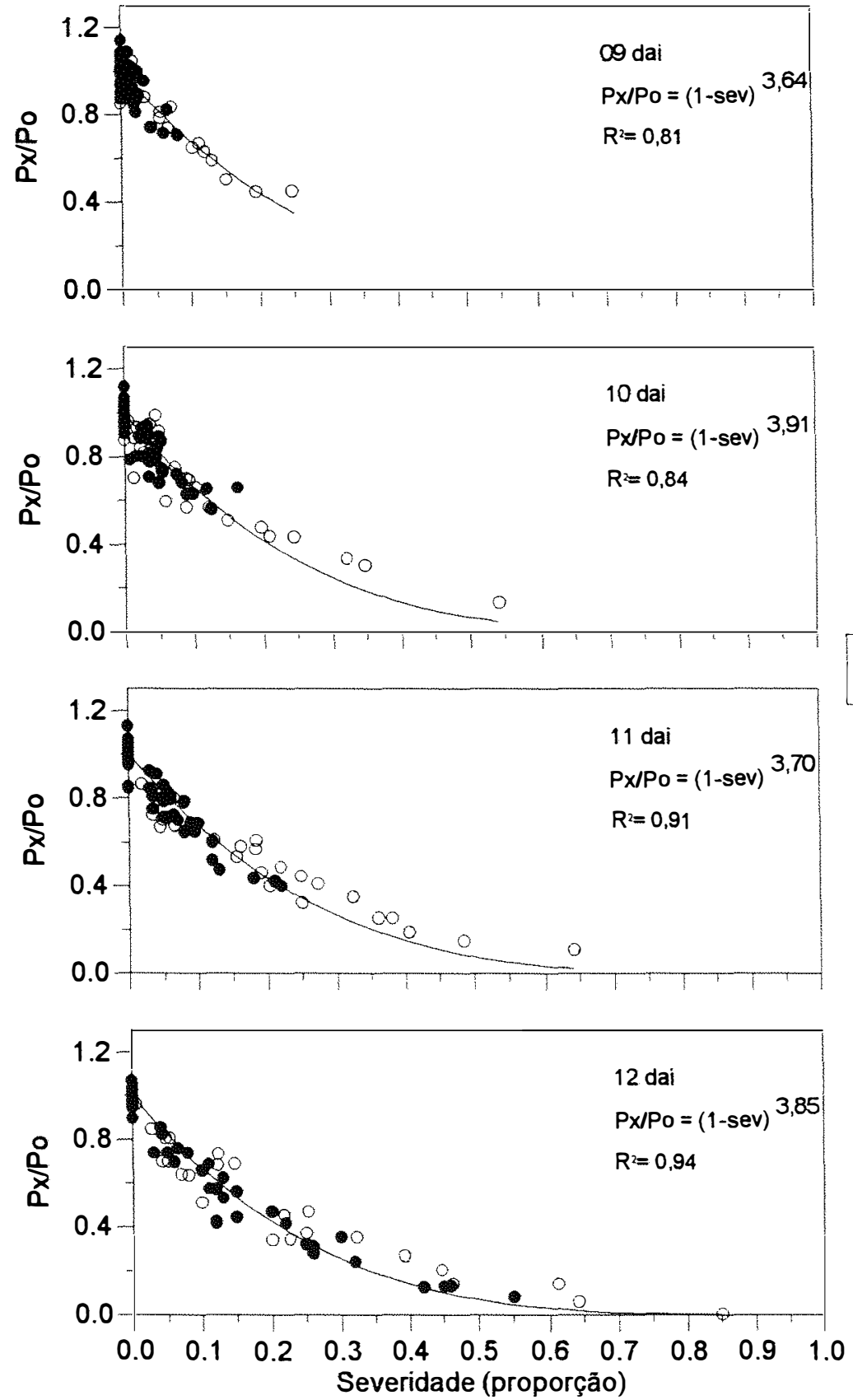

Figura 10. Relação entre a taxa fotossintética líquida relativa e a severidade de mancha angular em folíolos de feijoeiro cv. Carioca Comum crescidos a $19{ }^{\circ} \mathrm{C}$ aos 9 , 10,11 e 12 dias após a inoculação. 

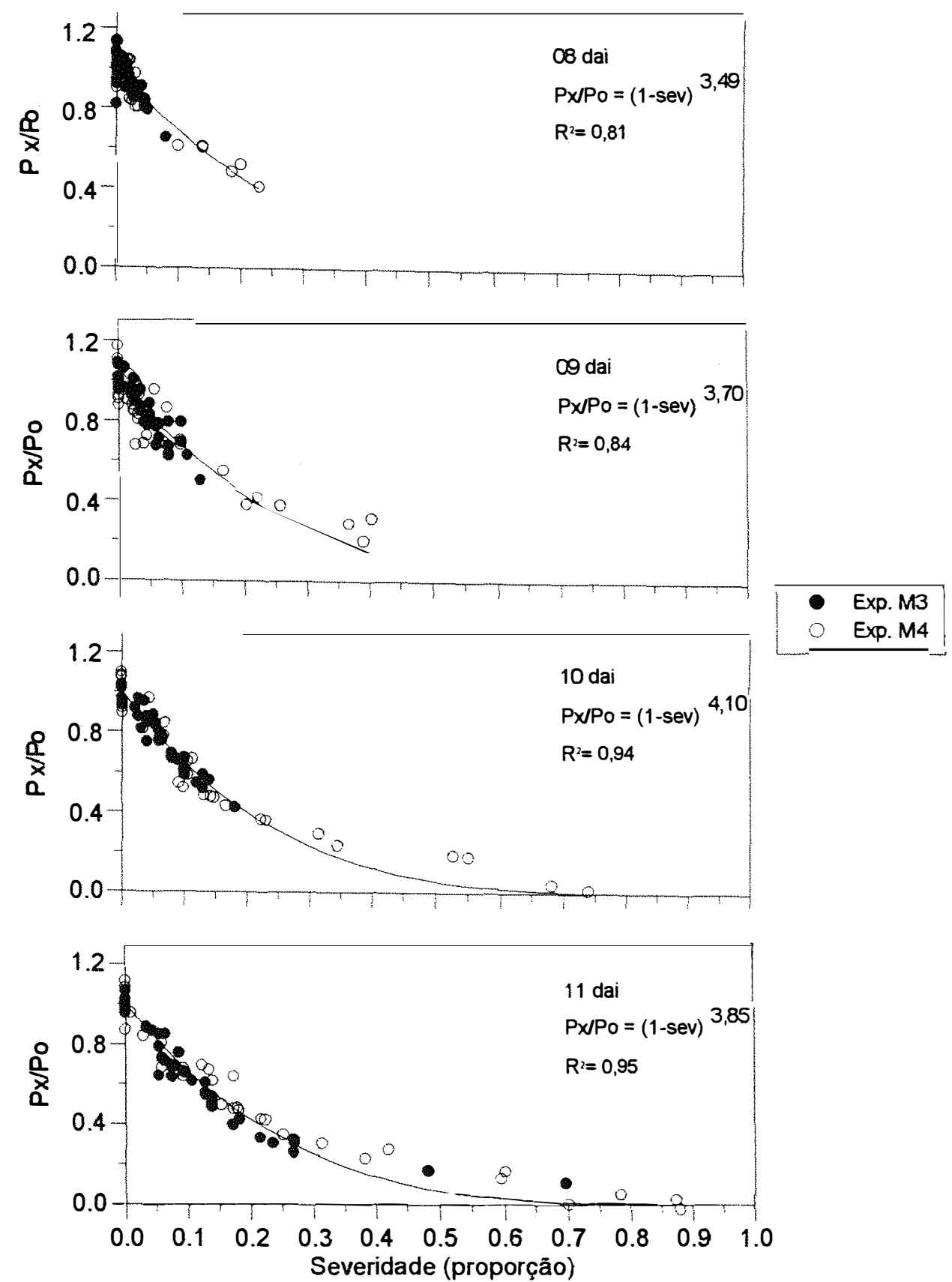

Figura 11. Relação entre a taxa fotossintética líquida relativa e a severidade de mancha angular em folíolos de feijoeiro cv. Carioca Comum crescidos a $22^{\circ} \mathrm{C}$ aos 8,9 , 10 e 11 dias após a inoculação. 

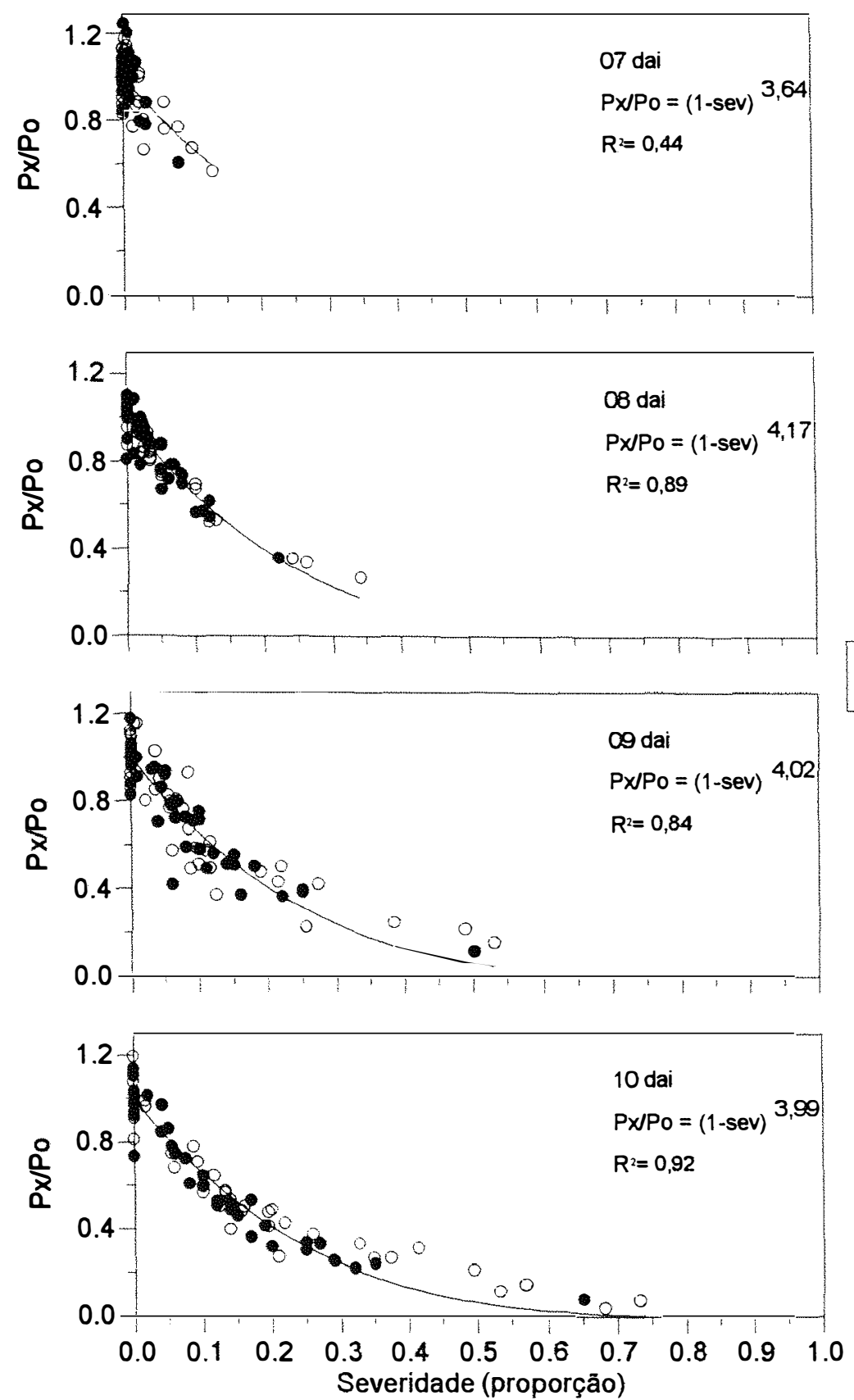

Figura 12. Relação entre a taxa fotossintética líquida relativa e a severidade de mancha angular em folíolos de feijoeiro cv. Carioca Comum crescidos a $25^{\circ} \mathrm{C}$ aos 7,8 , 9 e 10 dias após a inoculação. 

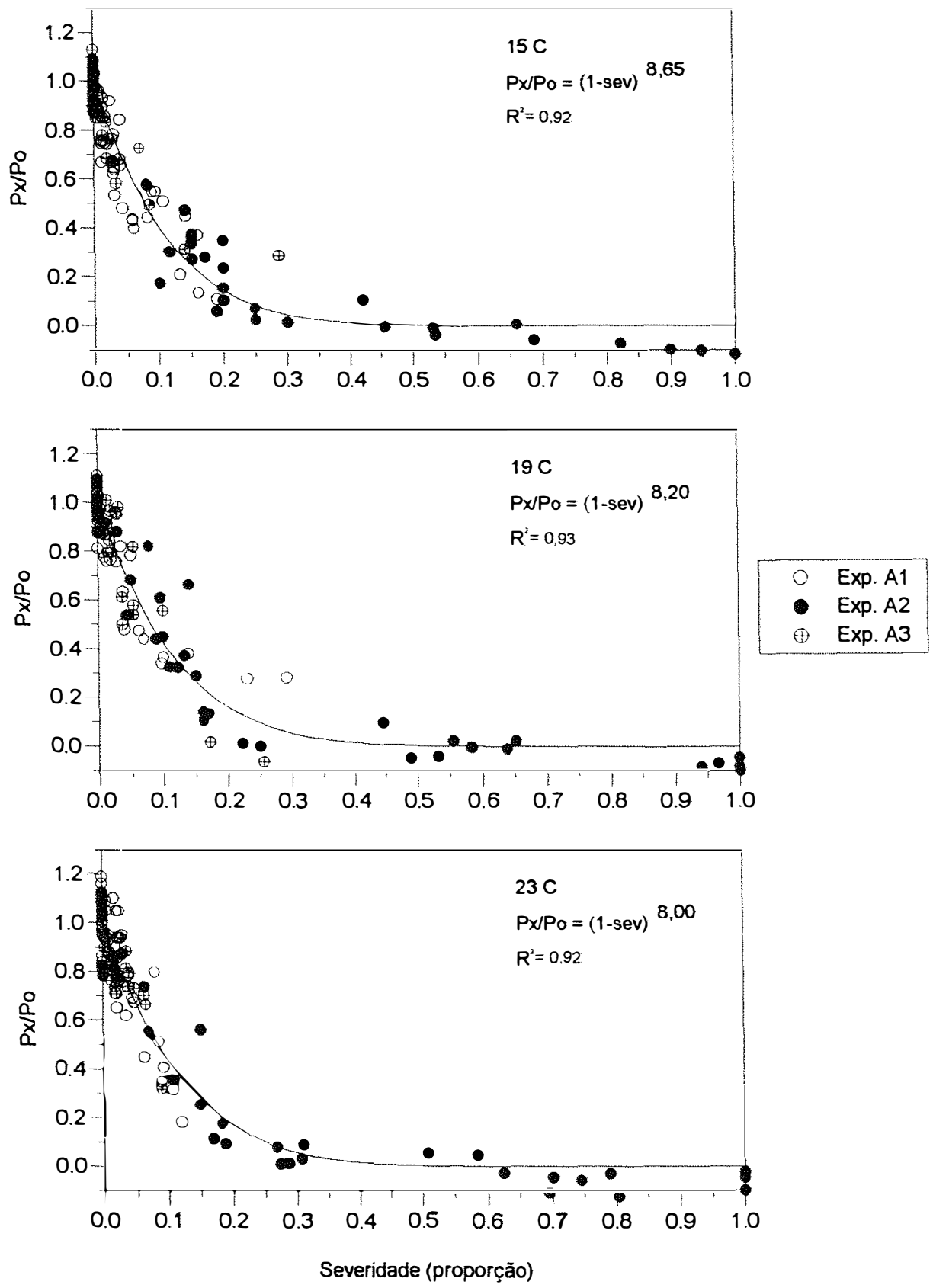

Figura 13. Relação entre a taxa fotossintética líquida relativa e a severidade de antracnose em folíolos de feijoeiro cv. Rosinha G-2 crescidos a 15,19 e $23^{\circ} \mathrm{C}$. 

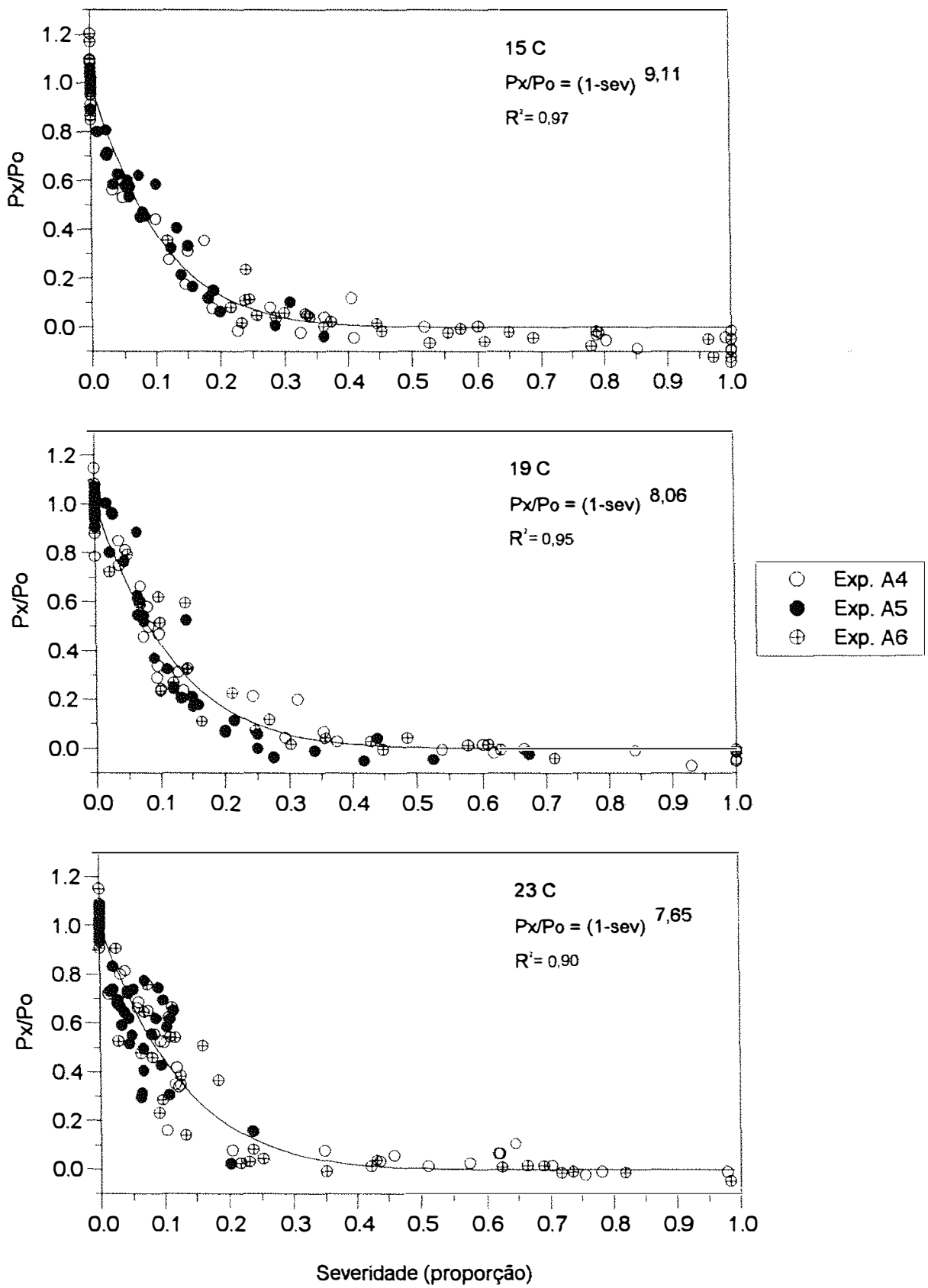

Figura 14. Relação entre a taxa fotossintética líquida relativa e a severidade de antracnose em folíolos de feijoeiro cv. Carioca Comum crescidos a 15,19 e $23^{\circ} \mathrm{C}$. 
Carioca
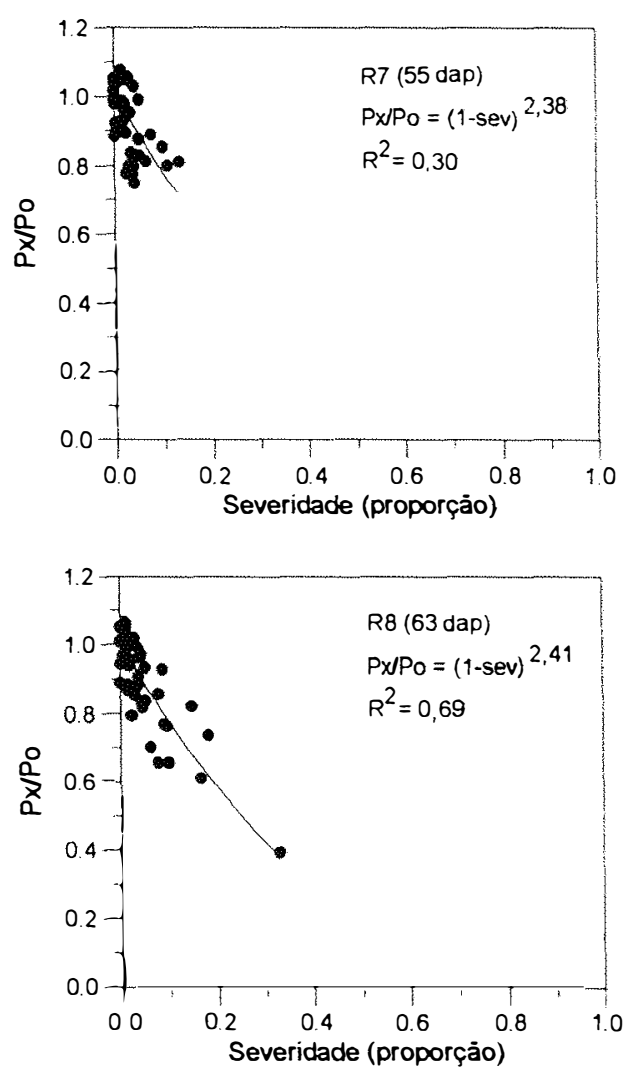

Rosinha
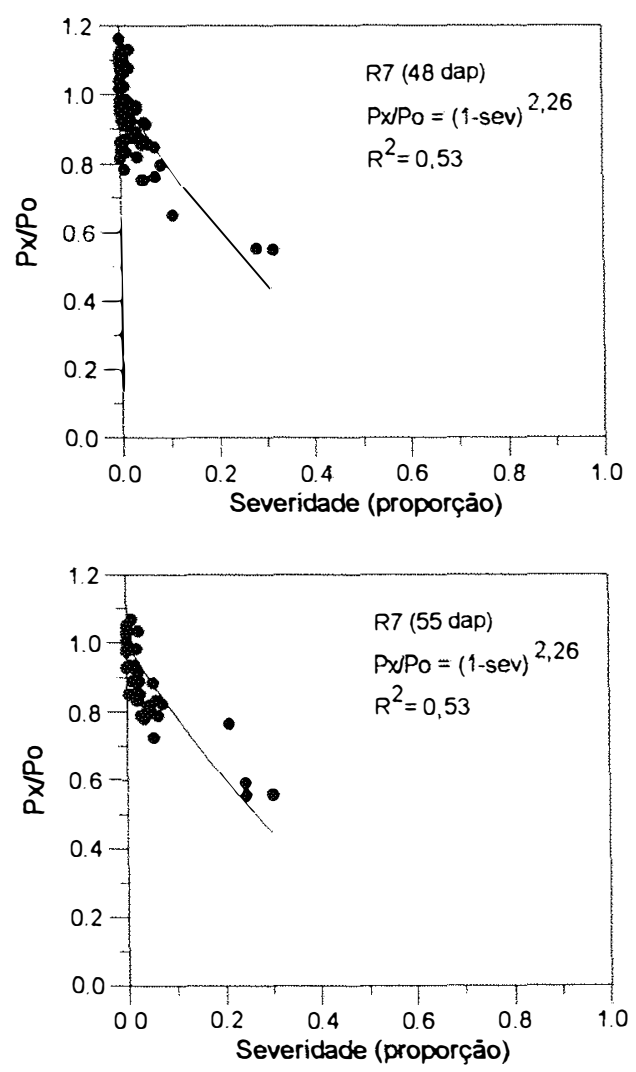

Figura 15. Relação entre a taxa fotossintética líquida relativa e a severidade de ferrugem em folíolos de duas cultivares de feijoeiro em diferentes estádios fenológicos no experimento de campo 1 . 
Carioca
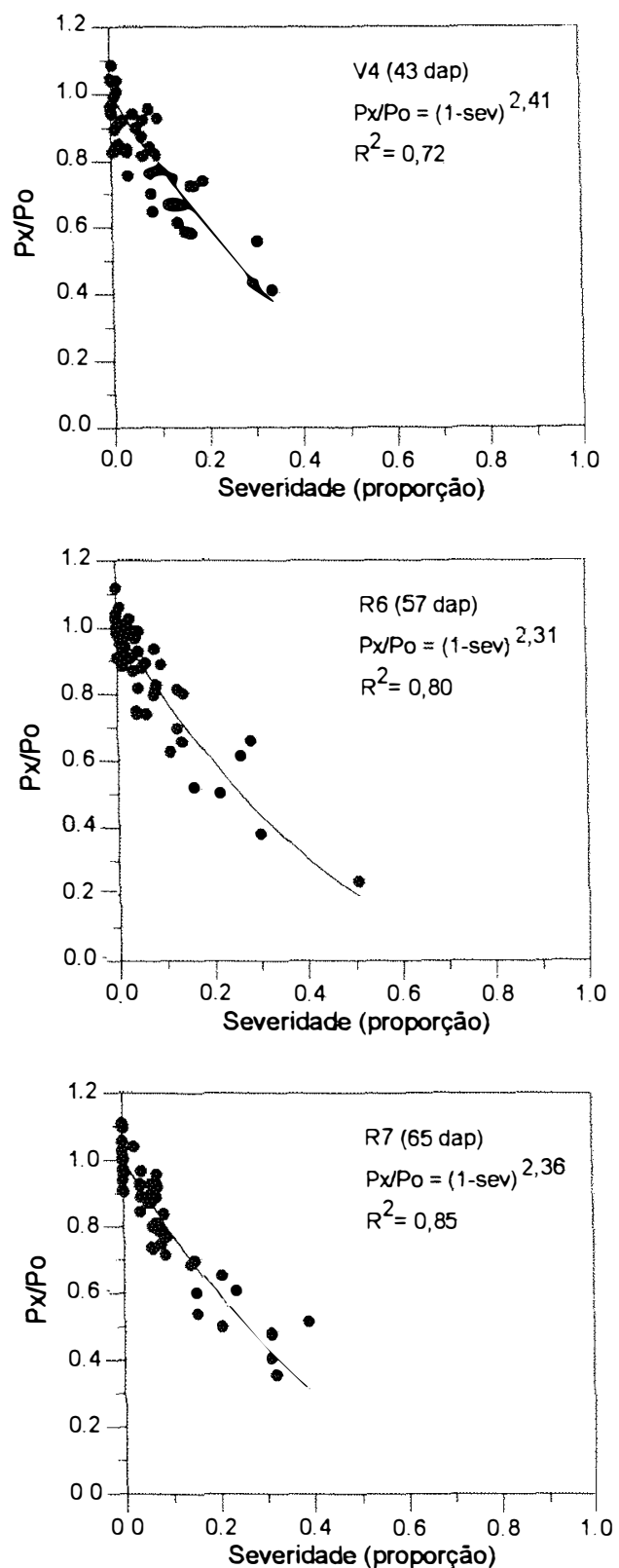
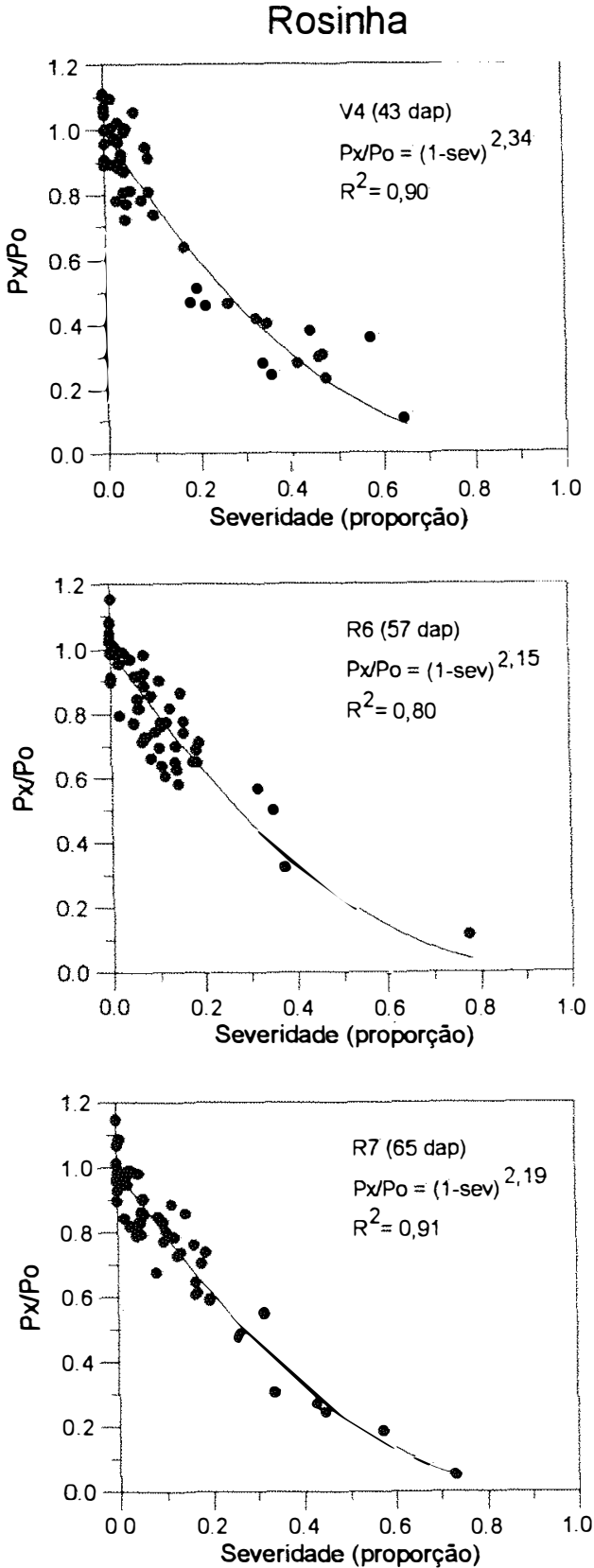

Figura 16. Relação entre a taxa fotossintética líquida relativa e a severidade de ferrugem em folíolos de duas cultivares de feijoeiro em diferentes estádios fenológicos no experimento de campo 2 . 


\section{Carioca}
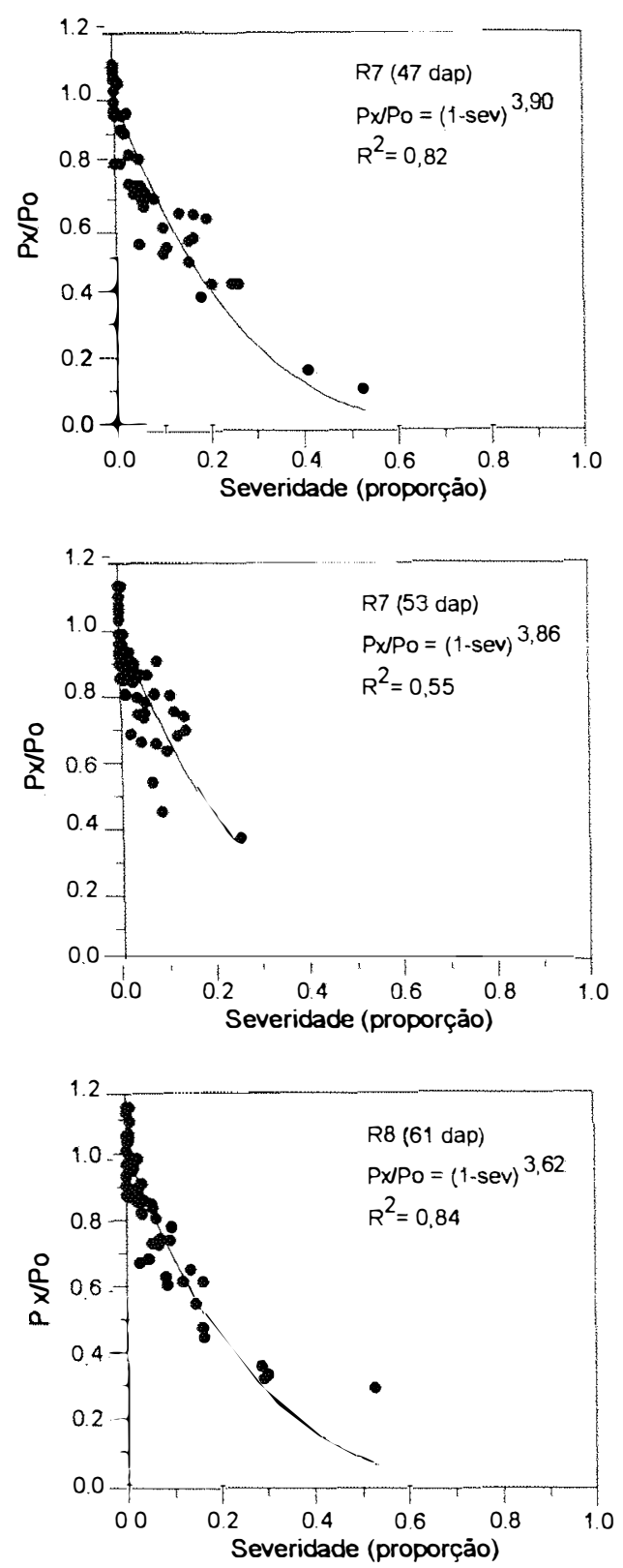

Rosinha
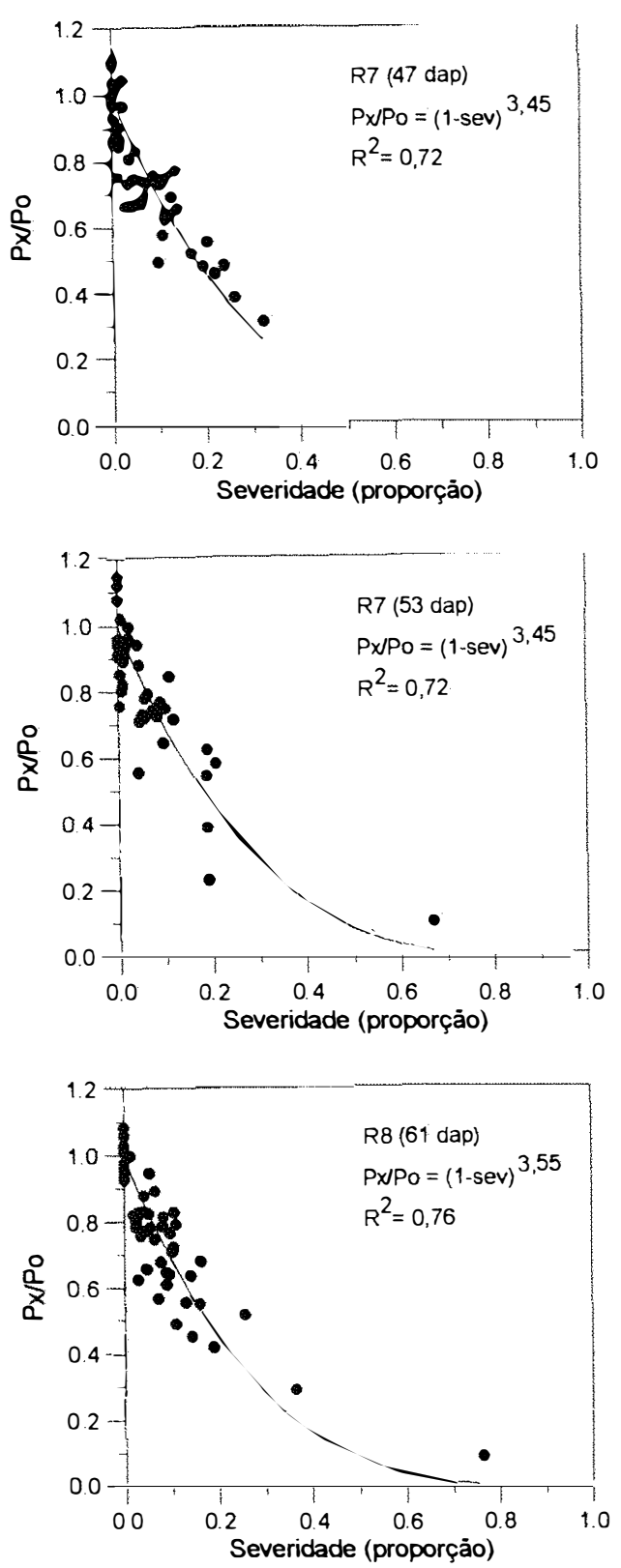

Figura 17. Relação entre a taxa fotossintética líquida relativa e a severidade de mancha angular em folíolos de duas cultivares de feijoeiro em diferentes estádios fenológicos no experimento de campo 1. 
Carioca
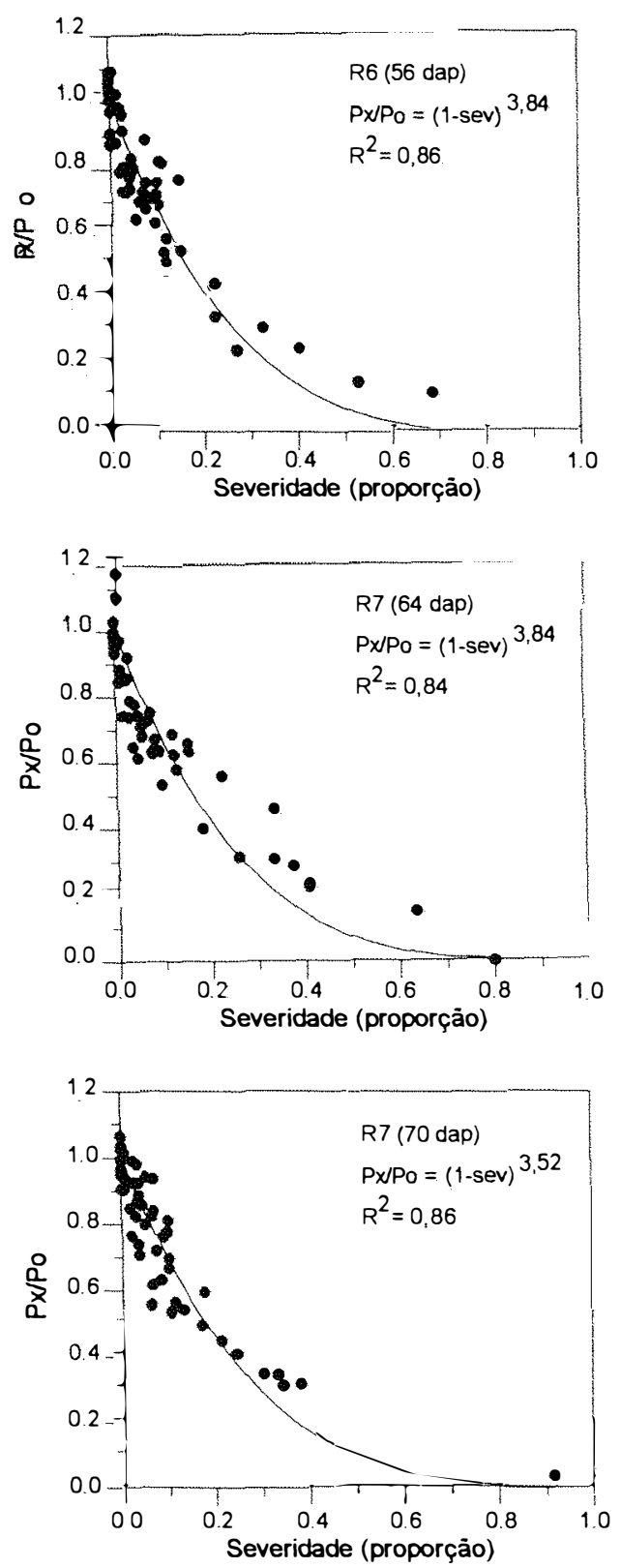

Rosinha
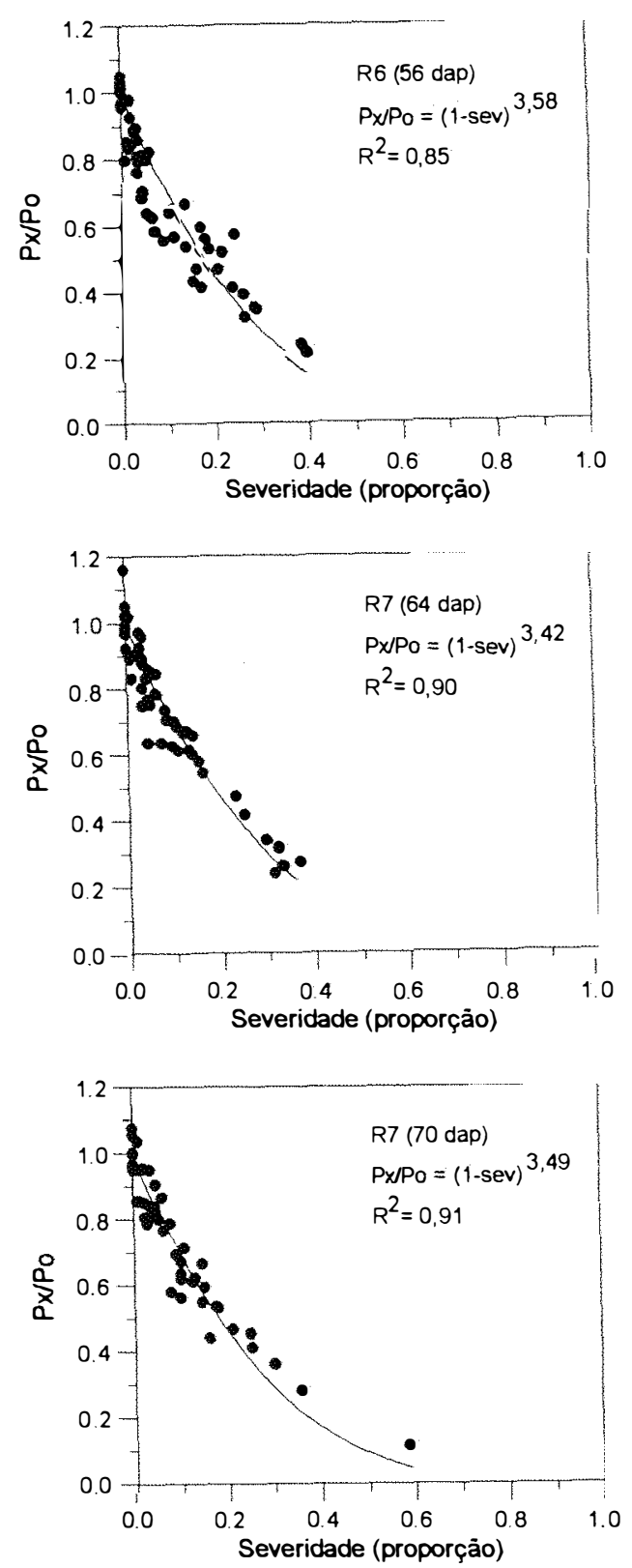

Figura 18. Relação entre a taxa fotossintética líquida relativa e a severidade de mancha angular em folíolos de duas cultivares de feijoeiro em diferentes estádios fenológicos no experimento de campo 2. 

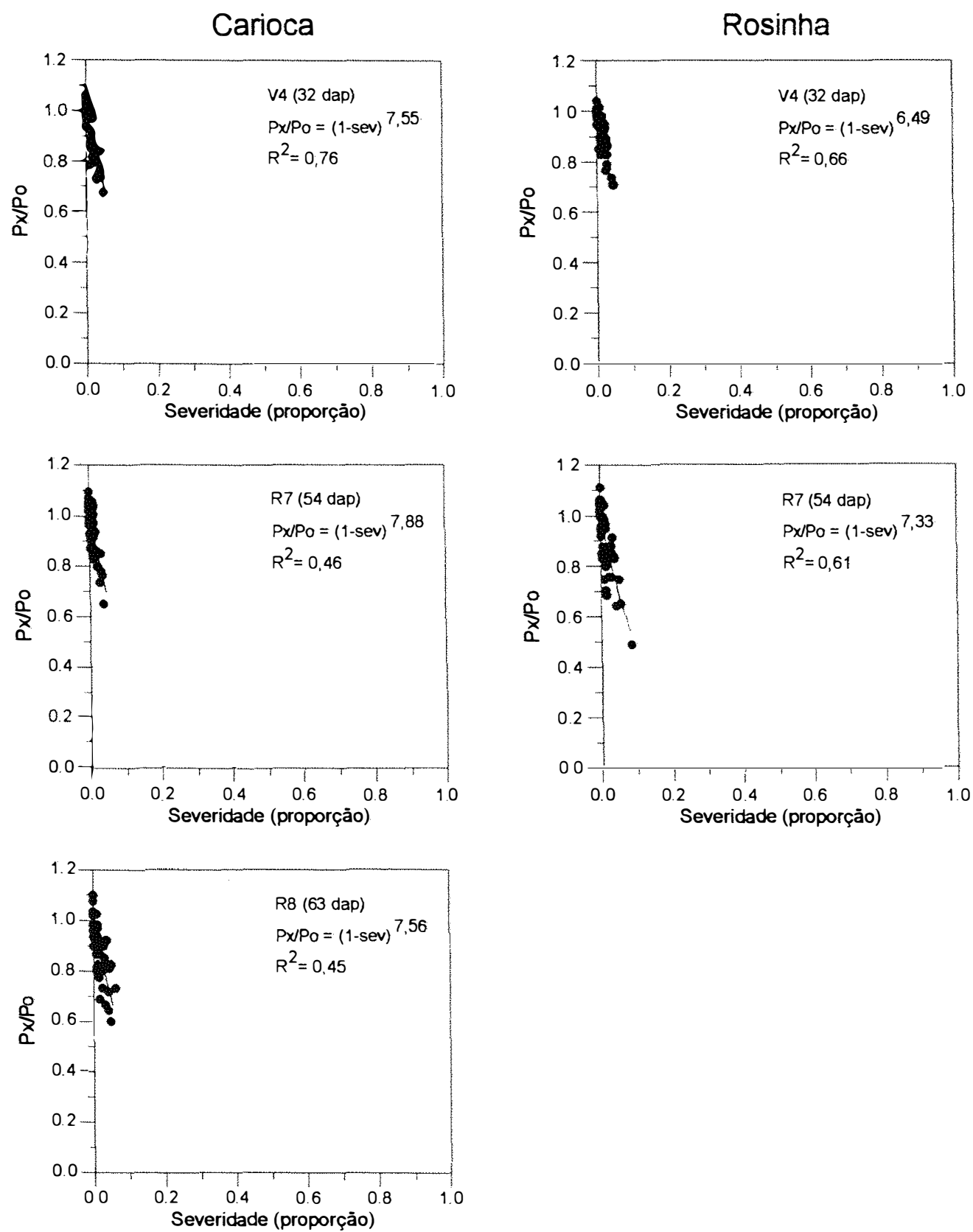

Figura 19. Relação entre a taxa fotossintética líquida relativa e a severidade de antracnose em folíolos de duas cultivares de feijoeiro em diferentes estádios fenológicos no experimento de campo 1 . 

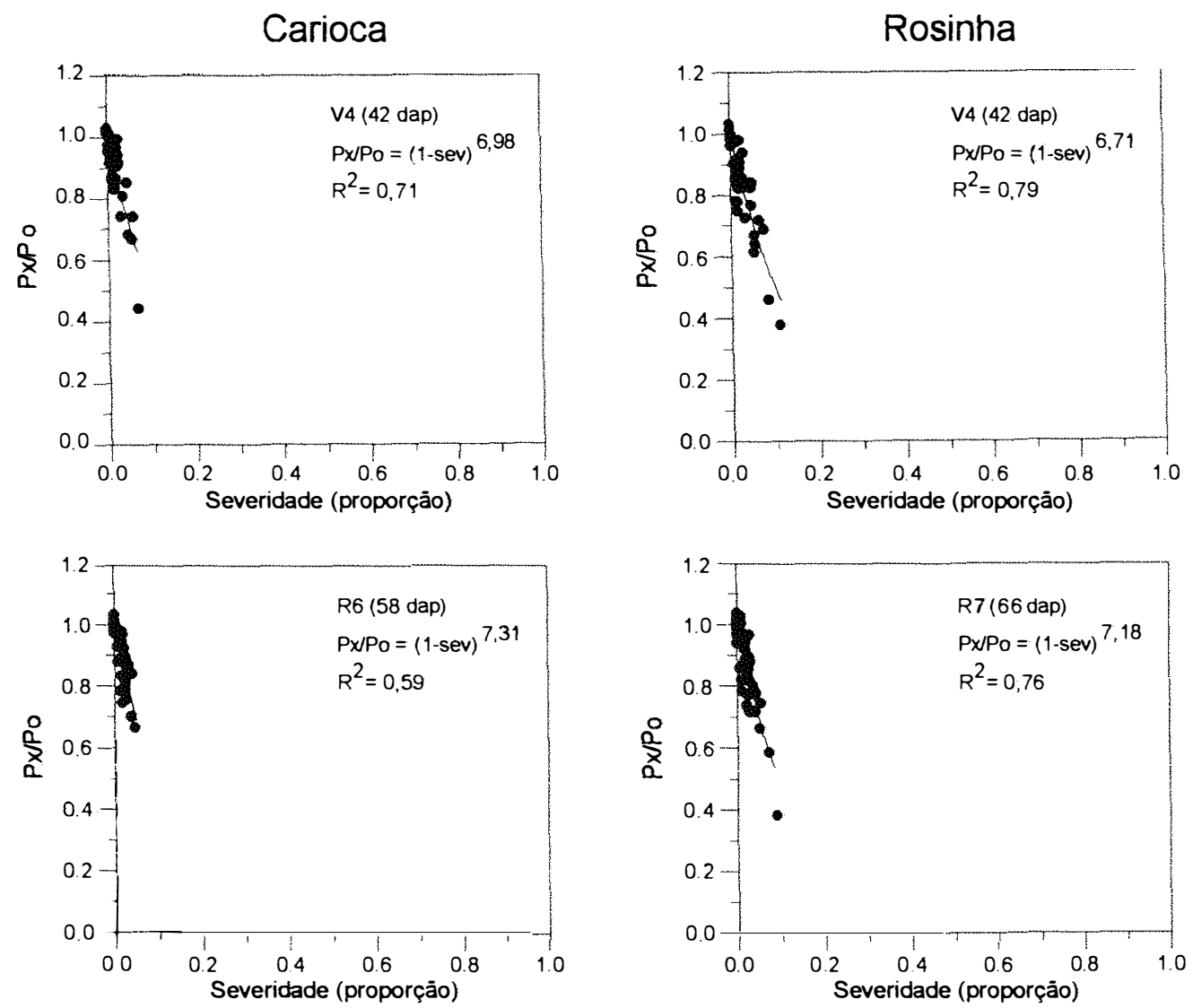

Figura 20. Relação entre a taxa fotossintética líquida relativa e a severidade de antracnose em folíolos de duas cultivares de feijoeiro em diferentes estádios fenológicos no experimento de campo 2 . 


\section{APÊNDICE 4}

FIGURAS DAS RELAÇÕES ENTRE A PRODUÇÃO POR PLANTA DE FEIJOEIRO E AS VARIÁVEIS $A U D P C, A U V D P C, H A D, P A D, H A A$ E PAA E DA DISTRIBUIÇÃO DOS RESÍDUOS. 

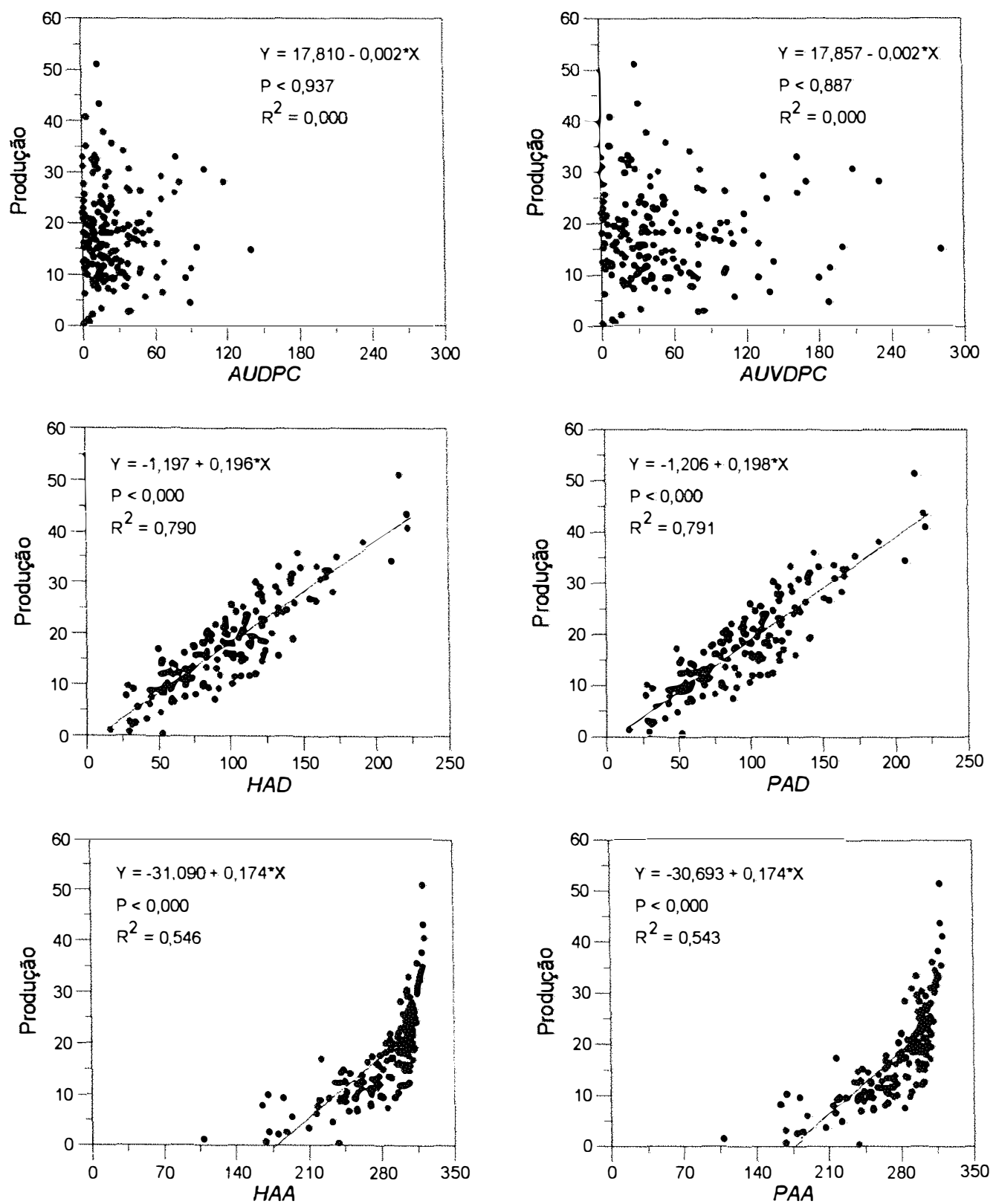

Figura 01. Produção por planta (g) em função da $A U D P C, A U V D P C, H A D$ (dias), $P A D$ (dias), $H A A\left(\mathrm{MJ} \mathrm{m}^{-2}\right)$ e $P A A\left(\mathrm{MJ} \mathrm{m}^{-2}\right)$ de plantas de feijoeiro com ferrugem no experimento F-I (Iamauti, 1995). 

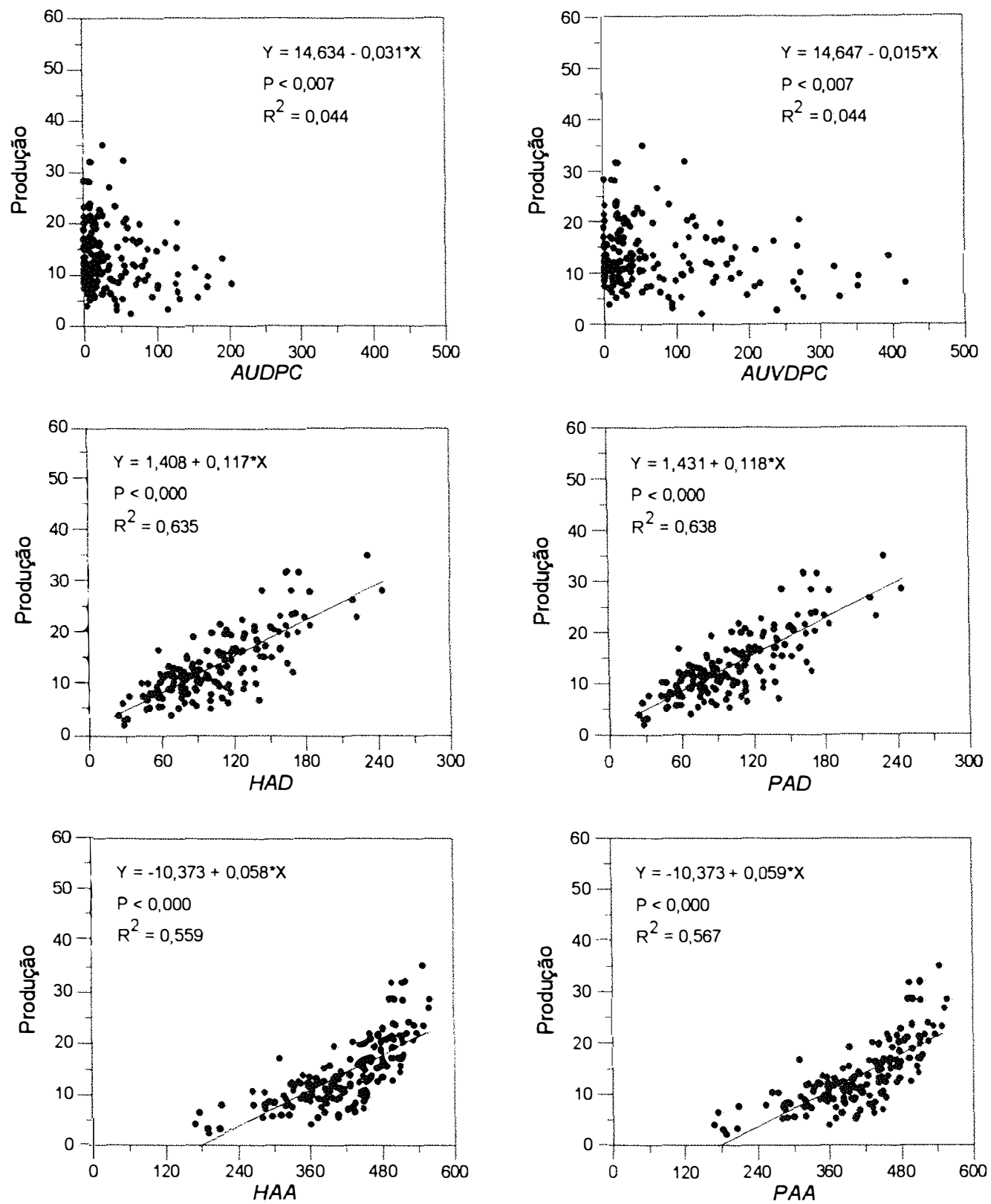

Figura 02. Produção por planta (g) em função da $A U D P C, A U V D P C, H A D$ (dias), $P A D$ (dias), $H A A\left(\mathrm{MJ} \mathrm{m}^{-2}\right)$ e $P A A\left(\mathrm{MJ} \mathrm{m}^{-2}\right)$ de plantas de feijoeiro com ferrugem no experimento F-II (Iamauti, 1995) 

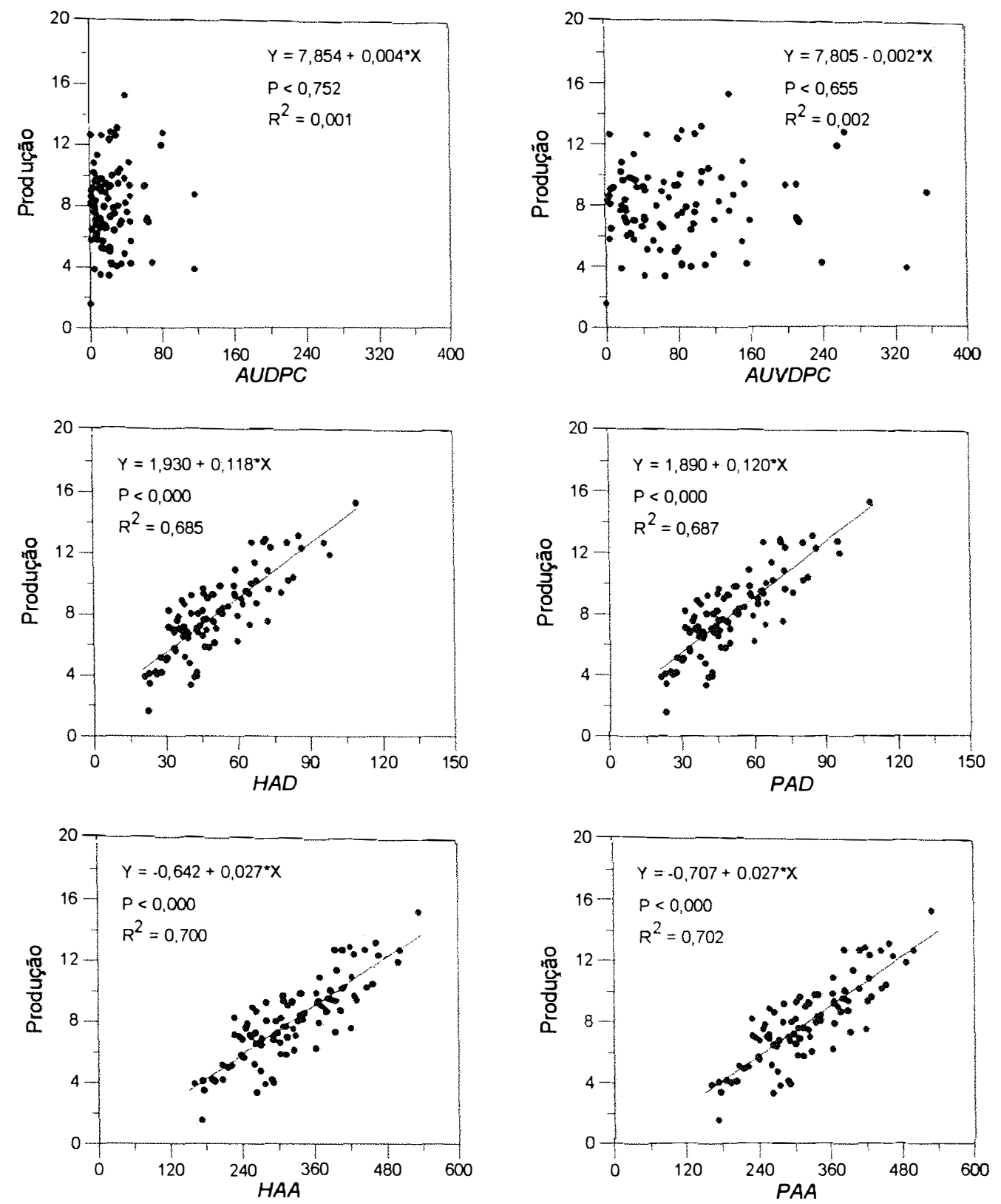

Figura 03. Produção por planta (g) em função da $A U D P C, A U V D P C, H A D$ (dias), $P A D$ (dias), $H A A\left(\mathrm{MJ} \mathrm{m}^{-2}\right)$ e $P A A\left(\mathrm{MJ} \mathrm{m}^{-2}\right)$ de plantas de feijoeiro com mancha angular no experimento M-I (Carneiro, 1995). 

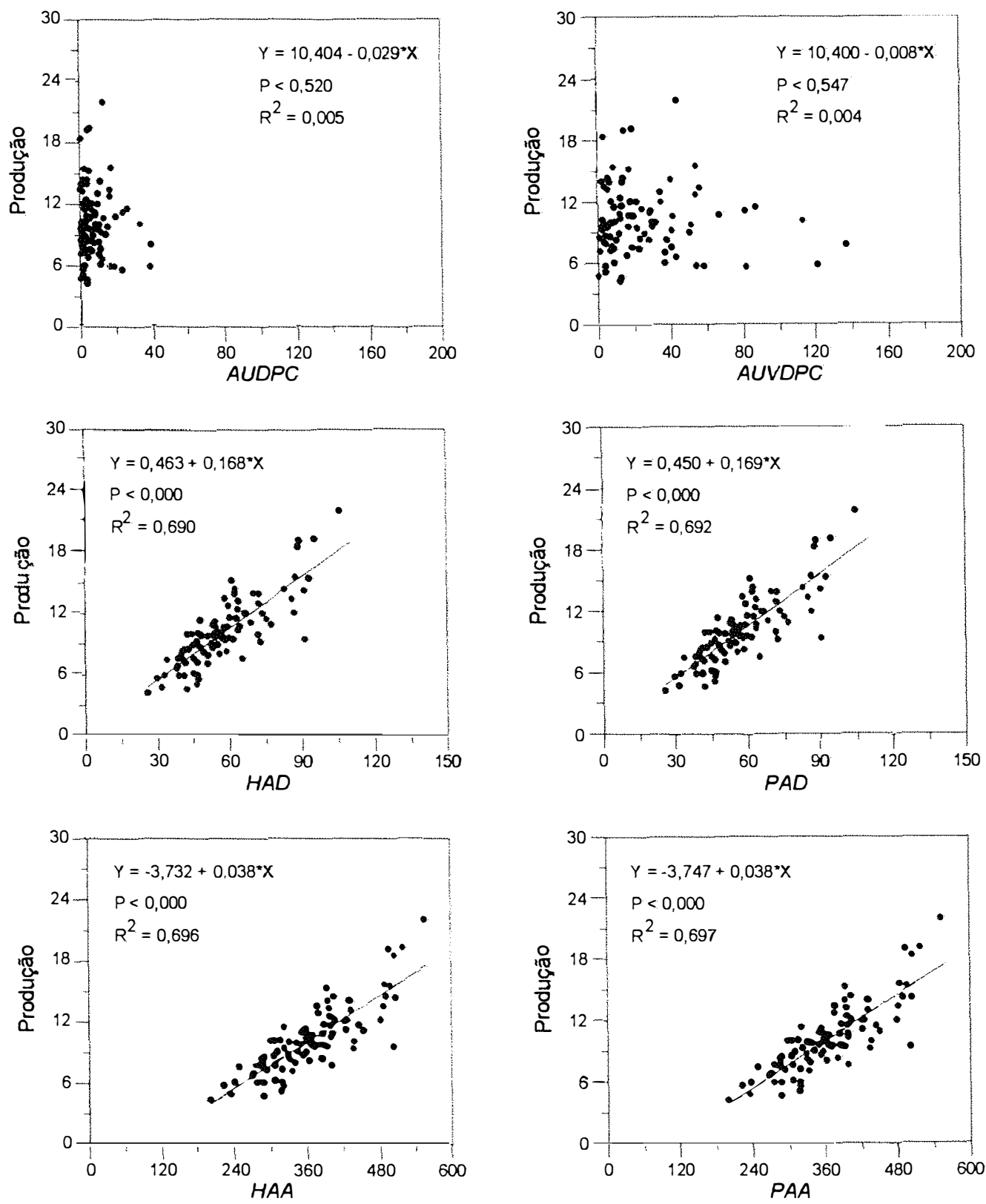

Figura 04. Produção por planta (g) em função da $A U D P C, A U V D P C, H A D$ (dias), $P A D$ (dias), $H A A\left(\mathrm{MJ} \mathrm{m}^{-2}\right)$ e $P A A\left(\mathrm{MJ} \mathrm{m}^{-2}\right)$ de plantas de feijoeiro com mancha angular no experimento M-II (Carneiro, 1995). 

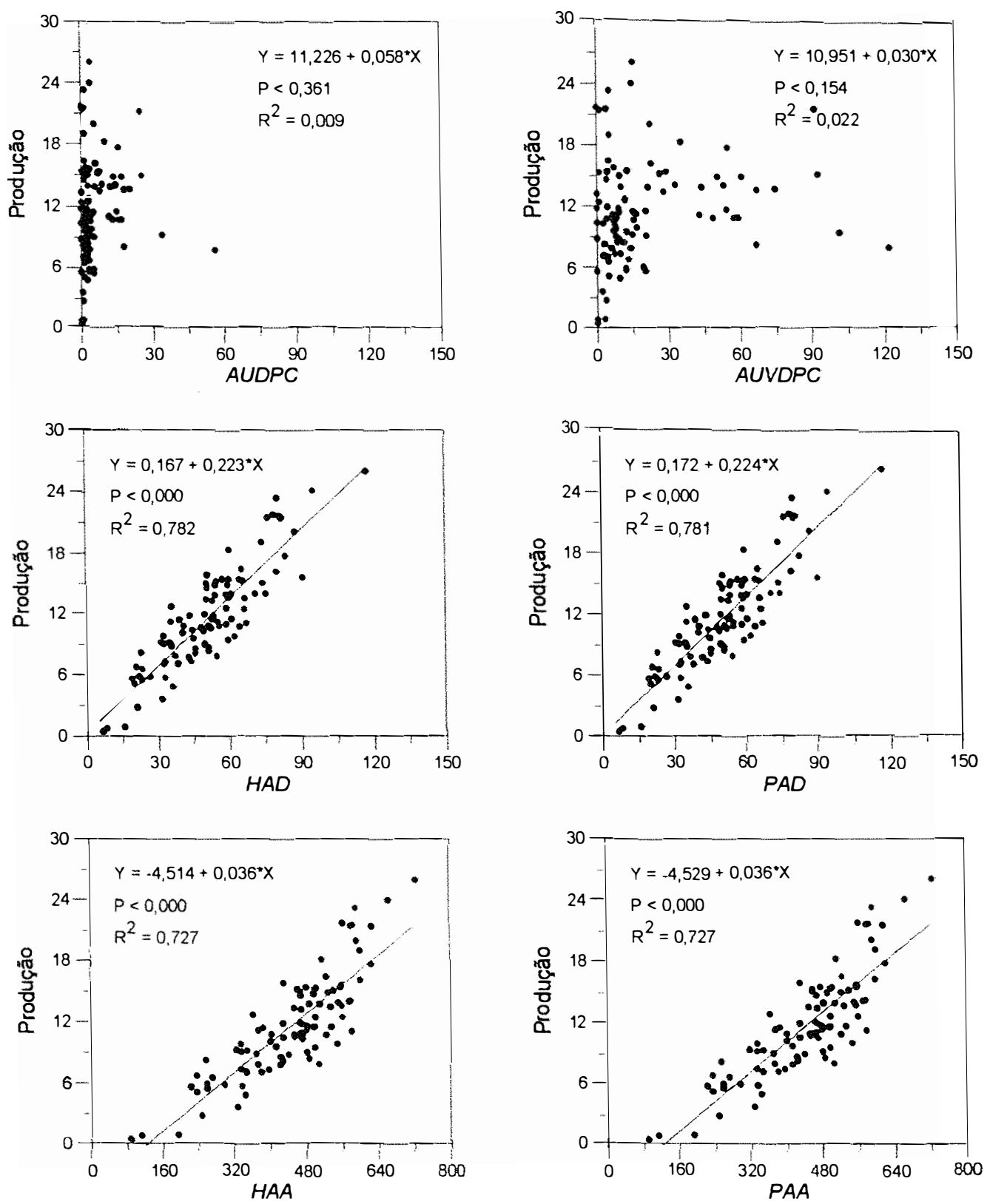

Figura 05. Produção por planta (g) em função da $A U D P C, A U V D P C, H A D$ (dias), PAD (dias), $H A A\left(\mathrm{MJ} \mathrm{m}^{-2}\right)$ e $P A A\left(\mathrm{MJ} \mathrm{m}^{-2}\right)$ de plantas de feijoeiro com mancha angular no experimento M-III (Carneiro, 1995). 

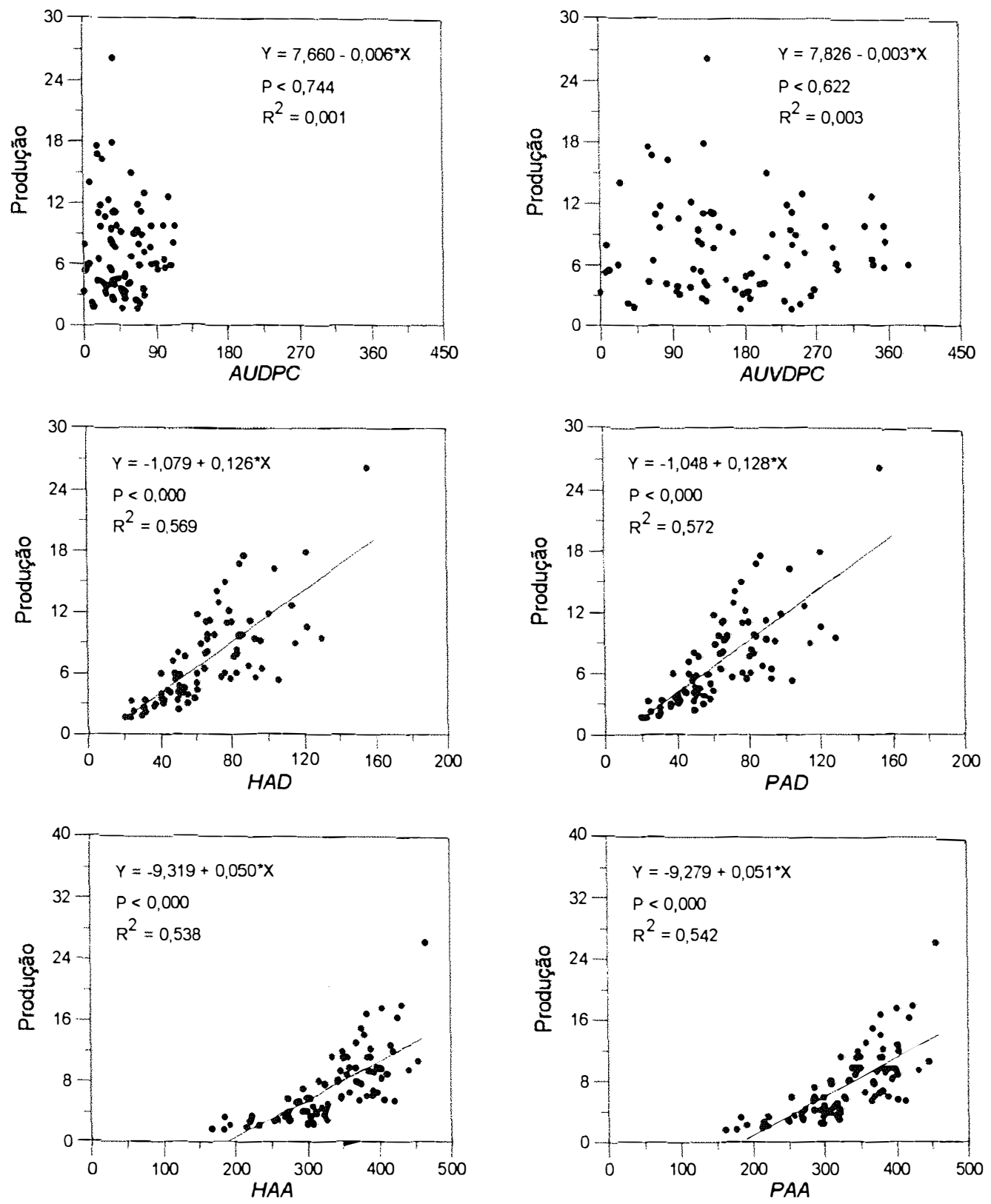

Figura 06. Produção por planta (g) em função da $A U D P C, A U V D P C, H A D$ (dias), $P A D$ (dias), $H A A\left(\mathrm{MJ} \mathrm{m}^{-2}\right)$ e $P A A\left(\mathrm{MJ} \mathrm{m}^{-2}\right)$ de plantas de feijoeiro com mancha angular no experimento M-IV (Godoy, 1995). 

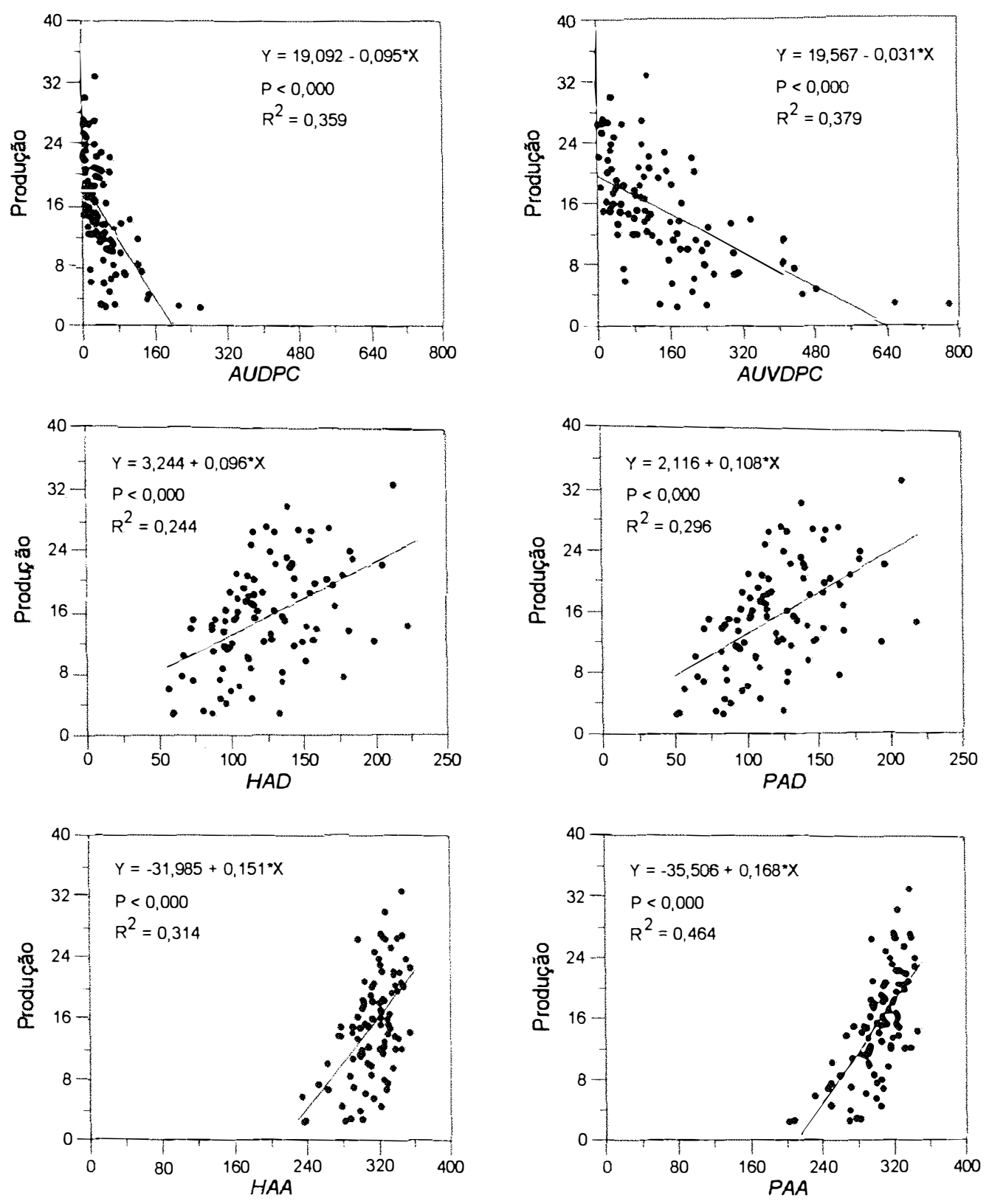

Figura 07. Produção por planta (g) em função da $A U D P C, A U V D P C, H A D$ (dias), $P A D$ (dias), HAA ( $\left.\mathrm{MJ} \mathrm{m}^{-2}\right)$ e $P A A\left(\mathrm{MJ} \mathrm{m}^{-2}\right)$ de plantas de feijoeiro com mancha angular no experimento M-V (Godoy, 1995). 

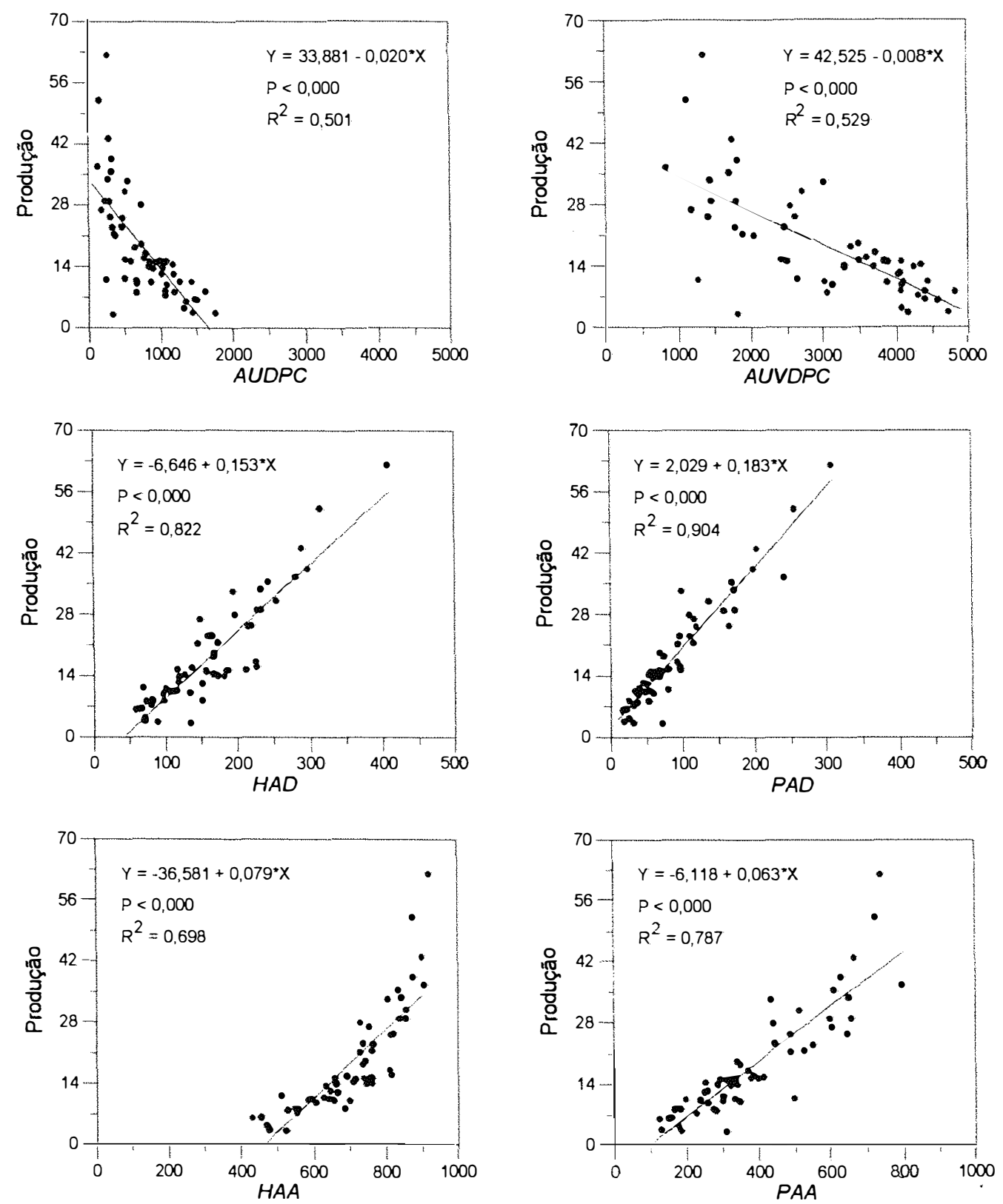

Figura 08. Produção por planta (g) em função da $A U D P C, A U V D P C, H A D$ (dias), $P A D$ (dias), $H A A\left(\mathrm{MJ} \mathrm{m}^{-2}\right)$ e $P A A\left(\mathrm{MJ} \mathrm{m}^{-2}\right)$ de plantas de feijoeiro com antracnose no experimento A-I (Gianasi, 1999). 

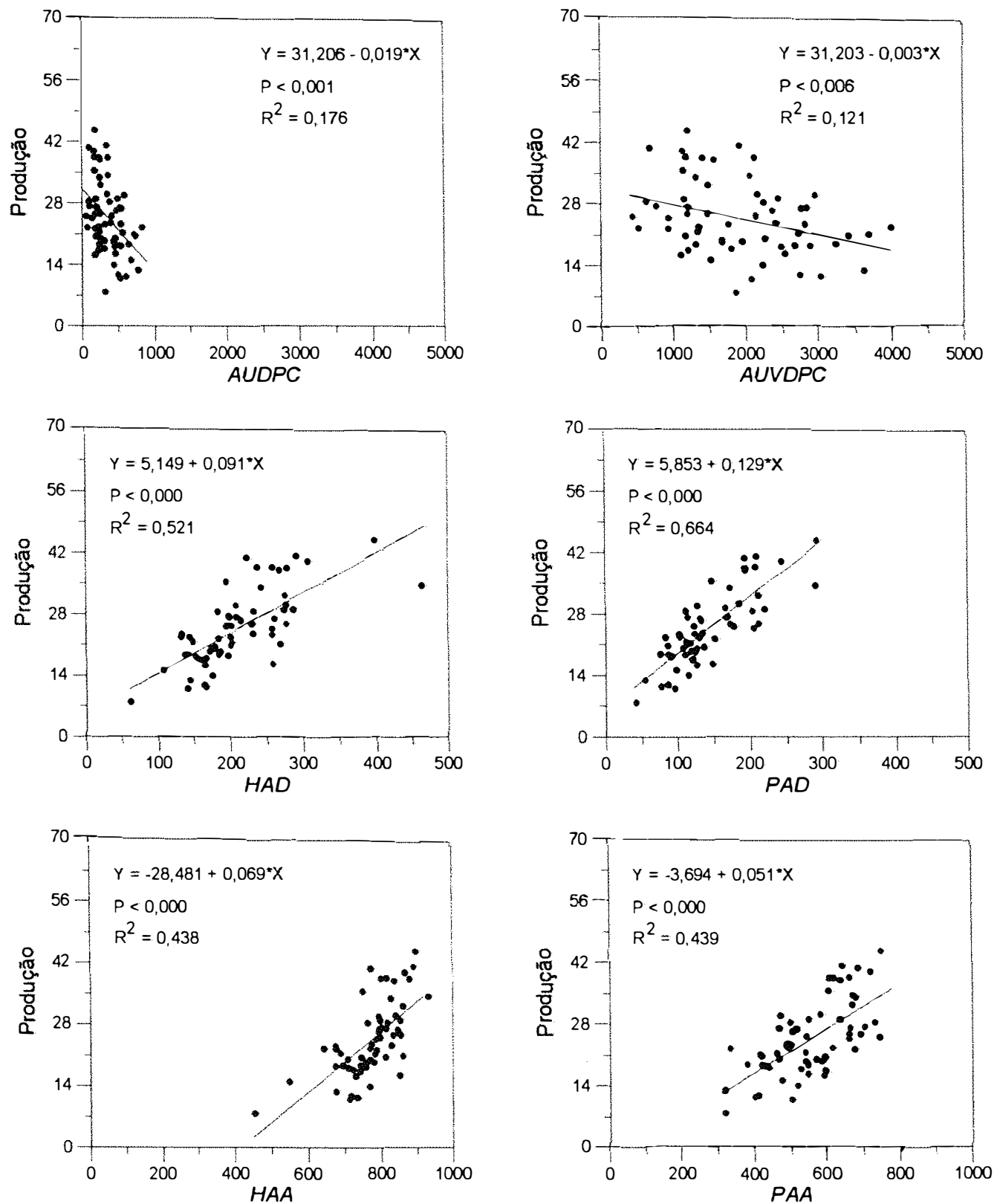

Figura 09. Produção por planta (g) em função da $A U D P C, A U V D P C, H A D$ (dias), $P A D$ (dias), $H A A\left(\mathrm{MJ} \mathrm{m}^{-2}\right)$ e $P A A\left(\mathrm{MJ} \mathrm{m}^{-2}\right)$ de plantas de feijoeiro com antracnose no experimento A-II (Gianasi, 1999). 

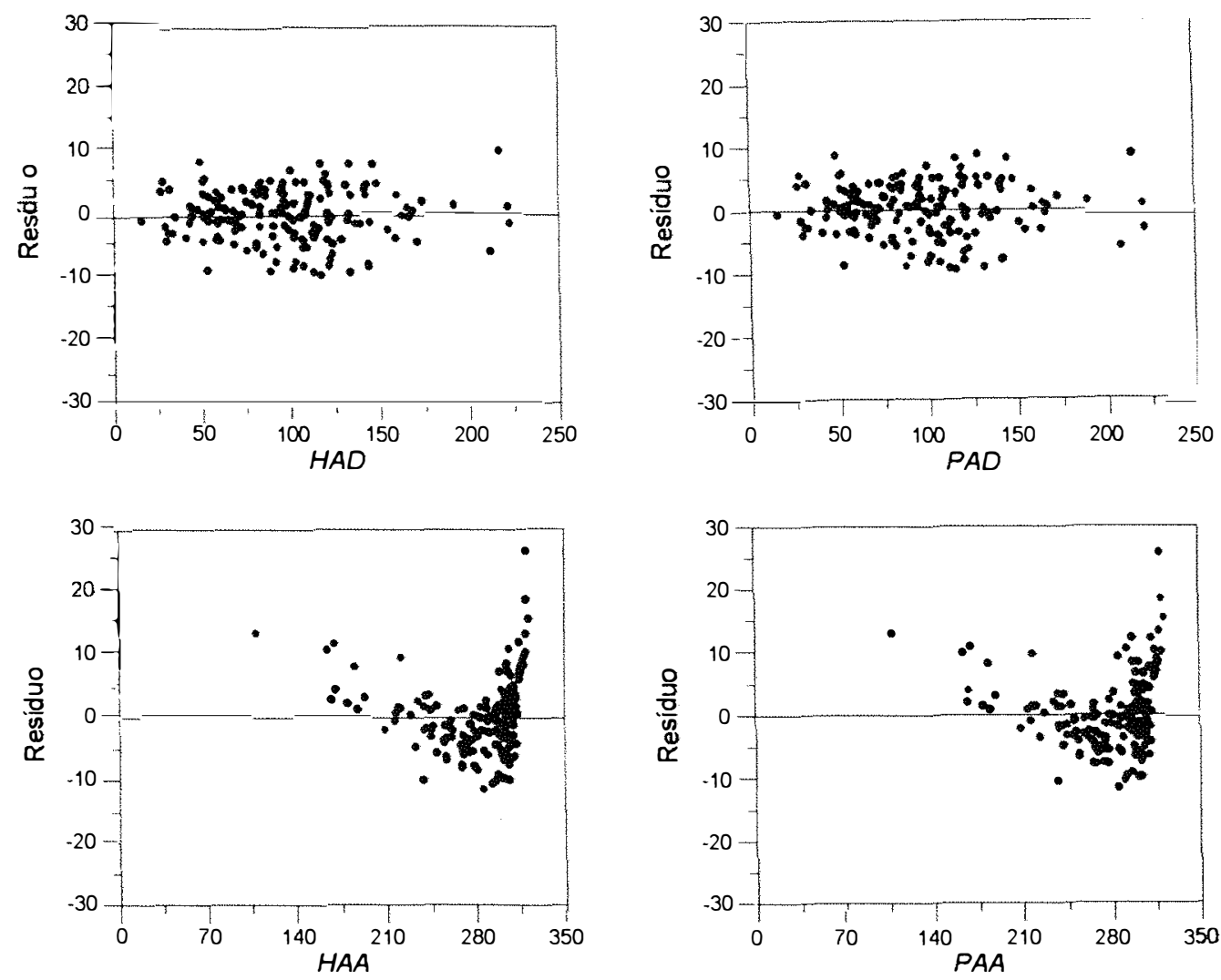

Figura 10. Distribuição dos resíduos (valor observado - valor previsto da produção pela regressão linear) em função das variáveis independentes $H A D$ (dias), $P A D$ (dias), $H A A\left(\mathrm{MJ} \mathrm{m}^{-2}\right)$ e $P A A\left(\mathrm{MJ} \mathrm{m}^{-2}\right)$ no experimento $\mathrm{F}-\mathrm{I}$ com ferrugem (Iamauti, 1995). 

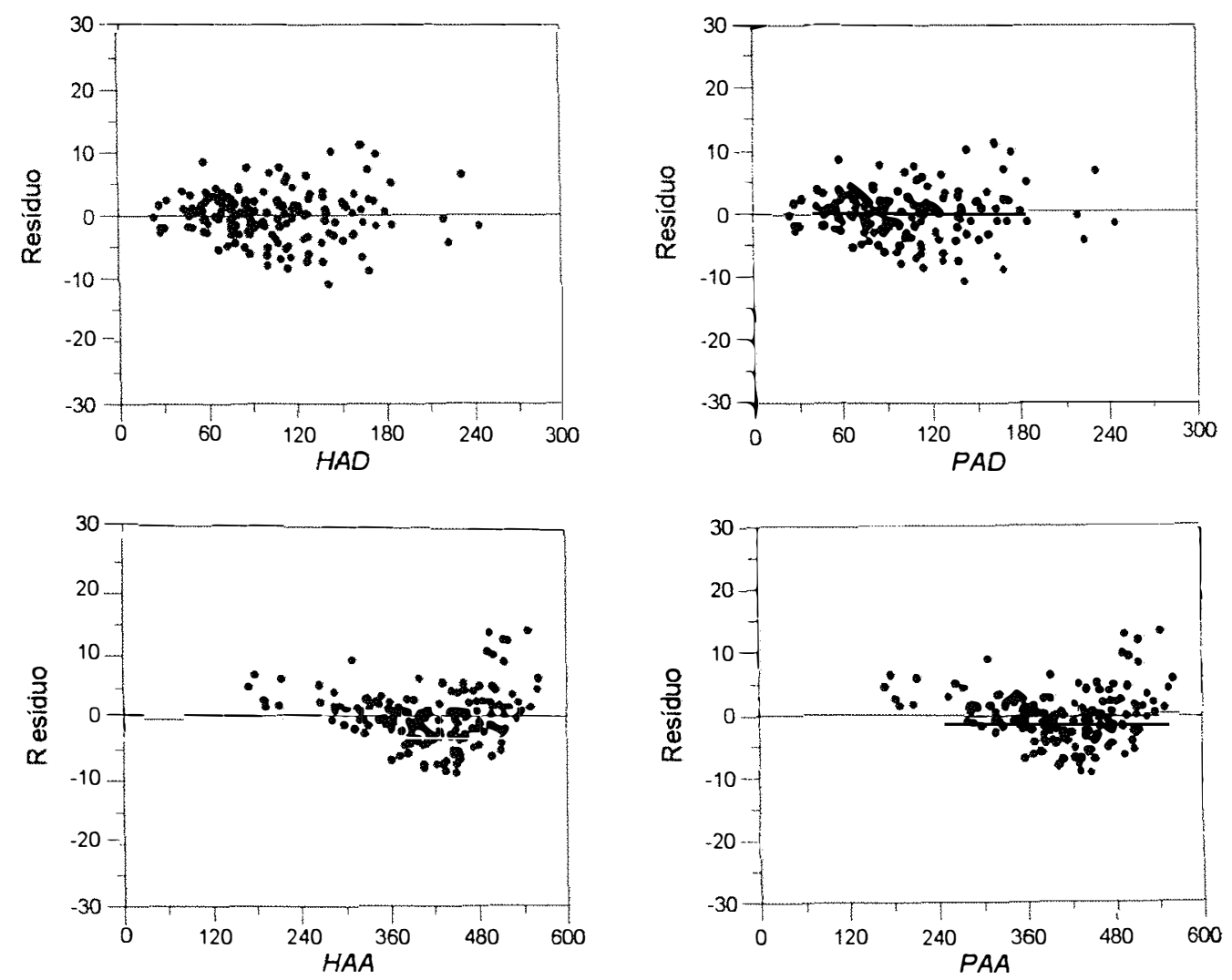

Figura 11. Distribuição dos resíduos (valor observado - valor previsto da produção pela regressão linear) em função das variáveis independentes $H A D$ (dias), $P A D$ (dias), $H A A\left(\mathrm{MJ} \mathrm{m}^{-2}\right)$ e $P A A\left(\mathrm{MJ} \mathrm{m}^{-2}\right)$ no experimento F-II com ferrugem (Iamauti, 1995). 

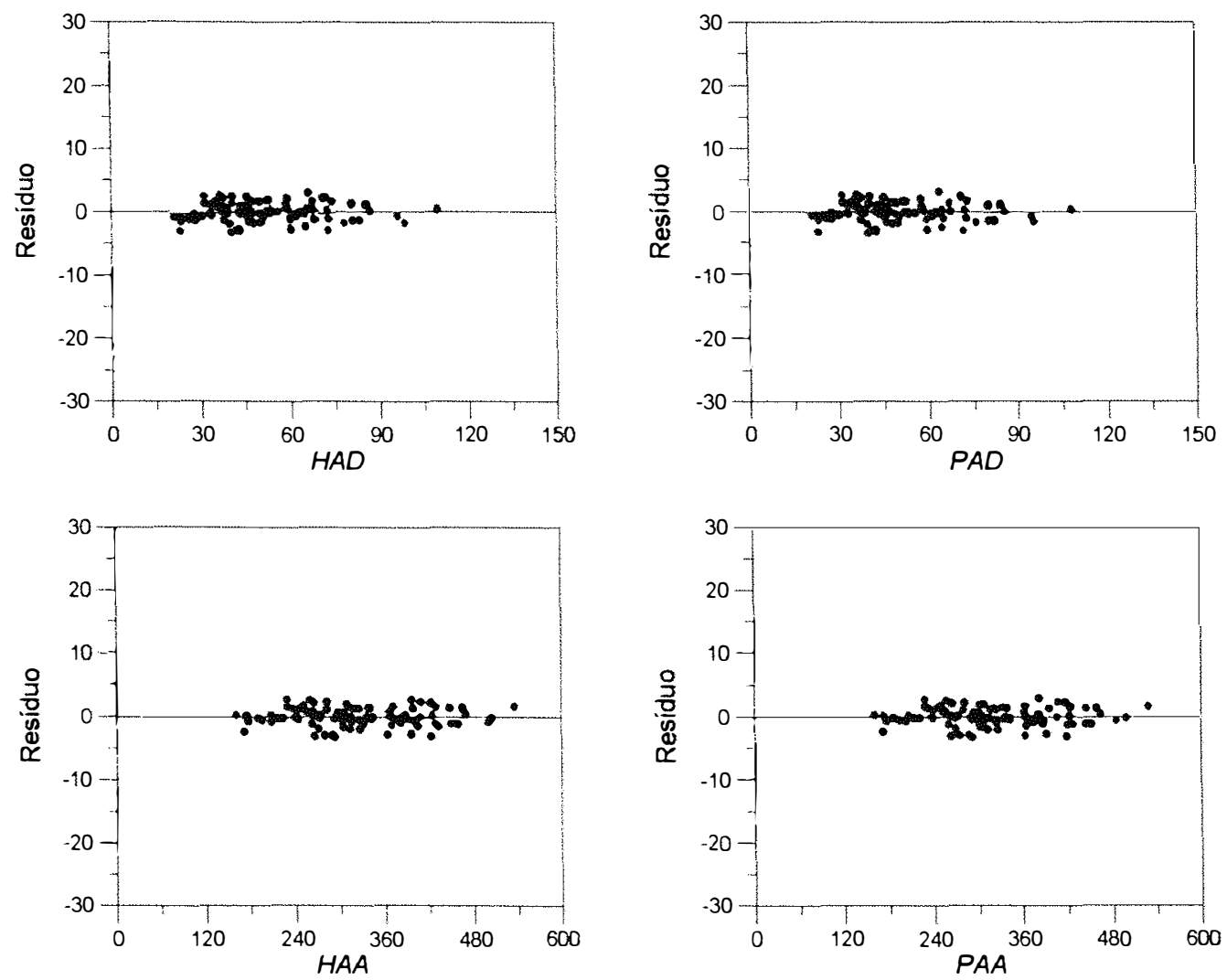

Figura 12. Distribuição dos residuos (valor observado - valor previsto da produção pela regressão linear) em função das variáveis independentes $H A D$ (dias), $P A D$ (dias), $H A A\left(\mathrm{MJ} \mathrm{m}^{-2}\right)$ e $P A A\left(\mathrm{MJ} \mathrm{m}^{-2}\right)$ no experimento M-I com mancha angular (Carneiro, 1995). 

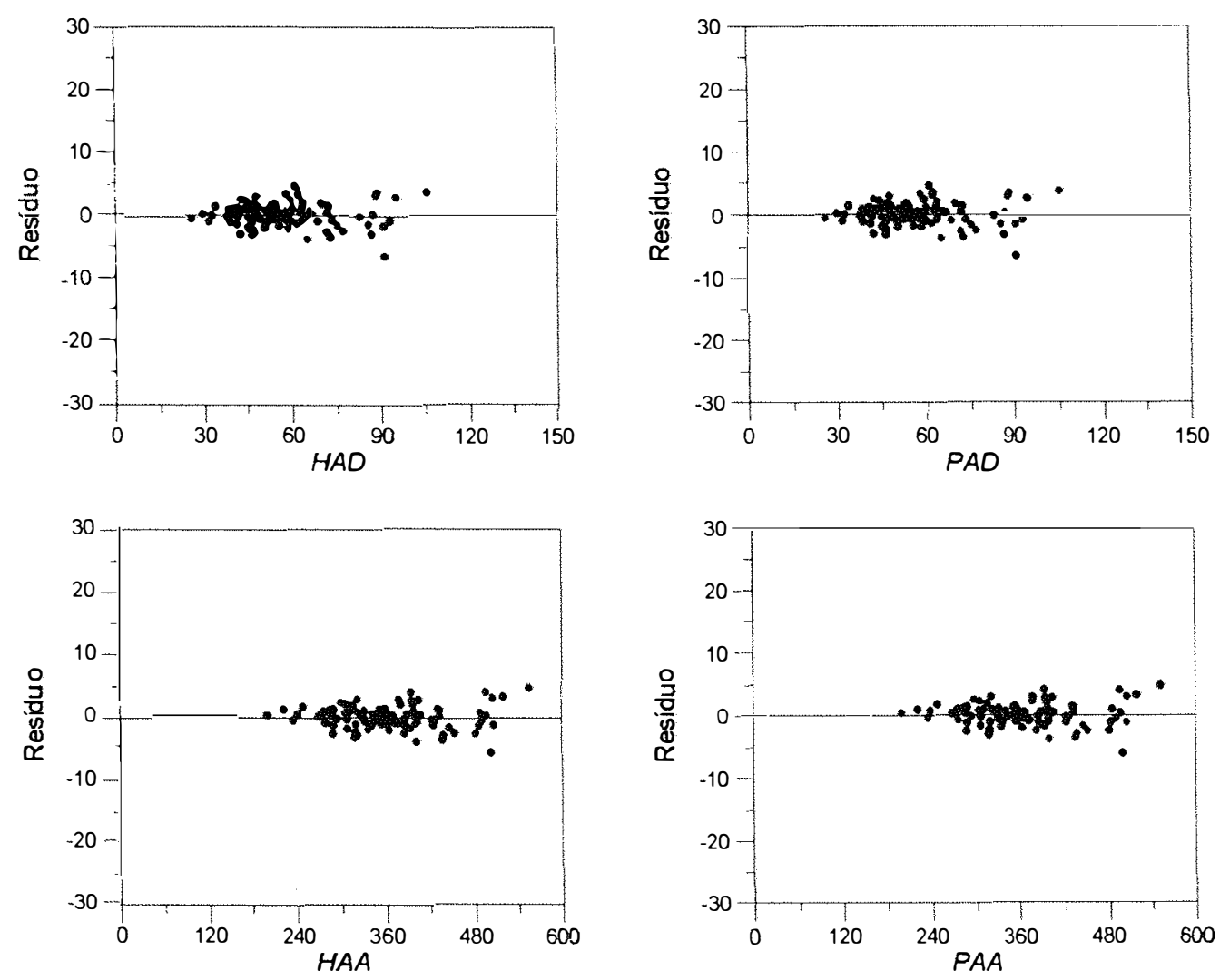

Figura 13. Distribuição dos resíduos (valor observado - valor previsto da produção pela regressão linear) em função das variáveis independentes $H A D$ (dias), $P A D$ (dias), HAA ( $\left.\mathrm{MJ} \mathrm{m}^{-2}\right)$ e PAA $\left(\mathrm{MJ} \mathrm{m}^{-2}\right)$ no experimento M-II com mancha angular (Carneiro, 1995). 

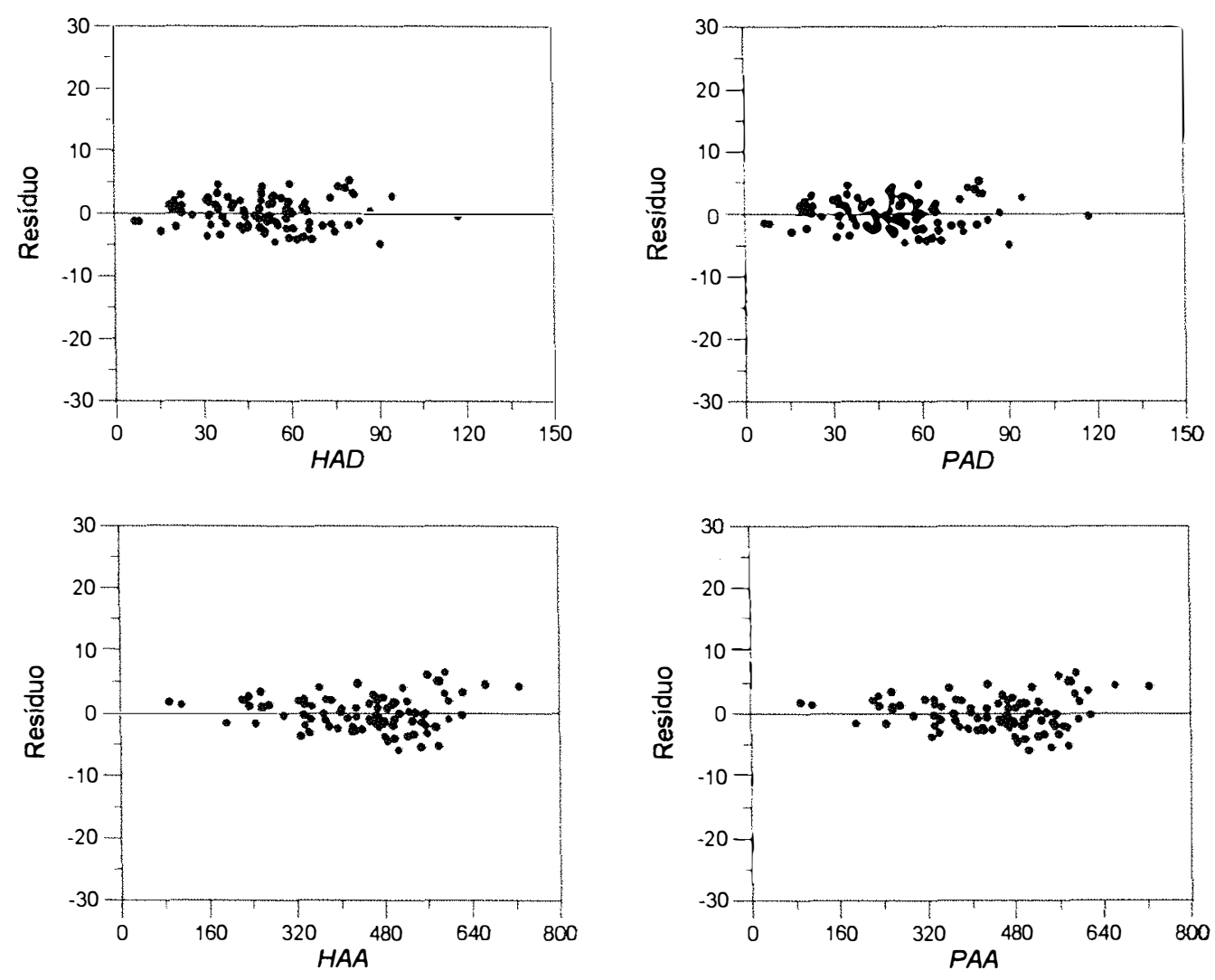

Figura 14. Distribuição dos resíduos (valor observado - valor previsto da produção pela regressão linear) em função das variáveis independentes $H A D$ (dias), $P A D$ (dias), HAA ( $\left.\mathrm{MJ} \mathrm{m}^{-2}\right)$ e PAA ( $\left.\mathrm{MJ} \mathrm{m}^{-2}\right)$ no experimento $\mathrm{M}$-III com mancha angular (Carneiro, 1995). 

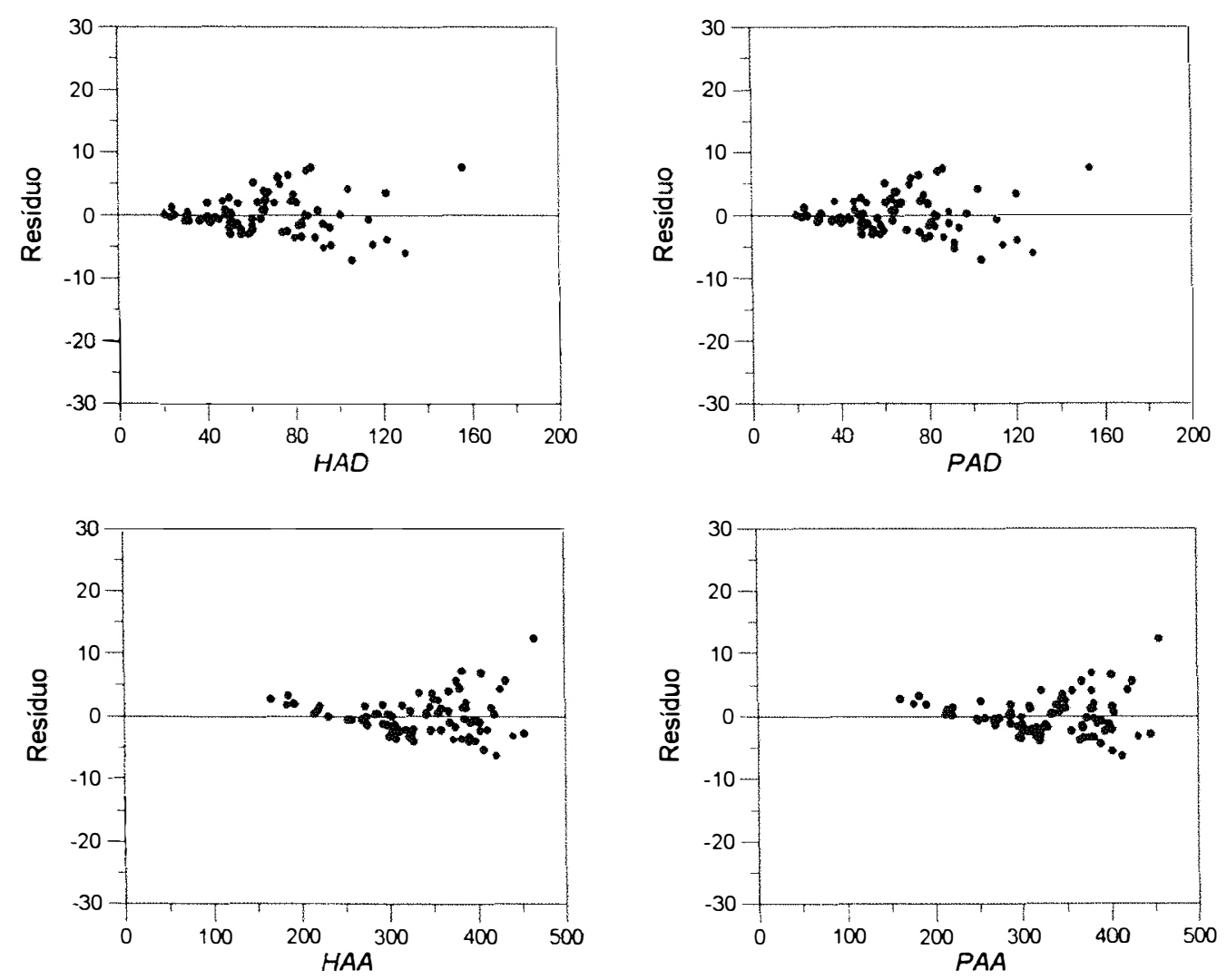

Figura 15. Distribuição dos resíduos (valor observado - valor previsto da produção pela regressão linear) em função das variáveis independentes $H A D$ (dias), $P A D$ (dias), HAA (MJ m $\left.{ }^{-2}\right)$ e $P A A\left(\mathrm{MJ} \mathrm{m}^{-2}\right)$ no experimento M-IV com mancha angular (Godoy, 1995). 

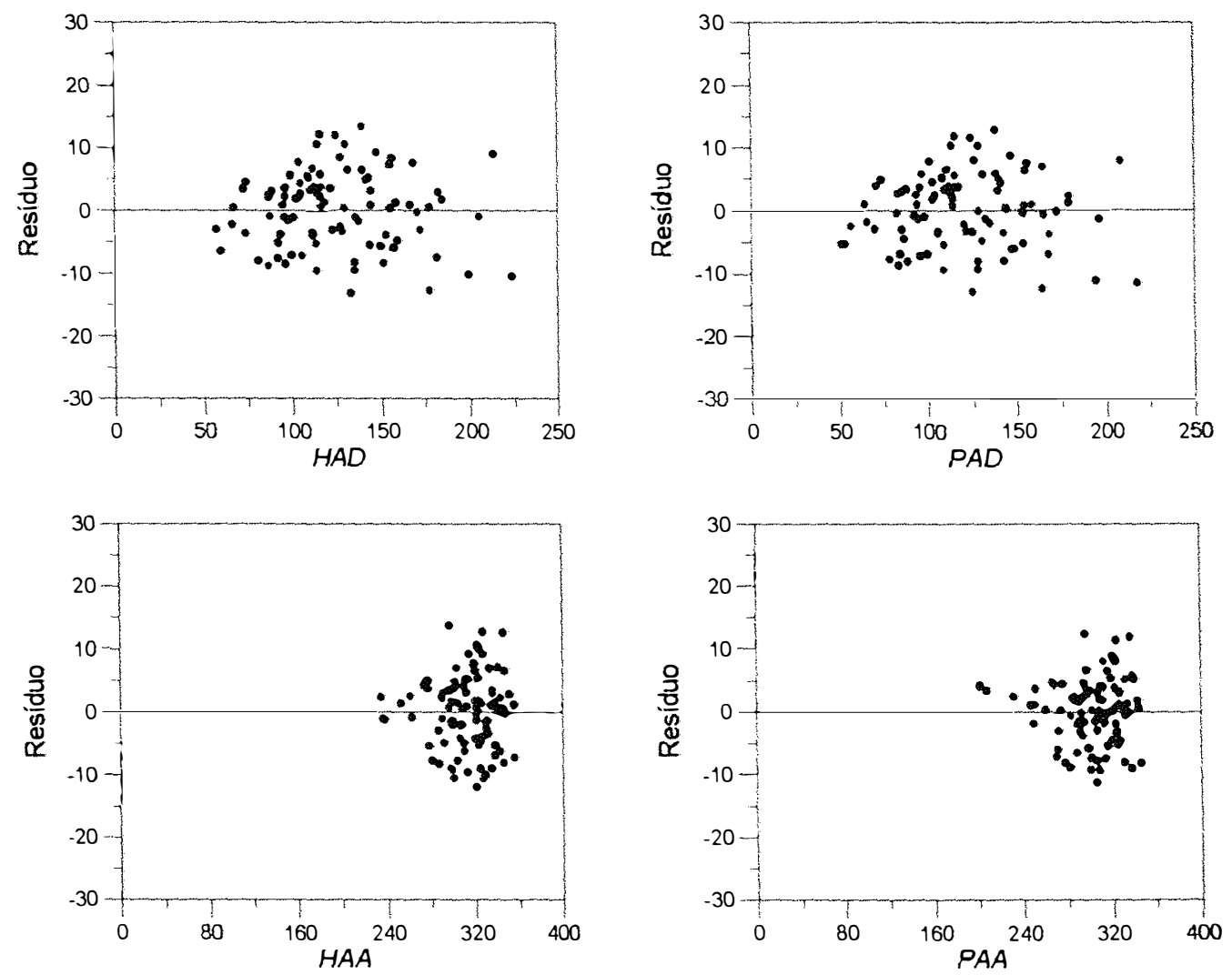

Figura 16. Distribuição dos resíduos (valor observado - valor previsto da produção pela regressão linear) em função das variáveis independentes $H A D$ (dias), $P A D$ (dias), HAA ( $\left.\mathrm{MJ} \mathrm{m}^{-2}\right)$ e $P A A\left(\mathrm{MJ} \mathrm{m}^{-2}\right)$ no experimento $\mathrm{M}-\mathrm{V}$ com mancha angular (Godoy, 1995). 

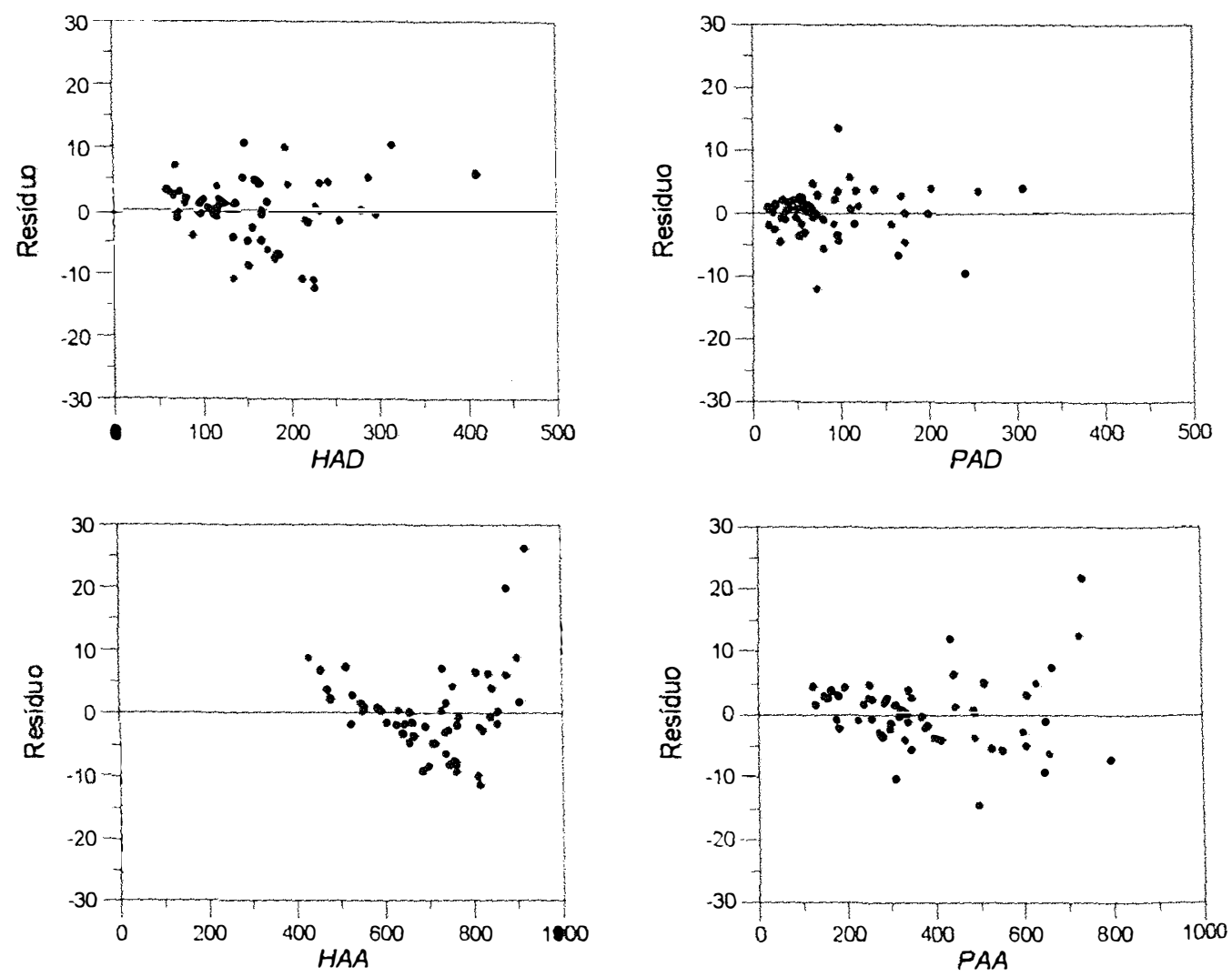

Figura 17. Distribuição dos resíduos (valor observado - valor previsto da produção pela regressão linear) em função das variáveis independentes $H A D$ (dias), $P A D$ (dias), HAA $\left(\mathrm{MJ} \mathrm{m}^{-2}\right)$ e $P A A\left(\mathrm{MJ} \mathrm{m}^{-2}\right)$ no experimento A-I com antracnose (Gianasi, 1999) 

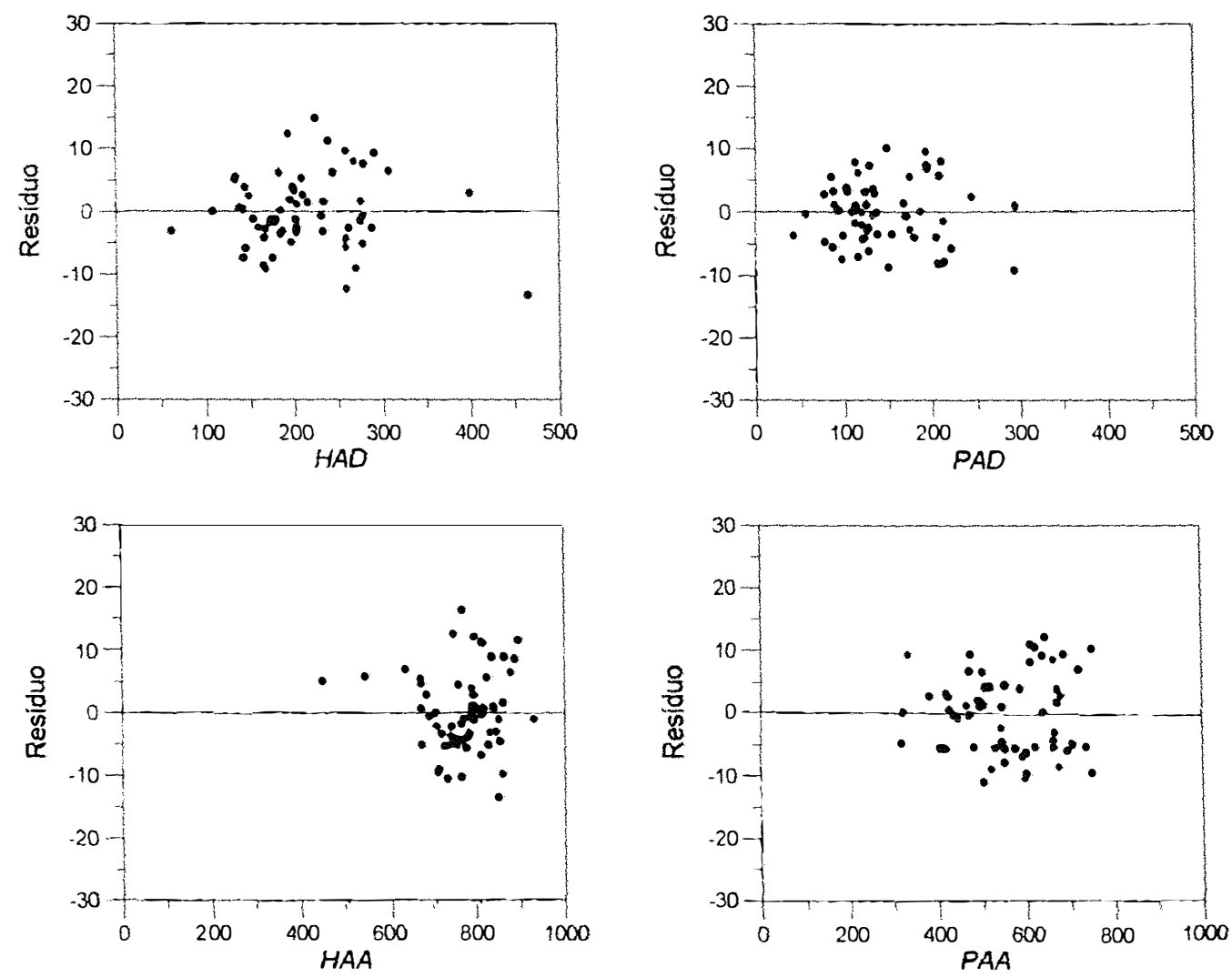

Figura 18. Distribuição dos resíduos (valor observado - valor previsto da produção pela regressão linear) em função das variáveis independentes $H A D$ (dias), $P A D$ (dias), HAA ( $\left.\mathrm{MJ} \mathrm{m}^{-2}\right)$ e $P A A\left(\mathrm{MJ} \mathrm{m}^{-2}\right)$ no experimento A-II com antracnose (Gianasi, 1999). 